MÓNICA MARCELA CASTIBLANCO VALENCIA

\title{
INTERAÇÃO DE PROTEÍNAS DE MEMBRANA DE LEPTOSPIRA COM OS REGULADORES FATOR H E C4BP DO SISTEMA COMPLEMENTO HUMANO
}

Tese apresentada ao Programa de Pós-Graduação em Imunologia do Instituto de Ciências Biomédicas da Universidade de São Paulo, para obtenção do Título de Doutor em Ciências. 


\section{INTERAÇÃO DE PROTEÍNAS DE MEMBRANA DE LEPTOSPIRA COM OS REGULADORES FATOR H E C4BP DO SISTEMA COMPLEMENTO HUMANO}

Tese apresentada ao Programa de Pós-Graduação em Imunologia do Instituto de Ciências Biomédicas da Universidade de São Paulo, para obtenção do Título de Doutor em Ciências.

Área de concentração: Imunologia

Orientadora: Profa. Dra. Lourdes Isaac

Co-orientadora: Profa. Dra. Angela Silva Barbosa

Versão original 
DADOS DE CATALOGAÇÃO NA PUBLICAÇÃO (CIP)

Serviço de Biblioteca e Informação Biomédica do

Instituto de Ciências Biomédicas da Universidade de São Paulo

reprodução não autorizada pelo autor

Valencia, Mónica Marcela Castiblanco.

Interação de proteínas de membrana de Leptospira com os

reguladores Fator $\mathrm{H}$ e C4BP do sistema complemento humano / Mónica Marcela Castiblanco Valencia. -- São Paulo, 2014.

Orientador: Profa. Dra. Lourdes Isaac.

Tese (Doutorado) - Universidade de São Paulo. Instituto de Ciências Biomédicas. Departamento de Imunologia. Área de concentração: Imunologia. Linha de pesquisa: Sistema complemento.

Versão do título para o inglês: Interaction of Leptospira membrane proteins with human complement regulators Factor $\mathrm{H}$ and C4BP.

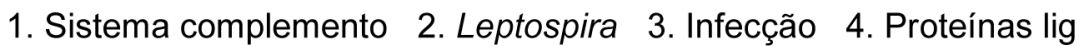
5. Fator H 6. C4BP I. Isaac, Profa. Dra. Lourdes II. Universidade de São Paulo. Instituto de Ciências Biomédicas. Programa de Pós-

Graduação em Imunologia III. Título. 


\section{UNIVERSIDADE DE SÃO PAULO INSTITUTO DE CIÊNCIAS BIOMÉDICAS}

$\begin{array}{ll}\text { Candidato(a): } & \text { Mónica Marcela Castiblanco Valencia. } \\ \text { Título da Tese: } & \begin{array}{l}\text { Interação de proteinas de membrana de Leptospira com os } \\ \text { reguladores Fator H e C4BP do sistema complemento humano. }\end{array}\end{array}$

Orientador(a): $\quad$ Profa. Dra. Lourdes Isaac.

A Comissão Julgadora dos trabalhos de Defesa da Tese de Doutorado, em sessão pública realizada a I.. , considerou
( ) Aprovado(a)
( ) Reprovado(a)

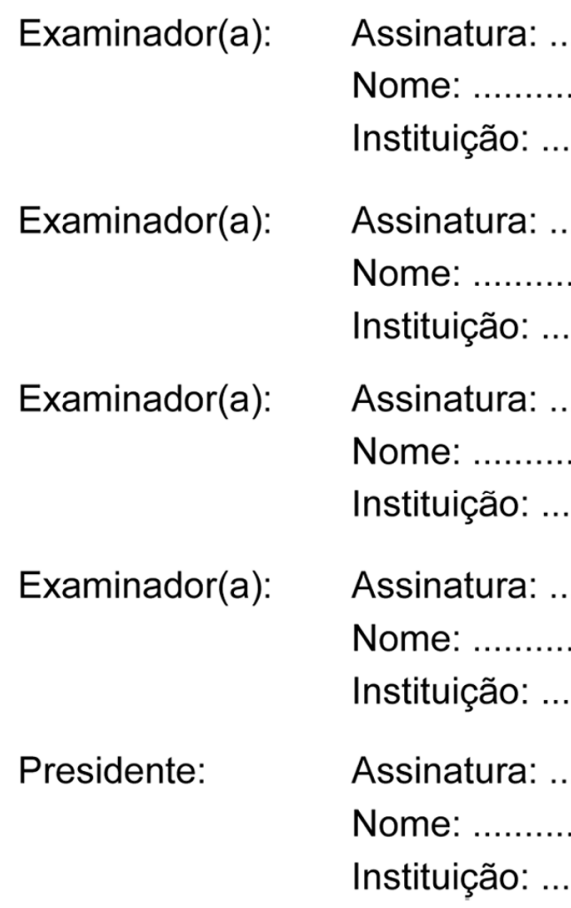




\section{APROVAÇÃO DO COMITE DE ÉTICA}

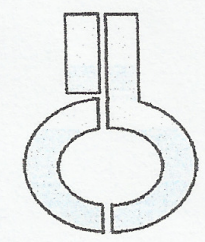

UNIVERSIDADE DE SÃO PAULO

INSTITUTO DE CIÊNCIAS BIOMÉDICAS

Cidade Universitária "Amando de Salles Oliveira"

Av. Prof. Lineu Prestes, 2415 - cep. 05508 -000 Săo Paulo, SP - Brasil

Telefone :(55) (11) 3091.7733 telefax : (55) (11) 3091-7438

e-mail: cep@ icb.usp.br

\section{PARECER $86 \% / C E P$}

Söo Paulo, 17 de novembro de 2008.

Prezada Senhora,

Atendendo sua solicitação, a Comissão de Ética em Pesquisas com Seres Humanos do ICB, em sua $89^{\circ}$ reunião realizada em 24.10 .08 , analisou o projeto de sua responsabilidade intitulado: "Interação de proteínas de membrana de Leptospira com os reguladores Fator H e C4BP do sistema complemento humano".

informo a V.Sa. que, após análise e discussão, o referido projeto foi aprovado por esta Comissc̃o.

Lembramos que cabe ao pesquisador elaborar e apresentar a este Comitê, relatórios anuais (parciais ou final), de acordo com a resolução 196/06 do Conselho Nacional da Saúde, ifem X.2 letra C.

o primeiro relatório deverá ser encaminhado à Secretaria deste CEP em 24 de outubro de $200 \%$.

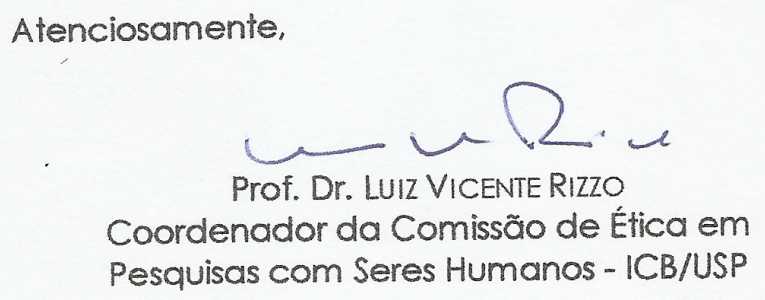

IIma. Sra.

mónica marcela castiblanco Valencia

Departamento de Imunologia

Instituto de Ciências Biomédicas -USP 


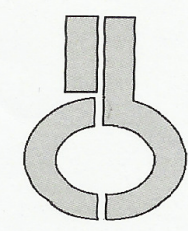

UNIVERSIDADE DE SÃO PAULO INSTITUTO DE CIÊNCIAS BIOMÉDICAS

Cidade Universitária "Armando de Salles Oliveira"

Av. Prof. Lineu Prestes, 2415 - CEP. 05508-000 São Paulo, SP - Brasi

Telefone :(55) (011) 3091.7733 - telefax : (55) (011) 3091.7438

e-mail: cep@icb.usp.br

\section{Certificado}

Certificamos que o protocolo registrado sob $n^{\circ} 99$ nas fls. 61 do livro 02 para uso de animais em experimentação, sob a responsabilidade de Lourdes Isaac, Coordenador(a) da Linha de pesquisa "Interação de proteinas de membrana de leptospira com os reguladores Fator $H$ e C4BP do sistema complemento humano" do qual participou(aram) o(s) Monica Marcela Castiblanco Valencia e os pesquisadores Ângela Silva Barbosa, Patricia Antonia Estima Abreu, Paulo Lee Ho está de acordo com os Princípios Éticos de Experimentação Animal adotado pelo Colégio Brasileiro de Experimentação Animal (COBEA) e foi aprovado pela COMISSÃO DE ÉTICA EM EXPERIMENTAÇÃO ANIMAL (CEEA) em 27.11.08, com validade de 3 anos.

São Paulo, 28 de novembro de 2008.

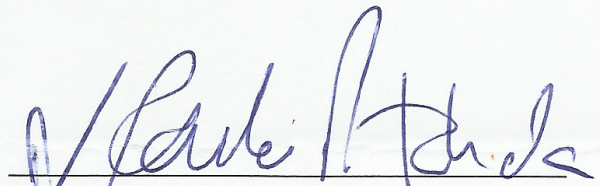

Prof. Dr. Wothan Tavares DE Lima

Coordenador CEEA - ICB/USP

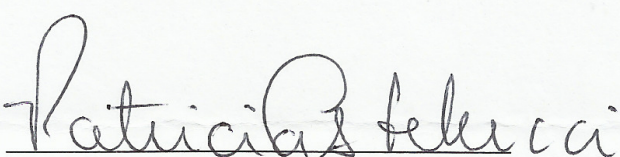

Profa. Dra. PATRÍCIA CASTELUCCI

Secretária CEEA - ICB/USP 
Dedico este trabalho a minha mãe Martha, obrigada pelo amor e apoio incondicional, pelos sábios conselhos e por ser meu maior exemplo de força, coragem, abnegação e perseverança. 


\section{AGRADECIMENTOS}

À minha amada família, meus pais Martha e Luis, meus irmãos Diana e Cristhian. Obrigada pelo amor incondicional, pelo apoio, pela compreensão dedicação, por entenderam minha ausência durante estes anos e principalmente por me incentivarem sempre a correr atrás dos meus sonhos com esforço e determinação.

À meu namorado e amigo Darwin; por me incentivar a seguir enfrente com decisão e coragem, pela paciência, pelos conselhos e por me fazer acreditar que eu conseguiria chegar ao final desta difícil, porém gratificante etapa.

À minha orientadora Dra. Lourdes Isaac por ter me recebido no seu laboratório, por ter me dado a oportunidade de construir um sonho e de conhecer o encantador mundo da Imunologia. Muito obrigada, pelo carinho, pela dedicação, pela paciência, pelos conselhos, por se alegrar com minhas conquistas, por me mostrar o caminho da ciência e por incentivar meu pensamento critico.

À minha co-orientadora Dra. Angela Barbosa por ter me apresentado as leptospiras, pelo carinho, pela dedicação, pela paciência, porque nunca mediu esforços para me ajudar. Pelas longas conversas sobre os resultados e experimentos.

À minha querida amiga Adriana (minha irmã aqui em Brasil), juntas embarcamos nesta aventura e descobrimos o fascino deste novo mundo, agradeço o carinho, a motivação, a ajuda o sorriso afetuoso e a companhia durante estes anos.

À Tati pelo carinho, pela ajuda, por todos os bons momentos. Agradeço por ter encontrado em você uma grande amiga.

Aos meus ex-colegas de laboratório: Lorena, Jose Antonio, Renan, Alda e Isabel, obrigada por me acolher na minha chegada ao laboratório, aprendí muito com vocês.

Aos meus colegas de Laboratório: Adriana, Tati, Karina, Leandro, Iris, Marlene, Daniella, Pietro, Andre, Thais, Denise e Prisilla. Obrigada pelo bom humor, por tornar 
agradável nosso ambiente de trabalho, pela ajuda, pelos os incentivos e pelas longas discussões de resultados. Vocês serão sempre muito especiais para mim.

À Ludmila, Denize, Ligia, Lidia, Demetria, a Dra. Patrícia Abreu Estima e a todas as pessoas do laboratório de bacteriologia do Instituto Butantan, muito obrigada por toda a ajuda prestada ao longo do meu doutorado.

À Nuria, Tiago, María, Celia pela amizade, carinho e apoio.

Ao Dr. Sílvio de Arruda Vasconcellos e Zenaide, pelo fornecimento das leptospiras $L$. biflexa e L. interrogans utilizadas neste estudo.

Ao Dr. Claúdio Pereira Figueira da Fundação Oswaldo Cruz, Salvador, Brazil e o Dr. Albert Ko da Universidade de Yale, Estados Unidos pelo fornecimento das cepas de L. biflexa transgênicas para LigA e LigB.

Ao Dr. Mihaly Jószi, pesquisador do Leibniz Institute for Natural Product Research and Infection Biology-Hans Knöll Institute, Jena, Alemanha pelo fornecimento das proteínas recombinantes FHL-1, FHR-1 e os domínios de FH.

Aos funcionários e Professores do Departamento de Imunologia, pela ajuda, pelas aulas e conhecimentos transmitidos.

À Fapesp pelo incentivo e suporte financeiro fornecido durante toda a execução do projeto.

À CAPES pelo suporte financeiro fornecido no início do meu doutorado. 


\section{RESUMO}

Castiblanco-Valencia MM. Interação de proteínas de membrana de leptospira com os reguladores Fator $\mathrm{H}$ e $\mathrm{C} 4 \mathrm{BP}$ do sistema complemento humano. [tese (Doutorado em Imunologia)]. São Paulo: Instituto de Ciências Biomédicas, Universidade de São Paulo; 2014.

A capacidade da Leptospira de escapar do sistema complemento é fundamental para a infecção seja bem sucedida. Esta hipótese é apoiada por resultados in vitro que demonstram que espécies saprófitas de leptospira morrem em poucos minutos na presença de soro humano normal, enquanto espécies patogênicas são capazes de sobreviver por longos períodos de tempo. Diferentes mecanismos envolvidos na evasão das leptospiras da morte mediada pelo complemento têm sido descritos, como a ligação a reguladores negativos do sistema complemento e a proteínas da cascata de coagulação, além da secreção de proteases capazes de interromper a ativação do sistema complemento. Neste estudo demonstramos que a aquisição do Fator H (FH) pela leptospira é crucial para a sobrevivência das bactérias no soro. A ligação de leptospiras a estes reguladores do complemento é mediada pelas proteínas leptospiral immunoglobulin-like (Lig) A e LigB, proteínas presentes somente em espécies patogênicas. FH se liga às proteínas Lig principalmente pelos short consensus repeat 5 e 20. Ensaios de competição sugerem que FH e C4BP interagem com sítios de ligação diferentes nas proteínas Lig. Ambas as proteínas reguladoras FH e C4BP mantêm atividade de co-fator, quando ligadas às Ligs, mediando a degradação de $\mathrm{C} 3 \mathrm{~b}$ e $\mathrm{C} 4 \mathrm{~b}$ pelo Fator I (FI). Para determinar o papel específico destas proteínas na evasão ao complemento foram utilizadas leptospiras transgênicas $L$. biflexa sorovar Patoc expressando as proteínas LigA ou LigB de $L$. interrogans. Demonstramos que a aquisição de FH e C4BP pelas leptospiras transgênicas que expressam LigA e LigB exerce um papel protetor, sendo crucial para a sobrevida destas bactérias. Verificamos também que tanto FH como C4BP mantêm a atividade de co-fator, sugerindo que a aquisição destes reguladores na membrana bacteriana pode contribuir para a resistência à morte mediada pelo sistema complemento. Análises por citometria de fluxo confirmaram a capacidade da L. biflexa expressando LigA e LigB para controlar a deposição de $\mathrm{C} 3, \mathrm{C} 4$ e do complexo de ataque à membrana, aumentando sua sobrevida no soro. Outra estratégia utilizada pelos patógenos é a aquisição de plasminogênio e a sua conversão em plasmina, a qual é capaz de clivar os componentes do complemento C3b e C5 na superfície do patógeno. Demonstramos que as proteínas Lig foram capazes de se ligar a plasminogênio, o qual foi ativado em plasmina pela adição do ativador de plasminogênio tipo uroquinase (uPA). Além de degradar fibrinogênio, essa plasmina ativa foi capaz de degradar C3b e C5, inativando essas proteínas e bloqueando assim as três vias do complemento. Em conclusão, demonstramos que a expressão heteróloga de LigA e LigB em L. biflexa foi capaz de conferir proteção contra a morte mediada pelo complemento. As proteínas Lig são moléculas multifuncionais que contribuem para a adesão e evasão imune, sendo a identificação desses ligantes em leptospiras de grande relevância, uma vez que podem representar alvos de interferência na resposta imunológica.

Palavras-chave: Sistema Complemento. Leptospira. Evasão Imune. Proteínas Lig. Fator H. C4BP. 


\begin{abstract}
Castiblanco-Valencia MM. Interaction of Leptospira membrane proteins with human complement regulators Factor $\mathrm{H}$ and C4BP. [Ph. D. thesis (Immunology)]. São Paulo: Instituto de Ciências Biomédicas, Universidade de São Paulo; 2014.

The ability of Leptospira to evade the complement system is crucial for a successful infection. This assumption is supported by in vitro results demonstrating that saprophytic leptospiral strains are killed within a few minutes in the presence of normal human serum whereas pathogenic ones are able to survive for much longer periods of time. Different mechanisms have been shown to be involved in evasion of complement-mediated killing such as binding to negative complement regulators, coagulation cascade proteins and the secretion of proteases. In this study, we demonstrate that acquisition of Factor $\mathrm{H}(\mathrm{FH})$ on the Leptospira surface is crucial for bacterial survival in the serum and that these spirochetes, besides interacting with FH, FHR-1 and C4BP, also acquire FHL-1 from human serum. We also demonstrate that binding to these complement regulators is mediated by leptospiral immunoglobulin-like (Lig) proteins, proteins that are present only in pathogenic but not in saprophytic species. FH binds to Lig proteins via short consensus repeat 5 and 20. Competition assays suggest that $\mathrm{FH}$ and $\mathrm{C} 4 \mathrm{BP}$ have distinct binding sites on Lig proteins. Moreover, FH and C4BP bound to immobilized Ligs display cofactor activity, mediating $\mathrm{C} 3 \mathrm{~b}$ and $\mathrm{C} 4 \mathrm{~b}$ degradation by Factor I (FI). Here we also used the saprophyte $L$. biflexa serovar Patoc expressing L. interrogans LigA ou LigB proteins to determine the specific role of Lig proteins in complement evasion. We demonstrated that acquisition of $\mathrm{FH}$ and $\mathrm{C} 4 \mathrm{BP}$ by the LigA and LigB transformed L. biflexa but not L. biflexa have the protective role, being crucial by bacterial survival. We also found that both FH and C4BP maintain the co-factor activity indicating that acquisition of complement regulators in the surface membrane may contribute to the leptospiral serum resistance. Analysis by cytometer flow also confirmed the ability of L. biflexa expressing LigA and $\mathrm{LiB}$ to control the deposition of $\mathrm{C} 3, \mathrm{C} 4$ and MAC increasing the possibilities of survival in the serum. In conclusion, we have demonstrated that the heterologous expression of ligA and $\operatorname{lig} B$ in L. biflexa was able to confer protection against complement system attack. Another strategy employed by pathogens is the acquisition of plasminogen and its conversion to plasmin, which is able to cleave the complement components $\mathrm{C} 3 \mathrm{~b}$ and $\mathrm{C} 5$ on the pathogen's surface. We demonstrate that the Lig proteins were able to bind plasminogen, which was activated to plasmin by addition of human urokinase type plasminogen activator (UPA). We also show that plasminogen bound to Lig proteins was converted to active plasmin and this enzyme was able to degrade the fibrinogen, $\mathrm{C} 3 \mathrm{~b}$ and $\mathrm{C} 5$. These cleavages inactivate $\mathrm{C} 3 \mathrm{~b}$ and $\mathrm{C} 5$, preventing progression of the complement cascade and blocking the three complement pathways. The identification of these leptospiral ligands is of great relevance since they may represent targets for immune interference. We conclude that Lig proteins are multifunctional molecules that contribute to leptospiral adhesion and immune evasion.
\end{abstract}

Keywords: Complement system. Leptospira. Immune evasion. Lig proteins. Factor H. C4BP. 


\section{LISTA DE ILUSTRAÇÕES}

Figura 1 - Natureza bifásica da leptospirose e aspectos relevantes em diferentes estágios da

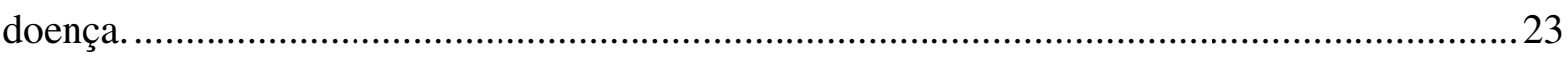

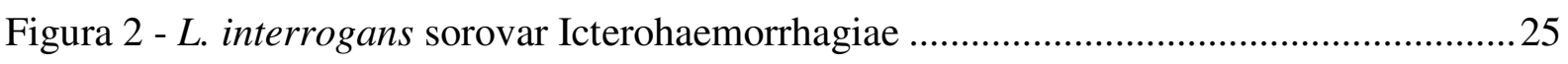

Figura 3 - Representação esquemática da arquitetura da membrana de Leptospira.................26

Figura 4 - Ativação do Sistema de Complemento.................................................................. 31

Figura 5 - Inibição da ativação da via alternativa por FH. ......................................................32

Figura 6 - Inibição da via clássica ou das lectinas por C4BP.................................................33

Figura 7 - Representação dos domínios SCRs que compõem as proteínas da família do FH..35 Figura 8 - Representação esquemática de C4BP indicando seus sítios de interação com

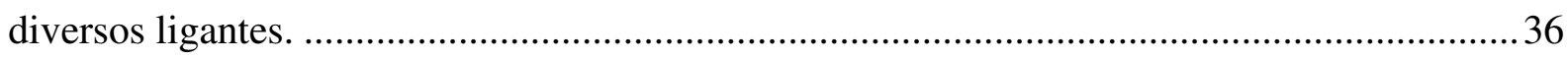

Figura 9 - Sistema fibrinolítico e sua utilização por bactérias. ............................................... 37

Figura 10 - Representação da estrutura do plasminogênio humano..........................................38

Figura 11 - Plasminogênio controla as vias de ativação do sistema complemento em

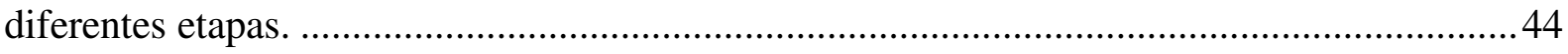

Figura 12 - Representação do vetor $p$ GEM-T Easy (Promega). .............................................49

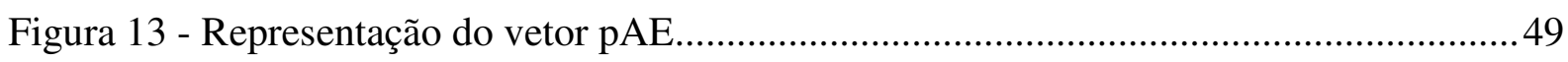

Figura 14 - Representação esquemática das proteínas Ligs ...................................................68

Figura 15 - Amplificação dos fragmentos gênicos por PCR …..............................................69

Figura 16 - Análise dos plasmídeos pGEM-T contendo os insertos LigAC, LigBC ou LigBN

Figura 17 - Análise dos plasmídeos contendo o inserto 70

Figura 18 - Análise da expressão das proteínas LigAC, LigBC e LigBN por SDS-PAGE 12\%

Figura 19 - Análise por SDS-PAGE da purificação por cromatografia de afinidade das

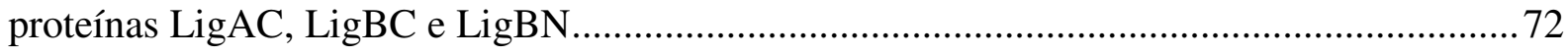

Figura 20 - Determinação da concentração de LigBC por densitometria óptica.......................73

Figura 21 - Determinação do titulo de anticorpos de camundongos imunizados com as proteínas recombinantes $\operatorname{LigAC}, \operatorname{LigBC}$ e LigBN ............................................................ 74

Figura 22 - Interação de L. interrogans com FH, FHL-1 e FHR-1 ........................................ 75

Figura 23 - Análise da interação de FH com as proteínas recombinantes de Leptospira por

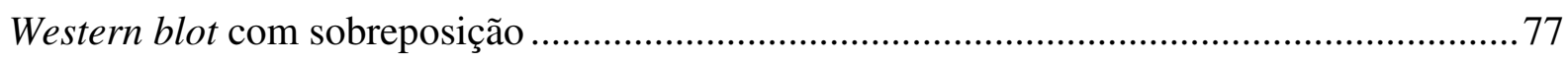

Figura 24 - Análise da interação das proteínas Ligs com C4BP ........................................... 77 
Figura 25 - Análise da interação das proteínas Lig com os reguladores do complemento FH e C4BP por ELISA

Figura 26 - Análise da atividade do FH como co-fator de FI na clivagem de C3b 80

Figura 27 - Análise da atividade do FH ligado a proteínas recombinantes LIC11087 e LIC10657 como co-fator de FI na clivagem de C3b

Figura 28 - Análise da atividade de C4BP como co-fator de FI na clivagem de C4b..... 82

Figura 29 - Análise da competição entre FH e C4BP por sítios de ligação nas proteínas Ligs83 Figura 30 - Avaliação do efeito protetor do FH na sobrevivência de leptospiras patogênicas 84 Figura 31 - Análise por ELISA da interação das proteínas Lig com os reguladores do complemento FH, FHL-1 FHR-1 e os domínios SCRs 8-14 e 15-20 do FH

Figura 32 - Análise da sobrevivência de leptospiras transgênicas na presença de soro humano normal 88

Figura 33 - Análise da interação de FH e C4BP com leptospiras transgênicas L. biflexa sorovar Patoc expressando ligA e ligB 89

Figura 34 - Análise da atividade de FH como co-fator de FI na clivagem de C3b ..... .91

Figura 35 - Análise da atividade de C4BP como co-fator de FI na clivagem de C4b. 92

Figura 36 - Análise por citometria de fluxo da deposição de C3 em Leptospira 94

Figura 37 - Análise por citometria de fluxo da deposição da C4 em Leptospira 95

Figura 38 - Análise por citometria de fluxo da deposição de MAC em Leptospira 96

Figura 39 - Análise da interação das proteínas recombinantes de L. interrogans com plasminogênio por Western blot com sobreposição .97

Figura 40 - Análise da interação de plasminogênio com as proteínas Lig por ELISA 98

Figura 41 - Interferência de forças iônicas na interação de plasminogênio com as proteínas Lig.

Figura 42 - Caracterização do papel dos resíduos de lisina na interação de plasminogênio com as proteínas Lig. 100

Figura 43 - Atividade da plasmina gerada na presença de proteínas recombinantes de $L$. interrogans

Figura 44 - Clivagem do fibrinogênio pela plasmina gerada após ligação do plasminogênio às proteínas recombinantes de $L$. interrogans 102 Figura 45 - Clivagem do fragmento C3b do complemento humano pela plasmina gerada após ligação do plasminogênio a proteínas recombinantes de L. interrogans. 104 
Figura 46 - Clivagem da proteína C5 do complemento humano pela plasmina gerada após ligação do plasminogênio às proteínas recombinantes de L. interrogans 105 Figura 47 - Análise da competição entre plasminogênio e FH por sítios de ligação nas proteínas Ligs

Figura 48 - Análise da competição entre plasminogênio e C4BP por sítios de ligação nas proteínas Ligs 108

Figura 49 - Separação por citometria de fluxo das populações celulares presentes no sangue. 109

Figura 50 - Análise da sobrevida de L. biflexa e L. interrogans na presença de diferentes quantidades de SHN

Figura 51 - Produção intracelular de espécies reativas de oxigênio (ROS) em PMN coincubados com leptospiras opsonizadas com SHN 112 Figura 52 - Produção intracelular de espécies reativas de oxigênio (ROS) em PMN coincubados com leptospiras opsonizadas com soros humanos depletados de $\mathrm{C} 3, \mathrm{C} 5$ ou de FH

Figura 53 - Produção intracelular de espécies reativas de oxigênio (ROS) em PMN coincubados com leptospiras opsonizadas com diferentes proteínas do complemento 


\section{LISTA DE TABELAS}

Tabela 1 - Nomenclatura das proteínas recombinantes de Leptospira interrogans utilizadas neste estudo, incluindo o número de acesso no Genbank e características gerais.

Tabela 2 - Sequências dos oligonucleotídios

Tabela 3 - Reação de amplificação dos genes por PCR.

Tabela 4 - Condições da PCR (35 ciclos)

Tabela 5 - Enzimas de restrição utilizadas na digestão dos plasmídeos. 


\section{LISTA DE ABREVIATURAS E SIGLAS}

ACA - Ácido aminocapróico

Ag-Ac - Complexo antígeno-anticorpo

Amp - Ampicilina

ANOVA - Análise de variância

Big - Bacterial immunoglobulin-like

C4BP - C4b-binding protein

CRASPs - Complement regulator-acquiring surface proteins

cDNA - DNA complementar

CR3 - Complement receptor type III

DA - Domínio de activação

DC - Domínio catalítico

DHR - dihidrorodamina-123

DO - Densidade óptica

DNA - Ácido desoxirribonucléico

dNTP - Desoxirribonucleotídeo trifosfato

EDTA - Ethylenediamine tetracetic acid

EcoRI - Endonuclease de restrição de Escherichia coli

ECM - Matriz extracelular

ELISA - Enzyme linked immuno sorbent assay

EMJH - Ellinghausen McCullough Johnson and Harris

FB - Fator B

FD - Fator D

FH - Fator H

FHL-1 - Factor H like- protein 1

FHR-1/2/3/4/5 - Factor $H$ related- protein 1/2/3/4/5

FI - Fator I

FITC - Isotiocianato de fluoresceína

h - Hora

$\mathrm{HCl}$ - Ácido clorídrico

HindIII - Endonuclease de restrição de Hemophilus influenzae

IPTG - Isopropil- $\beta$-D-tiogalactopiranosídeo

IgG - Imunoglobulina $\mathrm{G}$ 
IgM - Imunoglobulina M

$\mathrm{kDa}$ - kiloDalton

$\mathrm{kb}$ - kilobase

$\mathrm{kg}$ - Quilograma

LB - Meio Luria-Bertani

LPF - Leptospira interrogans sorovar Kennewicki estirpe Pomona Fromm

LPS - Lipopolissacarídeo

L. biflexa - Leptospira biflexa

L. interrogans - Leptospira interrogans

LcpA - Leptospiral complement regulator-acquiring protein A

LigA - Leptospiral immunoglobulin-like protein A

LigB - Leptospiral immunoglobulin-like protein $\mathrm{B}$

MAC - Complexo de ataque à membrana

MAT - Teste de aglutinação microscópica

MSCRAMMs - Microbial surface components recognizing adhesive matrix molecules

MASP 1/2/3 - Mannose-binding lectin associated serine protease - 1/2/3

MBL - Mannose binding lectin

min - Minutos

mg - Miligrama

$\mathrm{mL}$ - Mililitro

MN - Leucócitos mononucleares

ng - Nanograma

NADPH - Nicotinamide adenine dinucleotide phosphate-oxidase

NLRs - Nod-like receptor

NO - Óxido nítrico

NCBI - National Center for Biotechnology Information

PAI-1 - Inibidor do ativador de plasminogênio tipo 1

PBS - Phosphate buffer saline

PCR - Reação em cadeia da polimerase

PE - R-ficoeritrina

PG - Peptidoglicano

PLA - Plasmina

PLG - Plasminogênio 
ORF - Open Reading Frame

$\mathrm{pb}$ - Pares de bases

PMN - Polimorfonuclear

RBS - Sítio de ligação ao ribossomo

RNA - Ácido ribonucleico

RNAr - Ácido ribonucleico ribossomal

SCR - Short Consensus Repeats

SDS - Dodecil sulfato de sódio

SDS-PAGE - Eletroforese em gel de poliacrilamida contendo SDS

SHN - Soro Humano Normal

SHNi - Soro Humano Normal inativado a $56{ }^{\circ} \mathrm{C}$

SAK - Estafiloquinase

STK - Estreptoquinase

TAE - Tampão Tris-Acetato-EDTA

Taq - DNA polimerase de Thermus aquaticus

Term - terminador de transcrição

TLR-2 - Receptor símile a toll - 2

TLR-4 - receptor símile a toll - 4

tPA - Ativador tecidual de plasminogênio

Tris - Trizma base

U - Unidade de atividade enzimática

uPA - Ativador de plasminogênio tipo uroquinase

WHO - World Health Organization

XGal - 5-bromo-4-cloro-3-indolil- $\beta$-D-galactopiranosídeo

XhoI - Endonuclease de restrição I de Xhantomonas Holcicola

$\mu \mathrm{g}$ - Micrograma

$\mu \mathrm{L}$ - Microlitro

$\mu \mathrm{M}$ - Micromolar

$\mu \mathrm{m}$ - Micrômétro 


\section{SUMÁRIO}

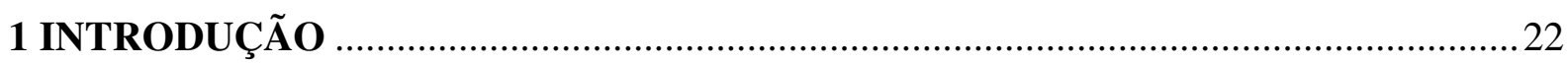

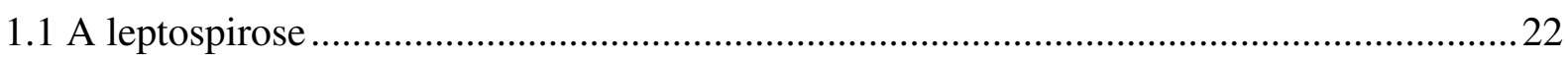

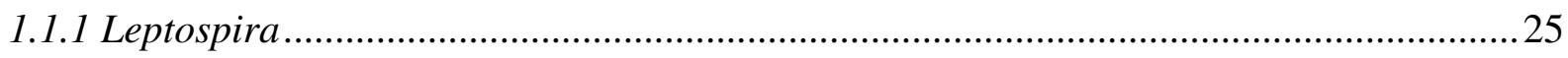

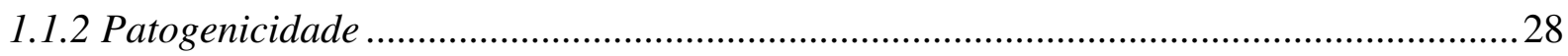

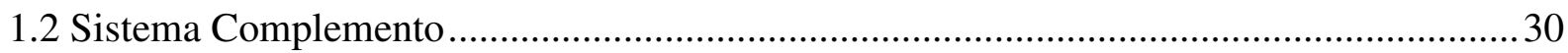

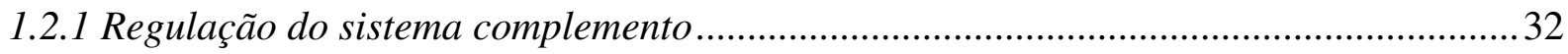



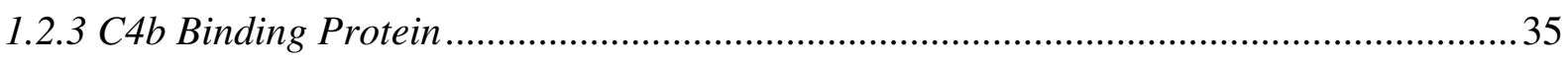

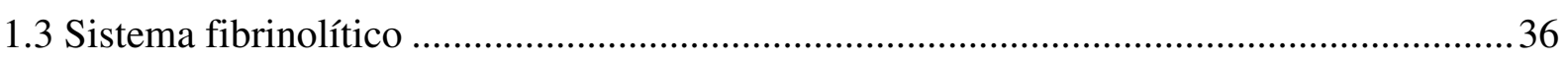

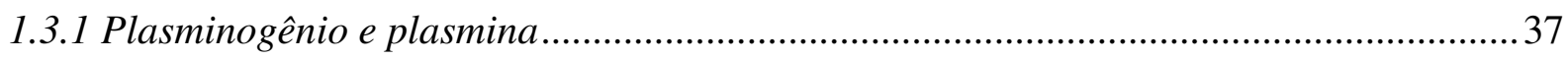

1.3.2 Ativadores do Plasminogênio (APs) .................................................................................... 39

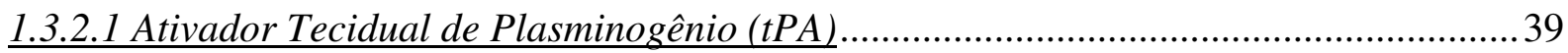

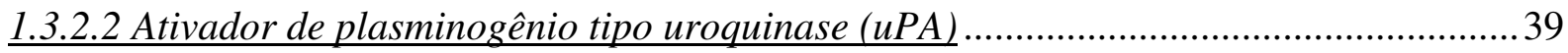

1.3.2.3 Ativadores bacterianos de plasminogênio................................................................... 40

1.3.3 Inibidores dos ativadores de plasminogênio (PAIs) .................................................... 40

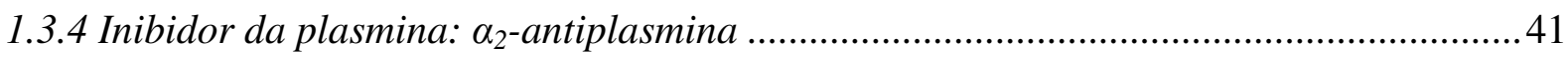

1.4 Sistema Complemento e fibrinólise na eliminação de patógenos ......................................41

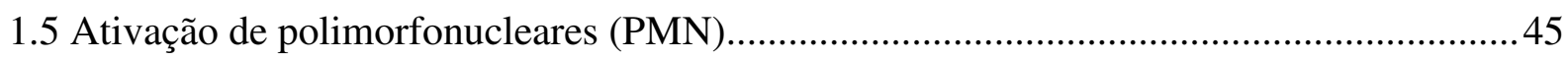

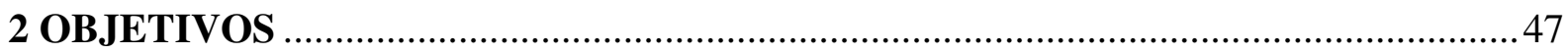

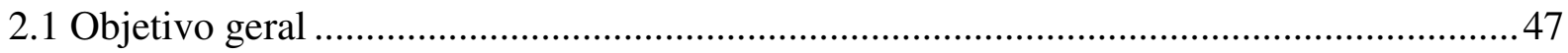

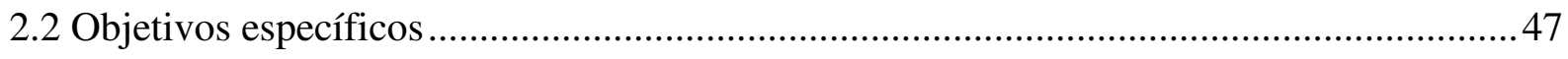

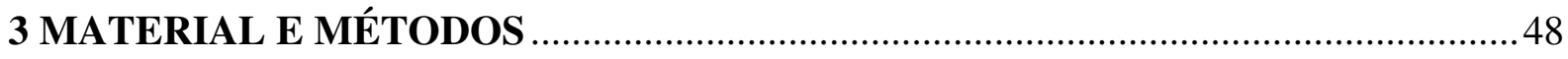

3.1 Seleção das proteínas recombinantes de Leptospira interrogans sorovar Copenhageni.... 48

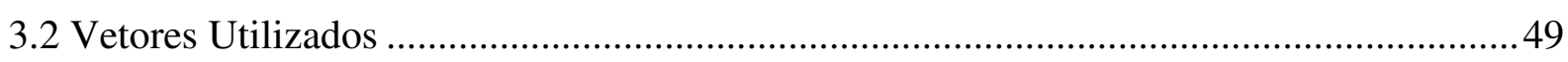

3.3 Linhagens bacterianas empregadas nas clonagens …......................................................50

3.4 Preparação de bactérias competentes .............................................................................50

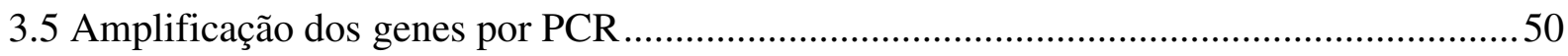

3.7 Clonagem dos insertos no vetor de expressão pAE e transformação de bactérias

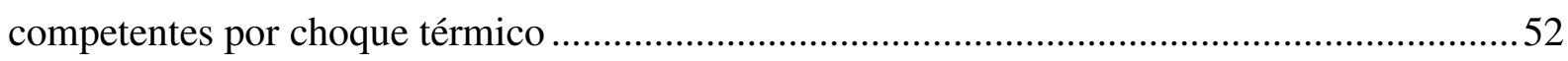

3.12 Determinação da concentração das proteínas purificadas ..............................................55

3.13 Produção de antissoros policlonais contra proteínas recombinantes................................55 
3.14 Determinação do título de anticorpos específicos produzidos contra as proteínas recombinantes Lig

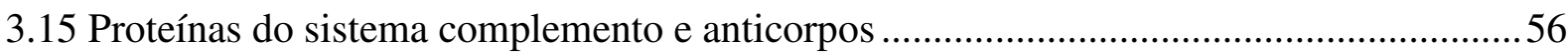

3.16 Análise da interação das proteínas recombinantes de Leptospira com FH e C4BP.........57

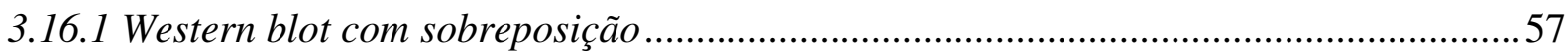

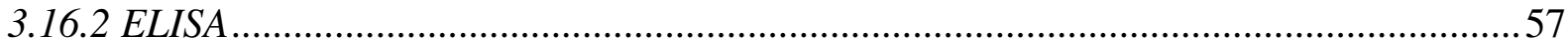

3.17 Avaliação da atividade de co-fator de FH e C4BP ..........................................................58

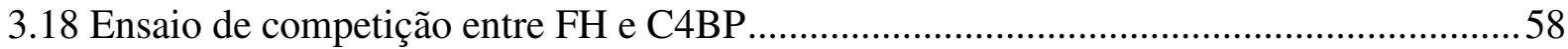

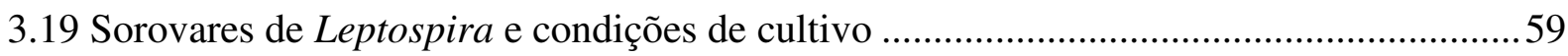

3.20 Avaliação do efeito protetor do FH na sobrevivência da L. interrogans ..........................59

3.21 Avaliação da interação da espécie patogênica L. interrogans sorovar Kennewicki, estirpe Pomona Fromm com FH, FHL-1 e FHR-1 $\alpha / \beta$.

3.22 Avaliação da interação das proteínas Lig com FHL-1, FHR-1, e os domínios SCRs 8-14 e SCRs 15-20 recombinantes por ELISA

3.23 Avaliação da inibição da ligação de FH com a proteína LigBC utilizando anticorpos monoclonais contra diferentes SCRs

3.24 Avaliação por Western blot da interação de leptospiras transgênicas para LigA e LigB com FH e C4BP

3.25 Avaliação da sobrevivência de leptospiras transgênicas para LigA e LigB na presença de soro humano normal

3.26 Avaliação da atividade de co-fator de FH e C4BP ligados na L. biflexa transgênica para LigA ou LigB 62

3.27 Análise por citometria de fluxo da deposição de C3, C4 e MAC em leptospiras 63

3.28 Análise da interação de plasminogênio com as proteínas recombinantes de Leptospira.64 3.28.1 ELISA 64

3.28.2 Western blot com sobreposição 65

3.29 Avaliação da capacidade do plasminogênio ligado às proteínas recombinantes de Leptospira de gerar plasmina 65

3.30 Avaliação da atividade do plasminogênio ligado às proteínas recombinantes de L. interrogans sobre as proteínas do complemento 65

3.31 Avaliação da participação de proteínas do sistema complemento na ativação de polimorfonucleares por leptospiras previamente opsonizadas .66 
4.1 Seleção de proteínas recombinantes de Leptospira interrogans sorovar Copenhageni .....68

4.2 Clonagem dos fragmentos gênicos no vetor pGEM-T Easy

4.3 Subclonagem dos fragmentos gênicos no vetor de expressão pAE...................................69

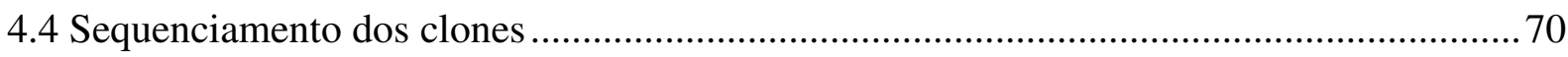

4.5 Expressão e purificação das proteínas recombinantes LigAC, LigBC e LigBN................70

4.6 Avaliação da produção de soros hiperimunes obtidos em camundongos ..........................73

4.7 Análise da interação de Leptospira interrogans com FH, FHL-1 e FHR-1 e da atividade de co-fator

4.8 Análise da interação de proteínas de membrana de L. interrogans com FH e C4BP ........76

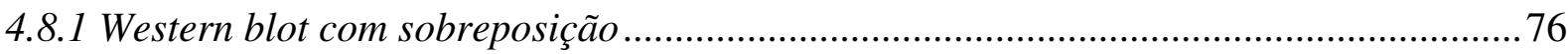

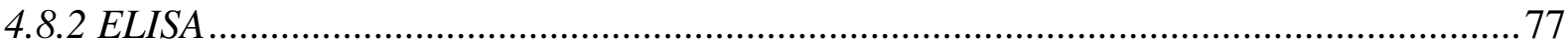

4.11 Avaliação do efeito protetor de FH na sobrevivência de L. interrogans Pomona............. 84

4.12 Interação das proteínas Lig com outras proteínas da família do FH ............................... 85

4.13 Sobrevivência de leptospiras transgênicas L. biflexa sorovar Patoc expressando ligA e $\operatorname{lig} B$ na presença de soro humano normal

4.14 Avaliação da interação de FH e C4BP com as leptospiras transgênicas L. biflexa sorovar Patoc expressando ligA e ligB

4.15 Análise da atividade de FH e C4BP como co-fator de FI na clivagem de C3b e C4b respectivamente em leptospiras transgênicas $L$. biflexa sorovar Patoc expressando ligA e ligB

4.16 Avaliação da interação de C3, C4 e MAC com as leptospiras transgênicas L. biflexa sorovar Patoc expressando ligA e ligB

4.17 Interação das proteínas Lig com plasminogênio

4.18 Análise da interação entre plasminogênio e as proteínas Lig na presença diferentes concentrações de $\mathrm{NaCl}$ e ácido aminocapróico (ACA). 98

4.19 Plasminogênio ligado às proteínas Ligs é convertido em plasmina 100

4.20 Plasmina gerada sobre as proteínas Lig cliva fibrinogênio e as proteínas C3b e C5 do sistema complemento

4.21 Análise da competição entre plasminogênio e FH ou C4BP por sítios de ligação nas proteínas Ligs 106

4.22 Interação de leptospiras com polimorfonucleares 


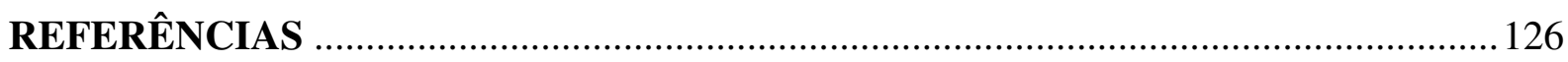

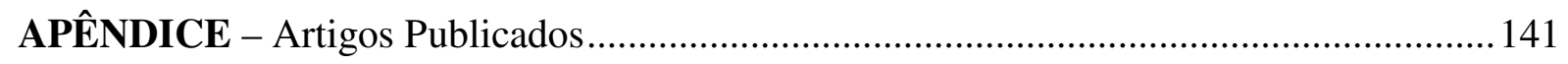




\section{INTRODUÇÃO}

\subsection{A leptospirose}

A leptospirose é uma zoonose emergente, de distribuição mundial, causada pela infecção por espécies patogênicas de Leptospira. O número de casos de leptospirose que ocorrem anualmente não é conhecido com precisão. De acordo com a Organização Mundial da Saúde, a incidência anual é aproximadamente de 5 casos por cada 100.000 indivíduos, excluindo surtos. A estimativa é baixa, uma vez que muitos casos de leptospirose não são notificados e outros tantos não são diagnosticados, devido à falta de conscientização sobre a doença e dificuldades na realização dos testes de confirmação laboratorial (WHO, 2011). A incidência da doença é significativamente mais elevada em países de clima tropical em virtude da sobrevivência prolongada das bactérias em ambientes quentes e úmidos (Bharti et al., 2003; Faine et al., 1999; Levett, 2001). Além das condições climáticas, fatores relacionados a problemas de saneamento básico, agravados pelas enchentes decorrentes de fortes chuvas, aumentam consideravelmente as possibilidades de exposição da população a animais infectados ou ambientes contaminados pela bactéria. A doença é sazonal, com picos de incidência ocorrendo durante as estações chuvosas nos países de clima quente e no verão ou no outono em países de clima temperado (Levett, 2001). Segundo o Ministério da Saúde no Brasil, a leptospirose é uma doença endêmica, tornando-se epidêmica em períodos chuvosos, principalmente nas capitais e áreas metropolitanas, devido às enchentes associadas à aglomeração populacional de baixa renda, a condições inadequadas de saneamento e à alta infestação de roedores infectados. Alguns profissionais são mais vulneráveis para contrair esta infecção por leptospiras como agricultores, veterinários, tratadores de animais, pescadores, trabalhadores em limpeza e desentupimento de esgotos, catadores de lixo, laboratoristas e militares, entre outros. No entanto, no Brasil a maior parte dos casos ainda ocorre entre pessoas que habitam ou trabalham em locais com infra-estrutura sanitária inadequada e permanentemente expostos à urina contaminada de roedores. No período entre 2000 e 2012, foram confirmados em nosso país 47.518 casos de leptospirose (média anual de 3.655 casos). A letalidade média para o período foi de $10 \%$. Entre os casos confirmados o sexo masculino foi o mais atingido (80\%), na faixa etária de 20 a 34 anos (32\%), e do total de casos 4.832 evoluíram para o óbito (Ministério da Saúde de Brasil, 2014).

A leptospirose é transmitida ao ser humano pela exposição ao solo ou água contaminados com a urina de animais infectados. O Rattus norvegicus é o principal 
reservatório associado a epidemias urbanas, pois excreta leptospiras viáveis pela urina capazes de sobreviver por dias ou até semanas no solo ou na água (Faine et al., 1999). Animais selvagens como morcego e veado, animais domésticos como cães e gatos e de interesse econômico como bovinos, suínos e equinos compõem a lista de hospedeiros desta bactéria (Ko et al., 2009).

O período de incubação da leptospirose é de 2 a 20 dias. O desenvolvimento clínico da doença é bifásico: a fase aguda ou septicêmica caracterizada pela presença de leptospiras no sangue dura aproximadamente uma semana, seguida pela fase convalescente ou imune caraterizada pela produção de anticorpos e excreção de leptospiras pela urina (Figura 1). Nesta fase os sintomas iniciam com febre elevada, calafrios, vômitos, derrame conjuntival, cefaleia intensa e mialgia. Grande parte das complicações típicas da infecção decorre da internalização de leptospiras nos tecidos durante a fase imune (Levett, 2001). O espectro de manifestações clínicas é amplo, variando de formas subclínicas até formas graves ou fatais. Nesses casos, a fase septicêmica evolui para uma doença ictérica grave, com disfunção renal, fenômenos hemorrágicos, alterações hemodinâmicas, cardíacas, pulmonares e de consciência, acarretando taxas de letalidade que variam de 5 a 15\% em diversas casuísticas. Recentemente, têm sido observados quadros respiratórios mais graves em nosso meio, que evoluem para insuficiência respiratória aguda com hemorragia pulmonar maciça (Gouveia et al., 2008; Levett, 2001).

Figura 1 - Natureza bifásica da leptospirose e aspectos relevantes em diferentes estágios da doença.

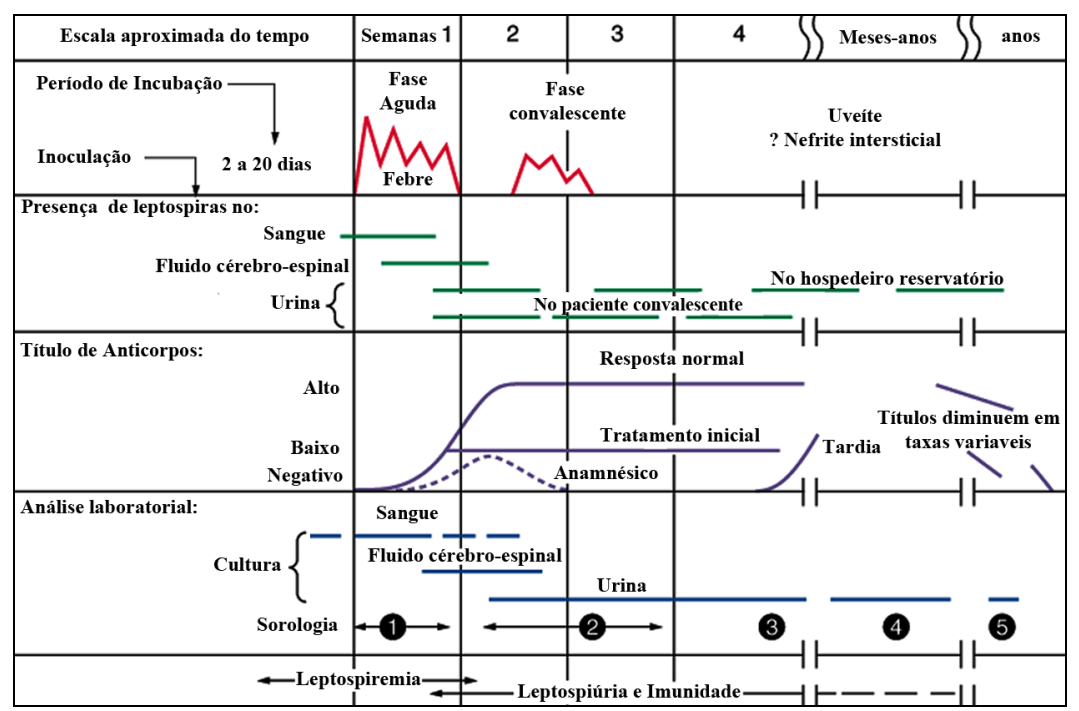

As amostras 1 e 2 de sorologia pertencem a indivíduos de fase aguda e convalescente respectivamente; amostra 3 é característica de uma resposta imune tardia; e os exemplares 4 e 5 são amostras de soro que fornecem informações epidemiológicas, como o suposto sorogrupo infectante (Adaptado de Levett, 2001). 
A maioria dos casos de leptospirose é confirmada por sorologia. Diversas técnicas como Enzyme-Linked Immunosorbent Assay (ELISA), Western blot e inmunofluorescência também são empregadas para o diagnóstico desta doença. No entanto, o método de referência para o diagnóstico da leptospirose é o teste de aglutinação microscópica (MAT), pois além de ser relativamente econômico, possui uma sensibilidade e especificidade de $92 \%$ e $95 \%$ respectivamente (Levett, 2001). Para a realização deste teste, diluições variadas do soro do paciente são incubadas com diferentes suspensões de leptospiras sorovar-específicas. Após breve período de incubação, a reação antígeno-anticorpo é analisada por microscopia de campo escuro para visualização de aglutinação. O título de anticorpos é determinado como a diluição mais alta de soro na qual ocorreu 50\% de aglutinação (Levett, 2001). Embora o MAT seja o método mais empregado para o diagnóstico, este método não permite a detecção da doença em sua fase inicial, pois anticorpos específicos só poderão ser detectados 5 ou 7 dias após o aparecimento dos sintomas. Além disso, requer pessoal treinado em microscopia e infraestrutura para a manutenção de uma ampla bateria de espécies de leptospiras catalogadas por hospedeiro preferencial e região de prevalência. Determinar os tipos de sorovares que prevalecem em cada região, assim como identificar seus hospedeiros, é indispensável para o diagnóstico e entendimento epidemiológico da doença. No entanto, todos esses fatores acabam restringindo o uso deste tipo de técnica a laboratórios de referência (Palaniappan et al., 2007; Ricaldi et al., 2013).

Técnicas como PCR, baseada na amplificação dos genes $16 \mathrm{~S}$ e $23 \mathrm{~S}$ do RNA ribossomal, têm sido também empregadas para a detecção da leptospirose. Esta técnica oferece vantagens uma vez que prescinde da presença de anticorpos, possibilitando a detecção da doença nos seus primeiros dias (Merien et al., 1992; Woo et al., 1997). Contudo, estas técnicas ainda precisam ser aprimoradas de maneira que permitam uma detecção da doença de uma maneira mais rápida e eficaz.

No tratamento contra a leptospirose o uso de antibiótico é amplamente empregado. Os casos mais severos são tratados com doses altas de penicilina endovenosa; já os casos menos graves são tratados com antibióticos orais como amoxicilina, ampicilina, doxiciclina e eritromicina (Levett, 2001). Atualmente, não há vacina licenciada contra a leptospirose humana. No entanto, vacinas desenvolvidas a partir da preparação de leptospiras mortas por formalina ou calor (bacterinas), já foram testadas com pouco êxito em países como Japão (Kitaoka, Inoue, 1952), Cuba (Martínez et al., 2004), e China (Yan et al., 2003). A limitada eficácia deste tipo de vacinas deriva do curto período de proteção que oferecem. A resposta imune gerada pela bacterina carece de memoria imunológica, não é dependente de linfócitos 
T, precisando-se repetir as doses anualmente para manter a imunidade (Faine et al., 1999). Além disso, a vacina é sorovar-específica e, portanto, a proteção dependerá dos sorovares empregados na sua preparação. Assim, para aumentar a eficácia da vacina em determinada localidade geográfica, deve-se agrupar os sorovares mais relevantes na região onde pretende ser aplicada. A bacterina de uso veterinário também apresenta os mesmos problemas e, apesar de proteger contra a doença animais como cães, gatos ou gado não evita a contínua excreção de leptospiras pela urina (Koizumi, Watanabe, 2005). Nos últimos anos, com o intuito de encontrar novos candidatos vacinais contra a leptospirose, antígenos conservados que induzam proteção cruzada contra vários sorovares têm sido investigados como principais alvos de pesquisa na área (Bharti, 2003; Koizumi, Watanabe, 2005).

\subsubsection{Leptospira}

Leptospiras são bactérias espiroquetas, com estrutura helicoidal, que apresentam aproximadamente $0,1 \mu \mathrm{m}$ de largura e 6 a $20 \mu \mathrm{m}$ de comprimento. Possuem dois flagelos com inserções polares, localizados no espaço periplasmático que conferem movimentos de rotação e translação (Levett, 2001). Suas extremidades são curvas, em forma de ganchos (Figura 2). São bactérias aeróbias obrigatórias, crescem bem em temperaturas entre $28{ }^{\circ} \mathrm{C}$ e $30{ }^{\circ} \mathrm{C}$, capazes de formar biofilmes que facilitam uma eficiente colonização e permanência em nichos ecológicos específicos (Ristow et al., 2008).

Figura 2 - L. interrogans sorovar Icterohaemorrhagiae

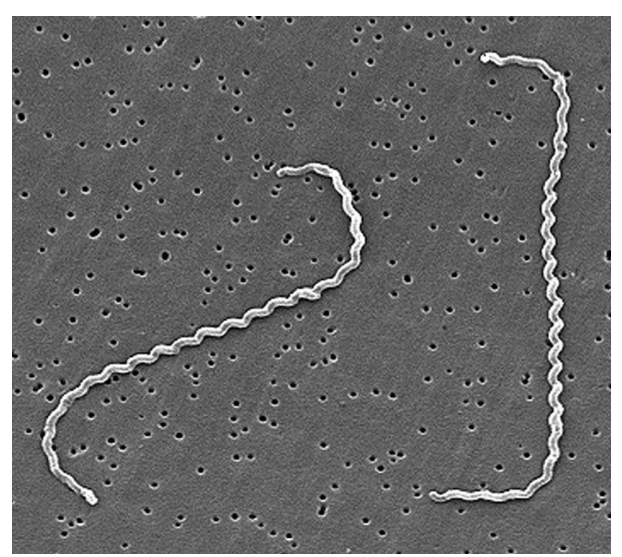

Imagem captada por microscopia eletrônica de $L$. interrogans sorovar Icterohaemorrhagiae cepa RGA sobre membrana de filtro de 0,22 $\mu \mathrm{m}$ (Levett, 2001).

As leptospiras possuem uma membrana dupla contendo lipopolissacarídeo (LPS) que conferem características próprias de bactérias Gram-negativas. No entanto, também 
apresentam uma parede de peptídeoglicanos estreitamente associada à membrana citoplasmática típica de bactérias Gram-positivas (Figura 3) (Evangelista, Coburn et al., 2010). O LPS das leptospiras é estrutural e imunologicamente parecido com o LPS de outras bactérias Gram-negativas, embora seja menos tóxico que o LPS de E. coli. O LPS é um dos principais antígenos de membrana em leptospiras. Diferenças na sua estrutura, composição e localização constituem uma referência importante para classificação sorológica das mesmas. As características incomuns apresentadas pelo lipídio A do LPS de leptospira fazem com que macrófagos humanos sejam ativados via Toll-like receptor (TLR)-2 ao invés de serem tipicamente ativados pelo TLR4. Entretanto, estudos em camundongos mostram que tanto TLR2 quanto TLR4 são importantes para a ativação dos fagócitos (Bharti et al., 2003; Nahori et al., 2005; Werts et al,. 2001).

Figura 3 - Representação esquemática da arquitetura da membrana de Leptospira

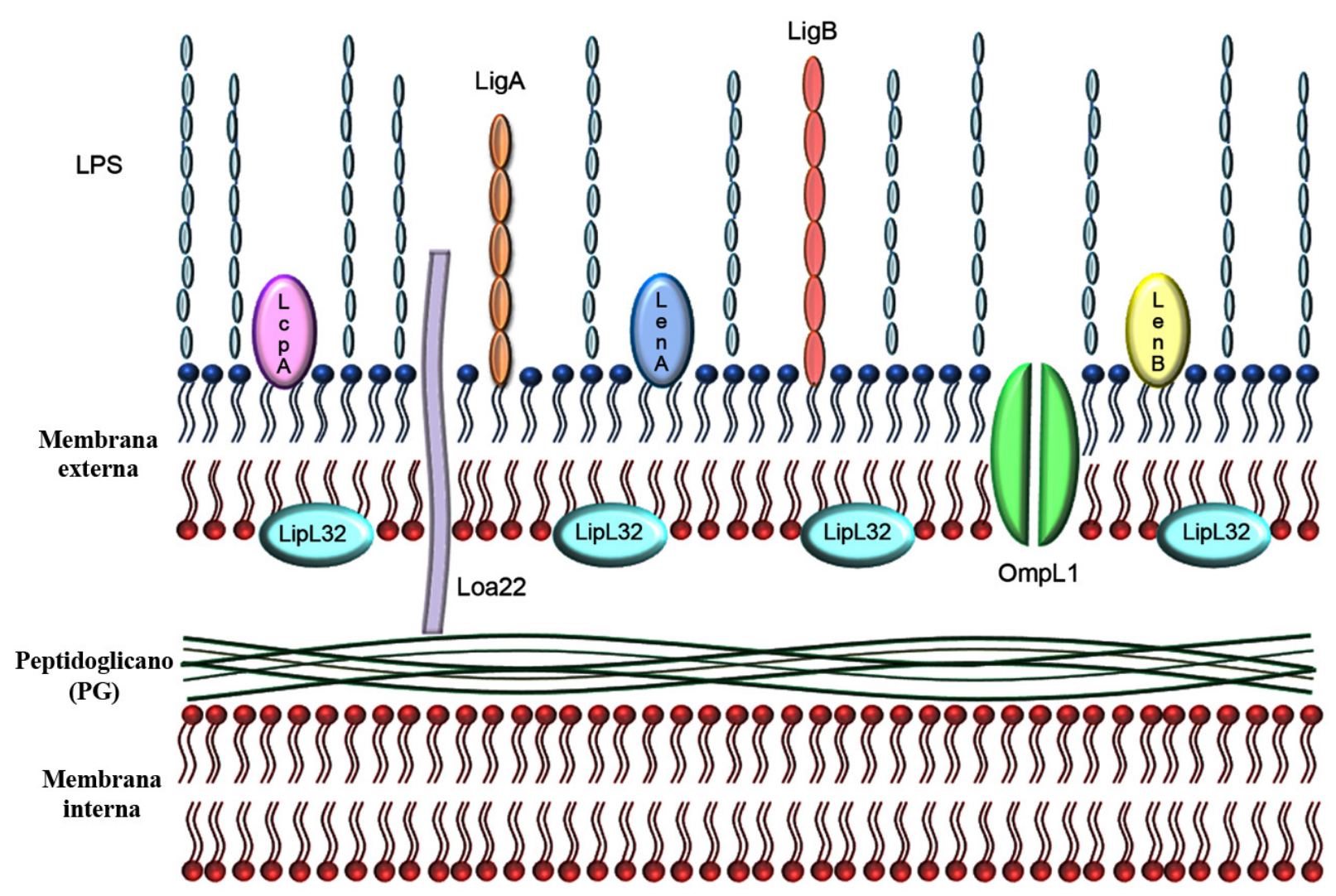

A membrana interna está estreitamente associada a uma parede de peptídeoglicanos a qual se encontra sobreposta por uma outra membrana (Membrana externa). Esta segunda membrana se compõe principalmente de lipopolissacarídeos (LPS), e uma serie de lipoproteínas como LipL32, LigA, LigB, Loa22 e a proteína porina OmpL1 (Fraga et al., 2014). 
Atualmente, dois tipos de classificação de leptospiras coexistem: um baseado em determinantes genéticos e outro em determinantes antigênicos. As duas classificações diferenciam leptospiras em patogênicas e não patogênicas. De acordo com a classificação antigênica, as leptospiras são divididas em duas espécies, L. interrogans que compreende as leptospiras patogênicas com mais de 250 sorovares e L. biflexa que inclui as leptospiras não patogênicas contendo aproximadamente 60 sorovares. Esta classificação especificamente sorológica, fundamenta-se na utilização de antissoros para o estabelecimento de relações antigênicas entre os diferentes isolados (Bharti et al., 2003; Levett, 2001). Por outro lado, a classificação gênica baseada em técnicas de homologia e hibridação de DNA divide as leptospiras em 13 espécies patogênicas: L. alexanderi, L. alstonii, L. borgpetersenii, L. inadai, L. interrogans, L. fainei, L. kirschneri, L. licerasiae, L. noguchi, L. santarosai, L. terpstrae, L. weilii e L. wolffii, e 6 espécies saprofíticas: L. biflexa, L. meyeri, L. yanagawae, L. kmetyi, L. vanthielii e L. wolbachii. Apesar dos determinantes genéticos proporcionarem uma base sólida para uma nova classificação, na prática clínica a tradicional classificação sorológica é mais utilizada (Adler, Moctezuma et al, 2010; Brenner et al., 1999; Levett et al., 2001; Pérolat et al., 1998,). Análises filogenéticas também permitem classificar as leptospiras em três clados, com espécies contendo sorovares patogênicos, não patogênicos e um grupo intermediário (Pérolat et al., 1998).

Nos últimos anos, nove diferentes estirpes de Leptospira tiveram seus genomas sequenciados (Bulach et al., 2006; Chou et al., 2012; Nascimento et al., 2004a; Nascimento et al., 2004b; Picardeau et al., 2008; Ren et al., 2003; Ricaldi et al., 2012). A análise global das sequências sugere a existência de diversos genes possivelmente codificadores de proteínas envolvidas na patogênese da doença. Análises mais detalhadas destes genomas também estão sendo utilizadas na identificação de antígenos conservados na procura de possíveis candidatos vacinais (Gamberini et al., 2005).

Até a presente data, com base em experimentos de mutagênese, apenas quatro fatores de virulência foram descritos em leptospiras: as proteínas Loa22 (Ristow et al., 2007), heme oxigenase (Murray et al., 2009), FliY (proteína chave do motor flagelar) (Liao et al., 2009) e lipopolissacarídeos (Murray et al., 2010). Algumas mutações em outros possíveis fatores de virulência que não resultaram em atenuação da virulência foram realizadas com as proteínas LipL32, LigB, LenB e LenE. Resultados destes estudos sugerem que redundância funcional dos fatores de virulência pode ocultar ou camuflar os fenótipos de atenuação (Adler et al., 2011). 


\subsubsection{Patogenicidade}

Leptospiras patogênicas rompem as barreiras teciduais penetrando por meio de abrasões na pele e mucosas, podendo atingir a corrente circulatória, onde se multiplicam e disseminam. Por outro lado, leptospiras não patogênicas são rapidamente eliminadas, principalmente por fagocitose e ativação do sistema complemento (Meri et al., 2005). Durante o processo de infecção, colonizam órgãos como baço, fígado, pulmão e principalmente rim, onde persistem aderidas ao epitélio dos túbulos renais. Este local é rico em nutrientes provenientes do filtrado glomerular, e funciona como nicho ideal para a multiplicação e disseminação de leptospiras em novos hospedeiros por meio da urina contaminada (Ko et al., 2009).

As leptospiras patogênicas fazem uso de diferentes estratégias para invasão, disseminação e permanência no hospedeiro. Já foram descritos alguns trabalhos mostrando a capacidade das leptospiras de aderirem às células endoteliais, fibroblastos, monócitos, macrófagos (Merien et al., 1997, Thomas, Highble, 1990), componentes de matriz extracelular como colágeno tipo I e IV, laminina e fibronectina (Atzingen et al., 2008; Barbosa et al., 2006) e a proteínas do sistema complemento como fator $\mathrm{H}$ (FH) e C4b-binding protein (C4BP) (Barbosa et al., 2009; Meri et al., 2005; Verma et al., 2006).

As leptospiras também possuem hemolisinas, proteínas com capacidade de romper membranas de eritrócitos e provocar lise celular, liberando grandes quantidades de ferro, indispensáveis para a sobrevivência desta bactéria no hospedeiro (Wandersman, Stojiljkovic, 2000). Fatores de virulência como as hemolisinas também podem atuar como elementos importantes na aquisição de fontes de carbono e energia a partir de lipídeos presentes na membrana (Carvalho et al., 2009). Em leptospiras a hemólise é também caracterizada pela atividade de fosfolipases (Trowbridge et al., 1981), esfingomielinases (Segers et al., 1990) e de outras proteínas auxiliares (Lee et al., 2000). Curiosamente, a atividade hemolítica de algumas hemolisinas como a proteína TlyC, não foi confirmada experimentalmente. No entanto, esta proteína interage com componentes da matriz extracelular (Carvalho et al., 2009).

Conforme mencionamos anteriormente, algumas lipoproteínas presentes na membrana de leptospiras patogênicas já foram descritas como fatores de virulência como a Loa22, sendo a única a cumprir os postulados moleculares de Koch para a determinação de um fator de virulência; mutagênese de Loa22 resulta na perda completa da virulência em modelo de hamster (Ristow et al., 2007). Esta proteína também apresenta a capacidade de interagir com 
peptídeoglicanos (Koizumi, Watanabe, 2003). A LipL32 é uma das lipoproteínas mais abundantes e altamente conservada entre as espécies patogênicas e foi descrita pela sua capacidade de interagir com laminina, colágeno II, IV e V e fibronectina plasmática (Hauk et al., 2008). Contudo, experimentos de mutagênese mostraram que esta proteína não atenua a virulência da bactéria (Murray et al., 2009). LfhA, outra lipoproteína de membrana importante, interage com FH e Factor $H$ related protein-1 (FHR-1) (Verma et al., 2006), plasminogênio (Verma et al., 2010) e laminina (Barbosa et al., 2006).

As Leptospiral immunoglobulin-like proteins (Ligs) são proteínas de superfície com alto peso molecular que apresentam domínios Bacterial immunoglobulin-like (Big) repetidos em sequência (Palaniappan et al., 2002). Nos genomas de Leptospira foram descritos três membros desta família: $\operatorname{lig} A, \operatorname{lig} B$ e $\operatorname{lig} C$. A sequência $\mathrm{N}$-terminal de 630 aminoácidos da LigA e da LigB é idêntica, mas a porção C-terminal é variável apresentando apenas $34 \%$ de identidade. LigB possui um domínio C-terminal extra, com 771 resíduos de aminoácidos (Palaniappan et al., 2004). O ligC é um pseudogene em L. interrogans sorovar Copenhageni e L. kirshneri sorovar Grippotyphosa (Fraga et al., 2011; Matsunaga et al., 2003). Os genes lig estão presentes apenas nas espécies patogênicas e sua expressão está intimamente associada ao processo de infecção do hospedeiro. As proteínas são expressas em cepas virulentas, mas não em culturas atenuadas de leptospiras. Além disso, as proteínas Ligs são capazes de induzir a produção de anticorpos específicos em pacientes e animais infectados (Koizumi, Watanabe, 2004; Matsunaga et al., 2003; Palaniappan et al., 2002). Estudos recentes têm apontado estas proteínas como ótimas candidatas vacinais para leptospirose, conferindo entre $70 \%$ e $100 \%$ de proteção em modelos animais (Faisal et al., 2008; Faisal et al., 2009; Koizumi, Watanabe, 2004; Palaniappan et al., 2006; Silva et al., 2007; Yan et al., 2009), apesar dos animais continuarem portadores. No entanto, Croda et al., (2008) observaram que a cepa de L. interrogans mutante para o gene ligB não era menos virulenta no modelo animal de leptospirose. Talvez seja necessário um duplo mutante para ligA e $\operatorname{lig} B$ para se conseguir uma atenuação significativa da virulência desta bactéria.

As proteínas Ligs são capazes de interagir com diversos componentes da matriz extracelular, incluindo fibronectina, laminina, colágeno, elastina, fibrinogênio e tropoelastina (Choy et al., 2007; Lin, Chang, 2007; Lin, Chang, 2008; Lin et al., 2009; Lin et al., 2010). Devido a essas propriedades, as Ligs foram classificadas como microbial surface components recognizing adhesive matrix molecules (MSCRAMMs), uma categoria importante de proteínas de bactérias envolvidas na colonização dos tecidos do hospedeiro (Choy et al., 2007). 
Outro aspecto importante relacionado com a patogênese da leptospira é o papel que desempenham os TLRs no reconhecimento desta bactéria. Estudos demonstram que o sistema imune também reconhece ou detecta as leptospiras por meio dos TLRs e os Nod-like receptors (NLRs). O reconhecimento das leptospiras por células murinas é mediado tanto pelo TLR2 quanto pelo TLR4, enquanto em células humanas unicamente TLR2 é ativado pelo LPS das leptospiras (Nahori et al., 2005; Werts et al,. 2001). O TLR5 também é capaz de reconhecer flagelina de leptospiras (Goris et al., 2011). Leptospiras patogênicas são resistentes à morte por fagocitose em neutrófilos, mas na presença de anticorpos específicos são rapidamente eliminadas (Wang et al., 1984).

\subsection{Sistema Complemento}

O sistema complemento é um conjunto de aproximadamente 40 proteínas presentes no plasma ou ligadas a membranas celulares. A ativação do complemento pode ser iniciada por três vias diferentes: via alternativa, via das lectinas e via clássica. Este sistema desempenha um papel essencial na eliminação de micro-organismos, inflamação e remoção de imunocomplexos e células apoptóticas (Köhl, 2006).

A ativação da via clássica inicia-se preferencialmente quando $\mathrm{C} 1 \mathrm{q}$ ao se ligar a complexos antígeno-anticorpo, ativa $\mathrm{C} 1 \mathrm{r}$ e este ativará $\mathrm{C} 1$ s. $\mathrm{C} 1 \mathrm{~s}$ ativado, por sua vez, cliva $\mathrm{C} 4$ e $\mathrm{C} 2$, gerando os fragmentos $\mathrm{C} 4 \mathrm{~b}$ e $\mathrm{C} 2 \mathrm{a}$, respectivamente. A via das lectinas é ativada quando lectinas como Mannose Binding Lectin (MBL) ligam-se a açúcares como manose e Nacetilglicosamina, normalmente presentes na parede celular de vários micro-organismos, ativando serino proteases associadas à MBL (MASPs) que também são capazes de clivar os componentes $\mathrm{C} 4$ e C2. Produtos da clivagem de $\mathrm{C} 4$ e $\mathrm{C} 2$ formam a $\mathrm{C} 3$ convertase (C4bC2a) das vias clássica e das lectinas, a qual cliva C3 em C3a e C3b. Fragmentos C3b podem se associar a $\mathrm{C} 4 \mathrm{bC} 2 \mathrm{a}$, formando a $\mathrm{C} 5$ convertase das vias clássica e das lectinas $\mathrm{C} 4 \mathrm{bC} 2 \mathrm{aC} 3 \mathrm{~b}$ (Walport, 2001).

$\mathrm{Na}$ ausência de anticorpos específicos a via alternativa pode ser ativada na superfície de vários patógenos, iniciando-se a partir da hidrólise espontânea da ligação tiol-éster localizada na cadeia alfa do componente $\mathrm{C} 3$, gerando $\mathrm{C} 3\left(\mathrm{H}_{2} \mathrm{O}\right)$. Esta molécula permite a ligação de uma proteína plasmática conhecida por Fator B (FB), formando assim o complexo $\mathrm{C} 3\left(\mathrm{H}_{2} \mathrm{O}\right) \mathrm{B}$. Nesta condição, o FB então é clivado pela enzima denominada Fator D (FD) gerando $\mathrm{C} 3\left(\mathrm{H}_{2} \mathrm{O}\right) \mathrm{Bb}$, que na presença de íons $\mathrm{Mg}^{++}$exibe atividade de serino-protease, clivando o $\mathrm{C} 3$ em C3a e C3b. Assim como o C3( $\left.\mathrm{H}_{2} \mathrm{O}\right)$, C3b também apresenta sítio de ligação 
para $\mathrm{FB}$, formando o complexo $\mathrm{C} 3 \mathrm{bBb}$, após clivagem do $\mathrm{FB}$ em $\mathrm{Bb}$ e Ba pelo $\mathrm{FD}$. O $\mathrm{C} 3 \mathrm{bBb}$ atua então como C3 convertase, clivando mais moléculas de $\mathrm{C} 3$, formando $\mathrm{C} 3 \mathrm{bBbC} 3 \mathrm{~b}$ ( $\mathrm{C} 5$ convertase) que cliva C5 em C5a e C5b. A properdina estabiliza a C3 convertase, sendo, portanto, um regulador positivo da via alternativa. Todas as três vias convergem em uma via terminal comum na qual é formado o complexo de ataque à membrana (MAC), que forma poros ou canais transmembrana que afetam o equilíbrio osmótico da célula provocando sua lise (Figura 4) (Morgan, Harris, 1999; Walport, 2001).

$\mathrm{O}$ sistema complemento participa ativamente dos mecanismos da imunidade inata e adquirida. Entre suas várias funções biológicas, as mais estudadas são: a) produção de opsoninas desempenhadas principalmente pelos fragmentos iC $3 b, C 3 b, C 3 d$; b) produção de fatores quimiotáticos, especialmente C5a, capazes de atrair células inflamatórias para o sítio de ativação; c) produção de anafilatoxinas capazes de desgranular mastócitos e basófilos, liberando assim vários mediadores inflamatórios; d) lise celular provocada pela formação de poro na superfície ativadora (MAC); e) efeito adjuvante, causando aumento na produção de anticorpos pelos linfócitos e f) remoção de imunocomplexos e células apoptóticas (Walport, 2001).

Figura 4 - Ativação do Sistema de Complemento.

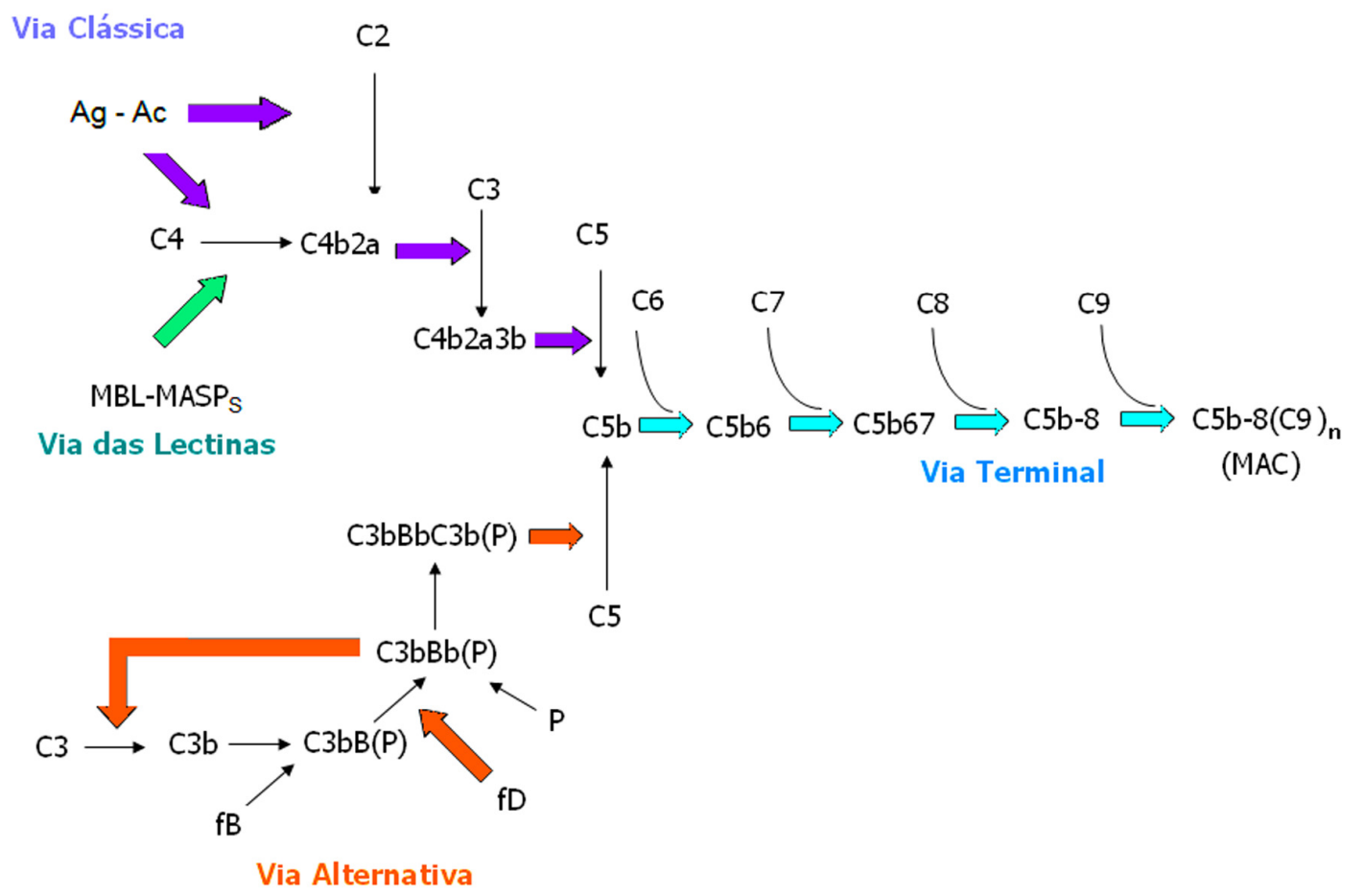

As três vias culminam na via terminal comum com a formação do complexo de ataque à membrana (MAC), causando a lise da célula. MBL: mannose binding lectin; MASPs: serino proteases associadas à MBL, P: properdina; fB: Fator B; fD: Fator D. (Morgan, Harris, 1999). 


\subsubsection{Regulação do sistema complemento}

Para regular a ativação deste sistema sobre as células do hospedeiro e evitar o consumo exagerado de proteínas do complemento, várias proteínas reguladoras são encontradas no plasma ou inseridas na membrana celular do próprio indivíduo. Entre os principais reguladores plasmáticos do sistema complemento, encontram-se o FH responsável pela regulação da via alternativa e C4BP responsável pela regulação da ativação do complemento tanto na presença de anticorpos (via clássica), quanto pela via das lectinas (imunidade inata) (Barnum, 1991, Walport 2001). Esses reguladores aceleram o decaimento das C3 convertases (C3bBb e C4b2a respectivamente) (Gigli et al., 1985; Misasi et al., 1989; Weiler et al., 1976) e ambos agem como co-fatores de Fator I (FI), enzima responsável pela clivagem irreversível de $\mathrm{C} 3 \mathrm{~b}$ e $\mathrm{C} 4 \mathrm{~b}$, respectivamente, impedindo assim a continuidade da ativação em cascata do sistema complemento pelas três vias de ativação. Dessa maneira, a aquisição desses dois reguladores plasmáticos por um patógeno pode impedir a sua própria destruição mediada pela ativação da via alternativa $(\mathrm{FH})$ e das vias clássica e das lectinas (C4BP) do sistema complemento do hospedeiro. (Figuras 5 e 6).

Figura 5 - Inibição da ativação da via alternativa por FH.

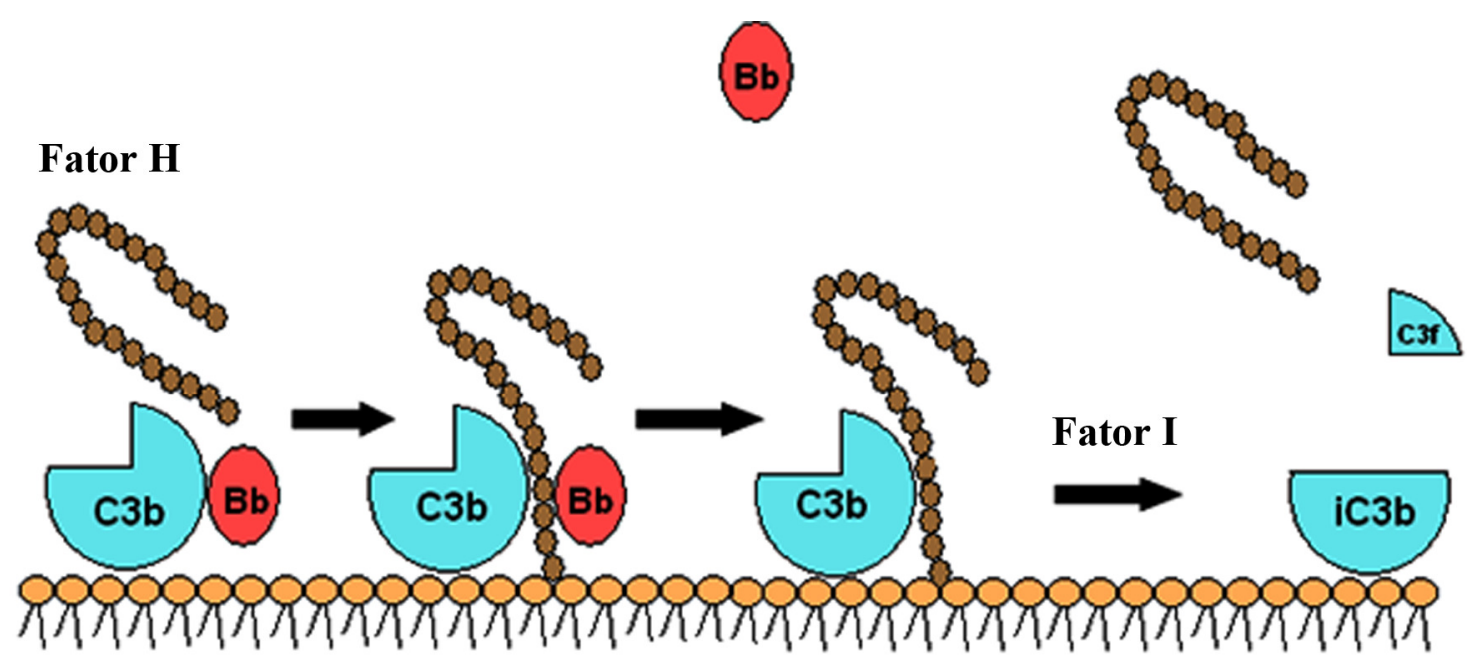

Decaimento da atividade de $\mathrm{C} 3$ convertase

Atividade de co-fator do FI

Ao se ligar em C3b, o Fator $\mathrm{H}$ desloca a interação entre $\mathrm{C} 3 \mathrm{~b}$ e $\mathrm{Bb}$, desfazendo o complexo $\mathrm{C} 3 \mathrm{bBb}$, a C3 convertase da via alternativa. Além disso, atua como co-fator de Fator I na clivagem de C3b em iC $3 b$. Em ambas as funções, Fator H impede a formação e manutenção da C3 convertase da via alternativa, interrompendo assim a sua contínua ativação (Morgan, Harris, 1999). 
Figura 6 - Inibição da via clássica ou das lectinas por C4BP.
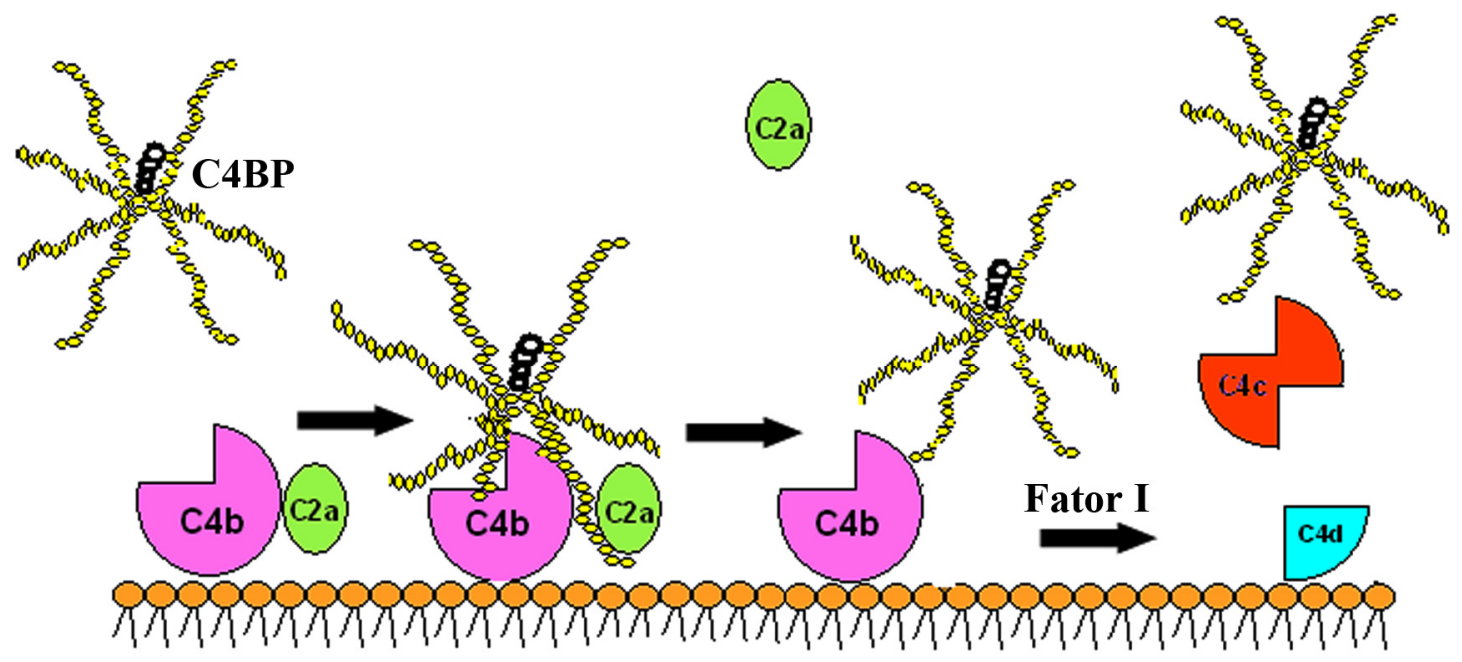

Decaimento da atividade de $\mathbf{C} 3$ convertase

Atividade de co-fator do FI

Ao se ligar em C4b, C4BP desloca a interação entre C4b e C2a, e, além disso, atua como co-fator de Fator I na clivagem de $\mathrm{C} 4 \mathrm{~b}$ em $\mathrm{C} 4 \mathrm{c}$ e $\mathrm{C} 4 \mathrm{~d}$. Em ambas as atividades, C4BP impede a formação/manutenção da C3 convertase das vias clássica e das lectinas, interrompendo assim a contínua ativação das mesmas. (Morgan, Harris, 1999).

\subsubsection{Fator $H$}

O FH, composto por 20 domínios Short Consensus Repeats (SCR), é uma proteína de $150 \mathrm{kDa}$ e o mais conhecido e abundante membro entre as proteínas da chamada família do FH. Sua concentração sérica é de 242-759 $\mu \mathrm{g} / \mathrm{ml}$ (De Paula et al., 2003). A porção N-terminal (SCRs 1-4) é encarregada de realizar a atividade reguladora de co-fator de FI. A porção Cterminal (SCRs 18-20) medeia a ligação de FH à membrana celular e a distinção de superfícies-alvo. Esta região também possui sítios de ligação à heparina, C3b, C3d, ácido siálico e fatores de virulência microbianos (Manuelian et al., 2003, Oppermann et al., 2006, Sherka, Zipfel, 2008) (Figura 7). Os SCRs 7 e 9 ligam-se à heparina e os SCRs 11-15 possuem sítios de ligação a C3b/C3c.

Os outros membros da família do FH incluem FH-like-protein 1 (FHL-1), gerado por splicing alternativo do mesmo gene $H f$ e as proteínas relacionadas $F H$-related (FHR), FHR-1, FHR-2, FHR-3, FHR-4, FHR-5 codificadas por genes distintos, mas localizados proximamente em uma região gênica do cromossomo 1 humano (Córdoba et al., 1999). Os membros da família do FH são glicoproteínas, compostas exclusivamente de domínios SCRs, com alto grau de identidade ou similaridade entre si (Sherka, Zipfel, 2008) (Figura 7).

O FHL-1 é composto por 431 aminoácidos. Os primeiros 427 aminoácidos formam sete SCRs que são idênticos aos sete primeiros SCRs da região N-terminal do FH. Os quatro 
aminoácidos restantes Ser-Phe-Thr-Leu (SFTL) compõem a região C-terminal de FHL-1 e são codificados pelo éxon 10 (Córdoba et al., 2004). O FHL-1 é constitutivamente produzido pelo fígado e é encontrado em concentrações plasmáticas de 10-50 $\mu \mathrm{g} / \mathrm{ml}$. Assim como o FH, FHL-1 também possui atividade reguladora, conferida pelos SCRs 1-4 (Estaller et al., 1991; Kuhn et al., 1995; Misasi et al., 1989; Zipfel et al., 1999).

As proteínas FHR-1, FHR-2, FHR-3, FHR-4 e FHR-5 são também sintetizadas no fígado e suas concentrações no plasma são muito menores que as de FH. As propriedades funcionais destas proteínas não estão ainda totalmente definidas. Todas são compostas por SCRs com diferentes graus de homologia com FH (Figura 7). Este grupo de proteínas não possui os SCRs 1 ao 5 e, portanto, carecem da potente atividade regulatória sobre a C3 convertase exercida pelo FH (Timmann et al., 1991; Hellwage et al., 1999). Porém, uma leve atividade moduladora foi reportada pelas proteínas FHR3 e FHR4 (Hellwage et al., 1999, Sherka, Zipfel, 2008). O mecanismo exato de regulação destas proteínas é ainda desconhecido, mas, provavelmente, está relacionado com propriedade de se ligarem ao fragmento C3b. De maneira similar, FHR-5 apresenta atividade de cofator de FI, desacelerando o decaimento da C3 convertase (McRae et al., 2005; Sherka, Zipfel, 2008). FHR-1 também é capaz de interferir na deposição de C5b, bloqueando a atividade da C5 convertase e, portanto, a deposição do MAC (Heinen et al., 2009). 
Figura 7 - Representação dos domínios SCRs que compõem as proteínas da família do FH.

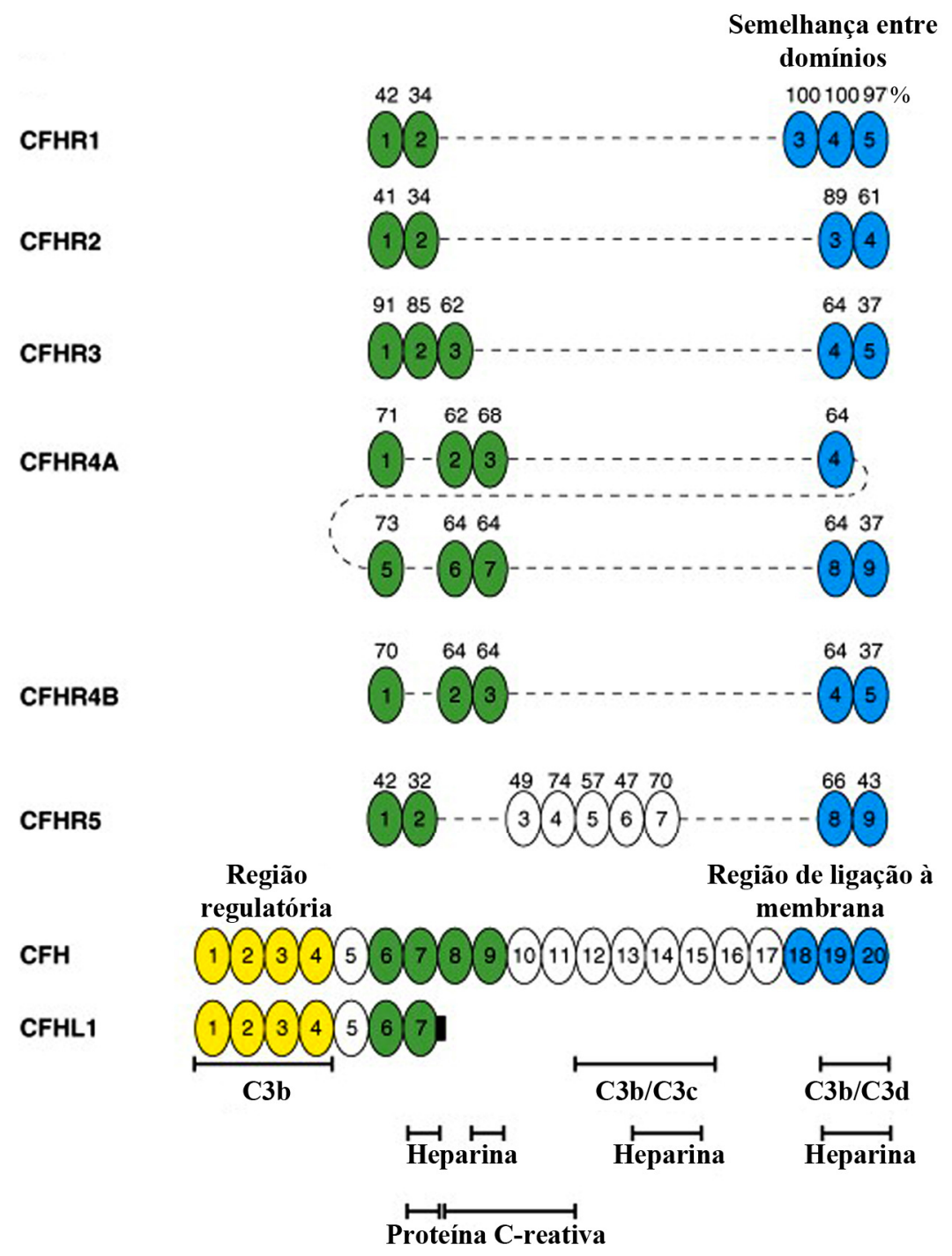

Os números acima dos domínios SCRs correspondem à porcentagem de identidade ou similaridade com domínios presentes no FH. Estão indicadas as regiões associadas às funções destas proteínas e sítios para ligação de heparina, C3b e proteína C-reativa (Józsi, Zipfel, 2008).

\subsubsection{C4b Binding Protein}

C4BP é uma glicoproteína plasmática de $570 \mathrm{kDa}$, composta estruturalmente por sete cadeias $\alpha$ idênticas de $70 \mathrm{kDa}$ e uma única cadeia $\beta$ de $45 \mathrm{kDa}$ unidas a um núcleo central (Persson, Lindahl, 2005). Esta proteína inibe a ativação do sistema complemento, pois atua como co-fator do FI na degradação de C4b e também previne e acelera o decaimento da $\mathrm{C} 3$ convertase (C4b2a) da via clássica e via das lectinas. As duas cadeias $\alpha$ e $\beta$ de C4BP são compostas por domínios SCRs contendo aproximadamente 60 aminoácidos cada um (Figura 8). 
C4BP está presente no plasma em três isoformas. A principal isoforma é $\alpha 7 / \beta 1$. As outras duas isoformas presentes no plasma são $\alpha 7 / \beta 0$ e $\alpha 6 / \beta 1$. As cadeias $\alpha$ e $\beta$ são unidas por pontes dissulfeto na região C-terminal (Blom et al., 2004).

Figura 8 - Representação esquemática de C4BP indicando seus sítios de interação com diversos ligantes.

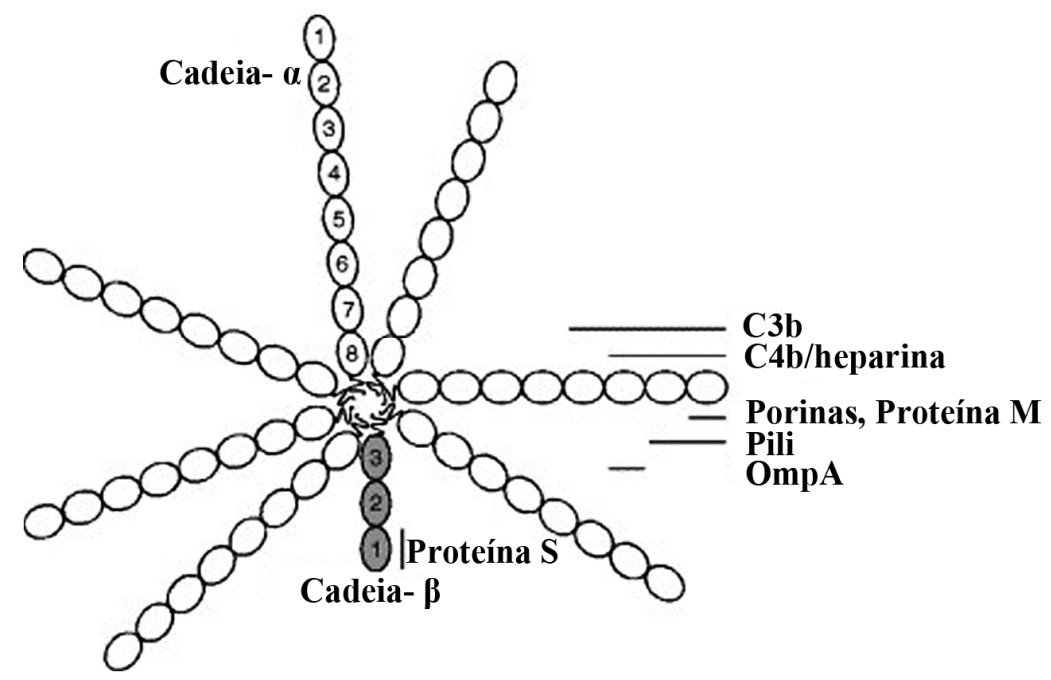

C4BP é um polímero de 7 cadeias $\alpha$ idênticas que possuem diferentes sítios de ligação na região N-terminal. A única cadeia $\beta$ presente em $70 \%$ das moléculas forma complexos de alta afinidade com a proteína $\mathrm{S}$, com função anticoagulante. (Blom et al., 2004).

\subsection{Sistema fibrinolítico}

O processo da coagulação é regulado pela fibrinólise, envolvendo uma cascata enzimática distinta que permite a remoção de depósitos de fibrina. $\mathrm{O}$ componente chave deste sistema é o plasminogênio (PLG) que pode ser convertido em plasmina (PLA) na presença de ativadores como o ativador tecidual de plasminogênio (tPA) e o ativador de plasminogênio tipo uroquinase (uPA). O tPA é o principal ativador envolvido na fribrinólise, uma vez que a geração de PLA é realizada sobre a superfície da fibrina, enquanto a uPA é responsável pela geração da PLA solúvel (Bergmann, Hammerschmid, 2007; Oikonomopoulou et al., 2012).

O sistema fibrinolítico é formado por um amplo espectro de enzimas proteolíticas que regulam a produção de plasmina a partir do plasminogênio (pró-enzima inativa) e tem como função principal a degradação dos coágulos de fibrina pela ação enzimática da plasmina (Figura 9). Além da sua ação fibrinolítica, a plasmina e os ativadores do plasminogênio apresentam várias outras funções fisiológicas como proliferação tecidual, adesão celular, e degradação proteolítica de laminina, vitronectina, metaloproteases de matriz como pro- 
colagenases e componentes de matriz extracelular (ECM), tanto no sistema sanguíneo como nos tecidos sólidos. Também intervém em alguns processos biológicos como regeneração tecidual, cicatrização, menstruação, implantação embrionária, hemostasia assim como em algumas patologias como tromboses, arteriosclerose e invasão tumoral (Collen, 1999; Zorio et al., 2008).

Figura 9 - Sistema fibrinolítico e sua utilização por bactérias.

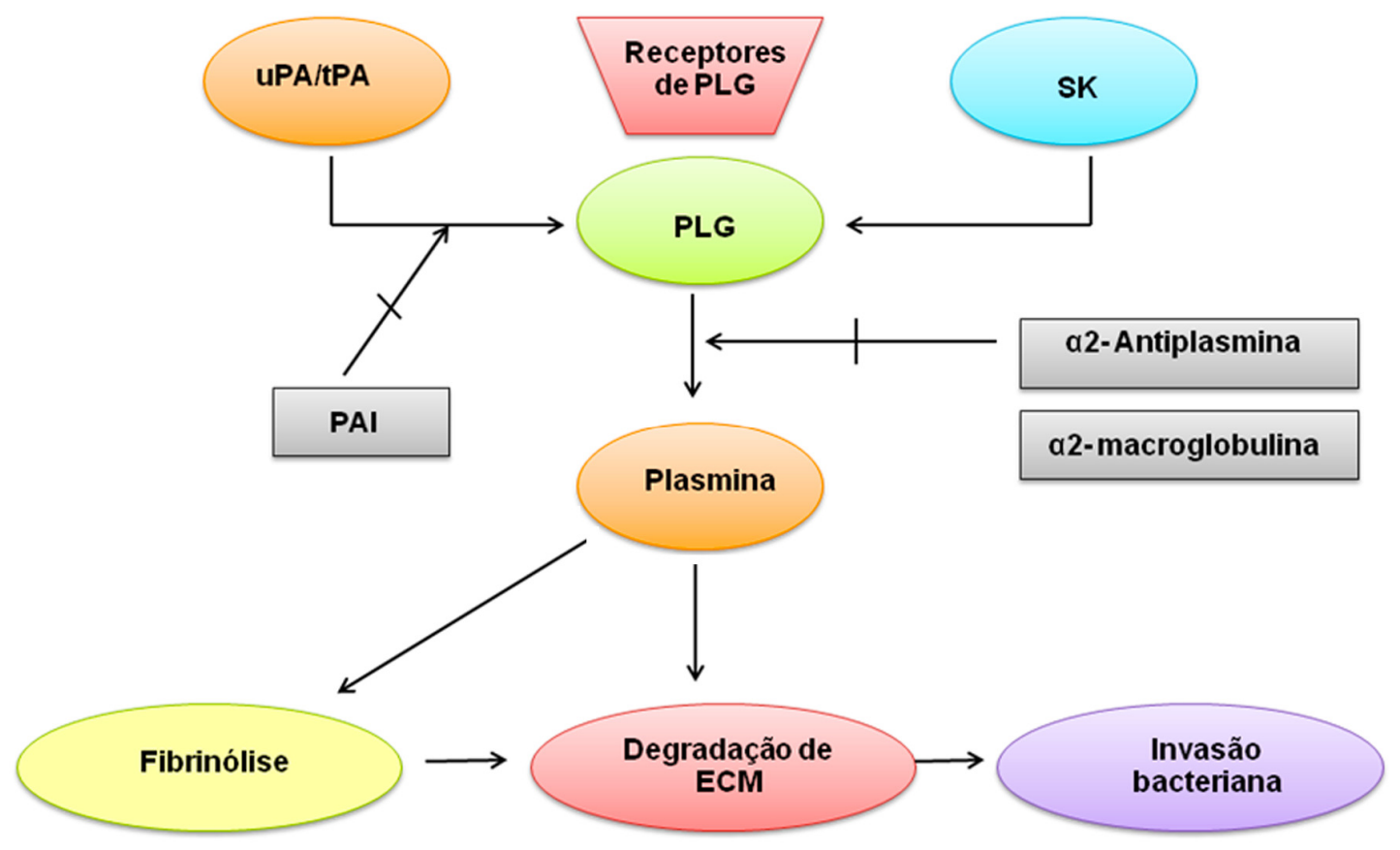

O plasminogênio (PLG) é imobilizado na superfície de algumas bactérias graças à presença de receptores, que permitem a sua conversão em plasmina pela ação dos ativadores uPA e tPA presentes no hospedeiro ou por ativadores bacterianos (SK) como a estreptoquinase (STK) ou estafiloquinase (SAK). Entretanto, estes ativadores podem ser inibidos pelos inibidores dos ativadores de plasminogênio (PAIs), enquanto a plasmina ativa é controlada pelo principal inibidor $\alpha 2$ - antiplasmina. A plasmina degrada coágulos de fibrina (fibrinólise) e vários componentes de matriz extracelular (ECM), o que permite a migração de bactérias através das barreiras teciduais (Bhattacharya et al., 2012).

\subsubsection{Plasminogênio e plasmina}

O plasminogênio é uma proteína plasmática de $90 \mathrm{kDa}$, sintetizada principalmente pelo fígado, circula na concentração de 180-200 $\mu \mathrm{g} / \mathrm{ml}$ (Lahteenmaki et al., 2001). É composto por 791 aminoácidos organizados em 7 domínios estruturais. A porção N-terminal da molécula compreende um peptídeo de ativação (AP) e cinco domínios kringle (K1-K5) com sequências homólogas seguidas por um domínio catalítico C- terminal (Figura 8). O 
plasminogênio é convertido em plasmina pela ação proteolítica do ativador tecidual (tPA) e o ativador tipo uroquinase (uPA) entre os aminoácidos $\mathrm{Arg}^{561}-\mathrm{Val}^{562}$, dividindo o plasminogênio em duas cadeias unidas por pontes dissulfeto. A cadeia pesada de $65 \mathrm{kDa}$ formada por 561 aminoácidos compreende a porção N-terminal do plasminogênio, e a cadeia leve de 230 aminoácidos compreende a porção C-terminal e um domínio catalítico semelhante a serino protease (Bhattacharya et al., 2012; Parry et al., 2000) (Figura 8).

A função principal da plasmina é degradar a fibrina; no entanto, também atua sobre outros componentes de matriz extracelular como o colágeno IV e V, laminina, fibronectina, vitronectina entre outros. A plasmina livre no sangue é inativada rapidamente pela $\alpha 2-$ antiplasmina, sendo sua meia vida de 0,1 segundo. Contudo, a plasmina gerada na superfície da fibrina está parcialmente protegida desta inativação. Isto acontece porque os sítios de ligação em lisinas são importantes para a interação entre a plasmina e a fibrina ou a $\alpha 2$ - antiplasmina (Bhattacharya et al., 2012). Se os sítios que ligam lisinas nos domínios kringle 1-3 estiverem ocupados, a ação da $\alpha 2$ - anti-plasmina é 50 vezes menor, uma vez que a plasmina fica protegida de uma degradação rápida (Parry et al., 2000).

$\mathrm{Na}$ infecção bacteriana são formados depósitos de fibrina, e estes coágulos podem interferir na mobilidade da bactéria impedindo sua disseminação pelos diferentes tecidos. Bactérias com a capacidade de gerar plasmina na sua superfície podem fazer fibrinólise, prevenindo a formação de coágulos de fibrina e permitindo a liberação das bactérias (Coleman, Benach, 1999).

Figura 10 - Representação da estrutura do plasminogênio humano.

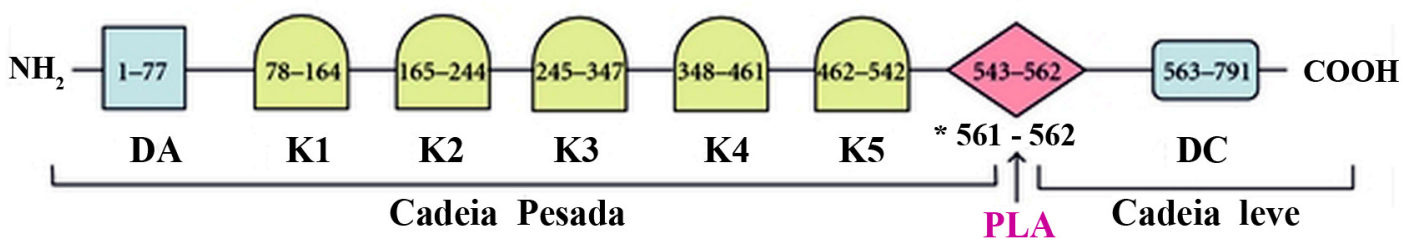

Domínio de ativação (DA) formado pelos aminoácidos 1-77, seguido por cinco domínios kringle (K1-K5) contendo sítios de ligação à lisina e um domínio catalítico (DC). O sítio de clivagem para geração de plasmina (PLA) entre os aminoácidos 561-562 promove a formação da cadeia leve e pesada unidas por pontes dissulfeto (Bhattacharya et al., 2012). 


\subsubsection{Ativadores do Plasminogênio (APS)}

O plasminogênio está presente em grandes quantidades no sangue e nos tecidos. Devido à importância do plasminogênio e da plasmina nos processos biológicos, é de extrema importância que este grande reservatório proteolítico seja altamente regulado. Isto é obtido através de ativadores, inibidores e receptores, a fim de restringir a geração de plasmina, bem como pela imobilização de plasminogênio nos seus receptores, ou moléculas alvo (Collen, 1999). Os mamíferos possuem dois ativadores de plasminogênio: o ativador tecidual de plasminogênio (tPA) e o ativador de plasminogênio tipo uroquinase (uPA). Eles reconhecem e clivam a ligação peptídica R561-V562 no plasminogênio, gerando plasmina (Bhattacharya et al., 2012; Lahteenmaki et al., 2001). O uPA é um importante ativador de plasminogênio durante a migração e invasão celular em condições fisiológicas e patológicas, enquanto o tPA é o principal ativador do plasminogênio na fibrinólise e manutenção da permeabilidade vascular.

\subsubsection{Ativador Tecidual de Plasminogênio (tPA)}

O tPA é uma serino protease de $70 \mathrm{kDa}$ presente no plasma em concentrações de $5 \mathrm{a}$ $10 \mathrm{ng} / \mathrm{ml}$, abundante no útero e sistema nervoso central. É sintetizado principalmente pelas células endoteliais vasculares como uma única cadeia polipeptídica que contém 530 aminoácidos (Lahteenmaki et al., 2001; Rijken, 1995). Depois de liberado no sangue, sua meia-vida é de 5-10 min, a menos que encontre um sítio de ligação específica na fibrina (Rijken, 1995). Dada a alta afinidade do tPA pela fibrina, a ativação do plasminogênio pelo tPA ocorre preferencialmente sobre esta estrutura ou sobre a superfície das células endoteliais, fato que garante uma eficiente e localizada ativação do plasminogênio.

\subsubsection{Ativador de plasminogênio tipo uroquinase (uPA)}

O uPA é uma serino protease de $54 \mathrm{kDa}$ formada por 411 aminoácidos. É sintetizado e secretado por uma grande variedade de células endoteliais, células musculares lisas, fibroblastos, etc. Sua concentração no plasma é 3,5 ng/ml e na urina é 200 a $300 \mathrm{ng} / \mathrm{ml}$. Possui uma meia-vida de 15 min. Suas principais funções são mediar a degradação de matriz extracelular durante a inflamação, reparação tecidual, além de promover a metástase tumoral. O uPA se liga ao receptor específico uPAR, aumentando assim sua eficiência catalítica. A 
ligação uPA-uPAR induz mudanças conformacionais no complexo, as quais iniciam cascatas de sinalização interna que afetam a proliferação celular, dinâmica do citoesqueleto e adesão celular (Bhattacharya et al., 2012; Lahteenmaki et al., 2001; Rijken, 1995).

\subsubsection{Ativadores bacterianos de plasminogênio}

Algumas bactérias patogênicas como Streptococcus e Staphylococcus também secretam ou exibem em sua membrana proteínas que atuam como ativadores de plasminogênio. A estreptoquinase (STK) e estafiloquinase (SAK) formam complexos 1:1 com o plasminogênio e plasmina causando mudanças na sua conformação e especificidade e atuando, portanto, como ativadores do plasminogênio (Bhattacharya et al., 2012; Lahteenmaki et al., 2001; Parry et al., 2000). A SAK produzida por Streptococcus aureus ativa plasminogênio preferencialmente quando este se encontra ligado à fibrina; geralmente o complexo ativo só é formado com a plasmina. Contrariamente ao que ocorre com STK, o complexo SAK-plasmina é eficientemente inibido pela $\alpha_{2}$-anti-plasmina (Molkanen et al., 2002 ). SAK e STK são também usadas como farmacoterápicos com ação trombolítica em tratamentos clínicos de infarto agudo do miocárdio e trombose arterial (Collen, 1998; Sakharov et al., 1996).

\subsubsection{Inibidores dos ativadores de plasminogênio (PAIs)}

Entre os mais importantes inibidores de ativadores de plasminogênio estão o PAI-1 e PAI-2, da família das serino proteases (serpinas). O PAI-1 é uma glicoproteína de 52 kDa, sintetizada por células endoteliais, células musculares lisas, hepatócitos, entre outras. Sua concentração no plasma é 10 a $30 \mathrm{ng} / \mathrm{ml}$. O PAI-2 está presente em duas formas diferentes: uma intracelular glicosilada de $47 \mathrm{kDa}$ e outra forma glicosilada secretada de $60 \mathrm{kDa}$. A inibição observada da atuação do plasminogênio no plasma humano é feita exclusivamente pelo PAI-1. Sua atividade reguladora é exercida sobre o tPA e uPA. O PAI-1 inibe o tPA ao ligar-se ao seu centro catalítico, o que favorece a formação de complexos (tPA-PAI-1) sobre as moléculas de fibrina que, além de serem inativadas, também competem com outros ativadores de plasminogênio pelos sítios de ligação à fibrina. Este sistema diminui de forma eficiente o efeito fibrinolítico (Lahteenmaki et al., 2001; Rijken, 1995). 


\subsubsection{Inibidor da plasmina: $\alpha_{2}$-antiplasmina}

É uma glicoproteína de $67 \mathrm{kDa}$, sua concentração plasmática é aproximadamente 70 ng/ml. Atua como o principal inibidor fisiológico da plasmina, tanto no sangue quanto nos tecidos. O mecanismo de inibição consiste na formação de um complexo com proporção estequiométrica 1:1 com o centro ativo da enzima. A reação, que é realmente rápida, depende da disponibilidade dos sítios de ligação na lisina: é necessário que estes se encontrem livres no plasminogênio. Uma vez que o plasminogênio se une à fibrina, a reação é 100 vezes menos eficiente (Lahteenmaki et al., 2001; Parry et al., 2000).

\subsection{Sistema Complemento e fibrinólise na eliminação de patógenos}

As doenças infecciosas têm representado para a humanidade ao longo do tempo um importante problema de saúde, estreitamente relacionado com diversos aspectos sociais e econômicos de cada país. No mundo inteiro, diferentes pesquisas são direcionadas ao entendimento, controle, erradicação ou implementação de novas terapias que diminuam os índices de prevalência destas doenças.

$\mathrm{Na}$ defesa do hospedeiro e controle da infecção, a importância do sistema complemento pode ser nitidamente observada quando algumas das suas funções são comprometidas, como resultado de alguma deficiência genética ou interferência patológica. Neste caso, deficiências de componentes do complemento são geralmente associadas com maior susceptibilidade às infecções. Uma vez que o sistema complemento co-evoluiu com os patógenos durante milhões de anos, não é uma surpresa encontrar micro-organismos que desenvolveram diversos mecanismos para inibir a ativação deste sistema e suas funções efetoras (Dunkelberger, Song, 2010).

O sistema complemento pode ser ativado em pouco tempo sobre a superfície de microorganismos. Patógenos mais bem adaptados e mais virulentos desenvolveram múltiplas e sofisticadas estratégias de evasão ao sistema complemento que acabam por interferir na ativação deste sistema e nas suas funções biológicas, normalmente bastante eficazes contra micro-organismos menos virulentos. Entre os mecanismos melhor descritos, têm sido bastante investigados: a) a aquisição de proteínas reguladoras do hospedeiro como FH e C4BP. Tais reguladores impedem a ativação do sistema complemento sobre a superficie bacteriana; b) expressão de proteínas com capacidade reguladora semelhante à do hospedeiro; d) produção de proteases que inibem a formação de C3-convertases e C5-convertases; e, e) sequestro de 
proteases produzidas pelo hospedeiro como trombina e plasminogênio que conseguem inibir o sistema complemento pela clivagem de C3b e C5 (Barthel et al., 2012).

$\mathrm{Na}$ leptospirose, o sistema complemento é importante para o controle da infecção por espécies não patogênicas. Alguns estudos têm demostrado que a virulência de estirpes patogênicas está relacionada com sua capacidade de sobreviver na presença do soro, pois, uma vez que penetram no hospedeiro, leptospiras não patogênicas são rapidamente eliminadas da corrente sanguínea. Já as patogênicas, quando presentes em grande número, são capazes de sobreviver, multiplicar e desencadear uma resposta imune específica (Faine et al., 1999). Isto se deve, basicamente, a dois mecanismos: a habilidade de escapar do sistema fagocitário e sistema complemento (Barbosa et al., 2009; Cinco, Banfi, 1983; Cinco et al., 2002; Meri et al., 2005) e a capacidade que estes organismos apresentam de aderir a células eucariotas e a proteínas da matriz extracelular (Ballard et al., 1986; Barbosa et al., 2006; Choy et al., 2007; Merien et al., 2000; Thomas, Higbie, 1990; Tsuchimoto et al., 1984; Vinh et al., 1984).

Há vários anos, relatou-se a aquisição de $\mathrm{FH}$ do soro humano por leptospiras patogênicas (Meri et al., 2005) e, em 2009, nosso grupo mostrou que as estirpes patogênicas L. interrogans, L. kirshneri, L. borgpetersenii e L. noguchi são capazes de interagir também com C4BP e que esta molécula, uma vez ligada à membrana da bactéria, retém atividade de co-fator de FI, uma serinoprotease ativa no soro do hospedeiro e responsável pela clivagem de C4b. Também foi demostrado que os componentes C6, C7, C8 e C9, integrantes do MAC, depositam-se em maiores quantidades na superfície da estirpe não-patogênica (Barbosa et al., 2009).

A habilidade de leptospiras patogênicas de penetrar, disseminar e persistir nos tecidos do hospedeiro sugere uma atuação importante de mecanismos de evasão imune. Em outras bactérias espiroquetas (gênero Borrelia), inúmeras lipoproteínas conhecidas como complement regulator-acquiring surface proteins (CRASPs) são capazes de se ligar a FH e/ou a FHL-1 (Kraiczy et al., 2004; Wallich et al., 2005). Treponema denticola também expressa uma proteína que interage com $\mathrm{FH}(\mathrm{FhbB})$ e assim escapa da morte pela ativação da via alternativa do complemento (Miller et al., 2012). As leptospiras patogênicas interagem com diversos componentes de matriz extracelular como laminina, colágeno tipo I e IV, fibronectina, elastina e proteoglicanos (Breiner et al., 2009; Barbosa et al., 2006; Choy et al., 2007; Ito, Yanagawa,1987; Lin et al., 2009). Cabe ressaltar que leptospiras patogênicas são micro-organismos altamente invasivos, capazes de aderir e invadir células hospedeiras mais eficientemente do que as estirpes não patogênicas e saprófitas (Fraga et al, 2011; Liu, 2007). Embora a aquisição de proteínas reguladoras do sistema complemento como FH (Meri et al. 
2005) e C4BP (Barbosa et al., 2009) tenha sido observada em leptospiras patogênicas, muito pouco se conhece sobre a natureza dos ligantes bacterianos que participam destas interações. Até o início deste trabalho, somente as proteínas de membrana de Leptospira (LenA e LenB) (Stevenson et al., 2007; Verma et al., 2006) haviam sido descritas com capacidade de se ligar ao FH, e apenas as proteínas LcpA (Barbosa et al., 2010), Lsa33 (Domingos et al., 2012) e Lsa30 (Souza et al., 2012) mostraram interação com C4BP.

Algumas bactérias como Porphyromonas gingivalis, Pseudomonas aeruginosa e Clostridium perfringens produzem enzimas proteolíticas que podem digerir a matriz extracelular e facilitar sua invasão. Outras como Borrelia burgdorferi e Borrelia crocidurae fazem uso do sistema fibrinolítico do hospedeiro para invadir os tecidos (Coleman et al., 1997; Nordstrand et al., 2001). Algumas espiroquetas ligam-se ao plasminogênio do hospedeiro que subsequentemente é processado pelo ativador de plasminogênio tipo uroquinase (uPA) gerando plasmina, uma enzima que atua como serino protease na degradação de componentes de matriz extracelular (Coleman et al., 1997; Fuchs et al., 1994; Grab et al., 2005). Os sistemas complemento e da coagulação geralmente são descritos como sistemas separados, mas ambos são formados por serino proteases que possuem características estruturais similares, e também atuam ao mesmo tempo no processo inflamatório. Em 2010 foi descrito que o fator de coagulação XIIa, também uma serino protease, pode ativar C1r e iniciar a ativação da via clássica do complemento. Outras proteínas como a trombina e a plasmina são capazes de clivar C5 na ausência de C3, sugerindo que estas serino proteases do sistema da coagulação e fibrinolítico possam contribuir para a ativação do complemento de uma forma não convencional (Amara et al., 2010). Embora algumas proteases do sistema de coagulação contribuam para ativar o sistema complemento, estas proteases também poderiam regulá-lo, o que nos levou a investigar a função da plasmina na clivagem de proteínas do complemento como mecanismo de evasão empregado por leptospiras patogênicas (Figura 11). 
Figura 11 - Plasminogênio controla as vias de ativação do sistema complemento em diferentes etapas.

\section{Complemento}

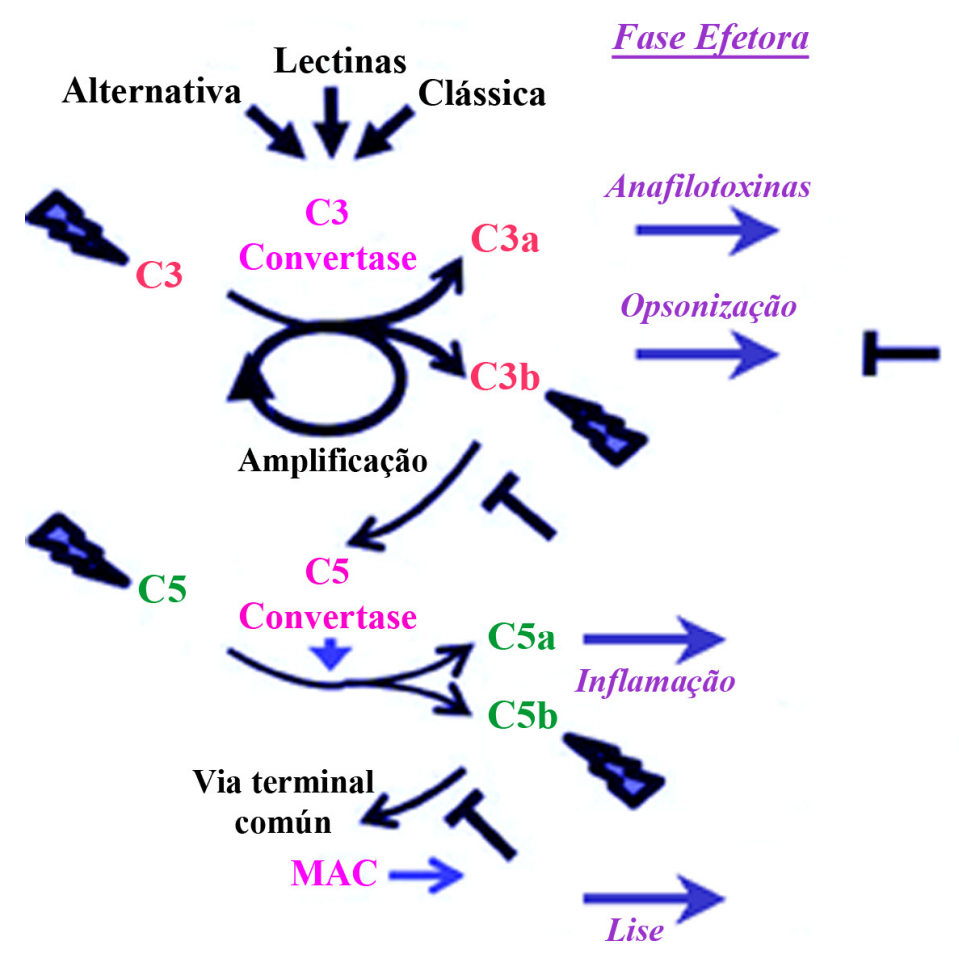

\section{Coagulação}

Plasminogênio
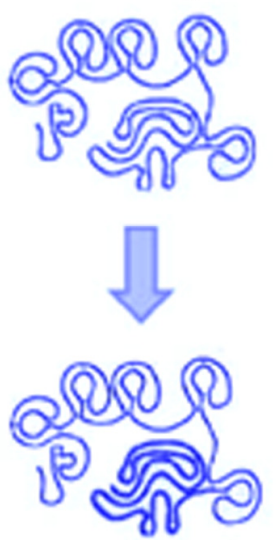

Plasmina

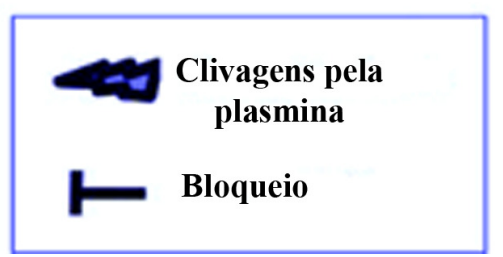

Plasminogênio quando convertido em plasmina afeta as vias de ativação do complemento em diferentes etapas. A plasmina pode clivar C3 e C5, componentes centrais das três vias. Alem disso, a plasmina também consegue clivar C3b e C5b e, consequentemente, bloqueia a ativação das três vias do complemento. Com isso, funções importantes do sistema complemento como opsonização e lise são também bloqueadas (Adaptado de Barthel et al., 2012).

Diversos estudos têm proposto que a interação de proteínas de membrana com plasminogênio também seja importante para a capacidade invasiva de um grande número de patógenos (Coleman et al., 1995; Fuchs et al., 1996; Klempner et al., 1996; Kunert et al., 2007). Alguns estudos mostram que reguladores do complemento podem competir com plasminogênio por sítios de interação em receptores bacterianos (Kunert et al., 2007, Rossmann et al., 2007). Recentemente, alguns estudos mostraram que leptospiras interagem com plasminogênio, e que esta ligação ocorre principalmente por resíduos de lisina, uma vez que a interação pode ser inibida pela adição de ácido aminocapróico (Vieira et al., 2009, 2010). Também foi demonstrado que o plasminogênio ligado à leptospira pode ser ativado em plasmina na presença de uPA. As proteínas de membrana de leptospira que até o momento mostraram interação com plasminogênio foram LipL32, rLIC12730, rLIC10494, Lp29, Lp49, Lp40, MPL36, rLIC12238 (Vieira et al., 2010) e LenA (Verma et al., 2010), OmpA-like (Oliveira et al., 2011), Lsa20 (Mendes et al., 2011), OmpL-1 (Fernandes et al., 2012), Lsa23, 
Lsa26, e Lsa36 (Siqueira et al., 2013), EF-Tu (Wolff et al., 2013), enolase (LA1951) (Nogueira et al., 2013) Lsa44 e Lsa45 (Fernandes et al., 2014).

Há relatos que atribuem ao plasminogênio (e indiretamente à plasmina, sua forma ativa) ligado à superfície do patógeno a capacidade de degradação de C3b (Rooijakkers et al., 2005; Rossmann et al., 2007). O sequestro de plasminogênio por parte do patógeno permite que a plasmina atue sobre o fragmento $\mathrm{C} 3$ b clivando-o, escapando assim da ação do sistema complemento. Bacillus anthracis utiliza este mecanismo para escapar da ação do complemento (Chung et al., 2011). O plasminogênio ligado às proteínas da membrana externa deste micro-organismo gera plasmina que, por sua vez, cliva $\mathrm{C} 3 \mathrm{~b}$, reduzindo a possibilidade de opsonização. Recentemente, o plasminogênio foi apresentado como um novo inibidor do sistema complemento, uma vez que convertido em plasmina consegue clivar C3b e C5 em diferentes fragmentos, bloqueando assim as três vias de ativação do complemento humano (Barthel et al., 2012).

Dada a escassez de dados na literatura concernentes à caracterização de fatores relacionados à patogênese da leptospirose, este projeto de pesquisa teve como objetivo investigar proteínas de membrana de L. interrogans envolvidas no processo de evasão ao sistema imune, com particular enfoque na interação com FH e C4BP, dois importantes reguladores do sistema complemento do hospedeiro, e também com plasminogênio como inibidor da ativação do complemento.

\subsection{Ativação de polimorfonucleares (PMN)}

Outro mecanismo importante na eliminação dos patógenos é a fagocitose. Os polimorfonucleares são integrantes importantes da imunidade, e suas atividades são essenciais para a resolução de infecções. Interações fagócito-patógeno geralmente desencadeiam um variado número de respostas anti-microbianas, que levam à morte altamente eficiente de patógenos. O processo fagocitário depende da fusão do fagossomo com lissosomos formando o fagolisossomo pode matar os micro-organismos pela ação das enzimas líticas lisossomais e das espécies reativas de oxigênio (Park, 2003).

A explosão respiratória representa uma das principais funções anti-microbianas apresentada pelos neutrófilos e outras células fagocitárias. Em pessoas saudáveis é provável que a explosão respiratória não somente participe da morte de espiroquetas como também desempenhe uma função importante na ativação da imunidade inata (Suhonen et al., 2000). A mobilização de cálcio intracelular é o primeiro evento causado pela interação dos receptores 
com seus ligantes. O cálcio livre afeta as vias de sinalização internas que participam na indução da explosão respiratória e fagocitose (Discipio et al., 1998; Lew et al., 1985; Suhonen et al., 2000). O CR3 é um dos receptores de complemento envolvidos com a ativação de fagócitos que acabam por gerar espécies reativas de oxigênio (Park, 2003). O CR3 é uma integrina heterodimérica formada pela subunidade $\alpha(\mathrm{CD} 11 \mathrm{~b})$ e a subunidade $\beta$ (CD18), associadas não covalentemente entre si. O CR3 é encontrado na membrana plasmática de polimorfonucleares (PMNs) como neutrófilos, basófilos e eosinófilos, mas também presente em monócitos/macrófagos, células NK e células dendríticas foliculares (Cinco et al., 2002; Roskamp et al., 2005). A estimulação de CR3 na primeira fase resulta na fosforilação de tirosina e de diversas proteínas endógenas, a ativação das fosfolipasas A2 e D e NADPH oxidase. Este receptor está envolvido em interações célula-célula, com componentes de matriz extracelular como fibronectina, além de aderir aos componentes C3b, iC 3b do sistema complemento (Agarwal et al., 2010). Atualmente é conhecido que CR3 interage com FH principalmente pelos domínios SCRs 6, 7 e 18 a 20 (Agarwal et al., 2010; Discipio et al., 1998).

A fagocitose de leptospiras acontece na presença de soro humano mesmo na ausência de anticorpos específicos (Cinco, Banfi, 1983). Cinco et al. (2002) demostraram que leptospiras patogênicas e não patogênicas ligam-se a fagócitos na ausência de anticorpos específicos via CR3. Em consequência disso, a molécula de FH que também interage com leptospiras e com alguns patógenos poderia facilitar a adesão destes aos fagócitos. Este processo foi demonstrado em Candida albicans (Losse et al., 2010) e Neisseria gonorrhoeae (Agarwal et al., 2010). A adesão de FH a neutrófilos aumenta a secreção de peróxido de hidrogênio e lactoferrina (Discipio et al., 1998). Portanto, FH poderia contribuir para a interação do patógeno com o fagócito via CR3, provocando sua ativação e promovendo a fagocitose.

Neutrófilos representam a primeira linha de defesa contra patógenos e são rapidamente atraídos em grande número aos locais de inflamação. Já é conhecido que FH interage com CR3 para ativação de neutrófilos e participando assim da fagocitose de Candida albicans via CR3 (Losse et al., 2010). Uma vez que a interação das leptospiras com FH mostrou ser importante para a sobrevivência na presença do complemento (Castiblanco-Valencia et al., 2012) e que CR3 é um receptor importante na ativação de PMN e interage com FH, investigamos neste estudo se este regulador também poderia ter alguma função mediando a interação entre leptospira e fagócito via CR3. 


\section{OBJETIVOS}

\subsection{Objetivo geral}

Avaliar a interação de proteínas recombinantes de Leptospira interrogans com reguladores do sistema complemento e plasminogênio do hospedeiro, investigando o papel destas proteínas na evasão deste patógeno à atividade do sistema complemento.

\subsection{Objetivos específicos}

1. Identificar proteínas recombinantes de Leptospira envolvidas no processo de evasão imune, investigando sua interação com FH e C4BP;

2. Caracterizar as interações protéicas quanto à especificidade e afinidade de ligação a FH e/ou C4BP;

3. Investigar a atividade reguladora de FH e C4BP após interação com as proteínas;

4. Confirmar a interação LigA e LigB com plasminogênio;

5. Avaliar a atividade do plasminogênio/plasmina ligado as proteínas recombinantes de interesse sobre proteínas do sistema complemento;

6. Avaliar a possível competição entre o plasminogênio e os reguladores do complemento $\mathrm{FH}$ e C4BP por sítios de ligação às proteínas LigA e LigB;

7. Investigar a interação de leptospiras patogênicas previamente incubadas com FH com polimorfonucleares humanos. Em particular, analisaremos a participação de receptores de complemento neste processo. 


\section{MATERIAL E MÉTODOS}

3.1 Seleção das proteínas recombinantes de Leptospira interrogans sorovar Copenhageni

Para identificar algumas das proteínas de membrana de leptospira que interagem com os reguladores do complemento $\mathrm{FH}$ e $\mathrm{C} 4 \mathrm{BP}$, priorizamos estudar proteínas presentes nas espécies patogênicas e ausentes nas saprófitas, supostamente localizadas na membrana da bactéria (Tabela 1). A predição bioinformática da localização celular dessas proteínas foi feita pelo programa PSORT (Naka, Kanehisa, 1991). Além disso, dados na literatura referentes às características e funções biológicas conhecidas de algumas dessas proteínas contribuíram para sua escolha neste trabalho.

Tabela 1 - Nomenclatura das proteínas recombinantes de Leptospira interrogans utilizadas neste estudo, incluindo o número de acesso no Genbank e características gerais.

\begin{tabular}{cccc}
\hline $\begin{array}{c}\text { Nomenclatura dos } \\
\text { genes (LIC) }\end{array}$ & $\begin{array}{c}\mathbf{N}^{\mathbf{0}} \text { de acesso } \\
\text { (NCBI) }\end{array}$ & Característica & $\begin{array}{c}\text { Massa molecular da } \\
\text { proteína (kDa) }\end{array}$ \\
\hline (a) LIC10009 & AAS68646 & Lipoproteína (provável) & 27 \\
\hline (a) LIC10704 & AAS69325 & Lipoproteína (provável) & 24 \\
\hline (b) LIC10657 & AAS69278 & Esfingomielinase & 59 \\
\hline (a) LIC10301 & AAS68928 & Lipoproteína (provável) & 13 \\
\hline (a) LIC11087 & AAS69694 & Lipoproteína (provável) & 32 \\
\hline (a) LIC10507 & AAS69128 & Lipoproteína (provável) & 23 \\
\hline $\begin{array}{c}\text { (a,d) } \text { LIC10465 } \\
\text { LigAC }\end{array}$ & AAS69086 & $\begin{array}{c}\text { Proteína de superfície } \\
\text { com domínios Ig-like }\end{array}$ & 63 \\
\hline $\begin{array}{c}\text { (d) } \text { LIC10464 } L i g B C \\
\text { (d) } \text { LIC10464 }\end{array}$ LigBN & AAS69085 & $\begin{array}{c}\text { Proteína de superfície } \\
\text { com domínios Ig-like }\end{array}$ & 56 \\
\hline (b) LIC10325 & AAS69085 & $\begin{array}{c}\text { Proteína de superfície } \\
\text { com domínios Ig-like }\end{array}$ & 64 \\
\hline (b) LIC11352 & AAS68952 & Hemolisina & 42 \\
LipL32 & AAS69953 & Lipoproteína & 28 \\
\hline (b) LIC13143 & AAS71688 & Hemolisina & 33 \\
\hline (c) LIC11030 & AAS69637 & Lipoproteína (provável) & 37 \\
\hline (b) LIC12631 & AAS71191 & Esfingomielinase & 71 \\
\hline
\end{tabular}

Proteínas recombinantes purificadas pela equipe da Dra. Patrícia Abreu (a), do Dr. Paulo Lee Ho (b) e da Dra. Angela Barbosa (c) do Instituto Butantan. Proteínas que purifiquei para este trabalho (d). 


\subsection{Vetores Utilizados}

Para a clonagem dos produtos amplificados pela reação em cadeia empregando DNA polimerase (PCR) utilizamos o vetor pGEM-T Easy (Promega) (Figura 12). Para expressão das proteínas recombinantes foi utilizado o vetor pAE (Figura 13).

Figura 12 - Representação do vetor $p G E M-T$ Easy (Promega).

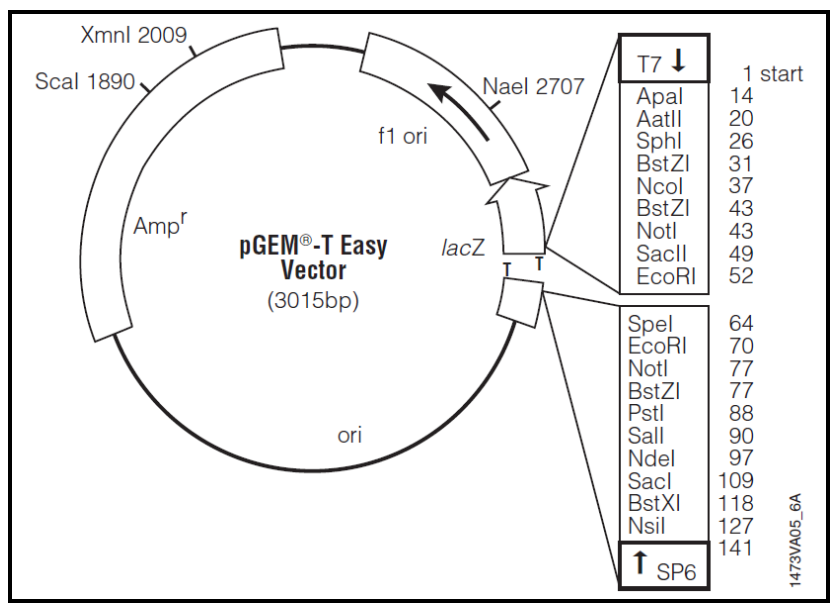

Este vetor é derivado do plasmídeo pGEM-5Zf(+), e contem timinas nas extremidades 3'. Vetor utilizado para clonagem dos produtos da PCR. Contém múltiplos sítios de clonagem (SMC) permitindo a liberação do inserto usando a enzima de restrição apropriada.

Figura 13 - Representação do vetor pAE



O vetor pAE, utilizado para expressão de proteínas em E. coli foi construído a partir dos plasmídeos pRSET e pET3-His. O vetor possui promotor do fago T7(T7), sítio de ligação ao ribossomo (RBS), sítios para múltiplas clonagens (SMC), terminador de transcrição (term) e sequência codificadora para $\beta$-lactamase que confere resistência à ampicilina (AMP). Possui uma região codificadora para 6 resíduos de histidina (His) na extremidade amino-terminal da proteína recombinante que permite a sua posterior purificação por cromatografia de afinidade. (Ramos et al., 2004). 
3.3 Linhagens bacterianas empregadas nas clonagens

E. coli DH5- $\alpha$ : bactéria utilizada para clonagem de fragmentos e obtenção de grande quantidade de plasmídeos. Os clones positivos foram selecionados após crescimento das colônias em meio contendo o substrato 5-bromo-4-chloro-3-indolyl-beta-Dgalactopyranoside (X-gal).

E. coli BL21 (SI): E. coli utilizada para expressão de proteínas recombinantes após indução com $\mathrm{NaCl}$.

3.4 Preparação de bactérias competentes

As bactérias E. coli (cepas DH5- $\alpha$ e BL21) foram preparadas após tratamento com $\mathrm{MgCl}_{2} 1 \mathrm{M}$, que induz um estado transitório de competência, fragilizando as paredes das células e tornando-as competentes para transformação com plasmídeos após choque térmico.

Uma colônia de bactérias previamente estriadas em placas contendo meio LB-ágar (triptona $1 \%$, extrato de levedura $0,5 \%$ e $\mathrm{NaCl} 1 \%$, agar 10\%) foi inoculada em $5 \mathrm{~mL}$ de meio $\mathrm{LB}$ (triptona $1 \%$, extrato de levedura $0,5 \%$ e $\mathrm{NaCl} 1 \%$ ) e incubada por $16 \mathrm{~h}$ a $37^{\circ} \mathrm{C}$. Após este período, este pré-inóculo foi transferido para $100 \mathrm{~mL}$ de meio $\mathrm{LB}$ e incubado sob agitação a $37^{\circ} \mathrm{C}$ por um período de 2 a $3 \mathrm{~h}$, até que a densidade óptica da cultura atingisse 0,6 a $600 \mathrm{~nm}$ $\left(\mathrm{DO}_{600}\right)$, indicativo de crescimento bacteriano em fase logarítmica. Neste momento, o inóculo foi resfriado no gelo quando recebeu $1 \mathrm{ml}$ de solução de $\mathrm{MgCl}_{2} 1 \mathrm{M}$. Após $15 \mathrm{~min}$, o inóculo foi centrifugado a $1620 \mathrm{~g}$ por $15 \mathrm{~min}$ a $4{ }^{\circ} \mathrm{C}$. O precipitado foi lavado 2 vezes com $20 \mathrm{~mL}$ de solução RF I (acetato de potássio $30 \mathrm{mM}, \mathrm{CaCl}_{2} 10 \mathrm{mM}, \mathrm{MnCl}_{4} 50 \mathrm{mM}, \mathrm{KCl} 100 \mathrm{mM}$, glicerol $15 \%$, pH 5,8) a $1620 \mathrm{~g}$ por $15 \mathrm{~min}$ a $4{ }^{\circ} \mathrm{C}$ e ressuspendido em $2 \mathrm{~mL}$ de solução RF II $\left(\mathrm{CaCl}_{2} 75 \mathrm{mM}, \mathrm{MgCl}_{2} 20 \mathrm{mM}, \mathrm{KCl} 10 \mathrm{mM}\right.$, MOPS $10 \mathrm{mM}$, glicerol 15\%, pH 6,8), aliquotado em frações de $50 \mu \mathrm{L}$, congelado e estocado a $-80^{\circ} \mathrm{C}$.

\subsection{Amplificação dos genes por PCR}

As sequências gênicas LIC10464 e LIC10465 foram amplificadas por PCR a partir do DNA genômico de L. interrogans sorovar Copenhageni cepa L1-130 com oligonucleotídeos sintéticos (iniciadores) contendo sítios de restrição apropriados (Tabela 2), e condições descritas nas Tabelas 3 e $\mathbf{4}$. As bandas correspondentes aos produtos amplificados foram 
visualizadas sob luz UV, após eletroforese em gel de agarose $1 \%$ em tampão TAE (Tris 80 $\mathrm{mM}$, acido acético glacial $40 \mathrm{mM}$, EDTA 2,5 mM, pH 8,5), corado com brometo de etídio.

Tabela 2 - Sequências dos oligonucleotídios

\begin{tabular}{|c|c|c|c|c|}
\hline $\begin{array}{c}\begin{array}{c}\text { Nomenclatura } \\
\text { dos genes } \\
\text { (LIC) }\end{array} \\
\end{array}$ & Iniciadores & Sequência & Utilizados em & $\begin{array}{c}\text { Inserto } \\
\text { (pb) }\end{array}$ \\
\hline \multirow{5}{*}{$L I C 10465$} & & & PCR & \multirow[t]{5}{*}{1803} \\
\hline & LigAC UF & 5'-GGATCCCTTACCGTTTCCAACACAAACG-3' & & \\
\hline & LigAC UR & 5'-CCATGGTTACTCGAGTGGCTCCGTTTTAATAG-3' & & \\
\hline & LigAC int-F & 5'-CTGCTACAGGTATCTACTCTG-3' & \multirow[t]{2}{*}{ Sequenciamento } & \\
\hline & LigAC int-R & 5'-CGATTGCAATGTTGGATGGC-3' & & \\
\hline \multirow{4}{*}{ LIC10464 } & LigBC UF & 5'-CTCGAGGCTGAAATTAAAAATACC-3' & PCR & \multirow{4}{*}{1593} \\
\hline & LigBC UR & 5'-GAAGCTTTTAGGATAAATCAAGGG-3' & & \\
\hline & LigBC int-F & 5'-CTTCTATCGAGATAACACCGAC-3' & Sequenciamento & \\
\hline & LigBC int-R & 5'-GCTGCGCTGACCGTTATGTC-3' & & \\
\hline \multirow{4}{*}{$\begin{array}{l}\text { LIC10464 } \\
\text { LIC10465 }\end{array}$} & LigBN UF & 5'-CCTCGAGGGTCTGGTAGGATTACC-3' & PCR & \multirow[t]{4}{*}{1831} \\
\hline & LigBN UR & 5'-CCATGGCTAAATATCCGTATTAGAGG-3' & & \\
\hline & LigBN int-F & 5'-CGGATGGTTCTCATCAGGA-3' & \multirow[t]{2}{*}{ Sequenciamento } & \\
\hline & LigBN int-R & 5'-GAGAACCGCAGGAACTACAG-3' & & \\
\hline \multirow[b]{2}{*}{ pGEM-T } & M13 F & 5'-GTTTTCCCAGTCACGAC-3' & Sequenciamento & \\
\hline & M13 R & 5'-CAGGAAACAGCTATGAC-3' & Sequenciamento & \\
\hline
\end{tabular}

Tabela 3 - Reação de amplificação dos genes por PCR.

\begin{tabular}{lccc}
\hline \multicolumn{1}{c}{ Componente } & $\begin{array}{c}\text { Concentração } \\
\text { Inicial }\end{array}$ & Volume & $\begin{array}{c}\text { Concentração } \\
\text { final }\end{array}$ \\
\hline $\begin{array}{l}\text { DNA } \\
\text { L. interrogans sorovar Copenhageni }\end{array}$ & $50 \mathrm{ng}$ & $1,0 \mu \mathrm{l}$ & - \\
\hline Tampão de reação 10X & $10 \mathrm{X}$ & $5,0 \mu \mathrm{l}$ & $1 \mathrm{X}$ \\
\hline Cloreto de magnésio & $50 \mathrm{mM}$ & $1,5 \mu \mathrm{l}$ & $1,5 \mathrm{mM}$ \\
\hline Iniciador 5 & $10 \mu \mathrm{M}$ & $1,0 \mu \mathrm{l}$ & $0,2 \mu \mathrm{M}$ \\
\hline Iniciador 3 & $10 \mu \mathrm{M}$ & $1,0 \mu \mathrm{l}$ & $0,2 \mu \mathrm{M}$ \\
\hline dNTPs & $10 \mathrm{mM}$ & $1,0 \mu \mathrm{l}$ & $0,2 \mathrm{mM}$ \\
\hline Taq DNA polimerase & $5 \mathrm{U} / \mu \mathrm{l}$ & $0,5 \mu \mathrm{l}$ & $0,05 \mathrm{U} / \mu \mathrm{l}$ \\
\hline Água MilliQ estéril & - & $39 \mu \mathrm{l}$ & - \\
\hline
\end{tabular}

Consideramos $50 \mu \mathrm{l}$ como volume final de reação.

Tabela 4 - Condições da PCR (35 ciclos)

\begin{tabular}{lcc}
\hline & Temperatura ${ }^{\circ} \mathbf{C}$ & Tempo \\
\hline 1. Desnaturação inicial & 94 & $5 \mathrm{~min}$ \\
\hline 2. Desnaturação & 94 & $50 \mathrm{~s}$ \\
\hline 3. Anelamento dos iniciadores & $55-58$ & $50 \mathrm{~s}$ \\
\hline 4. Extensão & 72 & $2 \mathrm{~min}$ \\
\hline 5. Extensão final & 72 & $7 \mathrm{~min}$ \\
\hline
\end{tabular}


3.6 Clonagem dos insertos no vetor pGEM-T e transformação de bactérias competentes por choque térmico

Os fragmentos amplificados e purificados a partir de géis de agarose a $1 \%$ foram primeiramente clonados no vetor pGEM-T (Promega). Na reação de ligação, graças à ação da T4 DNA ligase, o inserto foi inserido no vetor e $2 \mu$ l dessa reação foram usados para a transformação das bactérias competentes E. coli $\mathrm{DH} 5 \alpha$. Esta técnica permite a introdução de plasmídeos em bactérias e sua manutenção como um elemento autônomo autorreplicativo. Suspensões de bactérias quimicamente competentes foram descongeladas no gelo por $15 \mathrm{~min}$, e em seguida foram adicionados 1 a $5 \mu \mathrm{l}$ de plasmídeo $(50 \mathrm{ng})$ e mantidas no gelo por $30 \mathrm{~min}$. Após este período, as bactérias foram submetidas a choque térmico a $42{ }^{\circ} \mathrm{C}$ por 2 min, seguido por um tempo de incubação de $5 \mathrm{~min}$ no gelo. Posteriormente, foram adicionados 450 $\mu \mathrm{L}$ de meio de cultura LB e a suspensão de bactérias foi mantida sob agitação a $37^{\circ} \mathrm{C}$ por 90 min. Finalmente, as bactérias foram incubadas a $37^{\circ} \mathrm{C}$ por $16 \mathrm{~h}$ em placas de meio LB-ágar contendo $50 \mu \mathrm{g} / \mathrm{mL}$ de $\mathrm{X}$-gal e $100 \mu \mathrm{g} / \mathrm{mL}$ de ampicilina.

As colônias resistentes à ampicilina foram selecionadas e analisadas por PCR para confirmação da presença dos insertos. Os plasmídeos contendo os insertos foram extraídos e purificados utilizando kits de mini-preparação (Promega, Qiagen). A sequência correta dos insertos em pGEM-T Easy foi confirmada por sequenciamento.

3.7 Clonagem dos insertos no vetor de expressão pAE e transformação de bactérias competentes por choque térmico

As construções obtidas foram digeridas com as enzimas de restrição apropriadas (Tabela 5) para a obtenção dos insertos de interesse. O vetor pAE também foi digerido com essas enzimas, para que os respectivos sítios de restrição fossem usados nas reações de ligação. Após digestão enzimática, os insertos e vetores foram aplicados em gel de agarose $1 \%$ para visualização da eficiência da digestão. Foram feitas três construções contendo os fragmentos de Ligs (LigAC-pAE, LigBC-pAE e LigBN-pAE), responsáveis pelas porções Cterminais das proteínas LigA e LigB e à porção N-terminal comum a ambas.

$\mathrm{Na}$ reação de ligação foram utilizados $1 \mu \mathrm{L}$ de T4 DNA Ligase, $5 \mu \mathrm{L}$ de Tampão Rapid Ligation $2 \mathrm{X}$ e quantidades otimizadas de inserto e vetor no volume final de $30 \mu 1$. A reação foi incubada por $16 \mathrm{~h}$ a $4{ }^{\circ} \mathrm{C}$. Após este período, $2 \mu \mathrm{L}$ da reação foram utilizados para a 
transformação de bactérias competentes $E$. coli $\mathrm{BL} 21(\mathrm{SI})$ por choque térmico $\left(5\right.$ min a $4{ }^{\circ} \mathrm{C}$ no gelo; $50 \mathrm{~s} \mathrm{a} 42{ }^{\circ} \mathrm{C}$; e finalmente 2 min a $4{ }^{\circ} \mathrm{C}$ no gelo). A clonagem dos insertos no vetor pAE foi confirmada após sequenciamento de nucleotídeos. As colônias de interesse foram coletadas e estocadas em $40 \%$ glicerol a $-80{ }^{\circ} \mathrm{C}$ para uso posterior.

Tabela 5 - Enzimas de restrição utilizadas na digestão dos plasmídeos.

\begin{tabular}{cc}
\hline Enzimas de restrição & Construção plasmidial \\
- BamHI e NcoI & LigAC \\
- XhoI e HindIII & LigBC \\
- XhoI e $N c o$ I & LigBN \\
\hline
\end{tabular}

\subsection{Sequenciamento de DNA}

A análise da sequência de DNA dos plasmídeos e dos fragmentos de DNA amplificados por PCR foi feita pelo método de Sanger (Sambrook et al., 1989), adaptado para seqüenciador automático capilar ABI3100 (Perkin Elmer), do Centro de Biotecnologia, Instituto Butantan.

O sequenciamento de nucleotídeos foi feito utilizando-se $150 \mathrm{ng}$ das mini-preparações de DNA plasmidial obtidas por kits de extração (Invitrogen) e 1,6 pmol de iniciadores em água Milli-Q autoclavada. Empregou-se o kit BigDye Terminator, Perkin Elmer, segundo protocolo do fabricante.

Os insertos clonados no vetor pGEMT-Easy foram sequenciados com os iniciadores M13F, M13R; os insertos clonados em pAE foram sequenciados com iniciadores 5' e iniciadores internos (Tabela 2).

\subsection{Expressão de proteínas recombinantes}

Para expressar as proteínas recombinantes, colônias isoladas das cepas competentes de E. coli BL21(SI) previamente transformadas com as diversas construções foram inoculadas em $30 \mathrm{ml}$ de meio LB-ampicilina. A cultura foi incubada a $37^{\circ} \mathrm{C}$ sob agitação por $18 \mathrm{~h}$. Após esse período de incubação, foram adicionados $370 \mathrm{ml}$ de meio LB-ampicilina e a cultura foi incubada a $37{ }^{\circ} \mathrm{C}$ sob agitação até atingir $\mathrm{DO}_{600 \mathrm{~nm}}=0,6$. Uma amostra de cada cultura foi coletada antes da indução para ser usada como controle (controle não induzido). Neste 
momento, foi adicionado $\mathrm{NaCl}$ na concentração final $60 \mathrm{mM}$ como agente indutor. Em seguida, a cultura com o agente indutor foi incubada por mais $3 \mathrm{~h}$ a $37{ }^{\circ} \mathrm{C}$.

Após esse período, a cultura foi centrifugada a $2880 \mathrm{~g}$ por $15 \mathrm{~min}$ a $4{ }^{\circ} \mathrm{C}$. O sobrenadante foi descartado e o precipitado armazenado a $-20^{\circ} \mathrm{C}$. A indução da expressão das proteínas foi analisada por eletroforese em gel de poliacrilamida.

\subsection{Eletroforese em gel de poliacrilamida contendo SDS (SDS-PAGE)}

As separações eletroforéticas foram realizadas pelo método de Laemmli (Laemmli et al., 1970) em tampão de corrida Tris/glicina/SDS (Tris-HCl 25 mM, glicina 192 mM e SDS $0,1 \%, \mathrm{pH} 8,3)$, sob voltagem de $120 \mathrm{~V}$, à temperatura ambiente.

A acrilamida foi utilizada na concentração de 5\% no gel de empilhamento e de $12 \%$ no gel de separação, em espessura de $1 \mathrm{~mm}$. As amostras foram preparadas em tampão de amostra redutor 5x (Tris-HCl $50 \mathrm{mM} \mathrm{pH} \mathrm{6,8,} \mathrm{azul} \mathrm{de} \mathrm{bromofenol} 0,1 \%$, glicerol 10\%, $\beta$ mercaptoetanol $5 \%$, SDS $2 \%$ ) e aquecidas a $96^{\circ} \mathrm{C}$ por 3 min antes da aplicação em gel. Para acompanhar a corrida das amostras no gel foi aplicado padrão de massa molecular Pageruler (Fermentas).

A presença das bandas proteicas foi detectada pela imersão do gel em solução corante (azul Coomassie R250 0,25\%, ácido acético glacial 10\%, etanol 45\%) por 1 h sob agitação. O descoramento foi feito com solução descorante (ácido acético glacial 10\% e,etanol 30\%) até a visualização nítida das bandas de proteínas.

\subsection{Purificação das proteínas}

As proteínas expressas foram coletadas na fração insolúvel dos lisados bacterianos (corpúsculos de inclusão). Os precipitados bacterianos foram ressuspendidos em $30 \mathrm{ml}$ de PBS ( $\mathrm{NaCl} 1,37 \mathrm{M}, \mathrm{KCl}$ 0,027 M, $\mathrm{Na}_{2} \mathrm{HPO}_{4}$ 0,10 M, $\mathrm{KH}_{2} \mathrm{PO}_{4}$ 0,017 M, pH 7,4) contendo $5 \mathrm{mM}$ imidazol e submetidos à lise, utilizando-se sonicador por 30 ciclos de $30 \mathrm{seg}$, mantendo os precipitados no gelo. Após sonicação, os lisados foram centrifugados a 9,8 $g$ por 10 min a $4{ }^{\circ} \mathrm{C}$, o sobrenadante foi estocado a $-20^{\circ} \mathrm{C}$ e o sedimento contendo os corpúsculos de inclusão foi solubilizado com $25 \mathrm{~mL}$ de PBS contendo $8 \mathrm{M}$ de ureia. A purificação foi feita por cromatografia de afinidade a metal. Uma coluna de $5 \mathrm{ml}$ pré-empacotada $\operatorname{His}_{\text {Trap }}{ }^{T M} H P(G E$ Healthcare) foi previamente carregada com $\mathrm{Ni}_{2} \mathrm{SO}_{4} 300 \mathrm{mM}$. As proteínas recombinantes ligam-se ao níquel pelos resíduos de histidinas. O sobrenadante contendo os corpúsculos 
solubilizados em $8 \mathrm{M}$ de ureia foi diluído por gotejamento em $2 \mathrm{~L}$ de PBS contendo $5 \mathrm{mM}$ de imidazol e passados pela coluna. Para eliminação das proteínas contaminantes, a resina foi lavada com $50 \mathrm{ml}$ de PBS contendo $5 \mathrm{mM}$ de imidazol. As proteínas foram eluídas com PBS contendo concentrações crescentes de imidazol $(20 \mathrm{mM}$ até $1 \mathrm{M})$. As frações contendo a proteína purificada foram reunidas, concentradas por ultrafiltração no sistema de células de agitação Amicom (Merk Millipore) e dialisadas por 16 h contra PBS (pH 7,4).

As proteínas foram analisadas por eletroforese em gel de poliacrilamida $12 \% \mathrm{em}$ condições descritas no item 3.11. As massas moleculares das proteínas recombinantes foram calculadas a partir da composição de aminoácidos de cada proteína, utilizando-se o programa Gene Runner.

3.12 Determinação da concentração das proteínas purificadas

As proteínas Lig possuem poucos aminoácidos aromáticos o que dificulta a quantificação por métodos colorimétricos como o de Bradford (1976). A concentração total das proteínas foi determinada por densitometria óptica (Densitômetro 65-800, BioRad), usando o programa Quantity One.

3.13 Produção de antissoros policlonais contra proteínas recombinantes

Camundongos BALB/c fêmeas com 4 a 6 semanas de idade foram inoculadas por via intraperitoneal com doses de $250 \mu \mathrm{l}$ contendo $5 \mu \mathrm{g}$ de proteína recombinante (LigAC, LigBC ou LigBN) mais $50 \mu \mathrm{g}$ de hidróxido de alumínio utilizado como adjuvante. Dois reforços foram aplicados em um intervalo de 15 dias com a mesma preparação de proteína. Uma semana após a última inoculação, os camundongos foram anestesiados e a coleta de sangue foi feita pelo plexo retro-orbital através de capilares sem heparina. O uso de animais para experimentação foi aprovado pela Comissão de ética em experimentação Animal (CEEA) Protocolo resitrado sob $\mathrm{n}^{\circ} 99$ nas fls. 61 do livro 02 .

Antes da primeira inoculação foram coletadas amostras de soro (pré-imunes) dos animais para serem usadas como controle. Os soros imunes foram estocados a $-20{ }^{\circ} \mathrm{C}$ e analisados por Enzyme Linked Immunosorbent Assay (ELISA) para determinação dos títulos dos anticorpos específicos. 
3.14 Determinação do título de anticorpos específicos produzidos contra as proteínas recombinantes Lig

As proteínas recombinantes $\operatorname{LigAC}, \operatorname{LigBC}$ e $\operatorname{LigBN}(5 \mu \mathrm{g} / \mathrm{ml})$ diluídas em tampão PBS foram imobilizadas em placas de 96 poços (Costar 3590 High Binding, Corning Inc.) por $16 \mathrm{~h} \mathrm{a} 4{ }^{\circ} \mathrm{C}$. As placas foram lavadas 3 vezes com PBS-T (PBS-Tween $20(0,05 \%)$ entre cada etapa que se segue. Os sítios não específicos de ligação foram bloqueados com albumina de soro bovino (BSA) $1 \%$ por $2 \mathrm{~h}$ a $37^{\circ} \mathrm{C}$. Após bloqueio, os soros dos animais foram aplicados em diluições seriadas de 1:100 até 1:25600 em tampão PBS e incubados por $1 \mathrm{~h}$ a $37^{\circ} \mathrm{C}$. Após este período, as placas foram incubadas por $1 \mathrm{~h}$ a $37{ }^{\circ} \mathrm{C}$ com anti-IgG de camundongo conjugado com peroxidase (KPL) na diluição de 1:5000. A reação de revelação foi realizada com a solução (O-fenilenodiamina (OPD) $0,04 \%, \mathrm{H}_{2} \mathrm{O}_{2}$, 0,015\% em tampão citrato-fosfato $\mathrm{pH}$ $5,0)$ e interrompida com a adição de $50 \mu \mathrm{lde} \mathrm{H}_{2} \mathrm{SO}_{4} 4 \mathrm{~N}$. A leitura da absorbância foi feita a $492 \mathrm{~nm}$ em leitor de microplacas (Labsystems Uniscience, Multiskan EX). O título de anticorpos foi considerado como a diluição do soro capaz de resultar em leitura de absorbância igual a 0,1 a $492 \mathrm{~nm}$.

\subsection{Proteínas do sistema complemento e anticorpos}

Soros humanos (SHNs) obtidos de doadores saudáveis foram usados como fonte de FH, C4BP e plasminogênio. Aproximadamente $40 \mathrm{ml}$ de sangue foram colhidos de cada doador, em frascos de vidro sem anticoagulante. Após descolamento e descarte dos coágulos, o sangue foi centrifugado a $1125 \mathrm{~g}$ por $10 \mathrm{~min}$ a $4{ }^{\circ} \mathrm{C}$. Soros de pelo menos 20 doadores foram utilizados para constituir uma mistura de SHN. Aprovado pela Comissão de Ética Pesquisas com Seres Humanos-ICB/USP (PARECER 869/CEP). Os soros foram devidamente aliquotados e armazenados a $-80{ }^{\circ} \mathrm{C}$. As proteínas purificadas $\mathrm{FH}, \mathrm{C} 4 \mathrm{BP}, \mathrm{C} 2, \mathrm{C} 3, \mathrm{C} 4, \mathrm{C} 5$, C3b, C4b, FI foram adquiridas comercialmente da Complement Technology, Inc. Os anticorpos comerciais utilizados foram: anticorpo policlonal anti-C3, anti-C4, humano produzidos em cabra (Complement Technology, Inc), anticorpo policlonal anti-C4BP humano produzido em coelho (Calbiochem), anticorpo policlonal anti-FH humano produzido em coelho (Cedido por Dr. Pilar Sanchez, Hospital Universitário La Paz, Madrid, Espanha) ou produzido em cabra (Quidel), anti-MAC (neo C5b-9) humano produzido em coelho (Calbiochem), anti-IgG de cabra e coelho conjugado à peroxidase (KPL), plasminogênio, ativador de plasminogênio tipo uroquinase (uPA), inibidor do ativador de plasminogênio 
(PAI-1) e anti-plasminogênio feito em coelho foram adquiridos da Sigma-Aldrich. Anticorpo anti-plasminogênio humano capaz de reconhecer o domínio kringle 5 foi feito em cabra (BD Biosciences).

3.16 Análise da interação das proteínas recombinantes de Leptospira com FH e C4BP

A interação das proteínas recombinantes com os reguladores do complemento FH e C4BP foi analisada por Western blot com sobreposição e ELISA.

\subsubsection{Western blot com sobreposição}

Proteínas recombinantes de Leptospira foram submetidas à separação por SDS-PAGE 12\% em condições não redutoras com tampão de amostra 5x (Tris-HCl 50 mM pH 6,8, azul de bromofenol $0,1 \%$, glicerol $10 \%$, SDS $2 \%$ ) e transferidas para membranas de nitrocelulose. Sítios de ligação inespecíficos foram bloqueados com 10\% de leite desnatado em PBS-T por $18 \mathrm{~h} \mathrm{a} 4{ }^{\circ} \mathrm{C}$. Após três lavagens com PBS-T as membranas foram incubadas por $1 \mathrm{~h}$ e $30 \mathrm{~min}$ à temperatura ambiente com $10 \%$ de SHN como fonte de FH ou C4BP. Após cinco lavagens com PBS-T, as membranas foram incubadas por $60 \mathrm{~min}$ com anti-FH (Quidel) feito em cabra ou anti-C4BP (Calbiochem) feito em coelho e incubados com anti-IgG específico (KPL) conjugado à peroxidase nas diluições de 1:10000 por $1 \mathrm{~h}$ à temperatura ambiente. Após três lavagens com PBS-T, foi feita a revelação por quimioluminescência empregando o kit SuperSignal West Pico Chemiluminescent (Thermo Scientific).

\subsubsection{ELISA}

Proteínas recombinantes de Leptospira (10 $\mu \mathrm{g} / \mathrm{ml})$ (LigAC, LigBC, LigBN, LIC10301) diluídas em PBS foram imobilizadas em placas de 96 poços (Costar 3590 High Binding, Corning Inc.). Foram realizadas 3 lavagens com PBS-T entre cada etapa que se segue. Os sítios não específicos de ligação foram bloqueados usando BSA $3 \%$ por 2 h a 37 ${ }^{\circ} \mathrm{C}$. Após bloqueio, as proteínas foram incubadas com $(0-5 \mu \mathrm{g})$ de $\mathrm{FH}$ ou C4BP purificados (Complement Technology, Inc) por $1 \mathrm{~h}$ a $37^{\circ} \mathrm{C}$. Após lavagem, os poços foram incubados com anti-FH humano (1:10000) feito em cabra ou anti-C4BP humano (1:5000) feito em coelho diluídos em PBS-T $1 \%$ BSA por $1 \mathrm{~h}$ a $37{ }^{\circ} \mathrm{C}$. Após este período, o segundo anticorpo anti-IgG conjugado com peroxidase foi adicionado na diluição de 1:5000 em PBS-T 1\% BSA 
e incubado por $1 \mathrm{~h}$ a $37{ }^{\circ} \mathrm{C}$. A revelação foi feita com solução de revelação (OPD 0,04\%, $\mathrm{H}_{2} \mathrm{O}_{2}$ 0,015\% em tampão citrato-fosfato $\mathrm{pH} 5,0$ ) e interrompida com a adição de $50 \mu \mathrm{l}$ de $\mathrm{H}_{2} \mathrm{SO}_{4} 4 \mathrm{~N}$. A leitura da absorbância foi feita a $492 \mathrm{~nm}$ em leitor de microplacas (Labsystems Uniscience, Multiskan EX).

\subsection{Avaliação da atividade de co-fator de FH e C4BP}

$\mathrm{A}$ atividade de co-fator do $\mathrm{FH}$ ou $\mathrm{C} 4 \mathrm{BP}$ ligados às proteínas recombinantes de leptospira foi avaliada pela clivagem de $\mathrm{C} 3 \mathrm{~b}$ ou $\mathrm{C} 4 \mathrm{~b}$ pelo FI, respectivamente. As proteínas Ligs $(10 \mu \mathrm{g} / \mathrm{ml})$ diluídas em PBS foram imobilizadas em placas de 96 poços (Costar 3590 High Binding, Corning Inc.). Sítios não específicos de ligação foram bloqueados usando BSA $3 \%$. Após bloqueio, as proteínas foram incubadas por $1 \mathrm{~h}$ a $37^{\circ} \mathrm{C} \operatorname{com} 2 \mu \mathrm{g}$ de $\mathrm{FH}$ ou C4BP purificados prosseguindo-se com três lavagens com PBS. A seguir, foram incubadas por períodos de 1,2 e $4 \mathrm{~h}$ a $37{ }^{\circ} \mathrm{C}$ com $500 \mathrm{ng}$ de C3b ou C4b e $250 \mathrm{ng}$ de FI (Complement Technology, Inc) em PBS.

Após incubação, as amostras foram coletadas e analisadas por SDS-PAGE $12 \% \mathrm{em}$ condições redutoras com o objetivo de observar a clivagem de C3b ou C4b. As proteínas foram transferidas para membrana de nitrocelulose e sítios não específicos de ligação foram bloqueados usando $10 \%$ de leite desnatado em PBS-T por $18 \mathrm{~h}$ a $4{ }^{\circ} \mathrm{C}$. Em seguida, as membranas foram lavadas três vezes com PBS-T e incubadas com anticorpos específicos. Os fragmentos gerados após clivagem pelo FI foram detectados usando-se anticorpo policlonal anti-C3 humano (Complement Technology, Inc) na diluição 1:10000 ou anticorpo monoclonal anti-C4d humano (Quidel) na diluição 1:1000. Subsequentemente, as membranas foram lavadas com PBS-T e incubadas por 60 min à temperatura ambiente com anti-IgG de cabra na diluição 1:10000 (KPL) e anti-IgG de camundongo na diluição de 1:5000 (KPL) conjugados com peroxidase. Ambos os anticorpos foram detectados por quimioluminescência empregando o kit SuperSignal West Pico Chemiluminescent (Thermo Scientific).

\subsection{Ensaio de competição entre FH e C4BP}

Este ensaio foi feito com o objetivo de verificarmos se FH e C4BP competeriam pelo mesmo sítio de ligação presente nas proteínas Lig. As proteínas LigAC, LigBC e LigBN (10 $\mu \mathrm{g} / \mathrm{ml}$ ) diluídas em PBS foram imobilizadas em placas de 96 poços (Costar 3590 High Binding, Corning Inc.) por $16 \mathrm{~h} \mathrm{a} 4{ }^{\circ} \mathrm{C}$. As placas foram lavadas 3 vezes com PBS-T entre 
cada etapa. Os sítios não específicos de ligação foram bloqueados usando BSA $1 \%$ por $2 \mathrm{~h}$ a $37{ }^{\circ} \mathrm{C}$. Após bloqueio, as proteínas foram incubadas ao mesmo tempo com uma concentração fixa de FH $(1 \mu \mathrm{g})$ em PBS e com concentrações crescentes de C4BP $(0 ; 0,25 ; 0,5 ; 1 ; 2 ; 4 \mu \mathrm{g})$ por $1 \mathrm{~h}$ a $37{ }^{\circ} \mathrm{C}$. O ensaio foi realizado em duplicata de tal forma que as placas pudessem ser incubadas com anti-FH (1:5000) (Hospital Universitário La Paz) e anti-C4BP (1:5000) (Calbiochem) por $1 \mathrm{~h}$ a $37{ }^{\circ} \mathrm{C}$. Após este período, o segundo anticorpo anti-IgG de coelho (Sigma-Aldrich) conjugado com peroxidase foi adicionado na diluição de 1: 5000 e incubado por $1 \mathrm{~h}$ a $37{ }^{\circ} \mathrm{C}$. A revelação foi feita com solução de revelação (OPD 0,04\%, $\mathrm{H}_{2} \mathrm{O}_{2}, 0,015 \%$ em tampão citrato-fosfato $\mathrm{pH}$ 5,0) e interrompida com a adição de $50 \mu \mathrm{l}$ de $\mathrm{H}_{2} \mathrm{SO}_{4} 4 \mathrm{~N}$. A leitura da absorbância foi feita a $492 \mathrm{~nm}$ em leitor de microplacas (Labsystems Uniscience, Multiskan EX).

3.19 Sorovares de Leptospira e condições de cultivo

A cepa patogênica L. interrogans sorovar Kennewicki, estirpe Pomona Fromm (LPF) e não patogênica L. biflexa estirpe Patoc foram fornecidas pelo Prof. Dr. Sílvio Arruda Vasconcellos (Faculdade de Medicina Veterinária e Zootecnia - USP). As cepas L. biflexa estirpe Patoc transgênicas para LigA ou LigB (Figueira et al., 2011) foram fornecidas pelo Dr. Claúdio Pereira Figueira da Fundação Oswaldo Cruz, Salvador, Brazil e o Dr. Albert Ko da Universidade de Yale, Estados Unidos. Todas as bactérias foram cultivadas a $29{ }^{\circ} \mathrm{C}$ por 5 dias, sob condições aeróbicas em meio líquido EMJH (Difco- EUA) suplementado com Leptospira enrichment EMJH (BD-EUA). As leptospiras transgênicas foram selecionadas acrescentando-se ao meio espectinomicina no volume final de $50 \mu \mathrm{g} / \mathrm{ml}$.

3.20 Avaliação do efeito protetor do FH na sobrevivência da L. interrogans

Culturas de L. interrogans sorovar Kennewicki, estirpe Pomona Fromm (LPF) foram centrifugadas a $2800 \mathrm{~g}$ por $20 \mathrm{~min}$ a $21^{\circ} \mathrm{C}$. Os precipitados foram lavados 2 vezes com PBS e ressuspendidos no volume final de $2 \mathrm{ml}$. Em seguida, as bactérias foram contadas utilizandose microscópio de campo escuro. 3 x $10^{8}$ bactérias bactérias foram incubadas no volume final de $100 \mu$ por $2 \mathrm{~h}$ a $37{ }^{\circ} \mathrm{C}$ sob agitação com $40 \%$ de soro humano não imune depletado de $\mathrm{FH}$ (SHD-FH), ou com SHD-FH suplementado com quantidades crescentes de FH purificado (50$500 \mu \mathrm{g}$ ). Após incubação, a sobrevivência das leptospiras em cada tratamento foi analisada pela contagem do número de bactérias viáveis empregando microscopia de campo escuro em 
uma câmara de Petroff-Hausser. Ao contrario de leptospiras vivas, as leptospiras mortas não são visivelmente observadas por microscopia de campo escuro devido a que quando morrem se fragmentam de maneira que perden sua morfologia típica, tornando-se indistinguíveis. Este experimento foi repetido três vezes e análises estatísticas foram feitas empregando-se o teste $t$ de Student. Para efeitos comparativos, $500 \mu \mathrm{g}$ de $\mathrm{FH}$ purificado (concentração fisiológica) foram considerados como representativos de $100 \%$ da sobrevivência. A concentração sérica de FH varia de 242 a $759 \mu \mathrm{g} / \mathrm{ml}$ em indivíduos adultos saudáveis (Ferreira de Paula et al., 2003).

3.21 Avaliação da interação da espécie patogênica L. interrogans sorovar Kennewicki, estirpe Pomona Fromm com FH, FHL-1 e FHR-1 $\alpha / \beta$

Culturas de LPF foram centrifugadas a $2800 \mathrm{~g}$ por $20 \mathrm{~min}$ a $21{ }^{\circ} \mathrm{C}$. Os precipitados foram lavados 2 vezes com PBS e ressuspendidos no volume final de $2 \mathrm{ml}$. Em seguida, as bactérias foram contadas utilizando-se microscópio de campo escuro. Um total de $1 \times 10^{9}$ bactérias foi incubado com FH purificado (Complement Technology, Inc), FHL-1 e FHR-1 (recombinantes cedidas pelo Dr. Mihaly Józsi, pesquisador do Leibniz Institute for Natural Product Research and Infection Biology-Hans Knöll Institute, Jena, Alemanha) ( $2 \mu$ g cada) no volume final de $100 \mu \mathrm{l}$ por $1 \mathrm{~h}$ a $37^{\circ} \mathrm{C}$ sob agitação. Após cinco lavagens com PBS (o sobrenadante da quinta lavagem foi coletado), os precipitados foram submetidos a SDSPAGE $12 \%$ sob condições não redutoras e transferidos para membranas de nitrocelulose. Sítios de ligação inespecífica foram bloqueados com PBS-T, contendo 10\% de leite desnatado por $18 \mathrm{~h} \mathrm{a} 4^{\circ} \mathrm{C}$. Após três lavagens com PBS-T as membranas foram incubadas por $1 \mathrm{~h}$ com o anticorpo policlonal anti-FH (Quidel) feito em cabra e seguidamente incubadas com anti-IgG de cabra conjugado com peroxidase (Sigma-Aldrich) por $1 \mathrm{~h}$ à temperatura ambiente sob agitação. Após três lavagens com PBS-T, a revelação foi feita por quimioluminescência SuperSignal West Pico Chemiluminescent (Thermo Scientific).

3.22 Avaliação da interação das proteínas Lig com FHL-1, FHR-1, e os domínios SCRs 814 e SCRs 15-20 recombinantes por ELISA

As proteínas recombinantes LigAC, LigBC e LigBN $(10 \mu \mathrm{g} / \mathrm{ml})$ diluídas em PBS foram imobilizadas em placas de 96 poços (Costar 3590 High Binding, Corning Inc.). Estas foram lavadas 3 vezes com PBS-T entre cada etapa. Os sítios não específicos de ligação 
foram bloqueados usando BSA $1 \%$ por $2 \mathrm{~h}$ a $37{ }^{\circ} \mathrm{C}$. Após bloqueio, as proteínas foram incubadas por $1 \mathrm{~h}$ a $37^{\circ} \mathrm{C}$ com 0,5 $\mu \mathrm{g}$ de FH (Complement Technology, Inc), FHL-1, FHR-1, ou com os fragmentos SCRs 8-14 e SCRs 15-20, cedidos pelo Dr. Mihály Jószi. Após lavagens, as placas foram incubadas com anti-FH (Quidel) na diluição de 1:10000 por $1 \mathrm{~h} \mathrm{a}$ $37{ }^{\circ} \mathrm{C}$. Após este período, anticorpo anti-IgG de cabra conjugado com peroxidase (KPL) foi adicionado na diluição de 1:10000 e incubado por $1 \mathrm{~h}$ a $37^{\circ} \mathrm{C}$. A revelação foi feita com solução de revelação (OPD $0,04 \%, \mathrm{H}_{2} \mathrm{O}_{2} \quad 0,015 \%$ em tampão citrato-fosfato $\mathrm{pH} 5,0$ ) e

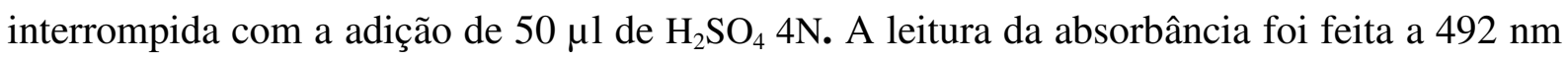
em leitor de microplacas (Labsystems Uniscience, Multiskan EX).

3.23 Avaliação da inibição da ligação de FH com a proteína LigBC utilizando anticorpos monoclonais contra diferentes SCRs

A proteína LigBC $(10 \mu \mathrm{g} / \mathrm{ml})$ diluídas em PBS foram imobilizadas em placas de 96 poços (Costar 3590 High Binding, Corning Inc.). Os sítios não específicos de ligação foram bloqueados usando BSA $1 \%$ por $2 \mathrm{~h}$ a $37^{\circ} \mathrm{C}$. Após este período, a proteína foi incubada por 1 $\mathrm{h}$ a $37{ }^{\circ} \mathrm{C}$ com $\mathrm{FH}$ (previamente incubado por $15 \mathrm{~min}$ com $0,1 \mu \mathrm{g} / \mathrm{ml}$ de anticorpos monoclonais específicos para os SCR 1-4 (anti-1-4), SCR5 (OX24x), SCRs 8-14 (131x), SCR 20 (C18), SCR 20 (A229) cedidos pelo Dr. Mihaly Jószi. Após lavagens, a placa foi incubada com anti-FH policlonal (Quidel) feito em cabra por $1 \mathrm{~h}$ a $37^{\circ} \mathrm{C}$. Após este período, anticorpo anti-IgG de cabra conjugado com peroxidase (Sigma-Aldrich) foi adicionado na diluição de 1:10000 e incubado por $1 \mathrm{~h}$ a $37^{\circ} \mathrm{C}$. A revelação foi feita com solução de revelação (OPD $0,04 \%, \mathrm{H}_{2} \mathrm{O}_{2}$ 0,015\% em tampão citrato-fosfato $\left.\mathrm{pH} 5,0\right)$ e interrompida com a adição de $50 \mu 1$ de $\mathrm{H}_{2} \mathrm{SO}_{4}$ 4N. A leitura da absorbância foi feita a $492 \mathrm{~nm}$ em leitor de microplacas (Labsystems Uniscience, Multiskan EX).

3.24 Avaliação por Western blot da interação de leptospiras transgênicas para LigA e LigB com FH e C4BP

Culturas de L. interrogans sorovar Kennewicki, estirpe Pomona Fromm (LPF), Leptospira biflexa sorovar Patoc, Leptospira biflexa estirpe Patoc transgênica para LigA ou LigB foram centrifugadas a $2800 \mathrm{~g}$ por $20 \mathrm{~min}$ a $21{ }^{\circ} \mathrm{C}$. Os precipitados foram lavados uma vez com PBS e ressuspendidos no volume final de $1 \mathrm{ml}$. Em seguida, as bactérias foram contadas utilizando-se microscópio de campo escuro. Um total de 1 x $10^{8}$ bactérias de cada 
sorovar foi incubado com $10 \%$ de SHN por $1 \mathrm{~h}$ a $37{ }^{\circ} \mathrm{C}$ sob agitação. Após cinco lavagens com PBS-T (o sobrenadante da quinta lavagem foi coletado), os precipitados foram submetidos a SDS-PAGE $12 \%$ e transferidos para membranas de nitrocelulose. Sítios de ligação inespecífica foram bloqueados com PBS-T, contendo $10 \%$ de leite desnatado por $18 \mathrm{~h}$ a $4{ }^{\circ} \mathrm{C}$. Após três lavagens com PBS-T as membranas foram incubadas por $1 \mathrm{~h}$ com os anticorpos policlonais anti-FH (Quidel) feito em cabra ou anti-C4BP (Calbiochem) feito em coelho e seguidamente incubadas com anti-IgG de cabra ou coelho conjugado com peroxidase (KPL) por $1 \mathrm{~h}$ à temperatura ambiente sob agitação. Após três lavagens com PBS-T, a revelação foi feita por quimioluminescência SuperSignal West Pico Chemiluminescent (ECL)(Thermo Scientific).

3.25 Avaliação da sobrevivência de leptospiras transgênicas para LigA e LigB na presença de soro humano normal

Culturas de L. interrogans sorovar Kennewicki, estirpe Pomona Fromm (LPF), Leptospira biflexa sorovar Patoc, Leptospira biflexa estirpe Patoc transgênica para LigA ou LigB foram centrifugadas a $2800 \mathrm{~g}$ por $20 \mathrm{~min}$ a $21{ }^{\circ} \mathrm{C}$. Os precipitados foram lavados uma vez com PBS e ressuspendidos no volume final de $1 \mathrm{ml}$. Em seguida, as bactérias foram contadas utilizando-se microscópio de campo escuro. Suspensões contendo 5 x $10^{8}$ bactérias de cada sorovar foram incubadas com 20,40 e $60 \%$ de soro humano normal ou com $60 \%$ de soro humano inativado por $2 \mathrm{~h}$ a $37^{\circ} \mathrm{C}$. Após incubação, a sobrevivência das leptospiras em cada tratamento foi analisada pela contagem do número de bactérias viáveis empregando microscopia de campo escuro em uma câmara de Petroff-Hausser.

Este experimento foi repetido três vezes e o tratamento com SHN inativado foi considerado como grupo representativo de $100 \%$ da sobrevivência.

3.26 Avaliação da atividade de co-fator de FH e C4BP ligados na L. biflexa transgênica para LigA ou LigB

$\mathrm{A}$ atividade de co-fator do $\mathrm{FH}$ ou $\mathrm{C} 4 \mathrm{BP}$ ligados às diferentes bactérias (L. biflexa sorovar Patoc transgênica para LigA e L. biflexa sorovar Patoc transgênica para LigB) foi avaliada pela clivagem de $\mathrm{C} 3 \mathrm{~b}$ ou $\mathrm{C} 4 \mathrm{~b}$ pelo $\mathrm{FI}$, respectivamente. As bactérias foram centrifugadas a $2800 \mathrm{~g}$ por $20 \mathrm{~min}$ a $21^{\circ} \mathrm{C}$. Os precipitados foram lavados uma vez com PBS e ressuspendidos no volume final de $1 \mathrm{ml}$. Em seguida, as bactérias foram contadas 
empregando-se microscopia de campo escuro. 2 × $10^{8}$ bactérias foram incubadas por $1 \mathrm{~h}$ a 37 ${ }^{\circ} \mathrm{C}$ com $5 \%$ de SHN ou $2 \mu \mathrm{g}$ de $\mathrm{FH}$ ou C4BP purificados. Após lavagens, foram adicionados 500 ng de C3b ou C4b e 250 ng de FI (Complement Technology, Inc) em PBS. Estas reações foram incubadas por períodos de 1,2 e $4 \mathrm{~h}$ a $37^{\circ} \mathrm{C}$.

Após incubação, as amostras foram coletadas e analisadas por SDS-PAGE $12 \% \mathrm{em}$ condições redutoras com o objetivo de observar a clivagem de C3b ou C4b. As proteínas foram transferidas para membrana de nitrocelulose e sítios não específicos de ligação foram bloqueados usando $10 \%$ de leite desnatado em PBS-T por $18 \mathrm{~h}$ a $4{ }^{\circ} \mathrm{C}$. Em seguida, as membranas foram lavadas três vezes com PBS-T e incubadas com anticorpos específicos. Os fragmentos gerados após clivagem pelo FI foram detectados usando-se os anticorpos policlonais anti-C3 ou anti-C4 humanos feitos em cabra (Complement Technology, Inc) na diluição 1:5000. Subsequentemente, as membranas foram lavadas com PBS-T e incubadas por 60 min à temperatura ambiente com anti-IgG de cabra conjugado com peroxidase (KPL) na diluição 1:10000. Ambos os anticorpos foram detectados por quimioluminescência empregando o kit SuperSignal West Pico Chemiluminescent (Thermo Scientific).

3.27 Análise por citometria de fluxo da deposição de C3, C4 e MAC em leptospiras

Culturas de $2 \times 10^{8}$ bactérias de L. interrogans sorovar Kennewicki, estirpe Pomona Fromm (LPF), L. biflexa (Patoc wt), L. biflexa sorovar Patoc transgênica para LigA (Patoc LigA) e L. biflexa sorovar Patoc transgênica para LigB (Patoc LigB) foram incubadas por 1h com 10\% de SHN ou com PBS (controle negativo) no volume final de $100 \mu$ l. Após incubação, as bactérias foram centrifugadas e o precipitado foi ressuspendido em $40 \mu \mathrm{l}$ de anti-C3, anti-C4 ou anti-MAC humano, na diluição de 1:100 em PBS 1\% BSA. Após lavagem, as bactérias foram incubadas por mais $30 \mathrm{~min}$ com anti-IgG de cabra conjugado com isotiocianato de fluoresceína (FITC) (BD Biosciences) ou anti-IgG de coelho conjugado com ficoeritrina (PE) (BD Biosciences) na diluição de 1:200 em PBS contendo 1\% BSA. Após várias lavagens, as bactérias foram ressuspendidas em PBS no volume final de $300 \mu \mathrm{l}$ para análise por citometria de fluxo no FACSCanto II (BD Biosciences), Software FlowJo. Todas as marcações foram realizadas no mesmo dia. Os histogramas em sobreposição representam a detecção da fluorescência emitida pelo fluorocromo FITC ou PE. No grupo controle as bactérias foram incubadas apenas com os anticorpos primário (anti-C3, anti-C4 humanos feitos em cabra e anti-MAC humano feitos em coelho) e secundário (anti - IgG de cabra conjugado com FITC e anti-IgG de coelho conjugado com FITC ou PE) para detectarmos a 
fluorescência emitida pela ligação inespecífica destes anticorpos diretamente com a bactéria, na ausência de SHN. A interação das bactérias com as proteínas do complemento foi analisada com as bactérias previamente incubadas com SHN e, posteriormente, incubadas com os anticorpos primário e secundário.

3.28 Análise da interação de plasminogênio com as proteínas recombinantes de Leptospira

A interação de plasminogênio com as proteínas recombinantes de Leptospira foi analisada por ELISA e Western blot com sobreposição.

\subsubsection{ELISA}

As placas foram sensibilizadas com $10 \mu \mathrm{g} / \mathrm{ml}$ de plasminogênio diluído em PBS no volume final de $100 \mu \mathrm{l}$ incubadas por $18 \mathrm{~h}$ a $4{ }^{\circ} \mathrm{C}$ (Costar 3590 High Binding, Corning Inc.). Entre cada etapa foram feitas 3 lavagens com PBS-T (PBS contendo 0,05\% de Tween 20). Os sítios não específicos de ligação foram bloqueados usando BSA $3 \%$ por 2 h a $37{ }^{\circ} \mathrm{C}$. Em seguida, as placas foram incubadas com concentrações de 0-0,5 $\mu \mathrm{g}$ das proteínas recombinantes de L. interrogans LigAC, LigBC, LigBN, LipL32, LIC10301 por $1 \mathrm{~h}$ a $37^{\circ} \mathrm{C}$. Após lavagens, as placas foram incubadas por $1 \mathrm{~h}$ a $37^{\circ} \mathrm{C}$ com os antissoros específicos na diluição de 1:10000 (feitos em camundongos, produzidos no nosso laboratório ou no Instituto Butantan pela pesquisadora Dra. Patrícia Abreu). Após este período de incubação, anti-IgG de camundongo conjugado com peroxidase (Sigma-Aldrich) foi adicionado às placas na diluição de 1:5000, incubando-as por $1 \mathrm{~h}$ a $37{ }^{\circ} \mathrm{C}$. A revelação foi feita com solução de revelação (OPD 0,04\%, $\mathrm{H}_{2} \mathrm{O}_{2}$ 0,015\% em tampão citrato-fosfato $\mathrm{pH} 5,0$ ) e interrompida com a adição de $50 \mu \mathrm{l}$ de $\mathrm{H}_{2} \mathrm{SO}_{4} 4 \mathrm{~N}$. A leitura da absorbância foi feita a $492 \mathrm{~nm}$ em leitor de microplacas (Labsystems Uniscience, Multiskan EX).

Para determinar se a interação das proteínas Ligs com plasminogênio era dependente de forças iônicas o resíduos de lisina, utilizamos o mesmo protocolo acima descrito, porém incubando com $1 \mu \mathrm{g}$ de plasminogênio na presença de diferentes concentrações de $\mathrm{NaCl}$ (50 mM, 100 mM, 200 mM e 400 mM) ou Acido aminocapróico (ACA, Sigma-Aldrich) (0,5 $\mathrm{mM}, 1,5 \mathrm{mM}$ e $10 \mathrm{mM})$. A interação entre plasminogênio e as proteínas Ligs nestas condições também foi detectada pelo protocolo de ELISA descrito anteriormente. 


\subsubsection{Western blot com sobreposição}

Proteínas recombinantes de L. interrogans (LigAC, LigBC, LigBN, LipL32, LIC10301) foram separadas por SDS-PAGE 12\% em condições não redutoras e transferidas para membranas de nitrocelulose. Sítios de ligação inespecíficos foram bloqueados com $10 \%$ de BSA em PBS-T por $16 \mathrm{~h}$ a $4{ }^{\circ} \mathrm{C}$. Após três lavagens com PBS-T as membranas foram incubadas por $1 \mathrm{~h}$ e $30 \mathrm{~min}$ à temperatura ambiente com $10 \mu \mathrm{g} / \mathrm{ml}$ de plasminogênio purificado. Após três lavagens com PBS-T, as membranas foram incubadas por $1 \mathrm{~h}$ com antiplasminogênio policlonal feito em coelho na diluição 1:500. Em seguida, as membranas foram novamente lavadas e incubadas por $1 \mathrm{~h}$ à temperatura ambiente com anti-IgG de coelho conjugado à peroxidase (KPL) na diluição de 1:5000. Após três lavagens com PBS-T, as membranas foram reveladas por quimioluminescência SuperSignal West Pico Chemiluminescent (Thermo Scientific).

3.29 Avaliação da capacidade do plasminogênio ligado às proteínas recombinantes de Leptospira de gerar plasmina

As proteínas recombinantes de L. interrogans (LigAC, LigBC, LigBN, LipL32, LIC10301) e BSA $(10 \mu \mathrm{g} / \mathrm{ml})$ diluídas em PBS foram imobilizadas em placas de 96 poços (Costar 3590 High Binding, Corning Inc.) e incubadas por $18 \mathrm{~h}$ a $4{ }^{\circ} \mathrm{C}$. Entre cada etapa foram feitas 3 lavagens com PBS-T. Os sítios não específicos de ligação foram bloqueados usando BSA $3 \%$ por $2 \mathrm{~h}$ a $37{ }^{\circ} \mathrm{C}$. Após bloqueio, as placas foram incubadas com plasminogênio purificado ( $2 \mu \mathrm{g} /$ poço), em seguida foram adicionadas $3 \mathrm{U}$ de uPA e o substrato específico para plasmina (dicloridrato de D-Val-Leu-Lys p-nitroanilida, SigmaAldrich) $(25 \mu \mathrm{g}$ por poço), no volume final de $100 \mu$ l. Incubação com plasminogênio + uPA+ inibidor 1 do ativador de plasminogênio (PAI-1) foi usada como controle negativo. As leituras da absorbância foram feitas a $405 \mathrm{~nm}$ em diferentes tempos (1-16 h).

3.30 Avaliação da atividade do plasminogênio ligado às proteínas recombinantes de L. interrogans sobre as proteínas do complemento

As proteínas recombinantes de L. interrogans (LigAC, LigBC, LigBN, LipL32, LIC10301) $(10 \mu \mathrm{g} / \mathrm{ml})$ diluídas em PBS foram imobilizadas em placas de 96 poços (Costar 3590 High Binding, Corning Inc.) e incubadas por 18 h a $4{ }^{\circ} \mathrm{C}$. Os sítios não específicos de 
ligação foram bloqueados usando BSA $3 \%$ por $2 \mathrm{~h}$ a $37{ }^{\circ} \mathrm{C}$. Após bloqueio, as placas foram incubadas com plasminogênio purificado $(2 \mu \mathrm{g})$, no volume final de $100 \mu \mathrm{l}$ por $1 \mathrm{~h}$ a $37{ }^{\circ} \mathrm{C}$. Após lavagens com PBS-T, foram adicionados $3 \mathrm{U}$ de uPA e $0,5 \mu \mathrm{g}$ das proteínas do complemento C3b ou C5 ou fibrinogênio depletado de plasminogênio no volume final de 50 $\mu$, com o objetivo de avaliar a capacidade da plasmina gerada de clivar proteínas do complemento ou fibrinogênio. Os produtos de clivagem foram coletados em diferentes tempos (1, 4 e 16 h), submetidos à SDS-PAGE 12\% sob condições redutoras sendo depois transferidos para membranas de nitrocelulose. Sítios de ligação inespecíficos foram bloqueados com PBS-T contendo $10 \%$ de leite desnatado por $16 \mathrm{~h} \mathrm{a} 4{ }^{\circ} \mathrm{C}$. Após três lavagens com PBS-T as membranas foram incubadas por $1 \mathrm{~h}$ com anti-C3/C5 policlonal (Complement Technology, Inc) feitos em cabra na diluição de 1:5000 ou anti- fibrinogênio feito em coelho na diluição de 1:3000 e seguidamente incubadas com anti-IgG de cabra conjugado com peroxidase (1:10000) ou anti-IgG de coelho conjugado com peroxidase (1:5000) por $1 \mathrm{~h}$ à temperatura ambiente sob agitação. Após três lavagens com PBS-T foi feita a revelação por quimioluminescência SuperSignal West Pico Chemiluminescent (Thermo Scientific).

3.31 Avaliação da participação de proteínas do sistema complemento na ativação de polimorfonucleares por leptospiras previamente opsonizadas

Com o objetivo de determinar se a interação de polimorfonucleares com $\mathrm{FH}$ dependeria de CR3 para a adesão e consequente ativação de PMNs na ausência de anticorpos específicos, experimentos de análises da explosão respiratória foram realizados.

Culturas de L. interrogans sorovar Kennewicki, estirpe Pomona Fromm e L. biflexa sorovar Patoc foram centrifugadas a $2800 \mathrm{~g}$ por $20 \mathrm{~min}$ a $21{ }^{\circ} \mathrm{C}$. Os precipitados foram lavados 2 vezes com PBS e ressuspendidos no volume final de $1 \mathrm{ml}$. Em seguida, as bactérias foram contadas por microscopia de campo escuro em câmara de Petroff-Hausser. Suspensões contendo $5 \times 10^{7}$ e $1 \times 10^{8}$ bactérias $/ \mathrm{ml}$ foram incubadas por $60 \mathrm{~min}$ a $37^{\circ} \mathrm{C}$ com $20 \%$ de SHN ou soro humano inativado a $56{ }^{\circ} \mathrm{C}$, SHN contendo EDTA $(100 \mathrm{mM})$ ou $2 \mu \mathrm{g}$ de FH, FI,C3b, $\mathrm{iC} 3 \mathrm{~b}, \mathrm{FH}+\mathrm{C} 3 \mathrm{~b}+\mathrm{FI}, \mathrm{FH}+\mathrm{C} 3 \mathrm{~b}, \mathrm{FH}+\mathrm{FI}, \mathrm{C} 3 \mathrm{~b}+\mathrm{FI}$ ou $20 \%$ de soro humano depletado de $\mathrm{FH}, \mathrm{C} 5$ ou C3.

Alíquotas de $150 \mu \mathrm{l}$ de sangue periférico foram incubadas com $2 \mathrm{ml}$ de tampão RBC lise (Quiagen) homogeneizadas no vortex e incubadas a $37^{\circ} \mathrm{C}$ por $10 \mathrm{~min}$. Após incubação e lise de eritrócitos, as preparações foram centrifugadas a $583 \mathrm{~g}$ por $10 \mathrm{~min}$ e o sobrenadante foi descartado. Em seguida foram adicionados $100 \mu \mathrm{l}$ de PBS e os respectivos ativadores 
(SHN, SHN inativado, SHN+ EDTA 100mM, SHD-C3, SHD-C5, SHD-FH,C3b, iC3b,FH, $\mathrm{FI}, \mathrm{FH}+\mathrm{C} 3 \mathrm{~b}+\mathrm{FI}, \mathrm{FH}+\mathrm{C} 3 \mathrm{~b}, \mathrm{FH}+\mathrm{FI}$ e BSA). Controles: Controle positivo: Células PMN estimulados com PMA (90 nM), marcados com DHR. Controle negativo: Células PMN sem estimulo, marcados com DHR. Controle basal: Células PMN sem estímulo, sem marcação com DHR.

Após $30 \mathrm{~min}$ de incubação com os ativadores, foram adicionados $4 \mu \mathrm{l}$ de dihidrorodamina-123 (Invitrogen) a todos os tubos exceto no controle não marcado. Os tubos foram incubados a $37{ }^{\circ} \mathrm{C}$ por $10 \mathrm{~min}$. Em seguida as células foram lavadas com $500 \mu \mathrm{de}$ PBS a $583 \mathrm{~g}$ por $10 \mathrm{~min}$. O sobrenadante foi descartado e as células foram ressuspendidas em $300 \mu \mathrm{l}$ de PBS. A suspensão celular foi imediatamente analisada por citometria de fluxo FACSCalibur (BD Biosciences), Software FlowJo. 


\section{RESULTADOS}

4.1 Seleção de proteínas recombinantes de Leptospira interrogans sorovar Copenhageni

A predição da localização celular das proteínas descritas na Tabela 1 foi feita pelo programa PSORT (Nakai, Kanehisa, 1991). Todas as proteínas selecionadas possuem um peptídeo sinal que direciona seu transporte do retículo endoplasmático para a membrana externa. Algumas delas são secretadas. Dentre as classes selecionadas, incluímos lipoproteínas, hemolisinas e proteínas de superfície com domínios Ig-like.

\subsection{Clonagem dos fragmentos gênicos no vetor pGEM-T Easy}

Fragmentos dos genes LIC10465 e LIC10464 correspondentes à porção C-terminal das proteínas LigA ( $\operatorname{LigAC})$ e $\operatorname{LigB}(\operatorname{LigBC})$ respectivamente, e à porção N-terminal conservada presente nas duas proteínas (LigBN) (Figura 14) foram amplificados por PCR e analisados após eletroforese em géis de agarose 1\% (Figura 15). Os fragmentos purificados foram clonados no vetor pGEM-T easy e a presença dos insertos foi confirmada após digestão com a enzima BamHI (LigAC) e XhoI (LigBC e LigBN). Os plasmídeos linearizados com essas enzimas apresentaram tamanhos compatíveis com os esperados (Figura 16). Todas as construções foram sequenciadas com iniciadores internos próprios às sequências do inserto e com os iniciadores M13F e M13R para verificar a eventual presença de mutações. Os clones sem alterações foram selecionados para as etapas subsequentes.

Figura 14 - Representação esquemática das proteínas Ligs

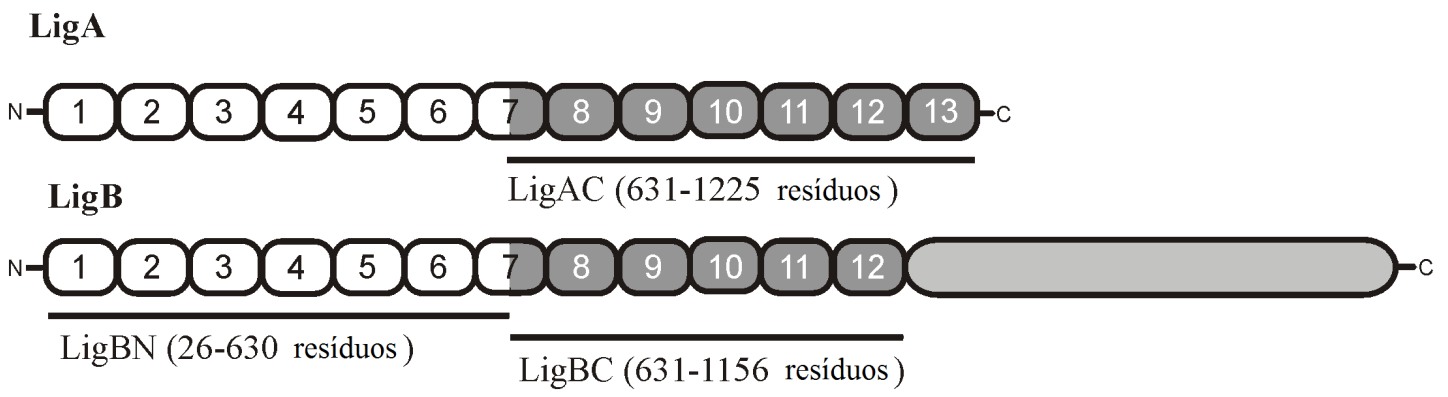

LigA e LigB possuem 13 e 12 domínios Big repetitivos de aproximadamente 90 aminoácidos. Essas proteínas apresentam $100 \%$ de identidade nos domínios repetitivos de suas porções N-terminais (LigBN). No entanto, os domínios repetitivos das porções C-terminais apresentam grande diversidade (fragmentos LigAC e LigBC). LigB ainda possui um longo domínio C-terminal não repetitivo que está ausente em LigA (Palaniappan et al., 2002, Matsunaga et al., 2003). As linhas representam as formas recombinantes utilizadas neste estudo. 
Figura 15 - Amplificação dos fragmentos gênicos por PCR

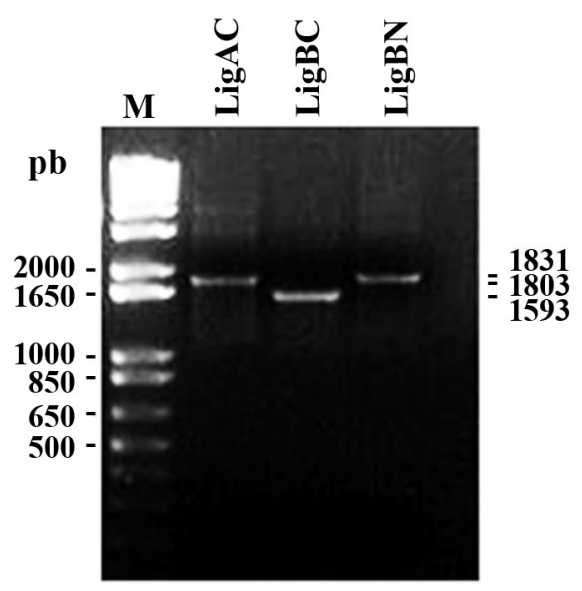

Fragmentos LIC10465 (LigAC, 1803 pb), LIC10464 (LigBC, 1593pb) e LigBN (1831 pb) foram amplificados por PCR a partir de DNA genômico de L. interrogans Copenhageni. M - marcador de tamanho em pares de bases (pb) (1 kb plus DNA ladder, Invitrogen).

Figura 16 - Análise dos plasmídeos pGEM-T contendo os insertos LigAC, LigBC ou LigBN
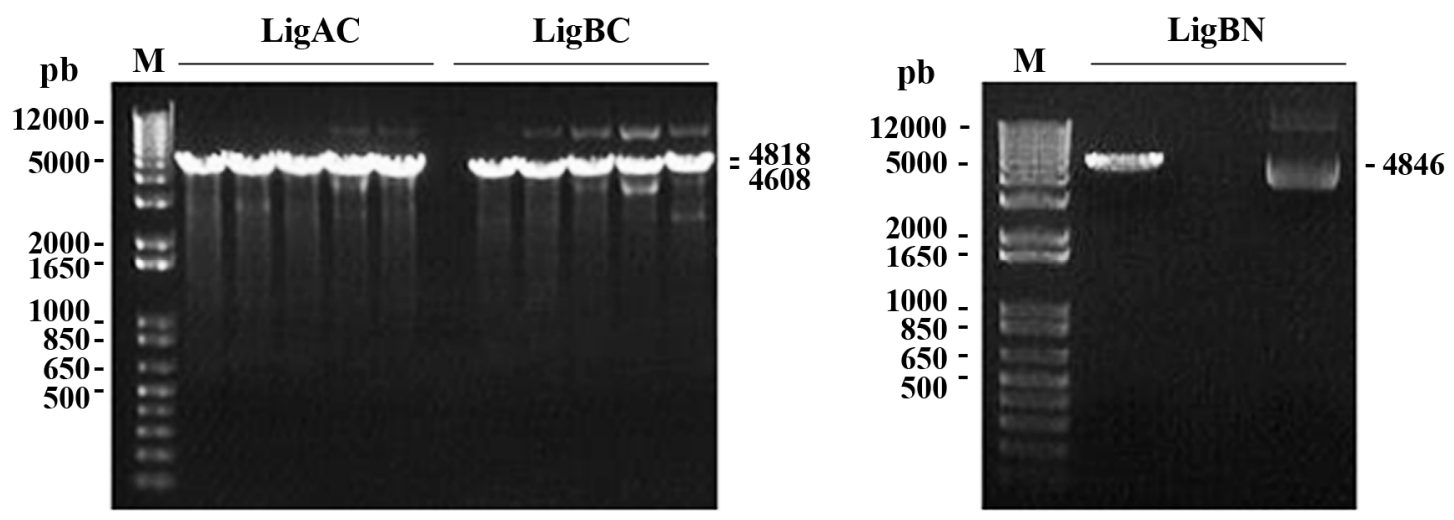

Plasmídeos pGEM-T contendo insertos LigAC (tamanho total: 4818 pb), LigBC (tamanho total: 4608 pb) e LigBN (tamanho total: $4846 \mathrm{pb}$ ) foram submetidos a tratamento com enzimas de restrição BamHI (LigAC) e XhoI (LigBC e $\mathrm{LigBN}) . \mathrm{M}$ - marcador de tamanho em pares de base (pb) (1 kb plus DNA ladder, Invitrogen).

4.3 Subclonagem dos fragmentos gênicos no vetor de expressão pAE

Os plasmídeos selecionados foram digeridos com as enzimas de restrição BamHI e NcoI (LigAC), XhoI e HindIII (LigBC), XhoI e NcoI (LigBN). Os insertos foram purificados para posterior ligação no vetor de expressão pAE, previamente digerido com enzimas de restrição apropriadas. Este vetor é derivado do pRSET (Invitrogen) e possui código de iniciação seguido de código para 6 histidinas, para futura expressão da proteína recombinante com cauda de histidinas na posição N-terminal. Após transformação da cepa DH5 $\alpha$ de $E$. coli, 
os clones positivos foram selecionados para extração plasmidial. A digestão dos mesmos com enzimas de restrição confirmou a presença dos insertos subclonados (Figura 17).

Figura 17 - Análise dos plasmídeos contendo o inserto

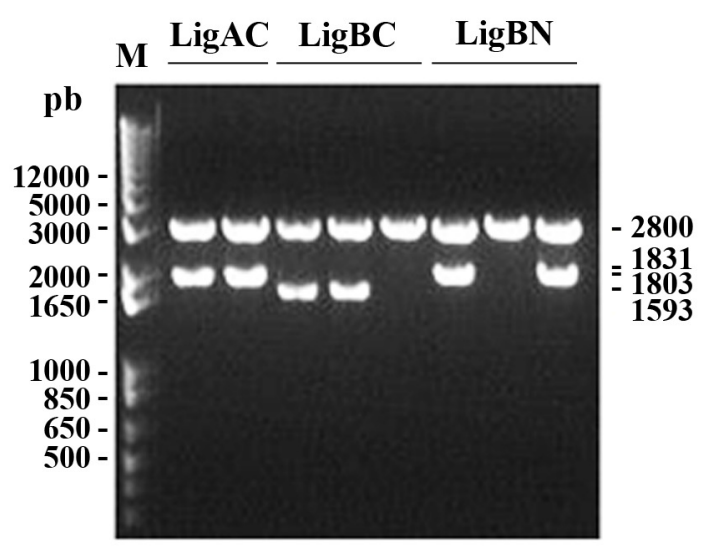

Vetor pAE (2800 pb) com os insertos liberados com enzimas de restição BamHI e NcoI para obtenção de LigAC (1803 pb), XhoI e HindIII para LigBC (1593 pb), XhoI e NcoI LigBN (1831 pb). M - marcador de tamanho em pares de base (pb) (1 kb plus DNA ladder, Invitrogen).

\subsection{Sequenciamento dos clones}

Todas as construções foram sequenciadas. Na análise das sequências observamos que todos os fragmentos haviam sido clonados corretamente. Os insertos não apresentaram deleções, mutações ou inserções que pudessem alterar as características da proteína. As colônias escolhidas para a futura expressão das proteínas recombinantes foram preservadas a $80{ }^{\circ} \mathrm{C}$ em meio LB contendo $40 \%$ de glicerol estéril.

4.5 Expressão e purificação das proteínas recombinantes LigAC, LigBC e LigBN

A análise da expressão das proteínas foi feita por eletroforese em gel de poliacrilamida (SDS-PAGE), utilizando as frações solúveis ou insolúveis dos controles induzidos e não induzidos lisados por sonicação (Figuras 18). 
Figura 18 - Análise da expressão das proteínas LigAC, LigBC e LigBN por SDS-PAGE 12\%
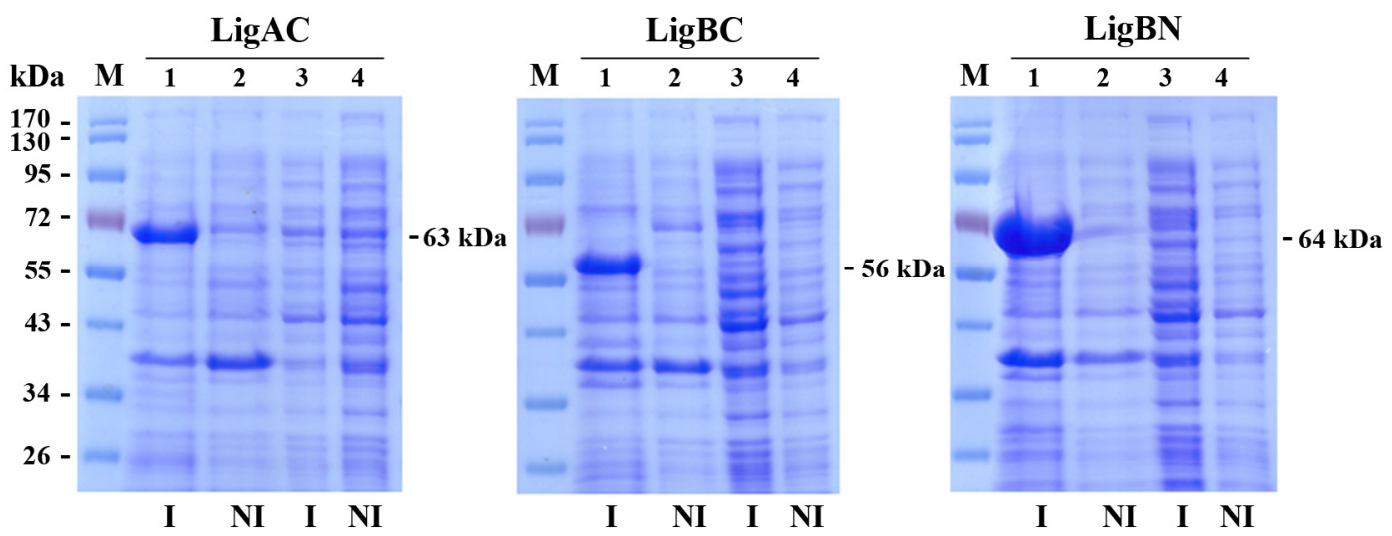

Indução da expressão das proteínas recombinantes LigAC, LigBC e LigBN na cepa bacteriana de $E$. coli BL21(SI). Controles induzido (I) e não induzido (NI) das frações insolúveis $(1,2)$ e solúveis $(3,4)$. (M) marcador de massa molecular (Page ruler, Fermentas).

A expressão das proteínas de interesse foi bem sucedida na cepa bacteriana E. coli BL21(SI). Todas as proteínas foram encontradas majoritariamente na porção insolúvel em forma de corpúsculos de inclusão (Figura 18). O acúmulo de proteínas nestes corpúsculos é uma característica importante do sistema de expressão em E. coli. Embora os fatores que contribuem para sua formação não sejam ainda completamente entendidos, evidências sugerem que altas concentrações de proteínas produzidas por promotores fortes levariam ao acúmulo de cadeias polipeptídicas nascentes com conformação não nativa, favorecendo a sua agregação e, portanto, a formação de corpúsculos (Marston, 1986). Todas as proteínas expressas apresentaram os tamanhos esperados, segundo predição feita no programa Gene runner.

A proteína LigAC, LigBC e LigBN foram purificadas por cromatografia de afinidade (Figura 19), após indução na bactéria BL21(SI). Foram eluídas com soluções contendo 20 $\mathrm{mM}, 40 \mathrm{mM}, 60 \mathrm{mM}, 100 \mathrm{mM}$ e $1 \mathrm{M}$ de imidazol como agente competidor. A proteína LigAC foi eluída nas frações de $60 \mathrm{mM}$ e $100 \mathrm{mM}$ de imidazol sem presença de contaminantes. A concentração estimada da proteína foi $0,125 \mu \mathrm{g} / \mu 1$.

A proteína LigBC foi eluída nas concentrações de $40 \mathrm{mM}, 60 \mathrm{mM}$ e $200 \mathrm{mM}$ de imidazol. A eluição desta proteína não indicou presença forte de contaminantes. Por esta razão, decidimos juntar todas estas frações e concentrá-las por ultrafiltração no sistema de células de agitação Amicom. As amostras concentradas foram analisadas por SDS-PAGE. Depois de concentrada, a proteína foi dialisada em PBS, aliquotada e estocada a $-80{ }^{\circ} \mathrm{C}$. A concentração da proteína foi $0,1 \mu \mathrm{g} / \mu \mathrm{l}$. 
A purificação da proteína LigBN apresentou alguns obstáculos, pois, apesar da boa expressão e eluição, ela se apresentou instável após diálise ou concentração das frações purificadas, dificultando sua obtenção. Decidimos então purificá-la, realizando consecutivamente todas as etapas, sem congelamentos. A proteína foi purificada a partir da fração insolúvel dos lisados bacterianos e eluída com imidazol nas concentrações de $60 \mathrm{mM} \mathrm{e}$ $200 \mathrm{mM}$. As frações contendo as proteínas foram agrupadas, concentradas e dialisadas contra PBS e avaliadas antes e após concentração e diálise. A concentração final estimada da proteína foi $0,09 \mu \mathrm{g} / \mu 1$.

A concentração das proteínas Ligs foi determinada por densitometria óptica, utilizando o programa Quantity One para quantificar a densidade das bandas após SDS-PAGE. Como padrão foi empregado BSA em diversas concentrações. Um exemplo do SDS-PAGE empregado para a determinação da concentração da proteína LigBC e apresentado na Figura 20.

Figura 19 - Análise por SDS-PAGE da purificação por cromatografia de afinidade das proteínas LigAC, LigBC e LigBN

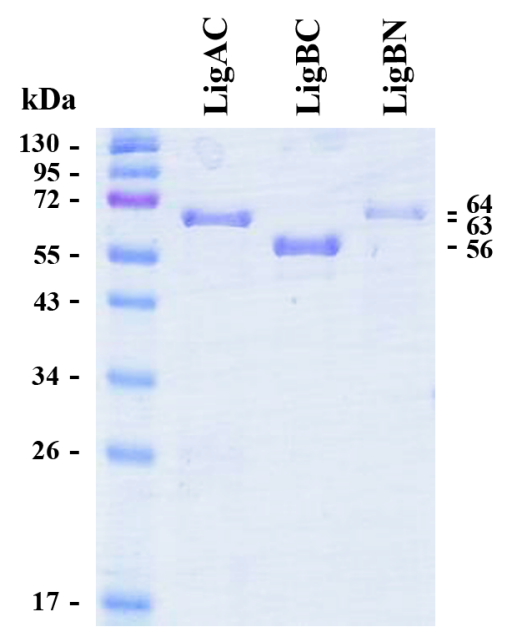

Proteínas LigAC (63 kDa), LigBC (56 kDa) e LigBN (64 kDa), após processo de purificação concentração e diálise contra PBS. As três proteínas foram obtidas sem indicação de presença forte de contaminantes (M) marcador de massa molecular (Page ruler, Fermentas). 
Figura 20 - Determinação da concentração de LigBC por densitometria óptica

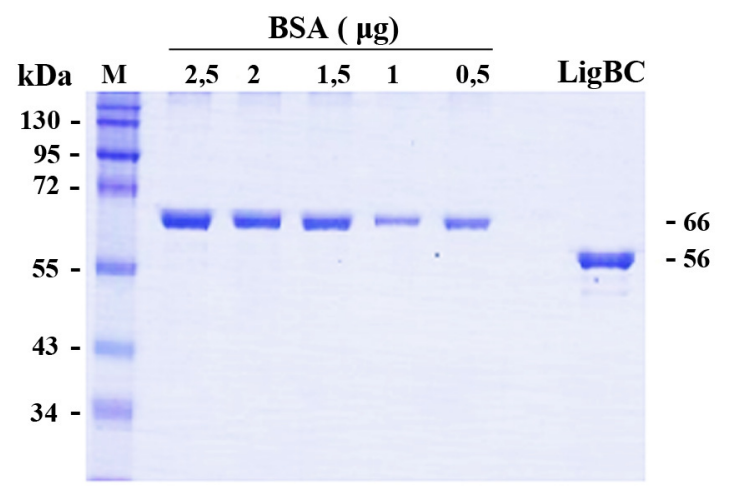

Concentrações decrescentes de BSA $(2,5 ; 2,0 ; 1,5 ; 1,0 ; 0,5 \mu \mathrm{g})$, preparação da proteína LigBC, após concentração (B). (M) marcador de massa molecular (Page ruler, Fermentas).

4.6 Avaliação da produção de soros hiperimunes obtidos em camundongos

Camundongos BALB/c fêmeas com seis semanas de idade foram submetidos a três imunizações, realizadas com intervalos de 15 dias. Duas coletas de soro foram feitas: uma antes das imunizações para obtenção de soro pré-imune e outra 15 dias após a última imunização. Os soros analisados por ELISA (Figura 21) apresentaram um título de anticorpos de aproximadamente 1:50000 para as três proteínas (LigAC, LigBC, LigBN), demonstrando assim que as proteínas são imunogênicas. Estes anticorpos foram utilizados como ferramentas de análise em ensaios posteriores. 
Figura 21 - Determinação do titulo de anticorpos de camundongos imunizados com as proteínas recombinantes LigAC, LigBC e LigBN


No total foram feitas três imunizações com intervalos de 15 dias. Os soros coletados antes das imunizações (préimune) foram utilizados como controle negativo. As determinações foram feitas por ELISA. As três proteínas foram capazes de induzir a produção de anticorpos IgG específicos com similar grau de imunogenicidade.

4.7 Análise da interação de Leptospira interrogans com FH, FHL-1 e FHR-1 e da atividade de co-fator

Dados prévios mostraram que leptospiras patogênicas interagem com FH e com FHR$1 \alpha / \beta$ presentes no soro humano (Meri et al., 2005). No entanto, para determinar mais precisamente quais proteínas da família do $\mathrm{FH}$ interagem com L. interrogans, as bactérias foram incubadas com FH purificado, FHL-1 ouFHR-1 recombinantes. Após várias lavagens, os precipitados celulares foram analisados por Western blot com anti-FH. Bandas correspondentes a FH (150 kDa), rFHL-1 (43 kDa) e rFHR-1 (42 kDa) foram detectadas, indicando que leptospiras patogênicas interagem com pelo menos três dos membros da família do FH (Figura 22A). A atividade de cofator do FH e do rFHL-1 ligados às bactérias foi analisada pela clivagem de C3b mediada pelo FI. Como era esperado, FI cliva a cadeia $\alpha^{\prime}$ 
(110 kDa) de C3b na presença de FH ou rFHL-1, gerando fragmentos desde $28 \mathrm{kDa}$ a $46 \mathrm{kDa}$ (Figura 22B). A clivagem foi muito mais eficiente na presença de FH, como indicado pelo completo desaparecimento da cadeia $\alpha$ '. Degradação de C3b também foi observada na ausência de cofator, indicando que leptospiras secretam proteases capazes de degradar C3b (Fraga et al., 2013) (Figura 22B). Uma vez que a clivagem de C3b na presença de FHL-1 não difere daquela observada na ausência de qualquer cofator, concluí-se que esta clivagem seja consequência da atividade inerente da bactéria.

Figura 22 - Interação de L. interrogans com FH, FHL-1 e FHR-1

A.

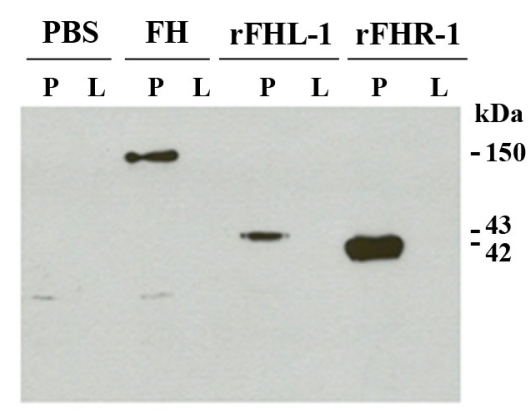

B.

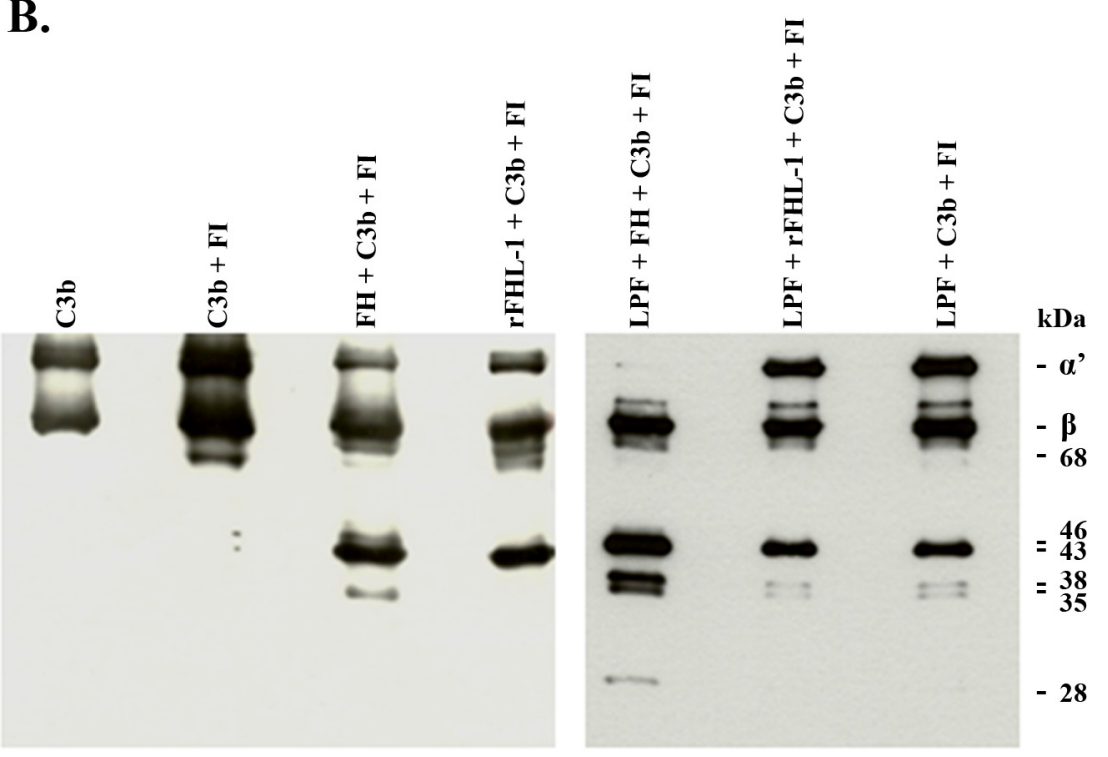

L. interrogans sorovar Kennewicki, estirpe Pomona Fromm (LPF) foi incubada com $2 \mu \mathrm{g}$ de FH purificado e com as proteínas recombinantes FHL-1, FHR-1 ou PBS; os lisados foram analisados por Western blot empregando anti-FH. (P) precipitados bacterianos; (L) alíquota da última lavagem. Bandas correspondentes a FH $(150 \mathrm{kDa})$, rFHL-1 (43 kDa) e rFHR-1 (42 kDa) foram detectadas com anti-FH policlonal (A). LPF foi incubada com $2 \mu \mathrm{g}$ de FH, rFHL-1, ou na ausência de qualquer cofator. Após várias lavagens, C3b e FI foram adicionados e incubados por $2 \mathrm{~h}$. Os produtos da incubação foram submetidos à SDS-PAGE em condições redutoras, transferidos para membranas de nitrocelulose e detectados com anti-C3 policlonal. Fragmentos de clivagem de C3b de 28 a $68 \mathrm{kDa}$ foram obtidos. Os controles da reação sem bactéria são apresentados à esquerda (B). 
4.8 Análise da interação de proteínas de membrana de L. interrogans com FH e C4BP

Uma vez tendo expressado e purificado as proteínas de interesse de L. interrogans (Tabela 1), fomos investigar quais delas seriam capazes de interagir com as proteínas $\mathrm{FH}$ e C4BP e quais delas estariam envolvidas com os mecanismos de evasão desta bactéria ao sistema complemento humano. A interação destas proteínas com reguladores do complemento foi analisada por Western blot e por ELISA.

\subsubsection{Western blot com sobreposição}

As proteínas recombinantes de Leptospira (Tabela 1) foram submetidas à eletroforese (SDS-PAGE 12\%), transferidas para membranas de nitrocelulose e coradas com Ponceau. BSA foi usado como controle negativo de ligação das proteínas ao $\mathrm{FH}$, e C3b como controle positivo. As membranas foram incubadas com $10 \%$ de soro humano normal como fonte de FH (a concentração sérica de FH é aproximadamente $443 \pm 106 \mu \mathrm{g} / \mathrm{ml}$; De Paula et al., 2003). A detecção desta molécula ligada às proteínas recombinantes foi realizada com anti-FH humano produzido em coelho.

Os resultados indicam que as proteínas codificadas pelas LIC10657 e LIC11087, assim como os fragmentos C-terminais das Ligs A e B e o fragmento N-terminal comum a ambas interagiram com FH (Figura 23). Visto que as proteínas Ligs são importantes ligantes de componentes de matriz extracelular, e que, além de interagir com FH também apresentaram interação com C4BP confirmada por vários ensaios independentes de Western blot com sobreposição, decidimos caracterizar essa ligação em maior profundidade, conforme mostrado nos ensaios que se seguem. 
Figura 23 - Análise da interação de FH com as proteínas recombinantes de Leptospira por Western blot com sobreposição

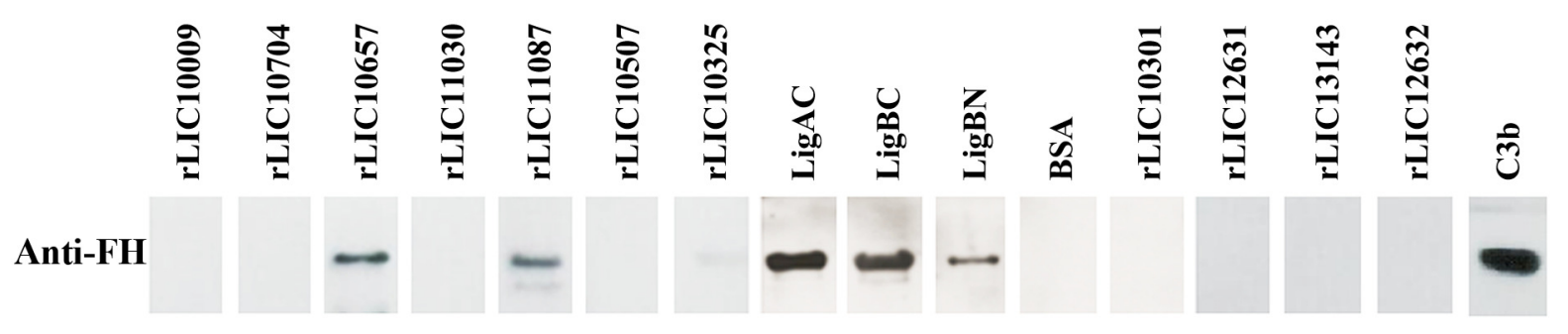

Após eletroforese sem redução, as proteínas recombinantes foram transferidas para membrana de nitrocelulose. As membranas foram incubadas com SHN $10 \%$ como fonte de FH. A deteç̧ão foi feita com anticorpo (policlonal) anti-FH. C3b (1 $\mu \mathrm{g})$ foi usado como controle positivo da interação.

A interação das proteínas recombinantes (Tabela 1) com C4BP também foi analisada por Western blot com sobreposição (Figura 24). Apenas as proteínas Ligs interagiram com C4BP.

Figura 24 - Análise da interação das proteínas Ligs com C4BP

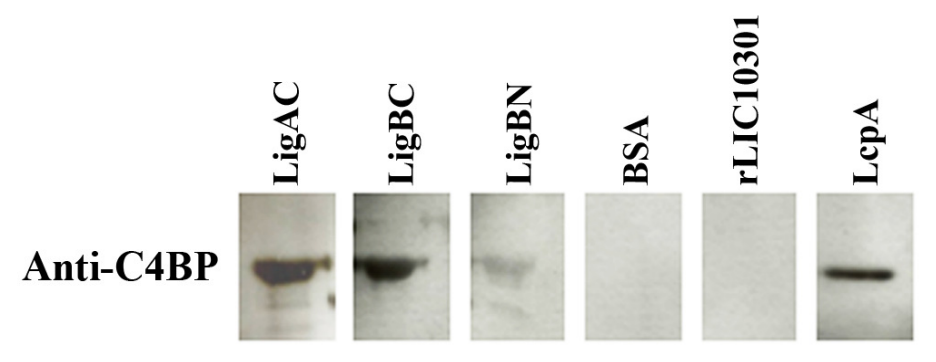

As proteínas $\operatorname{LigAC}$, $\operatorname{LigBC}$ e $\operatorname{LigBN}$ foram submetidas a SDS-PAGE, e transferidas para membranas de nitrocelulose. As membranas foram incubadas com C4BP purificado, o qual foi detectado com anticorpos específicos. BSA e rLIC10301 foram usados como controles negativos e LcpA foi incluída como controle positivo de ligação ao C4BP (Barbosa et al., 2010).

\subsubsection{ELISA}

A interação das proteínas recombinantes Ligs com os reguladores do complemento $\mathrm{FH}$ e C4BP foi também analisada por ELISA. LigAC, LigBC e LigBN foram imobilizadas em placas e incubadas com FH ou C4BP em diferentes concentrações $(1,25 \mu \mathrm{g} ; 2,5 \mu \mathrm{g} ; 5 \mu \mathrm{g})$. As três proteínas interagiram de maneira dose-dependente com os dois reguladores (Figura 25), 
confirmando os resultados obtidos por Western blot. A proteína codificada pela LIC10301 e BSA foram usadas como controles negativos de ligação.

Neste experimento a interação das proteínas Ligs com C4BP atingiu uma saturação rápida com 2,5 $\mu \mathrm{g}$ deste regulador, ao passo que nas semelhantes condições empregadas, estas mesmas proteínas não atingiram saturação com FH. Conforme esperado, as proteínas LIC10301 e BSA não interagiram com FH ou com C4BP.

Figura 25 - Análise da interação das proteínas Lig com os reguladores do complemento FH e C4BP por ELISA
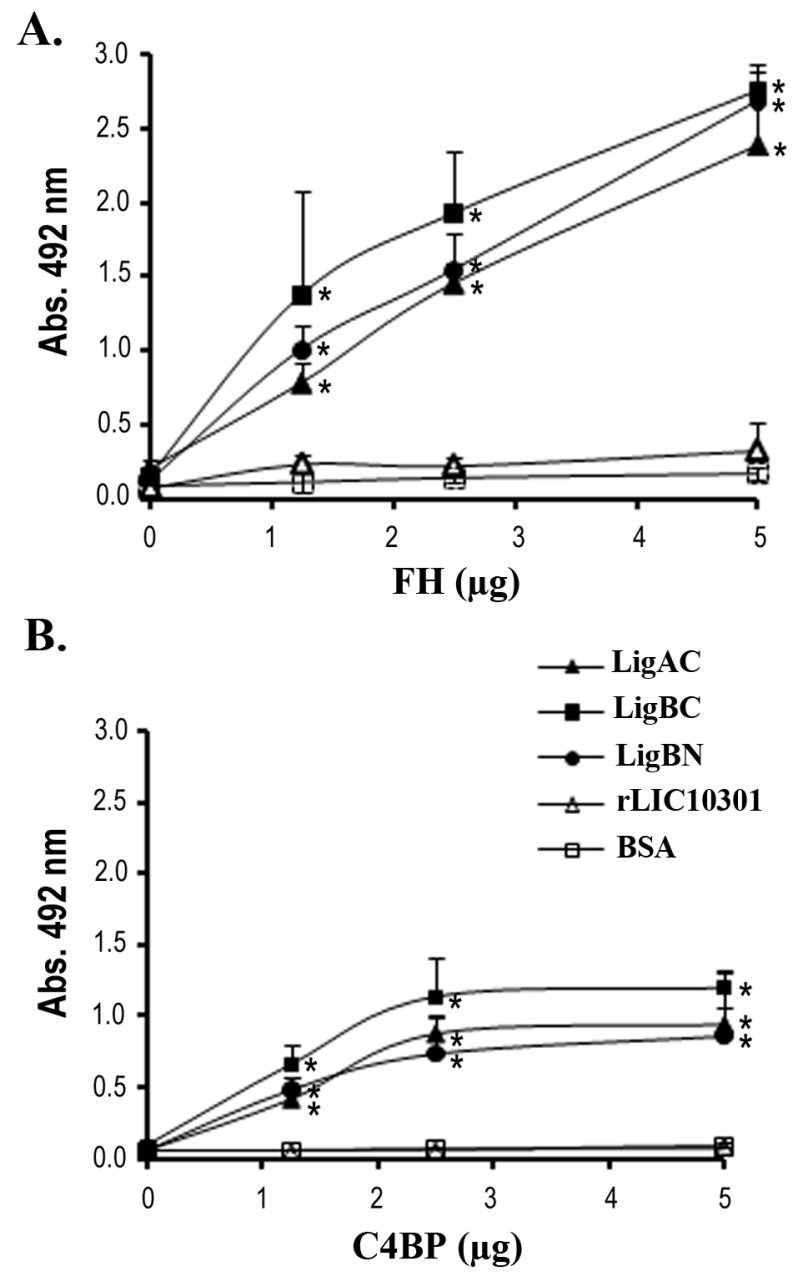

Proteínas recombinantes $\operatorname{LigAC}$, LigBC, $\operatorname{LigBN}(1 \mu \mathrm{g})$ foram imobilizadas em placas e incubadas com diferentes concentrações $(1,25 ; 2,5$ e $5 \mu \mathrm{g})$ de FH (A) ou C4BP (B) e detectadas com anticorpos específicos. LIC10301 e BSA foram usadas como controles negativos de ligação. Cada ponto representa uma media do valor de absorbância a $492 \mathrm{~nm}$ de 3 experimentos diferentes. A ligação de FH ou C4BP nas proteínas recombinantes foi comparada com a ligação destas moléculas em BSA. A análise estatística foi feita empregando-se o test $t$ de Student. * $(p<0.005)$. 
4.9 Avaliação da atividade de co-fator do FH e C4BP ligado às proteínas de membrana $L$. interrogans

Após confirmação da ligação das proteínas Ligs, rLIC11087, rLIC10657 ao FH e das proteínas $\operatorname{LigAC}$, LigBC e LigBN a C4BP, investigou-se se tais reguladores manteriam suas atividades como co-fatores de FI na clivagem de $\mathrm{C} 3 \mathrm{~b}$ e $\mathrm{C} 4 \mathrm{~b}$ respectivamente. Para isto, rLIC11087, rLIC10657, LigAC, LigBC e LigBN foram incubadas com FH ou C4BP e, após várias lavagens, adicionou-se C3b ou C4b, e FI. As incubações prosseguiram por 1, 2 ou 4h. A proteína LIC10301 e também as proteínas recombinantes mencionadas anteriormente, sem incubação prévia com $\mathrm{FH}$ ou $\mathrm{C} 4 \mathrm{BP}$, foram empregadas como controles negativos. Os fragmentos resultantes da clivagem de $\mathrm{C} 3 \mathrm{~b}$ ou $\mathrm{C} 4 \mathrm{~b}$ foram analisados por Western blot com anticorpos específicos.

Quando as Ligs foram incubadas tanto com a proteína purificada, quanto com soro como fonte de FH, a clivagem de $\mathrm{C} 3 \mathrm{~b}$ pelo FI foi considerada eficiente. Em todos os casos pode-se observar a presença dos fragmentos de $68 \mathrm{kDa}, 46 \mathrm{kDa}$ e $43 \mathrm{kDa}$ gerados pela clivagem enzimática de C3b (Figura 26). A presença de uma banda de $68 \mathrm{kDa}$ foi também observada quando empregamos a proteína LIC10301 e poderia ser atribuída à degradação inespecífica de C3b pelo FI na ausência de FH.

Os resultados também mostram que tanto o FH purificado quanto aquele oriundo do soro ligados às proteínas LIC11087 e LIC10657 retêm sua atividade como co-fator do FI na clivagem de C3b (Figura 27). Foram produzidos fragmentos de 46 e $43 \mathrm{kDa}$ que indicam a clivagem de C3b. A molécula de C3b apresentou um pouco de degradação espontânea inespecífica em todos os tratamentos, incluindo aqueles em que não havia soro ou $\mathrm{FH}$ purificado. Este fenômeno poderia ser atribuído à incubação das amostras a $96{ }^{\circ} \mathrm{C}$ para redução.

Ao avaliar a atividade de co-fator da proteína C4BP ligada às Ligs, observamos que, quando soro como fonte de C4BP é empregado, a atividade de co-fator desaparece, mas quando se usa C4BP purificada, a clivagem de C4b pelo FI, tendo C4BP como co-fator, é muito eficiente e tempo-dependente (Figura 28) sendo possível visualizar o fragmento de clivagem $\mathrm{C} 4 \mathrm{~d}$ com $45 \mathrm{kDa}$, detectado pelo anticorpo monoclonal anti-C4d que evidencia a cadeia $\alpha$ intacta de $\mathrm{C} 4 \mathrm{~b}$ e C4d. Produtos de clivagem incompleta da cadeia $\alpha$ ' de C4b também são observados na Figura 29. Não se observa a presença da banda de $45 \mathrm{kDa}$ quando a proteína LIC10301 foi empregada e nem nas amostras incubadas na ausência de C4BP 
(controles negativos). Isto confirma que os fragmentos de clivagem são produtos da atividade da proteína C4BP ligada às proteínas Ligs atuando como co-fator de FI.

Figura 26 - Análise da atividade do FH como co-fator de FI na clivagem de C3b

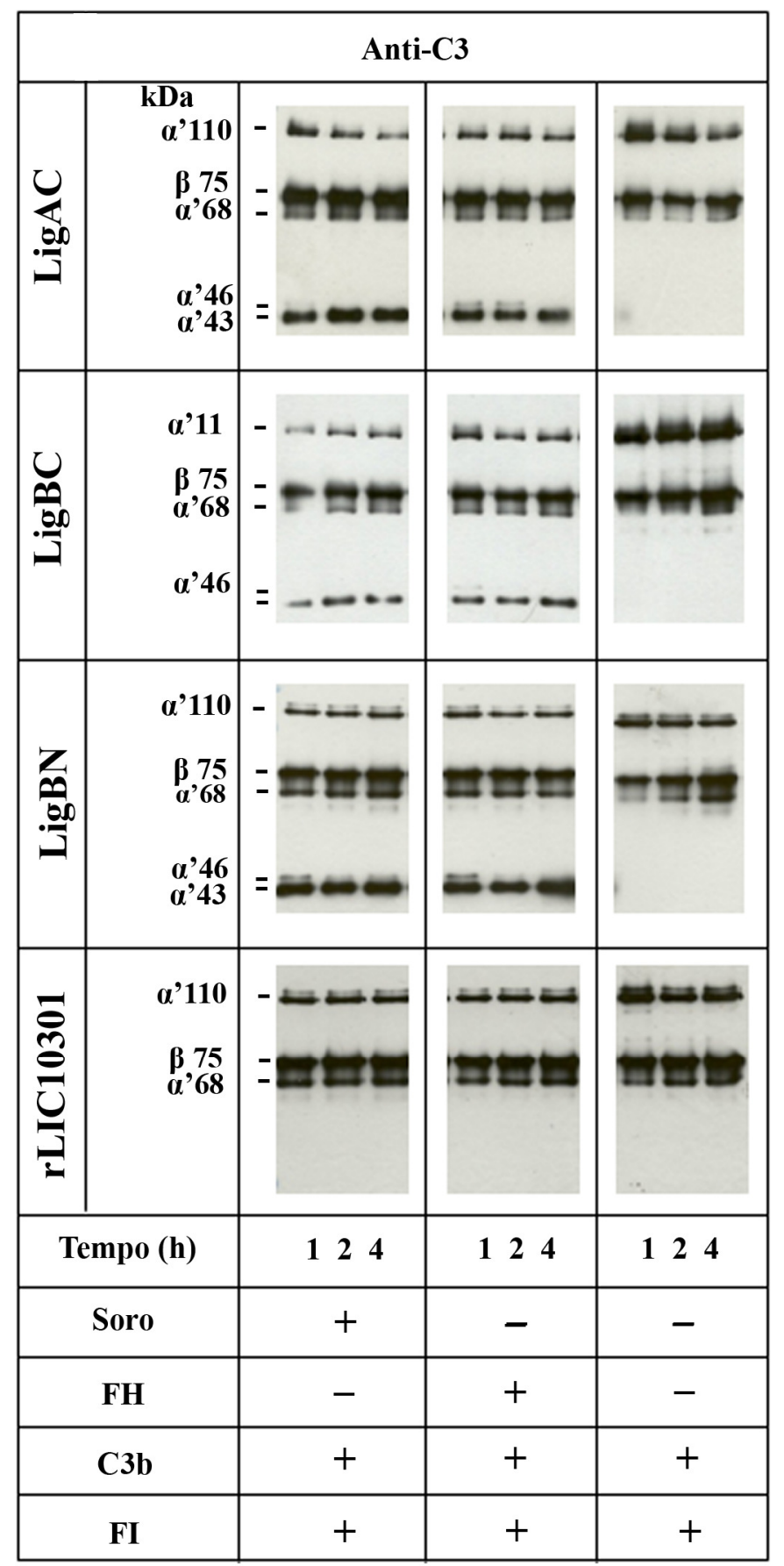

As proteínas LigAC, LigBC, LigBN e LIC10301 (1 $\mu \mathrm{g}$ por poço) foram imobilizadas em placas e incubadas com $5 \%$ de SHN como fonte de FH, com FH purificado $(2 \mu \mathrm{g})$ ou sem FH. Após lavagem, C3b (500 ng) e FI (250 ng) foram adicionados. A reação foi incubada por 1,2 e $4 \mathrm{~h}$ a $37^{\circ} \mathrm{C}$. Os produtos foram analisados por SDS-PAGE $10 \%$ e os fragmentos de clivagem de $\mathrm{C} 3 \mathrm{~b}$ foram detectados por Western blot com anti- C3 policlonal. LigAC, LigBC e LigBN foram capazes de ligar $\mathrm{FH}$ o qual retém sua atividade de co-fator na clivagem de $\mathrm{C} 3 \mathrm{~b}$, produzindo fragmentos de $68 \mathrm{kDa}(\mathrm{iC} 3 \mathrm{~b}), 46 \mathrm{kDa}, 43 \mathrm{kDa}$. LIC10301 foi usada como controle negativo. 
Figura 27 - Análise da atividade do FH ligado a proteínas recombinantes LIC11087 e LIC10657 como co-fator de FI na clivagem de C3b

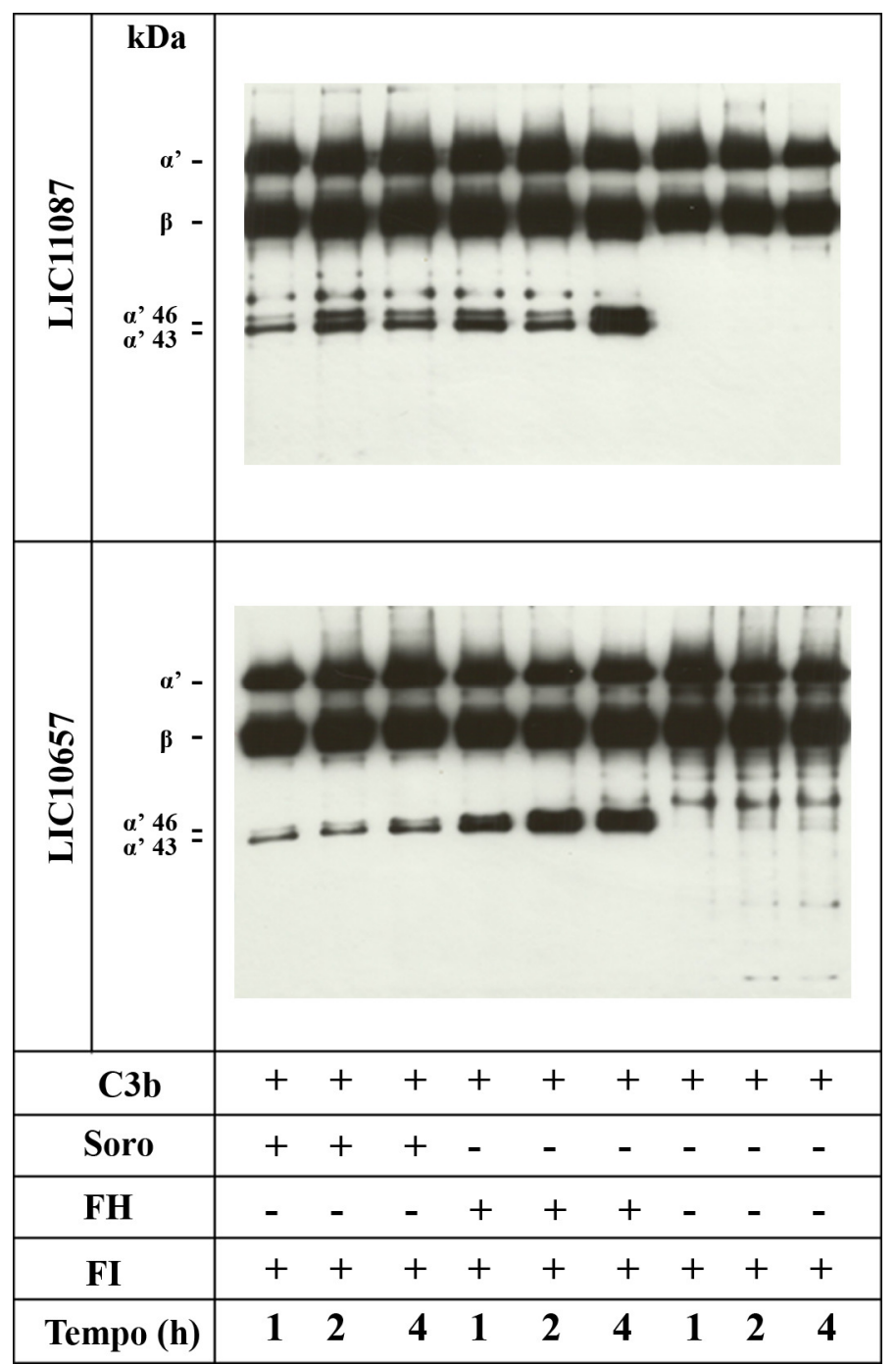

As proteínas bacterianas LIC11087 e LIC10657 (1 $\mu \mathrm{g}$ por poço) foram imobilizadas em placas e incubadas com $5 \%$ de SHN como fonte de FH, com FH purificado ( $2 \mu \mathrm{g})$ ou sem FH. Após lavagens, C3b (500 ng) e FI (250 ng) foram adicionados. A reação foi incubada por 1,2 e $4 \mathrm{~h}$ a $37^{\circ} \mathrm{C}$. Os produtos foram analisados por SDSPAGE $12 \%$ e os fragmentos de clivagem de $\mathrm{C} 3 \mathrm{~b}$ foram detectados por Western blot com anti-C3 policlonal. LIC11087 e LIC10657 foram capazes de ligar FH o qual retém sua atividade de co-fator na clivagem de C3b, gerando fragmentos de $43 \mathrm{e} 46 \mathrm{kDa}$. 
Figura 28 - Análise da atividade de C4BP como co-fator de FI na clivagem de C4b

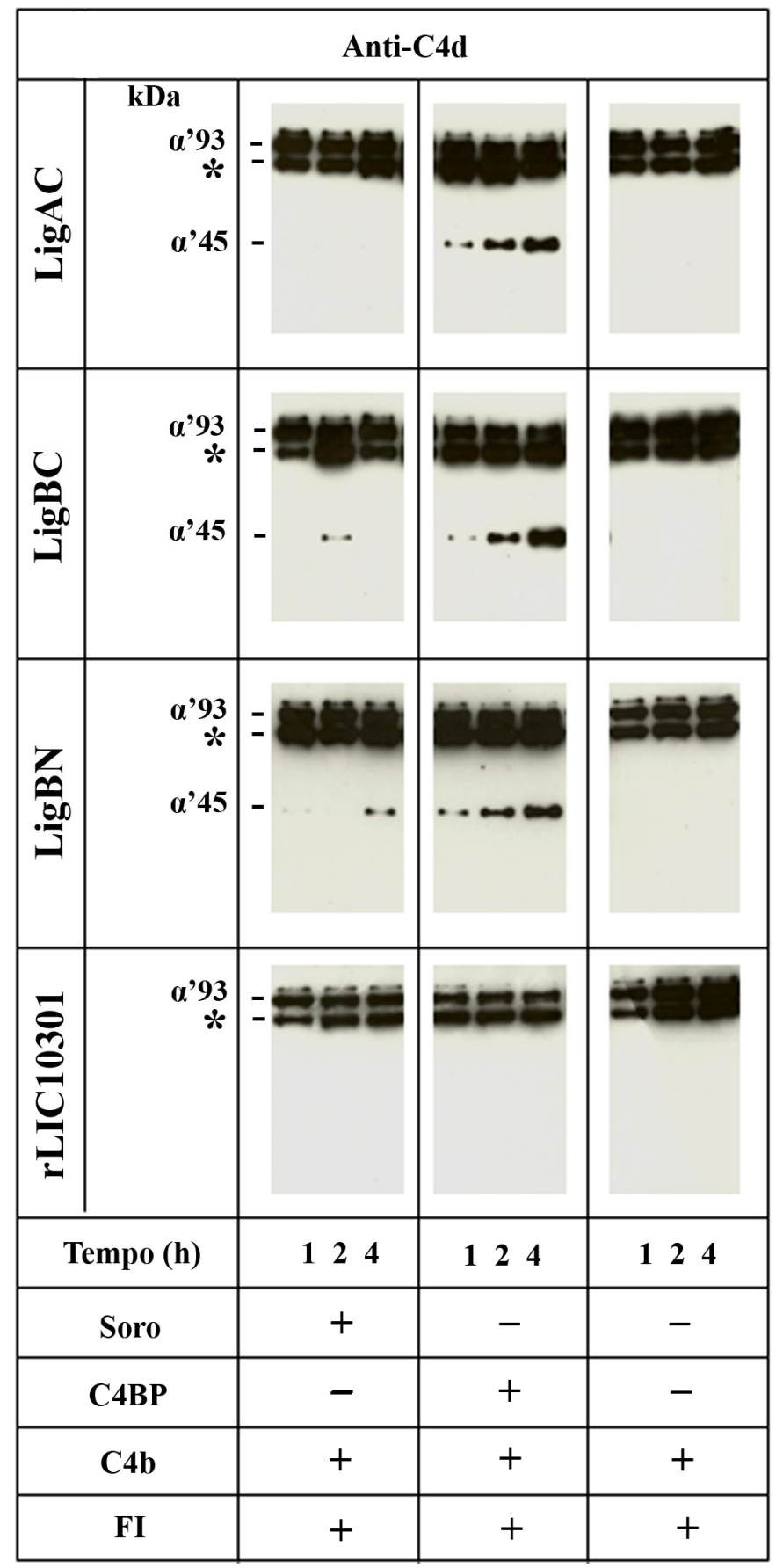

As proteínas $\operatorname{LigAC}$, LigBC, $\operatorname{LigBN}$ e LIC10301 (1 $\mu \mathrm{g}$ por poço) foram imobilizadas em placas e incubadas com $5 \%$ de SHN como fonte de C4BP, com C4BP purificado $(2 \mu \mathrm{g})$ ou sem C4BP. Após lavagem, C4b (500 ng) e FI $\left(250 \mathrm{ng}\right.$ ) foram adicionados. A reação foi incubada por 1,2 e $4 \mathrm{~h} \mathrm{a} 37^{\circ} \mathrm{C}$. Os produtos foram analisados por SDS-PAGE $10 \%$ e os fragmentos de clivagem de $\mathrm{C} 4 \mathrm{~b}$ foram detectados por Western blot com anticorpo monoclonal anti- C4d. LigAC, LigBC e LigBN foram capazes de ligar C4BP o qual retém sua atividade de cofator na clivagem de $\mathrm{C} 4 \mathrm{~b}$, resultando em fragmentos de aproximadamente $68 \mathrm{kDa}$ (*- produto derivado de clivagens parciais da cadeia $\alpha$ de C4b) e $45 \mathrm{kDa}$ (correspondente a C4d). 


\subsection{Ensaio de Competição}

Uma vez tendo demonstrado que as proteínas LigA e LigB de L. interrogans ligam-se aos reguladores FH e C4BP do sistema complemento, investigamos se estes reguladores competiriam pelos mesmos sítios de ligação na bactéria. Para responder a esta questão, proteínas LigAC, LigBC e LigBN $(1 \mu \mathrm{g})$ foram imobilizadas em placas de ELISA e incubadas com $1 \mu \mathrm{g}$ de FH e com C4BP em diferentes concentrações $(0,25 ; 0,5 ; 1 ; 2 ; 4 \mu \mathrm{g})$. Os ensaios foram realizados em duplicata de forma que as proteínas reguladoras do sistema complemento pudessem ser detectadas com anticorpos específicos (Figura 29).

Nas condições realizadas, quantidades elevadas de C4BP não afetaram a interação entre as Ligs e FH, sugerindo que possivelmente estas moléculas possuam sítios distintos de ligação. Resultados similares também foram obtidos quando foram usadas concentrações saturáveis de C4BP (5 $\mu \mathrm{g})$ e FH (dados não mostrados).

Figura 29 - Análise da competição entre FH e C4BP por sítios de ligação nas proteínas Ligs


As proteínas LigAC, LigBC e LigBN foram imobilizadas em placas e incubadas ao mesmo tempo com FH (1 $\mu \mathrm{g})$ e C4BP em diferentes concentrações $(0,25 ; 0,5 ; 1 ; 2 ; 4 \mu \mathrm{g})$ para determinar possível competição entre estes dois reguladores. Ambas as proteínas foram detectadas com anticorpos específicos para cada uma. A razão molar sublinhada é aquela encontrada no soro em condições fisiológicas. 
4.11 Avaliação do efeito protetor de FH na sobrevivência de L. interrogans Pomona

Logo após a entrada no hospedeiro, as bactérias são capazes de ativar a via alternativa do complemento. A habilidade de leptospiras patogênicas (virulentas) em evadir ao ataque do complemento já havia sido descrita há muitos anos (Cinco, Banfi, 1983; Johnson, Harris, 1967). Mais recentemente, demonstrou-se que cepas patogênicas são capazes de sequestrar FH do soro do hospedeiro como mecanismo de evasão (Meri et al., 2005). Para melhor avaliar o papel protetor do FH ligado à superfície da leptospira, a cepa L. interrogans sorovar Pomona Fromm, previamente caracterizada como resistente ao soro (Barbosa et al., 2009), foi incubada em soro depletado de $\mathrm{FH}$ ou neste mesmo soro reconstituído com diferentes quantidades de FH, atingindo-se concentrações fisiológicas $(500 \mu \mathrm{g} / \mathrm{ml})$. A adição de $\mathrm{FH}$ ao soro depletado aumentou de forma significativa a sobrevivência bacteriana, conferindo um efeito protetor dose-dependente (Figura 30). A sobrevivência bacteriana foi arbitrariamente estipulada com $100 \%$ quando se utilizou soro depletado de FH reconstituído com $500 \mu \mathrm{g}$ de FH purificado (média da concentração sérica em adultos normais: $443 \pm 106 \mu \mathrm{g} / \mathrm{ml}$ ) De paula et al., 2003).

Figura 30 - Avaliação do efeito protetor do FH na sobrevivência de leptospiras patogênicas

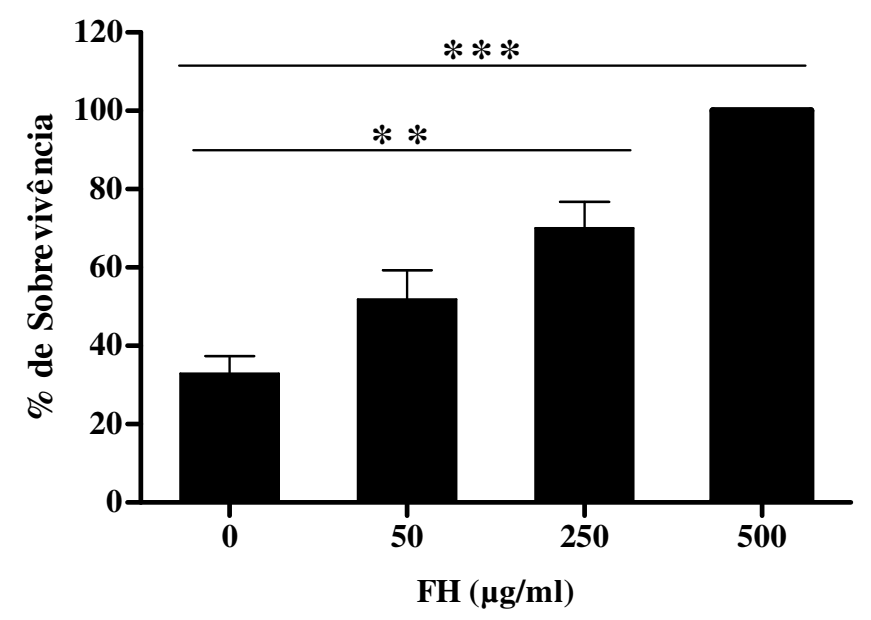

Suspensões de L. interrogans Pomona (LPF) foram incubadas com soro humano depletado de FH e reconstituído com quantidades crescentes de FH purificado (50-500 $\mu \mathrm{g})$. A sobrevivência foi analisada pela contagem das bactérias viáveis usando microscópio de campo escuro. Os dados representam a média de 3 experimentos. Teste estatístico ANOVA, * $(p<0,05)$. 
4.12 Interação das proteínas Lig com outras proteínas da família do FH

Os resultados mostraram que, além de interagir com $\mathrm{FH}$, as proteínas Ligs também interagem com FHR-1, FHL-1 e esta interação com FH ocorre provavelmente através dos SCRs 5-7 e SCRs 18-20 (Figura 32A).

Para confirmar a interação de alguns dos SCRs do FH com as Ligs, a proteína LigBC foi imobilizada na placa à qual adicionou-se FH previamente incubado com anticorpos monoclonais contra os SCR 1-4 (anti-1-4), SCR5 (OX24x), SCRs 8-14 (131x) e SCR 20 (C18 e A229) para inibir estes sítios e poder determinar quais domínios estavam envolvidos na ligação. A interação foi avaliada com anticorpo policlonal anti-FH. Os dados indicam que os SCRs 15-20 participam da interação, no que diz respeito ao FH e FHR-1. Mais uma vez excluiu-se o envolvimento dos SCRs 8-14 (Figura 32B). 
Figura 31 - Análise por ELISA da interação das proteínas Lig com os reguladores do complemento FH, FHL-1 FHR-1 e os domínios SCRs 8-14 e 15-20 do FH

A.
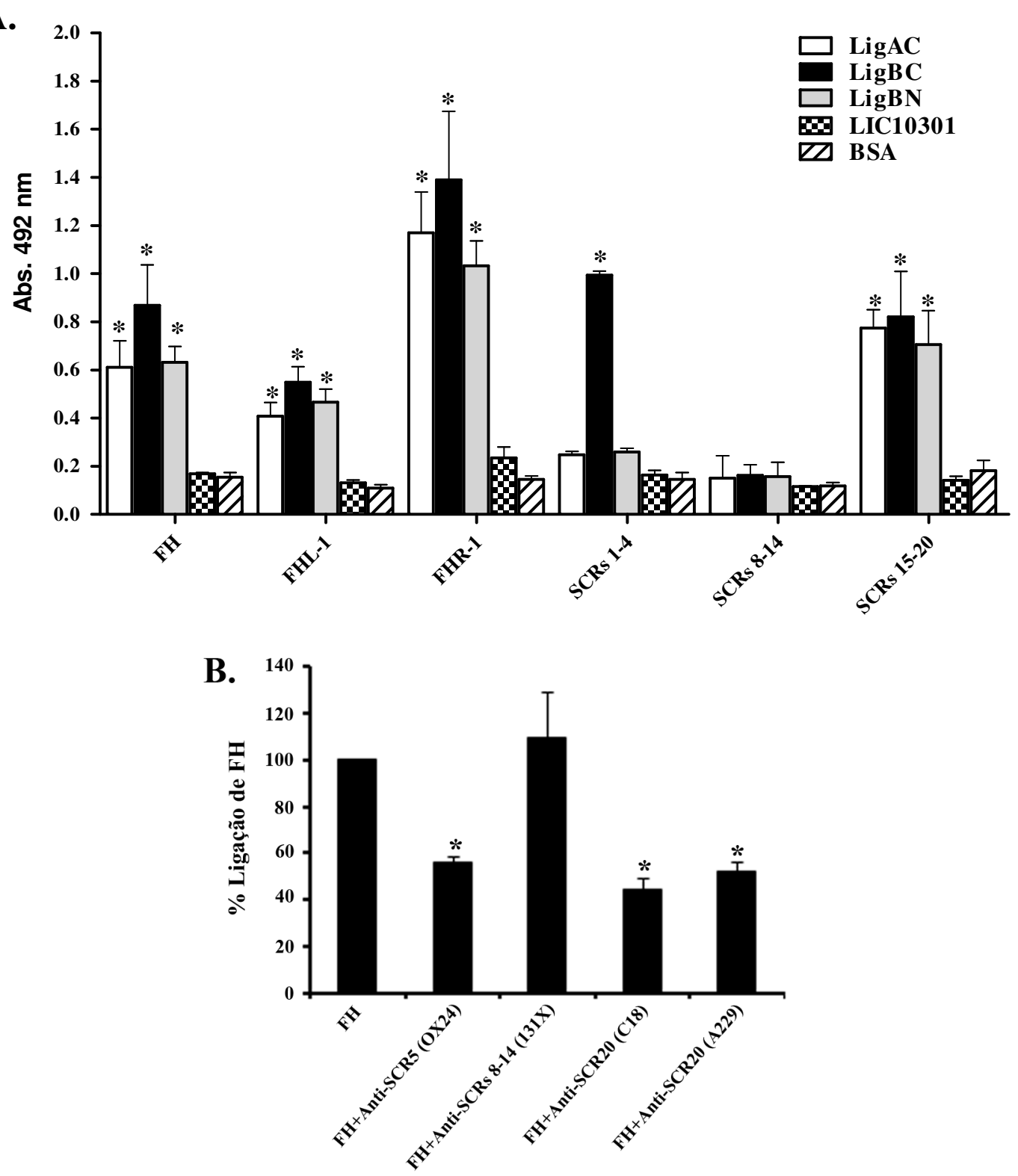

O resultado mostra uma interação menor de FHL-1, quando comparada com FHR-1 e aponta a importância dos domínios SCRs 18-20 para a interação de FH com as Ligs A e B. O FH foi usado como controle positivo. BSA e LIC10301 foram usadas como controle negativo (A). Análise da inibição da interação do FH com a proteína LigBC utilizando anticorpos monoclonais contra diferentes SCRs. A proteína LigBC imobilizada na placa foi incubada com FH previamente incubado com anticorpos monoclonais contra os SCR 1-4 (anti-1-4), SCR5 (OX24x), SCRs 8-14 (131x), SCR 20 (C18 e A229). A interação foi avaliada com anticorpo policlonal anti-FH (B). 
4.13 Sobrevivência de leptospiras transgênicas L. biflexa sorovar Patoc expressando ligA e $\operatorname{lig} B$ na presença de soro humano normal

Estudos anteriores mostraram que L. interrogans knockout para ligB não perdem sua virulência e capacidade de colonização no modelo de infecção animal. Hamsters inoculados com leptospiras mutantes para $\operatorname{lig} B$ apresentaram colonização renal eficiente e os mesmos quadros de manifestações agudas e letais da doença observados em hamsters inoculados com L. interrogans selvagens (Croda et al., 2008). Contudo, o processo de mutagênese per se dificilmente poderá evidenciar a importância de um único fator de virulência, quando existem outras proteínas de membrana, incluindo LigA, que conferem redundância funcional (Figueira et al., 2011, McBrige et al., 2008).

Para determinar a relevância desta família de proteínas como importantes fatores de virulência no processo de evasão à ação do complemento, o Dr. Claúdio Pereira Figueira da Fundação Oswaldo Cruz, Salvador, Brazil e o Dr. Albert Ko da Universidade de Yale, Estados Unidos; gentilmente cederam-nos cepas de L. biflexa transgênicas para ligA ou ligB. Tais leptospiras foram avaliadas quanto à capacidade de sobreviver na presença de diferentes quantidades de soro humano normal, comparadas com cepas de L. interrogans e L. biflexa (Figura 32). Os resultados mostraram que as leptospiras transgênicas para ligA e ligB sobrevivem melhor que a cepa selvagem (L. biflexa), indicando que a presença das proteínas LigA e LigB nas leptospiras trangênicas contribui efetivamente para maior sobrevida no hospedeiro (Figura 32).

A maior diferença na sobrevida das leptospiras transgênicas em comparação com as leptospiras selvagens foi observada quando incubadas com $60 \%$ de SHN. Esta quantidade de soro é eficiente para matar $80 \%$ das leptospiras selvagens, enquanto a mesma quantidade de soro consegue eliminar aproximadamente 50\% das leptospiras transgênicas, após 60 min de incubação.

A presença de LigA e LigB nas leptospiras transgênicas aumenta sua sobrevida, mesmo assim a sobrevida destas bactérias é menor que aquela apresentada por leptospiras patogênicas (L. interrogans). A porcentagem de sobrevivência das leptospiras patogênicas parece constante mesmo empregando diferentes concentrações de soro, já a sobrevida das leptospiras não patogênicas decresce de forma inversamente proporcional às quantidades de soro empregadas na incubação. Perfis similares foram observados com 1 ou 2 horas de incubação. 
Figura 32 - Análise da sobrevivência de leptospiras transgênicas na presença de soro humano normal

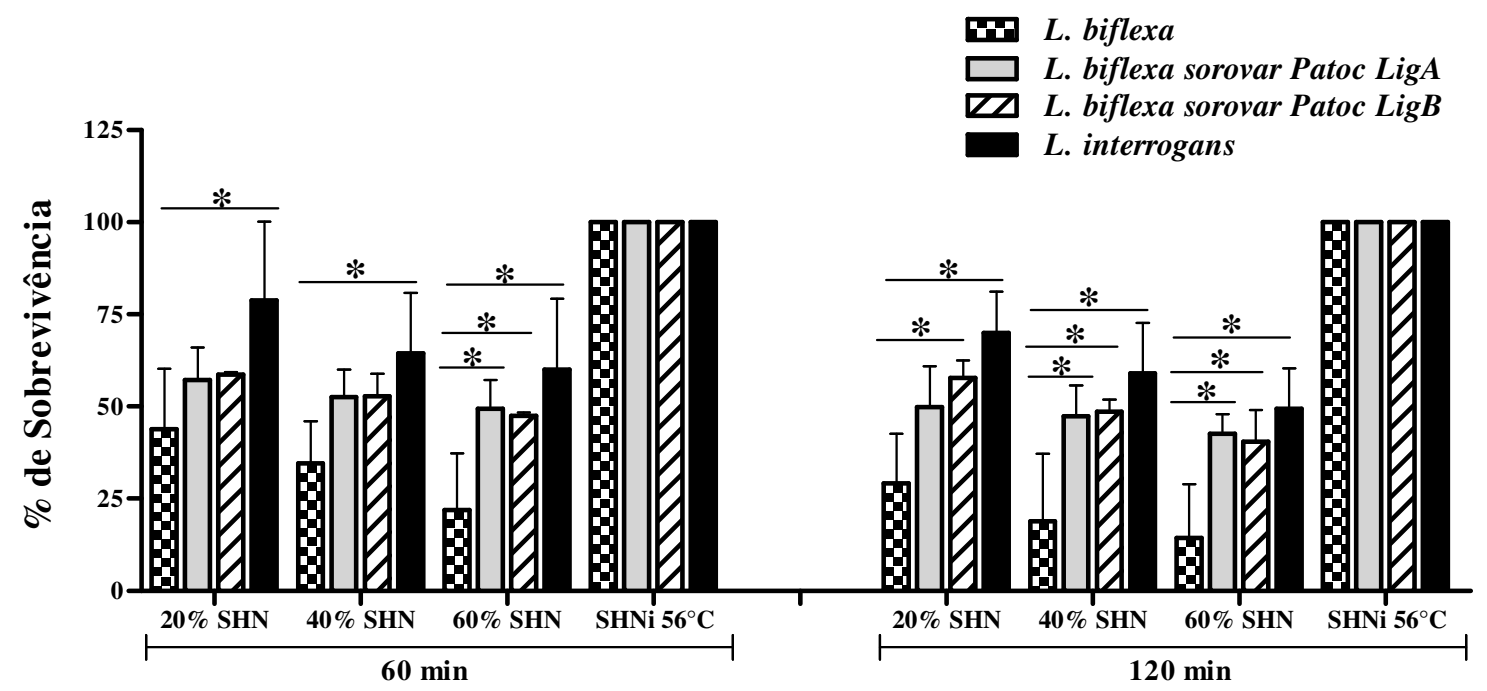

L. biflexa transgênica para LigA ou LigB, L. interrogans e L. biflexa foram incubadas por 1 e 2 horas com 20, 40 e $60 \%$ de SHN ou $60 \%$ de SHNi a $56^{\circ} \mathrm{C}$. Após incubação, as leptospiras viáveis foram contadas por microscopia de campo escuro. Estes dados representam uma média de três experimentos diferentes. A análise estatística foi feita empregando o teste ANOVA $*(p<0.05)$.

4.14 Avaliação da interação de FH e C4BP com as leptospiras transgênicas $L$. biflexa sorovar Patoc expressando ligA e $\operatorname{lig} B$

A interação de leptospiras transgênicas para LigA e LigB com FH ou C4BP foi analisada por Western blot (Figura 33A e 33B) e citometria de fluxo (Figura 33C e 33D). As bactérias foram incubadas com $20 \%$ de SHN como fonte de FH ou C4BP.

Análises por Western blot mostraram que leptospiras transgênicas para LigA e LigB, ligam-se a FH e C4BP (Figura 33A e 33B). Em ambas as figuras pode-se observar que a bactéria patogênica $L$. interrogans interage melhor com FH e C4BP comparada às leptospiras transgênicas. A L. biflexa também apresentou uma pequena interação com FH e C4BP.

As análises por citometria de fluxo mostraram que tanto $L$. interrogans quanto a $L$. biflexa transgênica para LigB interagem com C4BP. Porém, L. interrogans apresenta uma maior interação que as leptospiras transgênicas para LigB. A interação de L. biflexa selvagem ou L. biflexa transgênica para LigA com C4BP não foi significativa. Curiosamente, não foi possível detectar a interação de FH com as diferentes leptospiras empregando citometria de fluxo (dado não mostrado). 
Figura 33 - Análise da interação de FH e C4BP com leptospiras transgênicas L. biflexa sorovar Patoc expressando ligA e ligB

A.

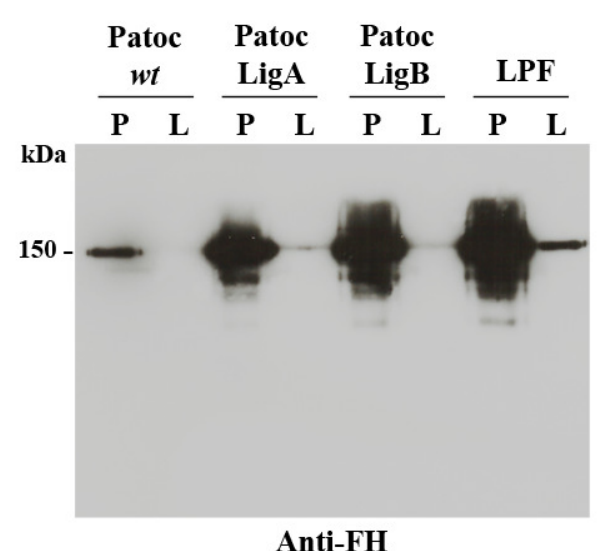

B.
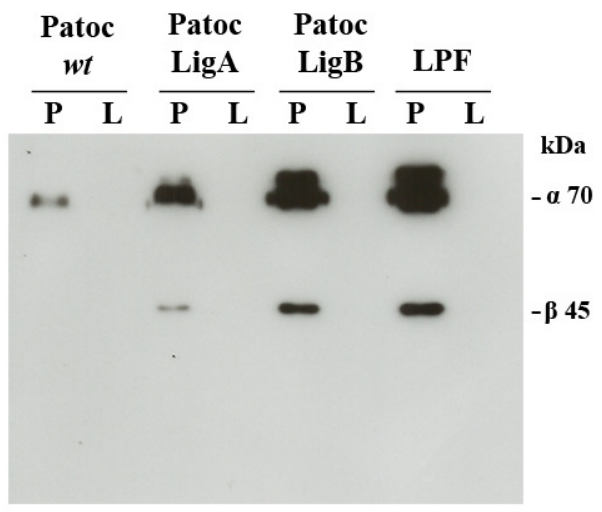

Anti-C4BP

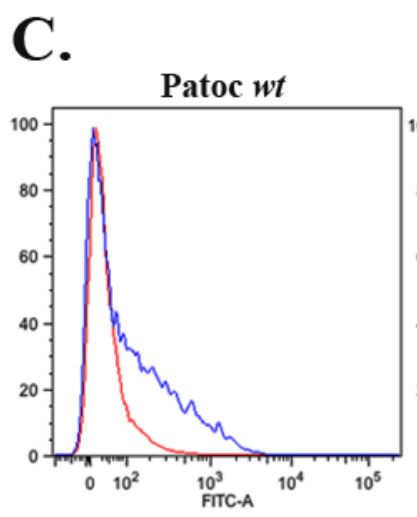

Patoc LigA

Patoc LigB

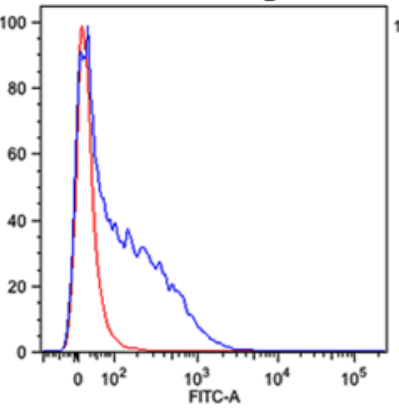



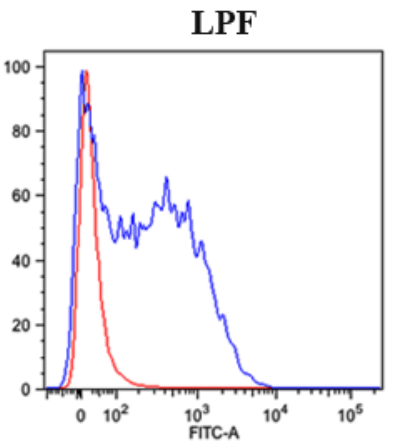

Deposição de C4BP

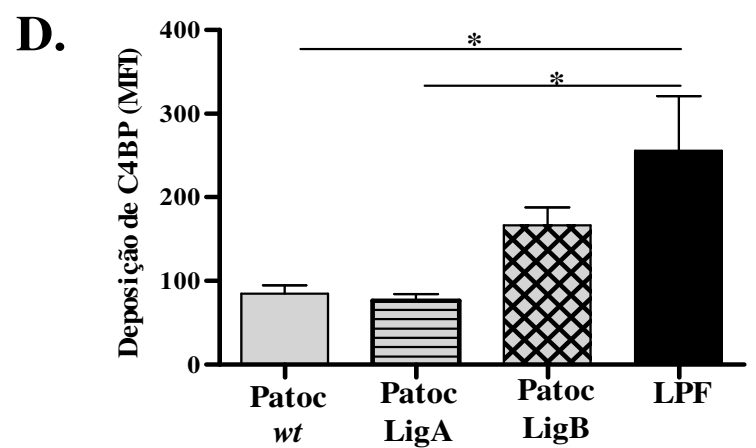

Bactérias de LPF, Patoc LigA, Patoc LigB, Patoc $w t$ (selvagem) $\left(2 \times 10^{8}\right)$ foram incubadas com $10 \%$ de SHN como fonte de FH ou C4BP; os produtos da incubação foram analisados por Western blot. (P) precipitados bacterianos incubados com SHN; (L) alíquota da última lavagem. Bandas correspondentes a FH (150 kDa) e C4BP $\alpha(70 \mathrm{kDa})$ e $\beta(45 \mathrm{kDa})$ foram detectadas com anti-FH policlonal (A) e com anti-C4BP policlonal (B). Experimento representativo de 3 diferentes. Culturas de $2 \times 10^{8}$ bactérias de LPF, Patoc LigA, Patoc LigB, Patoc $w t$ (selvagem) foram incubadas com $20 \%$ de SHN (histograma azul) ou com PBS controle negativo (histograma vermelho) (C). Deposição de C4BP na superfície das bactérias representada pela média da intensidade da fluorescência (MFI), considerando uma média de 3 experimentos diferentes. A significância estatística foi analisada por ANOVA * $(p<0.005)$ (D). Deposição de C4BP na superfície da bactéria foi detectada com antiC4BP na diluição 1:100, posteriormente incubadas com anti-IgG de cabra conjugado com FITC na diluição de 1:200. Após incubação, as bactérias foram analisadas por citometria de fluxo. Experimento representativo de três experimentos realizados. 
4.15 Análise da atividade de FH e C4BP como co-fator de FI na clivagem de C3b e C4b respectivamente em leptospiras transgênicas $L$. biflexa sorovar Patoc expressando $\operatorname{lig} \mathrm{A}$ e $\operatorname{ligB}$

Após confirmação da importância da presença das proteínas Ligs para a sobrevida das leptospiras transgênicas, nós decidimos avaliar se o incremento na sobrevida estaria relacionado com a capacidade destas bactérias de interagir com os reguladores FH e C4BP. Avaliamos a atividade destes reguladores ligados à membrana das leptospiras empregando SHN como fonte de FH e C4BP, ou FH e C4BP purificados. As reações foram analisadas por Western blot. Quando se utilizou tanto as bactérias transgênicas para LigA quanto as transgênicas para LigB, pôde-se observar a presença dos fragmentos de 68 kDa, 46 kDa e 43 kDa gerados pela clivagem enzimática da cadeia $\alpha^{\prime}$ de C3b (Figura 34). Evidente redução da intensidade correspondente à cadeia $\alpha^{\prime}$ de $\mathrm{C} 4 \mathrm{~b}$ e bandas de aproximadamente 64 kDa e 17 $\mathrm{kDa}$ foi observada na clivagem de $\mathrm{C} 4 \mathrm{~b}$, principalmente na presença de SHN como fonte de C4BP. A clivagem das proteínas pôde ser visualizada desde a primeira hora de incubação (Figura 35). Ao avaliar a atividade de co-fator destes dois reguladores observamos que, quando foi empregado soro como fonte de FH (Figura 34) ou C4BP (Figura 35), a atividade de co-fator foi mais eficiente se comparada com a proteína purificada; pois na presença de soro foram observados produtos de clivagem adicionais. Não se observaram bandas de clivagem na ausência de FH, C4BP ou SHN. Isto confirma que os fragmentos de clivagem são produtos da atividade dos reguladores ligados às leptospiras transgênicas e não são resultantes da ação de proteases bacterianas.

Em resumo, estes resultados indicam que as leptospiras transgênicas para LigA e LigB são capazes de se ligar aos reguladores do complemento FH e C4BP e estes mantêm a atividade de cofatores do FI para a clivagem das proteínas $\mathrm{C} 3 \mathrm{~b}$ e $\mathrm{C} 4 \mathrm{~b}$ respectivamente. 
Figura 34 - Análise da atividade de FH como co-fator de FI na clivagem de C3b

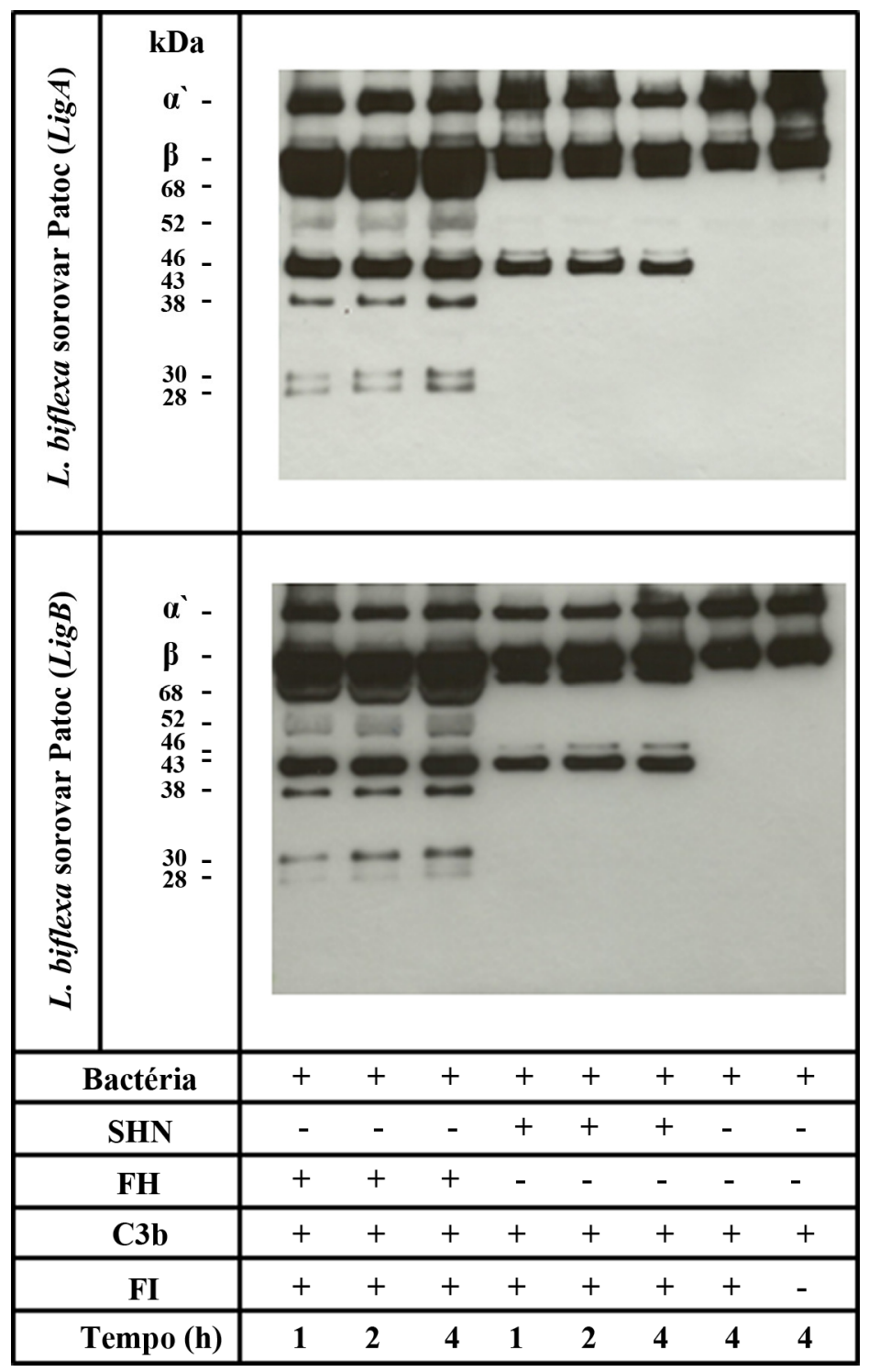

Culturas de L. biflexa sorovar Patoc transgênica para LigA ou LigB $\left(2 \times 10^{8}\right)$ foram incubadas com $5 \%$ de SHN como fonte de FH, com FH purificado $(2 \mu \mathrm{g})$ ou com PBS. Após lavagem, C3b (500 ng) e FI (250 ng) foram adicionados. A reação foi incubada por $1,2 \mathrm{e} 4 \mathrm{~h}$ a $37{ }^{\circ} \mathrm{C}$. Os produtos foram analisados por SDS-PAGE $12 \%$ e os fragmentos de clivagem de $\mathrm{C} 3 \mathrm{~b}$ foram detectados por Western blot com anti-C3 policlonal. As bactérias foram capazes de se ligar ao $\mathrm{FH}$ o qual reteve sua atividade de co-fator na clivagem de $\mathrm{C} 3 \mathrm{~b}$, produzindo fragmentos de $68 \mathrm{kDa}, 52 \mathrm{kDa}, 46 \mathrm{kDa}, 43 \mathrm{kDa}, 38 \mathrm{kDa}, 30 \mathrm{kDa}$ e $28 \mathrm{kDa}$. 
Figura 35 - Análise da atividade de C4BP como co-fator de FI na clivagem de C4b

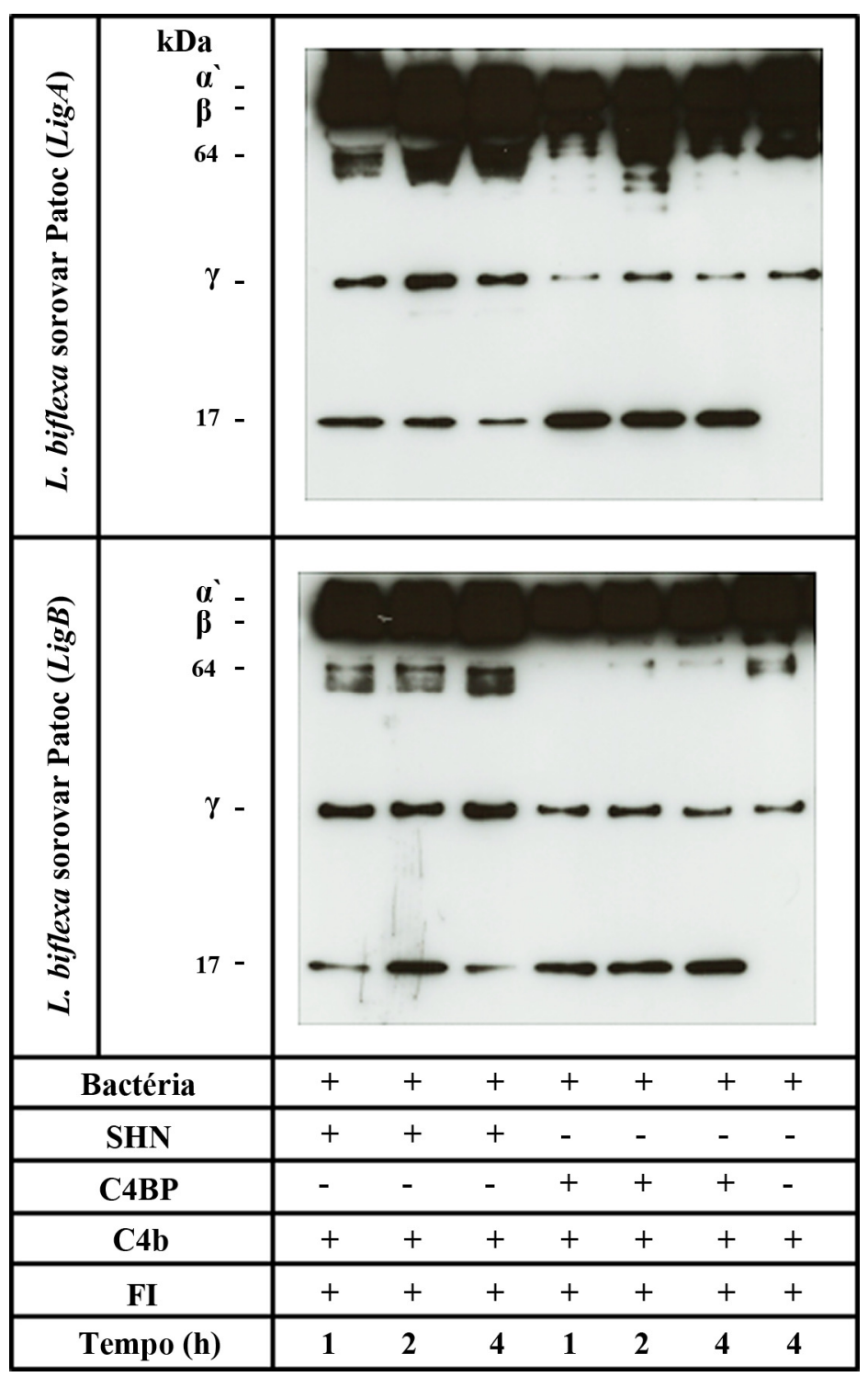

Culturas de L. biflexa sorovar Patoc transgênica para LigA ou LigB $\left(2 \times 10^{8}\right)$ foram incubadas com 5\% de SHN como fonte de C4BP, com C4BP purificado $(2 \mu \mathrm{g})$ ou com PBS. Após lavagem, C4b (500 ng) e FI (250 ng) foram adicionados. A reação foi incubada por 1,2 e $4 \mathrm{~h}$ a $37{ }^{\circ} \mathrm{C}$. Os produtos foram analisados por SDS-PAGE $12 \%$ e os fragmentos de clivagem de $\mathrm{C} 4 \mathrm{~b}$ foram detectados por Western blot com anti- C4 policlonal. As bactérias foram capazes de se ligar C4BP o qual reteve sua atividade de co-fator na clivagem de $\mathrm{C} 4 \mathrm{~b}$, produzindo fragmentos de 64 e $17 \mathrm{kDa}$. 
4.16 Avaliação da interação de C3, C4 e MAC com as leptospiras transgênicas L. biflexa sorovar Patoc expressando ligA e ligB

Análises por citometria de fluxo demonstraram que culturas de L. biflexa sorovar Patoc transgênica para LigA ou LigB depositaram menos C3 ou fragmentos de C3 (Figura 36) e MAC (Figura 38) que a cepa L. biflexa sorovar Patoc, indicando que provavelmente a presença das proteínas LigA e LigB na superfície da bactéria contribuem para a regulação da deposição destas proteínas.

Tanto a leptospira L. biflexa quanto as leptospiras transgênicas expressando ligA e ligB depositam C4 ou fragmentos de Cade maneira similar e somente a L. interrogans consegue reduzir significativamente deposição de C4 (Figura 37). A deposição do MAC foi maior em L. biflexa, quando comparada como observado com as transgênicas e a L. interrogans. Porém, a deposição de MAC foi menor em L. interrogans que nas demais bactérias sugerindo que as leptospiras patogênicas conseguem regular melhor a deposição do MAC (Figura 38).

Os experimentos também sugerem que a deposição do MAC está diretamente relacionada com a deposição de $\mathrm{C} 3$, pois quanto maior a deposição desta proteína nas diferentes bactérias, maior será a formação de MAC (Figuras 36 e 38). Estes dados sugerem que o controle da deposição de $\mathrm{C} 3 \mathrm{~b}$ na bactéria é provavelmente dependente da regulação exercida pelo FH e C4BP em sua superfície, constituindo assim, um mecanismo protetor importante para a sobrevida bacteriana na presença do soro. 
Figura 36 - Análise por citometria de fluxo da deposição de C3 em Leptospira
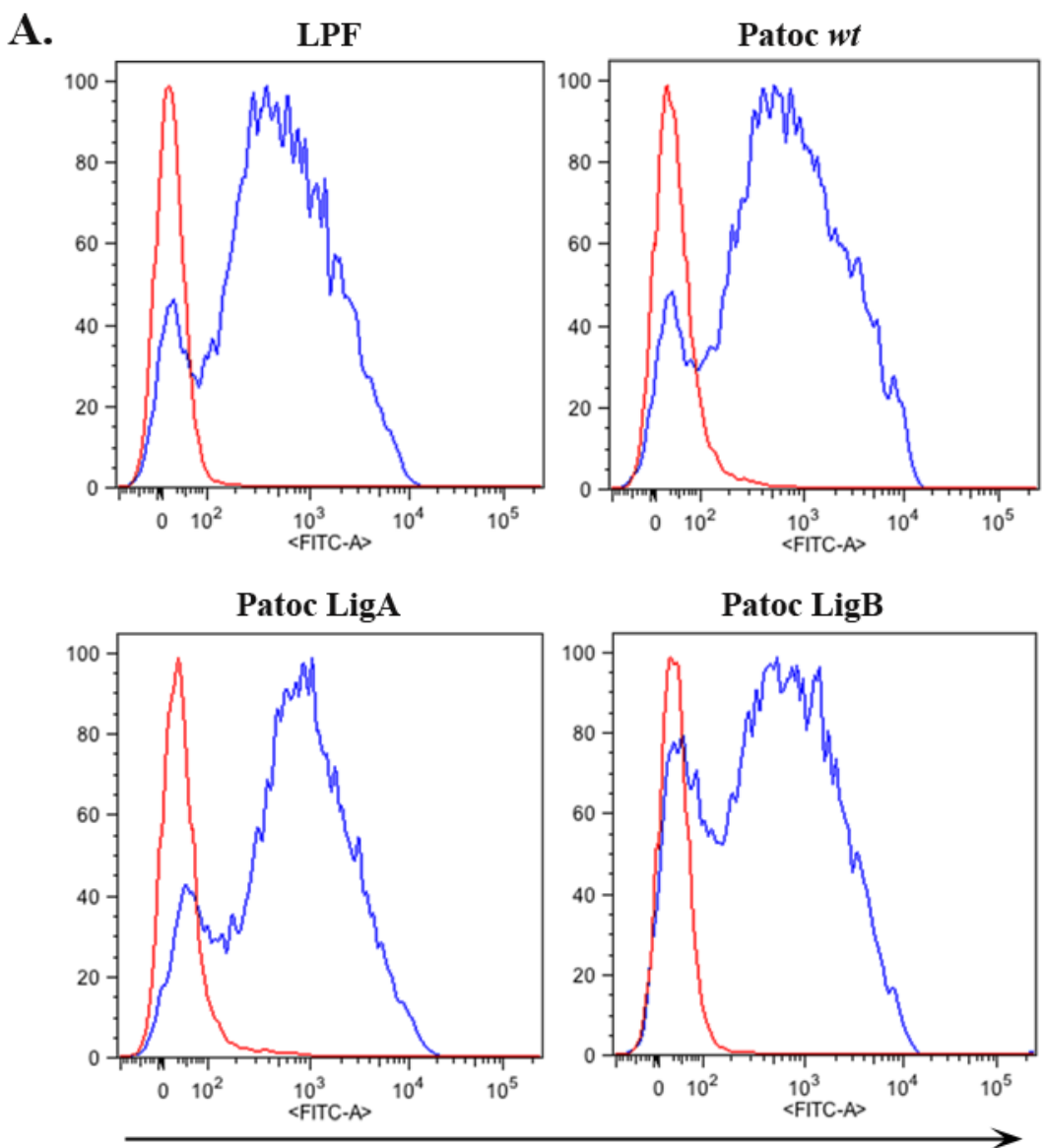

Deposição de C3

B.

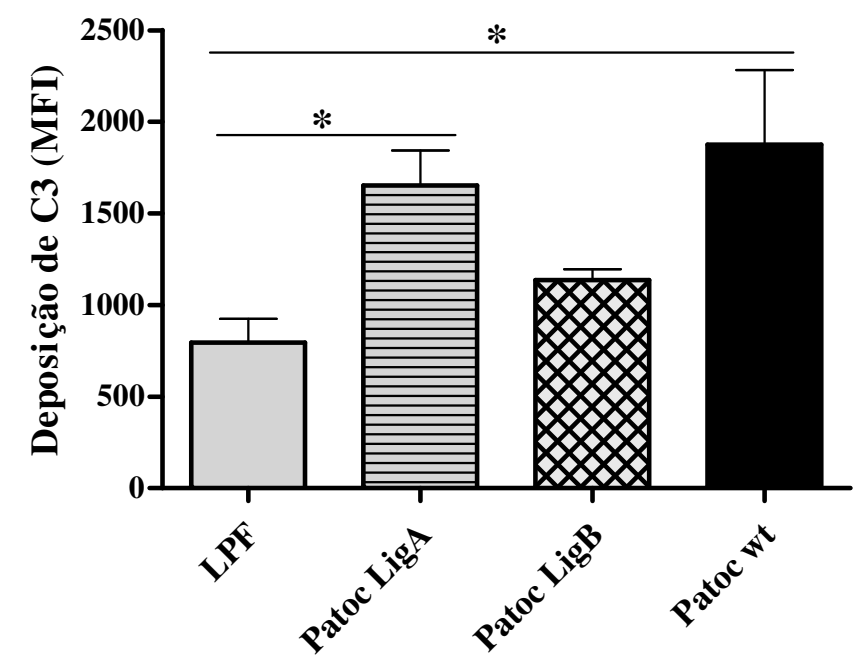

Culturas de $2 \times 10^{8}$ bactérias de LPF, Patoc LigA, Patoc LigB, Patoc $w t$ (Selvagem) foram incubadas com $20 \%$ de SHN (histograma azul) ou com PBS controle negativo (histograma vermelho). Deposição de fragmentos de C3 na superfície da bactéria foram detectados com anti-C3 na diluição 1:100 e anti-IgG de cabra conjugado com FITC na diluição de 1:200. Após incubação, as bactérias foram analisadas por citometria de fluxo. Experimento representativo de três realizados (A). Deposição de fragmentos de C3 na superfície das bactérias representada pela média da intensidade de fluorescência (MFI), considerando uma média de 3 experimentos diferentes. A significância estatística foi analisada pelo teste ANOVA $*(p<0.005)(\mathbf{B})$. 
Figura 37 - Análise por citometria de fluxo da deposição da C4 em Leptospira

A.
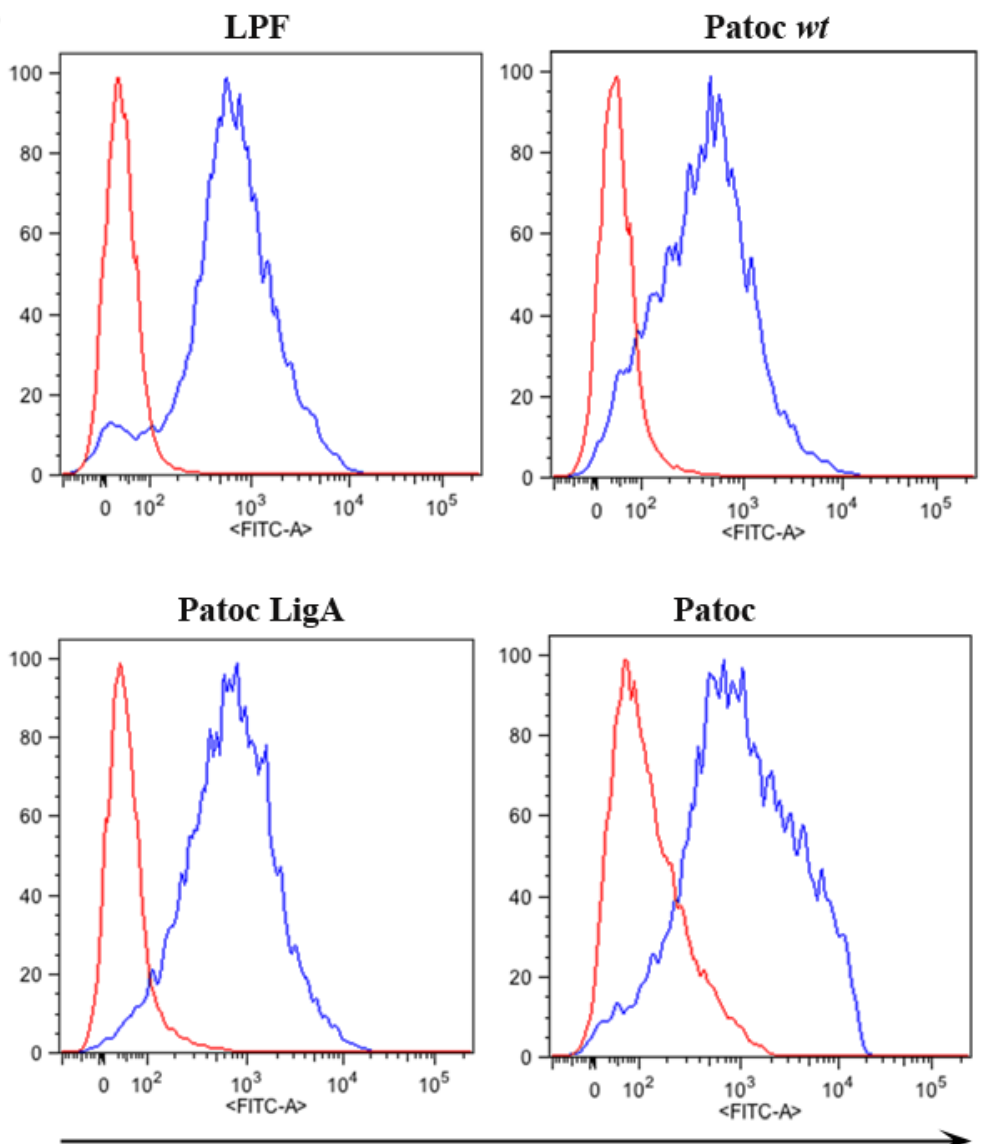

Deposição de C4

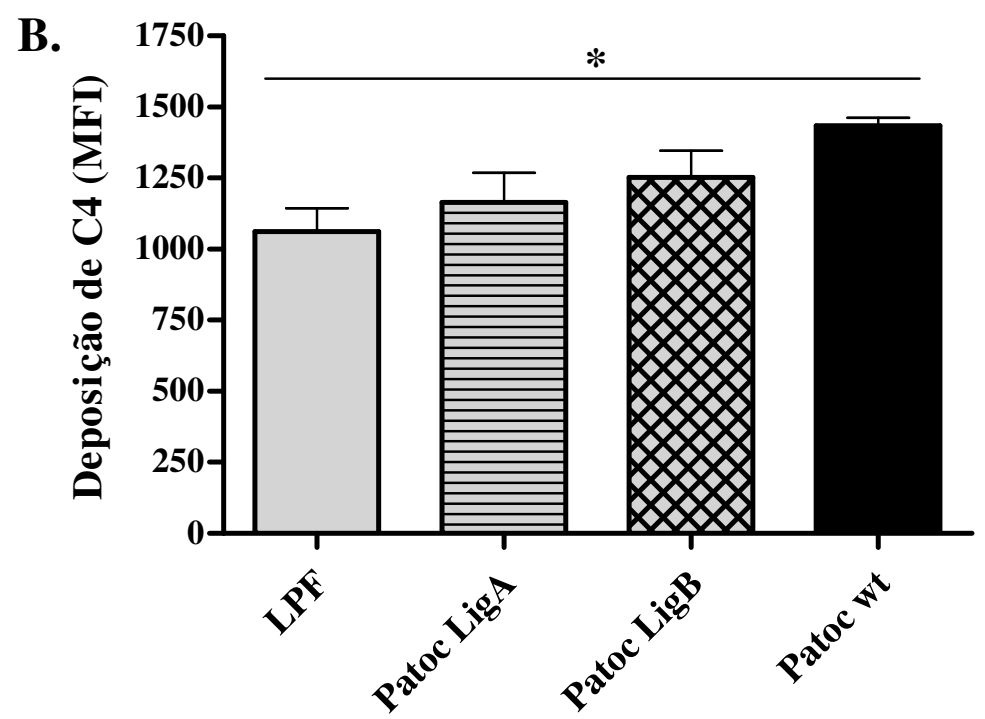

Culturas de $2 \times 10^{8}$ bactérias de LPF, Patoc LigA, Patoc LigB, Patoc $w t$ (selvagem) foram incubadas com $20 \%$ de SHN (histograma azul) ou com PBS controle negativo (histograma vermelho). Deposição de fragmentos de C4 na superfície da bactéria foram detectados com anti-C4 na diluição 1:100 e anti-IgG de cabra conjugado com FITC na diluição de 1:200. Após incubação, as bactérias foram analisadas por citometria de fluxo. Experimento representativo de três realizados (A). Deposição de fragmentos C4 na superfície das bactérias representada pela média da intensidade de fluorescência (MFI), considerando uma média de 3 experimentos diferentes. A significância estatística foi analisada por ANOVA $*(p<0.005)(\mathbf{B})$. 
Figura 38 - Análise por citometria de fluxo da deposição de MAC em Leptospira

A.

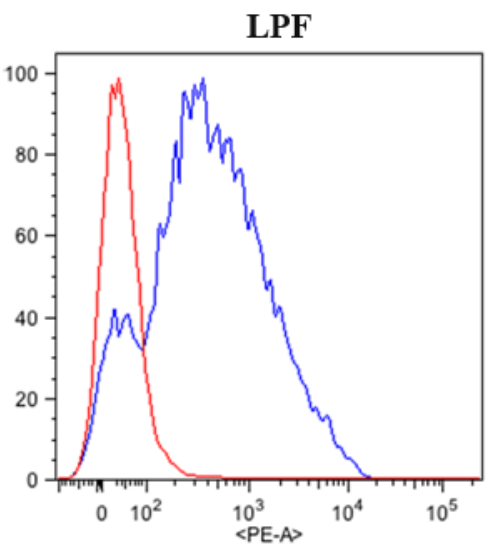

Patoc LigA

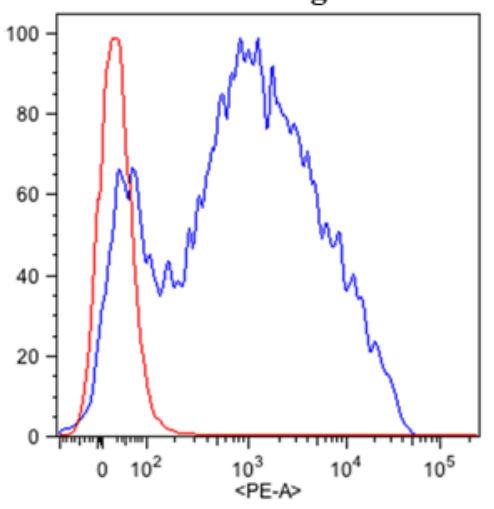

Patoc $w t$

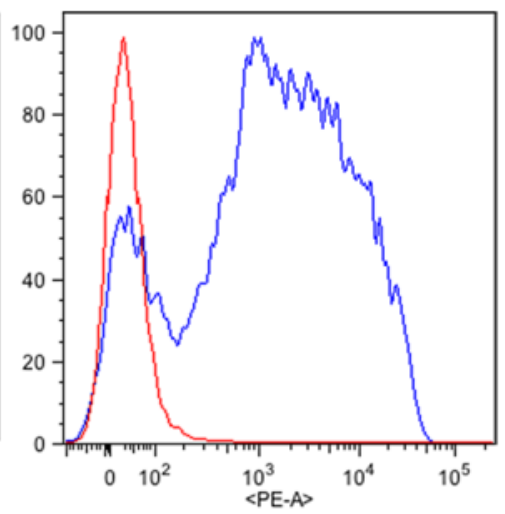

Patoc LigB

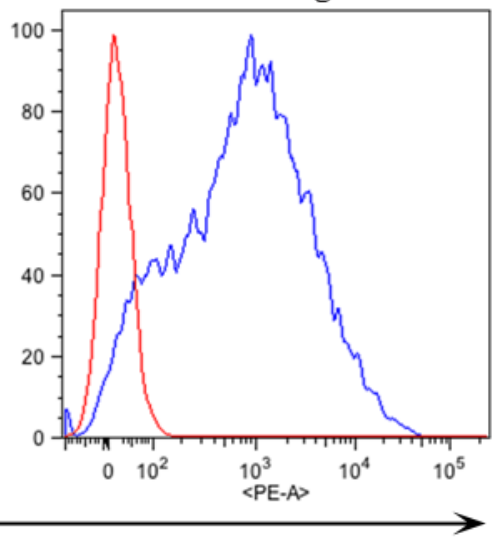

Deposição de MAC

B.

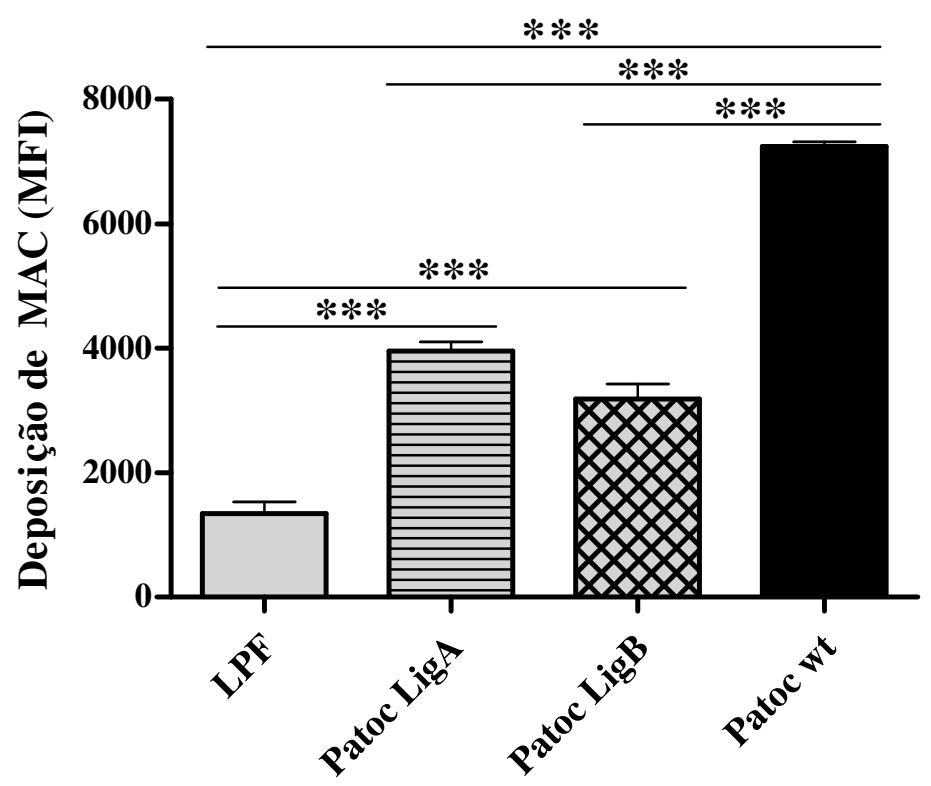

Culturas de $2 \times 10^{8}$ bactérias de LPF, Patoc LigA, Patoc LigB, Patoc $w t$ (selvagen) foram incubadas com $20 \%$ de SHN (histograma azul) ou com PBS controle negativo (histograma vermelho). Deposição de MAC na superfície da bactéria foram detectados com anti-MAC na diluição 1:100 e anti-IgG de cabra conjugado com PE na diluição de 1:200. Após incubação, as bactérias foram analisadas por citometria de fluxo. Experimento representativo de três realizados (A). Deposição de MAC na superfície das bactérias representada pela média da intensidade da fluorescência (MFI), considerando uma média de 3 experimentos diferentes. A significância estatística foi analisada por ANOVA * $(p<0.005)(\mathbf{B})$. 
4.17 Interação das proteínas Lig com plasminogênio

A aquisição de plasminogênio por diversos patógenos tem sido descrita por vários autores. Este precursor inativo é convertido proteoliticamente em plasmina, causando degradação de fibrina e promovendo, por exemplo, a invasão tecidual (Rossmann et al., 2007). Muitos dos ligantes de plasminogênio também apresentam interação com outras moléculas do hospedeiro, o que os converte em formidáveis fatores de virulência, importantes em processos de invasão e evasão (Coleman et al., 1997; Fuchs et al., 1994; Klempner et al., 1996; Rossmann et al., 2007). Como já era conhecido que as proteínas Ligs interagem com muitas moléculas do hospedeiro, decidimos avaliar a possibilidade de interação destas com plasminogênio.

As proteínas LigAC, LigBC, e LigBN interagiram com plasminogênio purificado, quando analisadas por Western blot (Figura 39). Como controle positivo e negativo de ligação foram usadas as proteínas de membrana de L. interrogans LipL32 (Vieira et al., 2010) e LIC10301, respectivamente.

Figura 39 - Análise da interação das proteínas recombinantes de L. interrogans com plasminogênio por Western blot com sobreposição

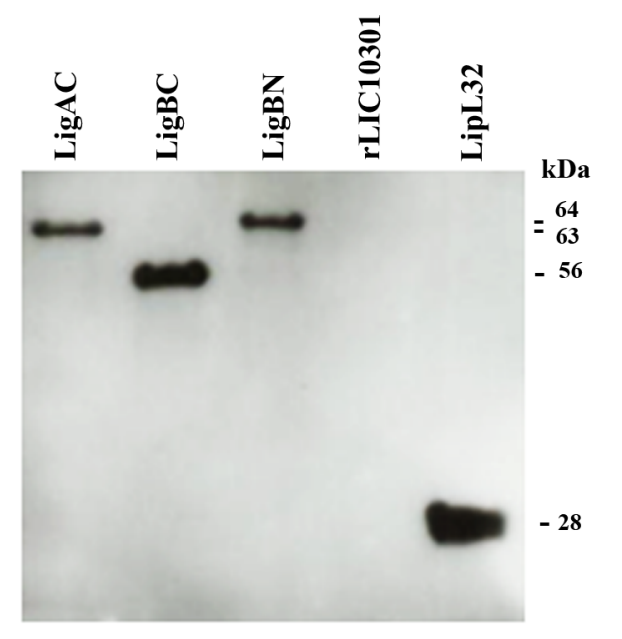

As proteínas recombinantes bacterianas LigAC, LigBC, LigBN, rLIC10301, e LipL32 foram submetidas a SDSPAGE $12 \%$ em condições não redutoras e transferidas para membrana de nitrocelulose. A membrana foi incubada com plasminogênio purificado $(10 \mu \mathrm{g} / \mathrm{ml})$ e a interação foi detectada com anti-plasminogênio policlonal. As proteínas LigAC, LigBC e LigBN interagiram com plasminogênio. A proteína LIC10301 foi usada como controle negativo de ligação. LipL32 foi usada como controle positivo.

As proteínas LigBC e LigBN também interagiram com plasminogênio, quantificado por ELISA. No entanto, esta interação não foi observada para a porção C-terminal da proteína 
LigA. É possível que sítios importantes de ligação não fiquem expostos na placa, impedindo a interação entre essas duas proteínas (Figura 40).

Figura 40 - Análise da interação de plasminogênio com as proteínas Lig por ELISA

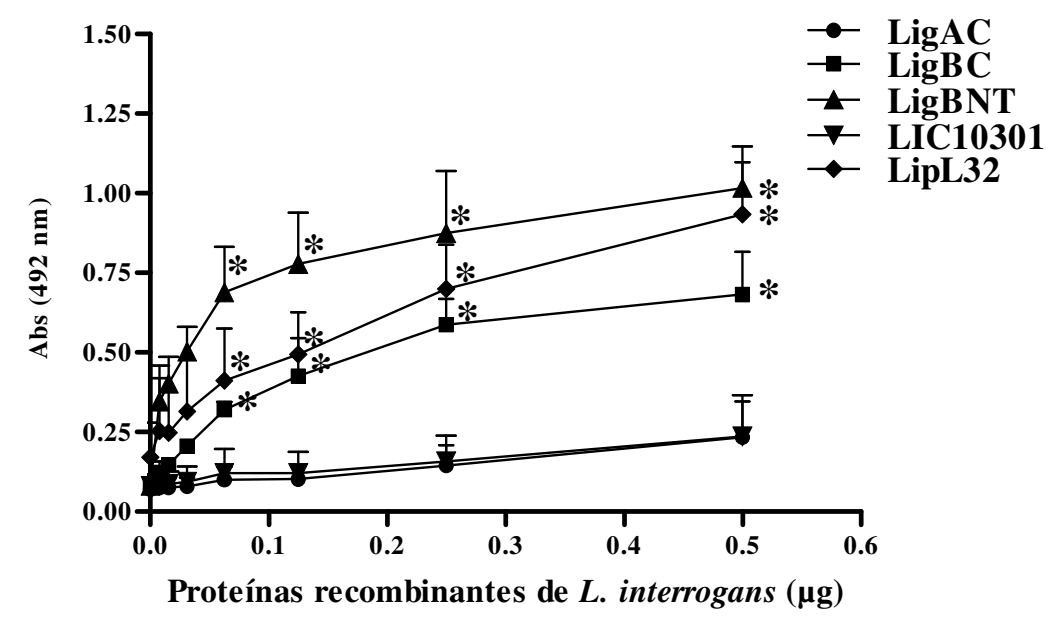

Plasminogênio foi imobilizado na placa e incubado com as proteínas recombinantes bacterianas LigAC, LigBC, LigBN, LIC10301, LipL32. Todas as proteínas bacterianas foram detectadas com anticorpos específicos. LIC10301 foi usada com controle negativo e LipL32 como controle positivo. Cada ponto representa uma media do valor de absorbância a $492 \mathrm{~nm}$ de 3 experimentos diferentes. A ligação de PLG às proteínas recombinantes foi comparada com a ligação destas moléculas a LIC10301. A análise estatística foi feita empregando-se o test $t$ de Student. * $(p<0.005)$.

4.18 Análise da interação entre plasminogênio e as proteínas Lig na presença diferentes concentrações de $\mathrm{NaCl}$ e ácido aminocapróico (ACA)

Para determinar se a interação entre as proteínas recombinantes LigAC, LigBC e LigBN de L. interrogans e plasminogênio é dependente de forças iônicas, as proteínas Lig foram incubadas na presença de diferentes concentrações de $\mathrm{NaCl}(50 \mathrm{mM}, 100 \mathrm{mM}, 200 \mathrm{mM}$ e $400 \mathrm{mM})$. Em condições fisiológicas a osmolaridade sanguínea corresponde a aproximadamente $300 \mathrm{mOsm} / \mathrm{L}$ e a concentração $\mathrm{NaCl}$ nestas condições é de $150 \mathrm{mM}$. Mas, em processos infecciosos estas concentrações podem variar devido ao desequilíbrio eletrolítico produzido principalmente por lesões no rim e de desidratação. Nestes experimentos observamos que a interação das proteínas recombinantes Lig com plasminogênio foi significativamente diminuída para $50 \%$ na presença de $200 \mathrm{mM}$ de $\mathrm{NaCl}$ (Figura 41).

Já é conhecido que os domínios kringle do plasminogênio são importantes no processo fibrinolítico para a interação desta molécula com a fibrina. No entanto, ultimamente 
foi mostrado que esses domínios frequentemente mediam interações com resíduos de lisina de diferentes receptores bacterianos. A interação de plasminogênio com L. interrogans sorovar Copenhageni é inibida na presença de ACA, um análogo dos resíduos de lisina (Vieira et al., 2010). Uma vez que ACA inibe totalmente a interação entre plasminogênio e L. interrogans, decidimos analisar se ACA também poderia inibir a interação entre plasminogênio e as proteínas Ligs.

Os resultados mostraram que a interação de plasminogênio com as proteínas Ligs é dependente de resíduos de lisina, uma vez que concentrações superiores a 0,5 mM de ACA inibem a interação entre estas proteínas (Figura 42).

Figura 41 - Interferência de forças iônicas na interação de plasminogênio com as proteínas Lig
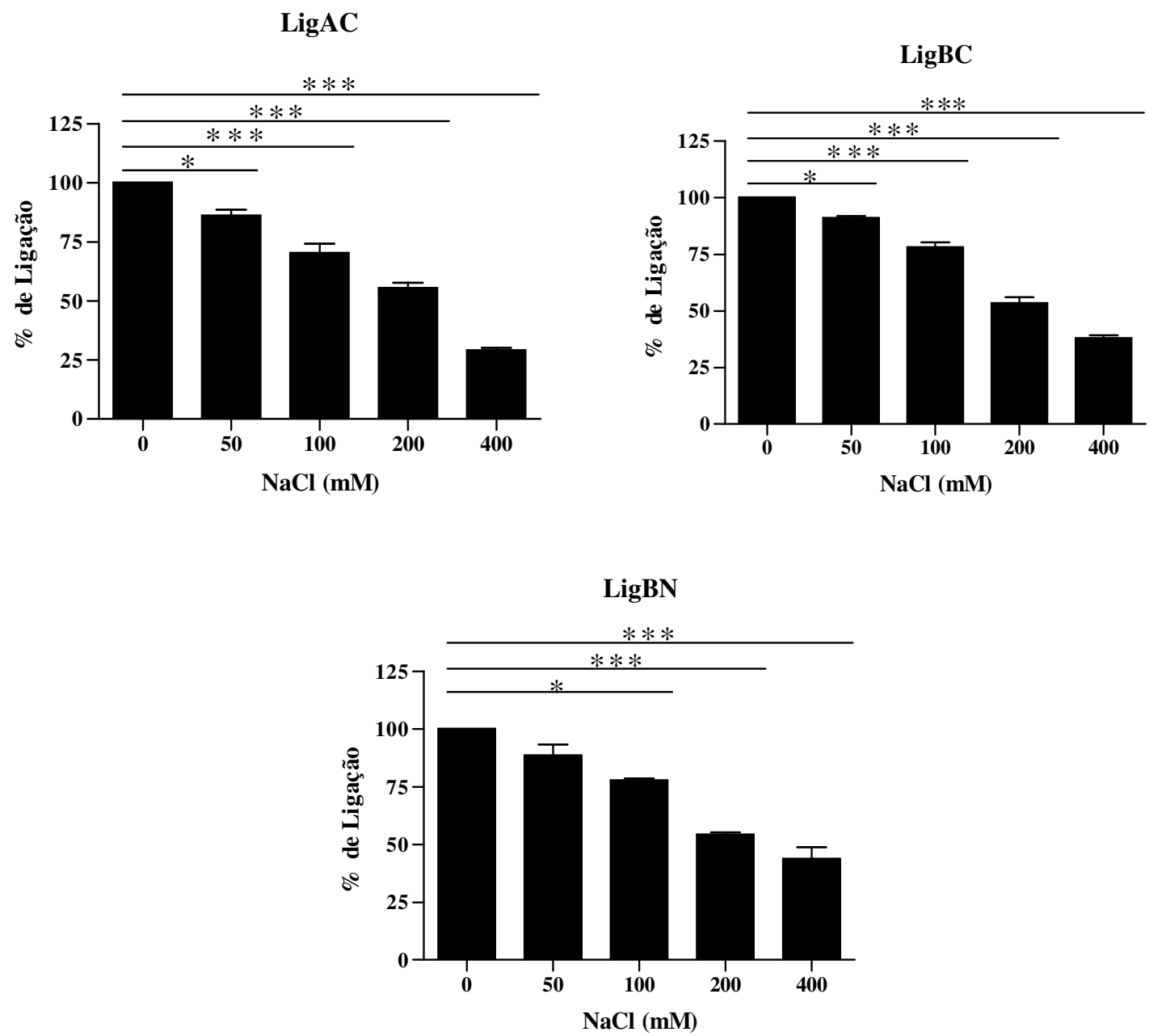

Proteínas recombinantes LigAC, LigBC e LigBN foram incubadas com PLG na presença de diferentes concentrações de $\mathrm{NaCl}(50-400 \mathrm{mM})$. A interação entre PLG e as proteínas Lig foi detectada com anticorpo policlonal anti-PLG (específico para o domínio kringle 5). Estes dados representam uma media de 3 experimentos diferentes realizados em duplicata. A significância estatística foi analisada por ANOVA, * $(p<0.005)$ 
Figura 42 - Caracterização do papel dos resíduos de lisina na interação de plasminogênio com as proteínas Lig
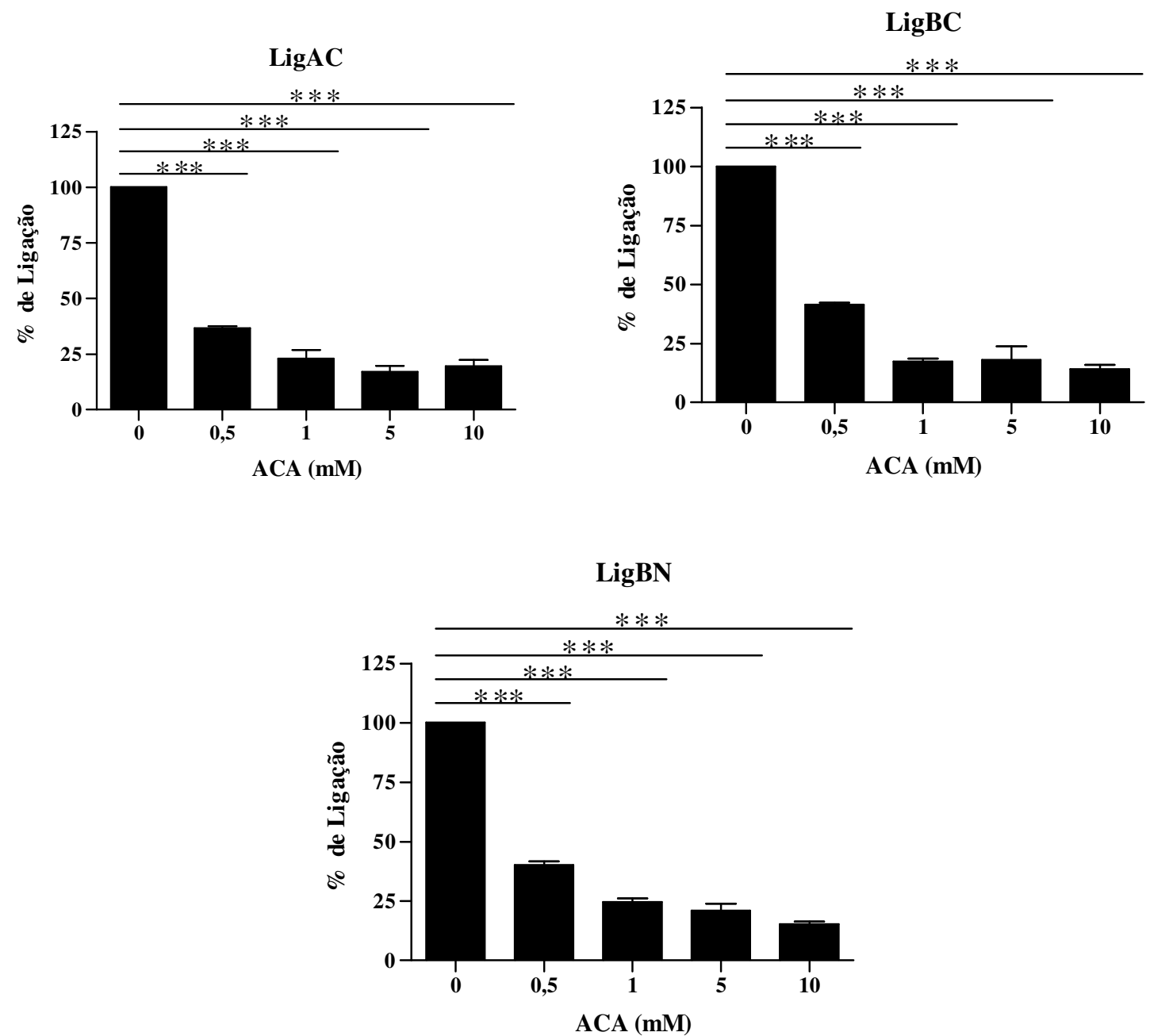

Proteínas recombinantes LigAC, LigBC e LigBN foram incubadas com PLG em diferentes concentrações de ACA $(0,5,1,5$ e $10 \mathrm{mM})$. A interação entre PLG e as proteínas Lig foi detectada com anticorpo policlonal antiPLG (específico para o domínio kringle 5). Estes resultados representam uma media de 3 experimentos diferentes realizados em duplicata. A significância estatística foi analisada por ANOVA, * $(p<0.05)$.

4.19 Plasminogênio ligado às proteínas Ligs é convertido em plasmina

Com o objetivo de avaliar se o plasminogênio ligado às proteínas recombinantes de Leptospira interrogans ( $\operatorname{LigAC}, \operatorname{LigBC}, \operatorname{LigBN}$ ) poderia ser convertido em plasmina, as proteínas Lig foram incubadas com plasminogênio. O plasminogênio que não ligou às proteínas Lig foi removido por sucessivas lavagens. Em seguida, foram adicionados o ativador de plasminogênio uPA e o substrato cromogênico específico para plasmina. Esta reação foi incubada por $24 \mathrm{~h}$, e atividade da plasmina gerada foi medida pela clivagem do substrato utilizando-se absorbância de 405 nm (Figuras 43). Como observado, o 
plasminogênio ligado às proteínas Ligs pôde ser convertido em plasmina, demonstrado indiretamente pela atividade proteolítica específica sobre o substrato. O controle negativo BSA, que não se liga ao plasminogênio, não apresentou atividade proteolítica, assim como os controles que carecem de plasminogênio ou uPA. PAI-1 é inibidor do uPA e as reações contendo este inibidor não apresentaram atividade proteolítica. As proteínas LipL32 e LIC10301 também foram usadas, respectivamente como controles positivo e negativo de ligação ao plasminogênio.

Figura 43 - Atividade da plasmina gerada na presença de proteínas recombinantes de $L$. interrogans

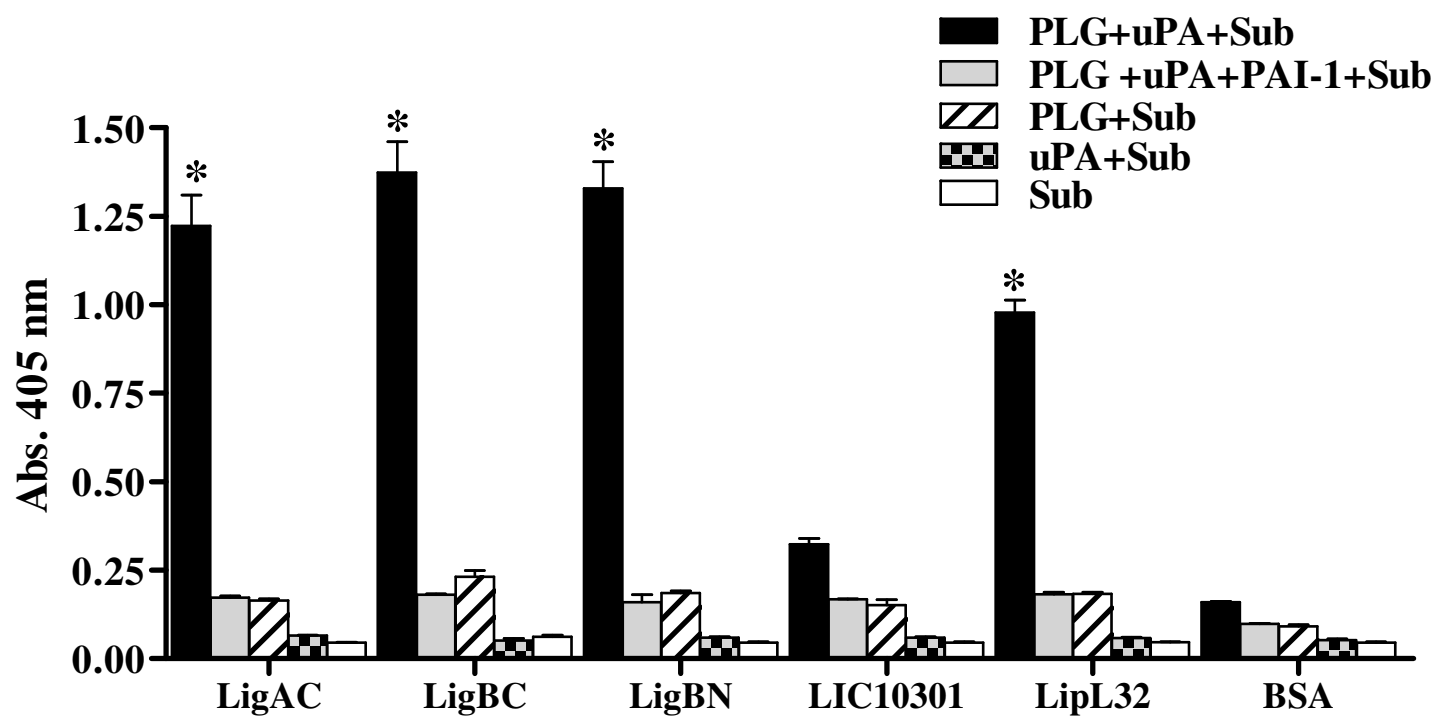

As proteínas recombinantes LigAC, LigBC, LigBN e LipL32 ou BSA (10 $\mu \mathrm{g} / \mathrm{ml})$, foram incubadas com 20 $\mu \mathrm{g} / \mathrm{ml}$ de PLG. Após lavagens, uPA (3 U) e o substrato cromogênico específico para plasmina foram adicionados. Estes resultados representam uma media do valor da absorbância a $405 \mathrm{~nm}$ de 3 experimentos diferentes realizados em duplicata. A significância estatística foi analisada por ANOVA, * $(p<0.05)$.

4.20 Plasmina gerada sobre as proteínas Lig cliva fibrinogênio e as proteínas C3b e C5 do sistema complemento

O plasminogênio ligado às proteínas é convertido em plasmina quando incubado com o ativador uPA. Como a plasmina tem atividade de serino protease, decidimos avaliar se ela seria capaz de clivar seu substrato específico fibrinogênio e as moléculas C3b e C5 do sistema complemento. A ação da plasmina sobre essas proteínas foi acompanhada por 1, 4 e $16 \mathrm{~h}$. A plasmina foi capaz de clivar a cadeia $\alpha$ do fibrinogênio em fragmentos de $63 \mathrm{kDa}$ e $60 \mathrm{kDa}$. A 
clivagem da cadeia $\alpha$ foi tempo dependente, como demonstrado pelo desaparecimento da banda referente a esta cadeia conforme transcorreu o tempo de incubação (Figura 44).

Figura 44 - Clivagem do fibrinogênio pela plasmina gerada após ligação do plasminogênio às proteínas recombinantes de L. interrogans

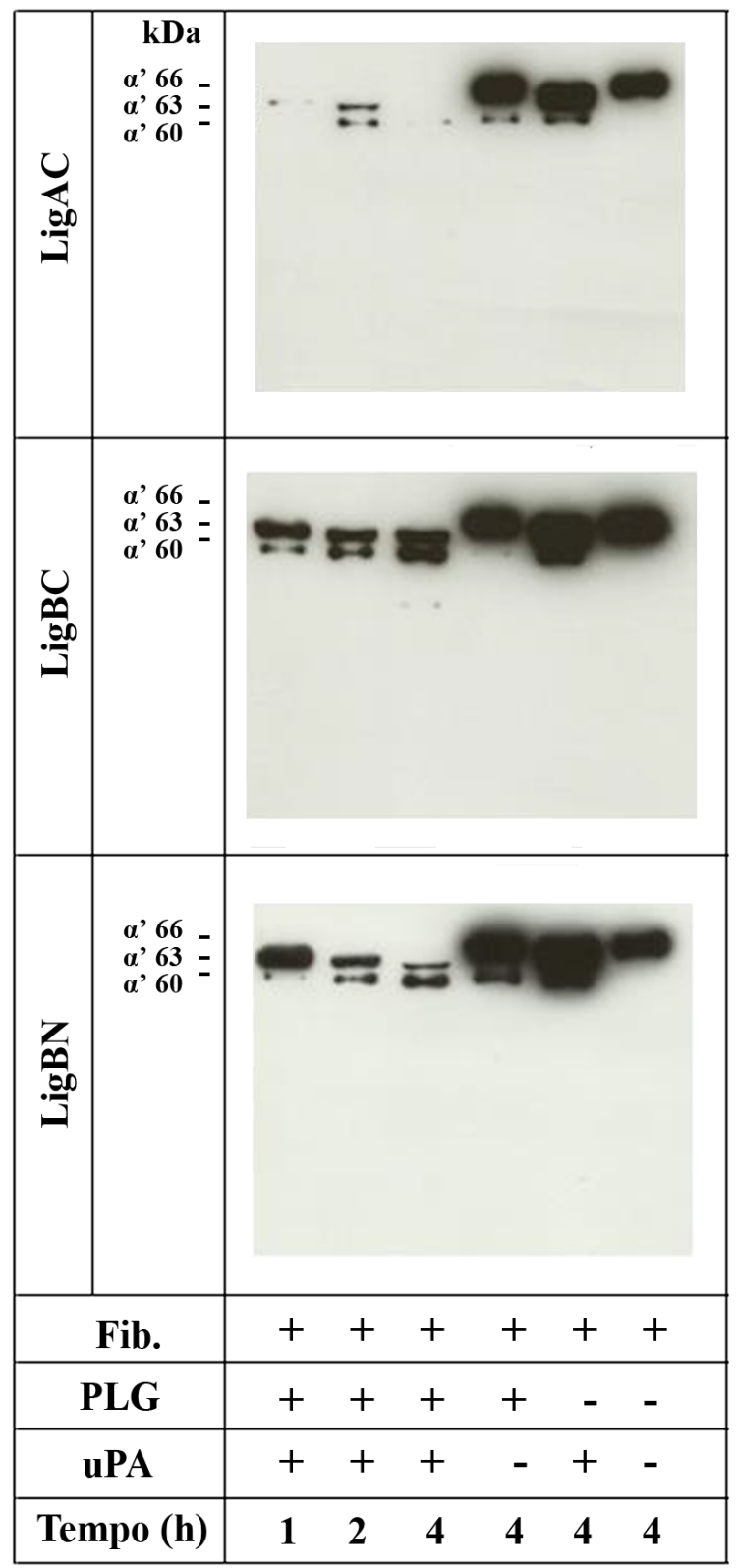

Proteínas recombinantes de $L$. interrogans $\operatorname{LigAC}$, LigBC, $\operatorname{LigBN}(10 \mu \mathrm{g} / \mathrm{ml})$ foram incubadas com plasminogênio (PLG, $20 \mu \mathrm{g} / \mathrm{ml}$ ). Após lavagens, fibrinogênio (500 ng) e uPA (3 U) foram adicionados e incubados nos três tempos indicados. Os produtos da incubação foram separados por SDS-PAGE, transferidos para membranas de nitrocelulose e detectados com anticorpo monoclonal anti- fibrinogênio feito em camundongo (reconhece especificamente a cadeia $\alpha$ de fibrinogênio) seguido por incubação com anti-IgG de camundongo conjugado com peroxidase. Como controles das clivagens foram omitidos uPA ou PLG na incubação. Experimento representativo de 3 experimentos independentes. 
No que diz respeito às proteínas do complemento, $\mathrm{C} 3 \mathrm{~b}$ foi clivado em fragmentos de $68 \mathrm{kDa}, 46 \mathrm{kDa}, 40 \mathrm{kDa}, 30 \mathrm{kDa}$ e $17 \mathrm{kDa}($ Figura 45) e a proteína C5 em fragmentos de 67 kDa, 41 kDa, 30 kDa e 28 kDa (Figura 46).

Observamos que a clivagem de C3b foi mais pronunciada após incubação por $16 \mathrm{~h}$, quando comparada com 4h (Figura 45). Uma fraca degradação da molécula de C3b foi obtida com $4 \mathrm{~h}$ de incubação na ausência do ativador uPA com quase todas as proteínas recombinantes testadas, mas nenhuma destas clivagens foi significativa. Também é possível observar um pouco de degradação quando o controle negativo LIC10301 foi incubado por $4 \mathrm{~h}$ e 16 h. Também atribuímos este fato à possibilidade da molécula de C3b degradar parcialmente durante longos períodos de incubação (Figura 45).

Os resultados com a proteína C5 mostram que a cadeia $\alpha$ foi quase totalmente degradada após 16 h de incubação (Figura 46), indicando forte efeito da plasmina sobre esta proteína. Também detectamos uma banda de clivagem de $67 \mathrm{kDa}$ produzida pelo ativador uPA na ausência de plasminogênio. Embora seja uma clivagem muito fraca, esta mesma banda já tinha sido observada em um estudo recente que apresenta o plasminogênio como um inibidor do sistema complemento (Barthel et al., 2012). Embora tenhamos observado bandas oriundas de degradação na maioria dos controles negativos, vale notar que uma degradação substancial e tempo-dependente da cadeia $\alpha$ de C5 só foi observada na presença de LigAC, LigBC e LigBN. Quanto ao controle negativo (proteína LIC10301), não se observou degradação da cadeia $\alpha$ de C5.

As proteínas C3b e C5 são moléculas chave na ativação das três vias do sistema complemento, contudo, quando clivadas pela plasmina nos diferentes fragmentos, a formação das C3 e C5 convertases fica comprometida, e como consequência não há continuação de todas as vias do sistema complemento. Desta maneira, podemos sugerir que as leptospiras patogênicas se ligam ao plasminogênio como mecanismo de evasão da ação do sistema complemento. 
Figura 45 - Clivagem do fragmento C3b do complemento humano pela plasmina gerada após ligação do plasminogênio a proteínas recombinantes de L. interrogans

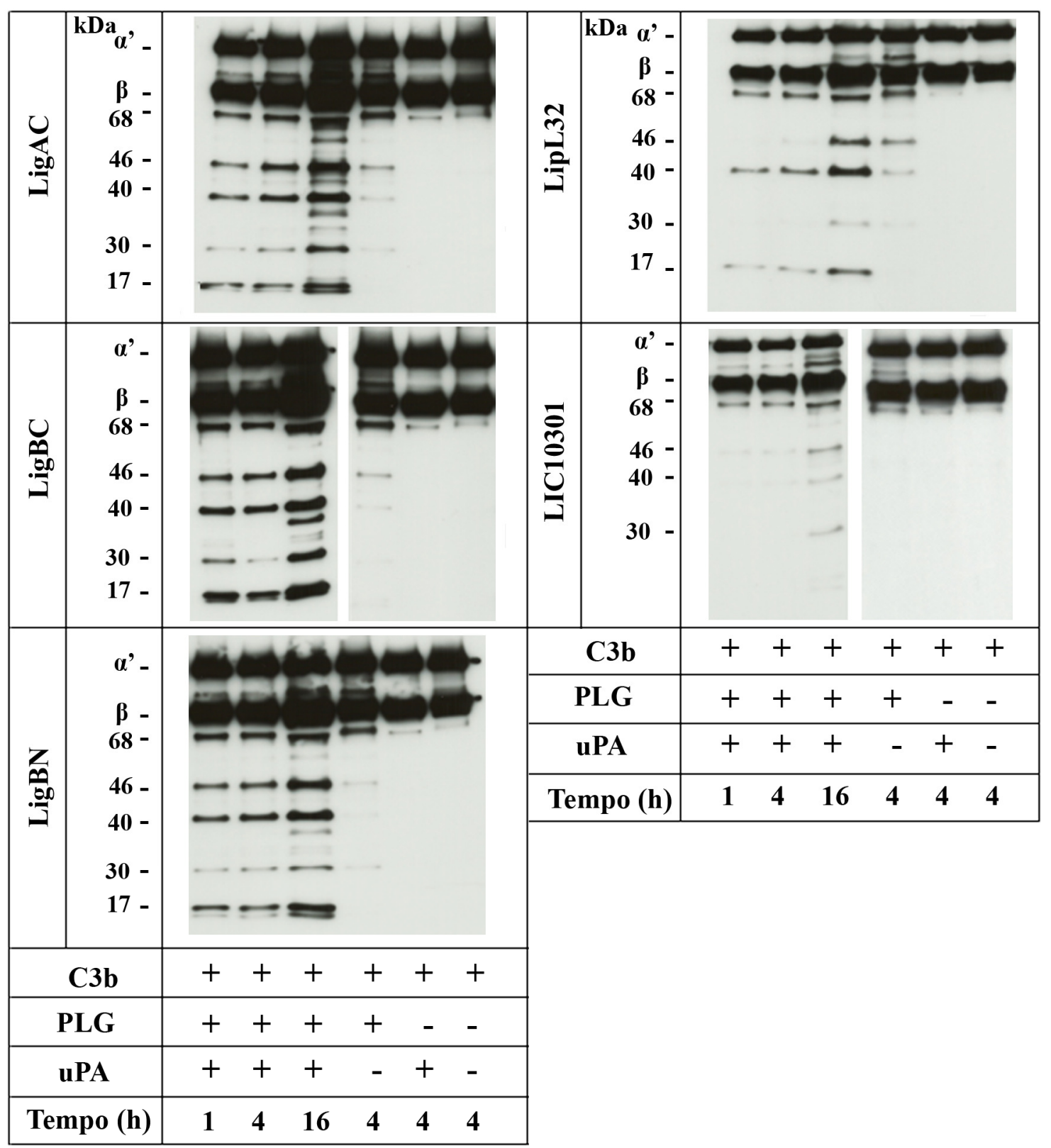

Proteínas recombinantes de L. interrogans LigAC, LigBC, LigBN, LipL32 ou LIC10301 (10 $\mu \mathrm{g} / \mathrm{ml})$ foram incubadas com plasminogênio (PLG, $20 \mu \mathrm{g} / \mathrm{ml}$ ). Após lavagens, C3b (500 ng) e uPA (3 U) foram adicionados e incubados nos três tempos indicados. Os produtos da incubação foram separados por SDS-PAGE, transferidos para membranas de nitrocelulose e detectados com anti- C3 policlonal feito em cabra seguido por incubação com anti-IgG de cabra conjugado com peroxidase. Como controles das clivagens foram omitidos uPA ou PLG na incubação. Experimento representativo de 3 experimentos independentes. 
Figura 46 - Clivagem da proteína C5 do complemento humano pela plasmina gerada após ligação do plasminogênio às proteínas recombinantes de L. interrogans

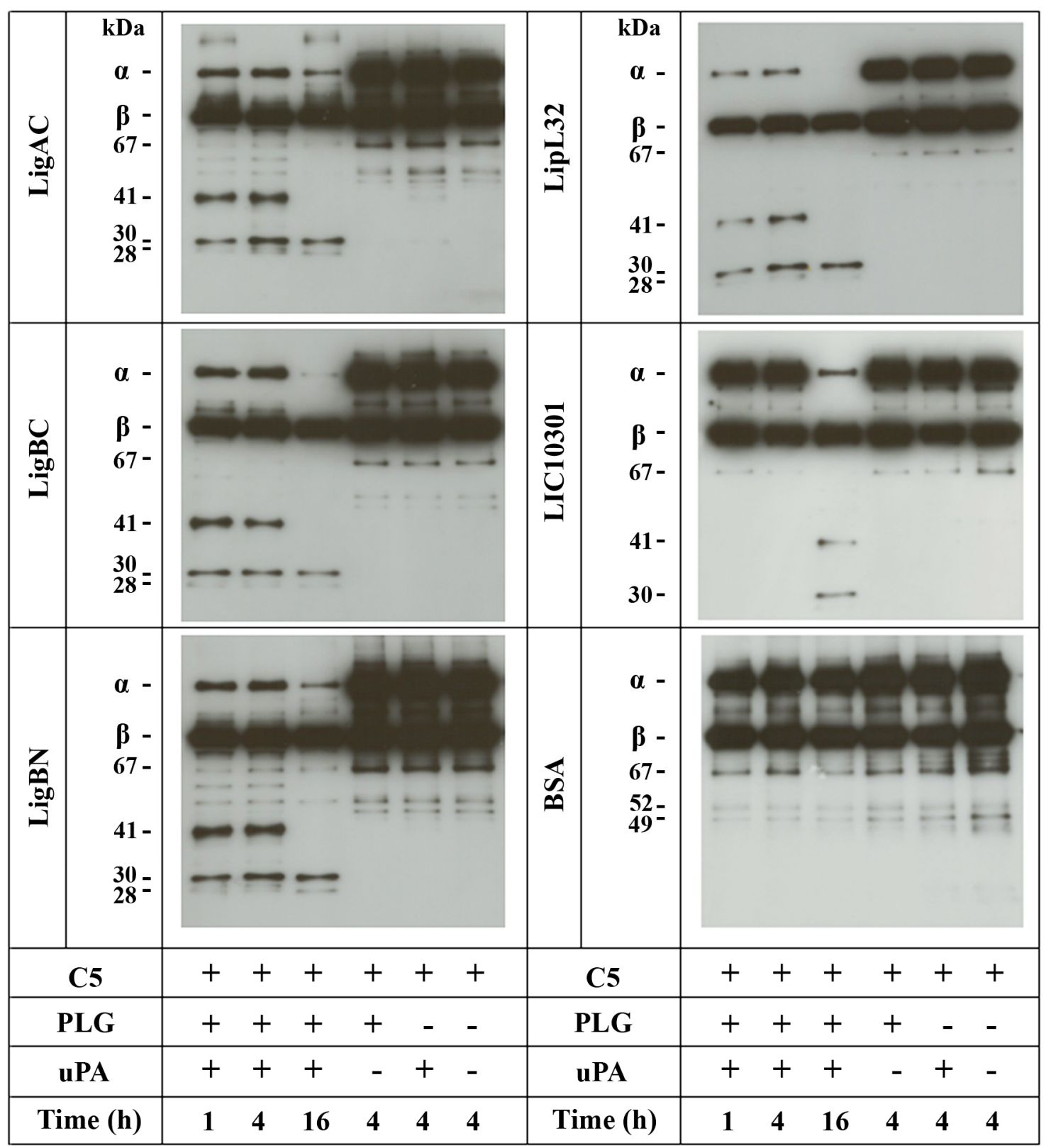

Proteínas recombinantes de L. interrogans LigAC, LigBC, LigBN, LipL32 ou LIC10301 (10 $\mu \mathrm{g} / \mathrm{ml})$, foram incubadas com plasminogênio (PLG, $20 \mu \mathrm{g} / \mathrm{ml}$ ). Após lavagens, C5 (500 ng) e uPA (3 U) foram adicionados e incubados nos três tempos indicados. Os produtos da incubação foram separados por SDS-PAGE, transferidos para membranas de nitrocelulose e detectados com anti- C5 policlonal feito em cabra seguido por incubação com anti-IgG de cabra conjugado com peroxidase. Como controles das clivagens foram omitidos uPA ou PLG na incubação. Experimento representativo de 3 experimentos independentes. 
4.21 Análise da competição entre plasminogênio e FH ou C4BP por sítios de ligação nas proteínas Ligs

Além de se ligar aos reguladores FH e C4BP do sistema complemento, as proteínas LigA e LigB de L. interrogans ligam-se ao plasminogênio. Decidimos investigar se elas competiriam entre si, pelos mesmos sítios de ligação nas proteínas Lig. As proteínas LigAC, LigBC e LigBN $(10 \mu \mathrm{g} / \mathrm{ml})$ foram imobilizadas em placas de ELISA e incubadas com a concentração fixa de $1 \mu \mathrm{g}$ de PLG e com diferentes concentrações FH ou C4BP. Todas as proteínas foram detectadas com anticorpos específicos (Figura 47).

Nas condições realizadas, quantidades elevadas de C4BP e FH não afetaram a interação entre as Ligs e plasminogênio, sugerindo que possivelmente estas moléculas possuam sítios diferentes de ligação (Figura 47 e 48). Quando foram adicionadas diferentes concentrações de $\mathrm{FH}$, a porcentagem de ligação de plasminogênio às proteínas Ligs apresentou redução de 15\%, principalmente com a proteína LigBN. Embora essa diferença seja estatisticamente significativa em alguns pontos, não é possível afirmar que há competição entre FH e plasminogênio pelos sítios de ligação na porção N-terminal da proteína LigB, pois, quando quantidades maiores de plasminogênio foram utilizadas, esta diferença não foi observada e, além disso, a interação com FH não foi afetada. 
Figura 47 - Análise da competição entre plasminogênio e FH por sítios de ligação nas proteínas Ligs

LigAC

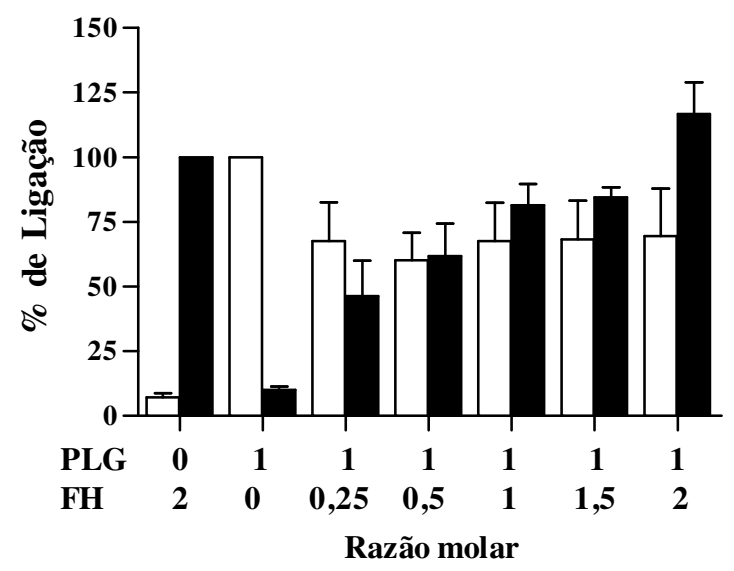

LigBC

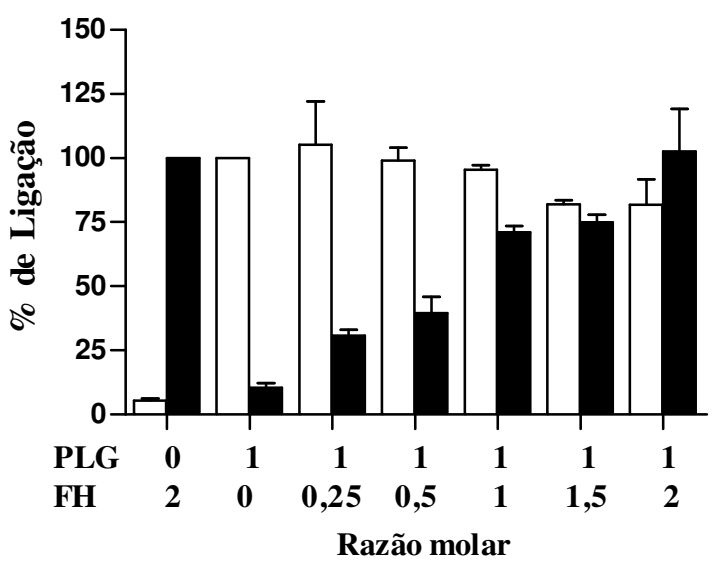

\section{LigBN}

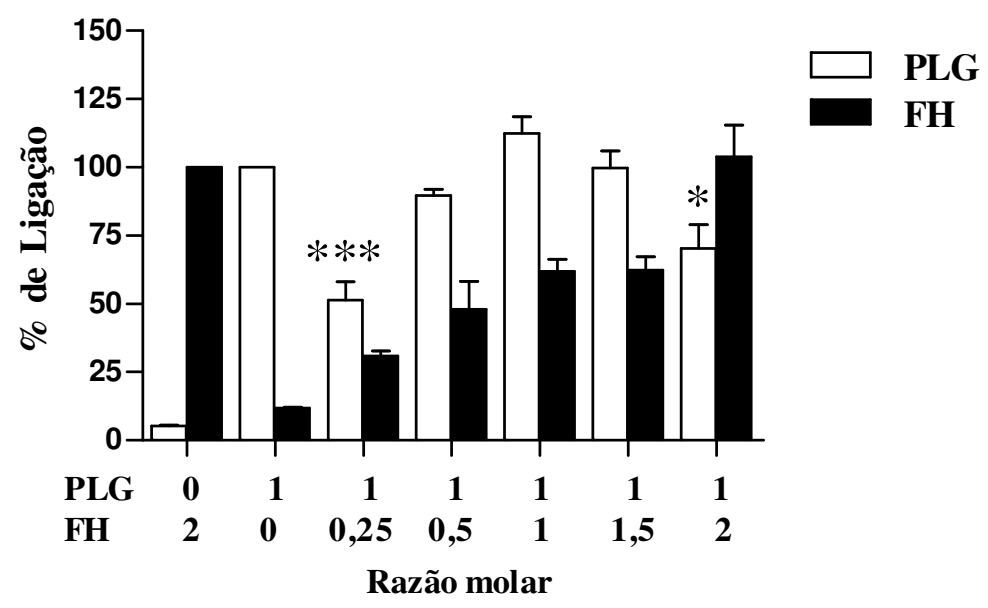

As proteínas $\operatorname{LigAC}$, $\operatorname{LigBC}$ e $\operatorname{LigBN}(15,7 \mu \mathrm{g} / \mathrm{ml})$ foram incubadas com uma concentração fixa de PLG (10 $\mu \mathrm{g} / \mathrm{ml})$ e com concentrações crescentes de $\mathrm{FH}(0-20 \mu \mathrm{g} / \mathrm{ml})$ para determinar possível competição entre estes dois reguladores. A quantidade de proteína empregada de PLG em relação à de FH está apresentada em razão molar. As proteínas foram detectadas com anti- FH policlonal ou anti-PLG (anti kringle 5) seguidos do anti- IgG conjugado com peroxidase. O resultado representa a média da porcentagem de ligação de FH ou PLG às proteínas recombinantes de três experimentos diferentes. A significância estatística foi analisada pelo teste ANOVA, $*(p>0,05)$. 
Figura 48 - Análise da competição entre plasminogênio e C4BP por sítios de ligação nas proteínas Ligs

\section{$\operatorname{LigAC}$}

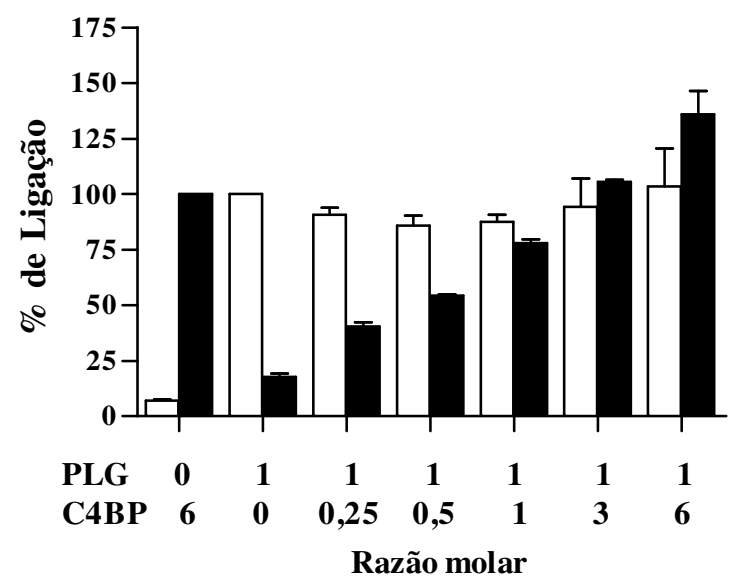

LigBC

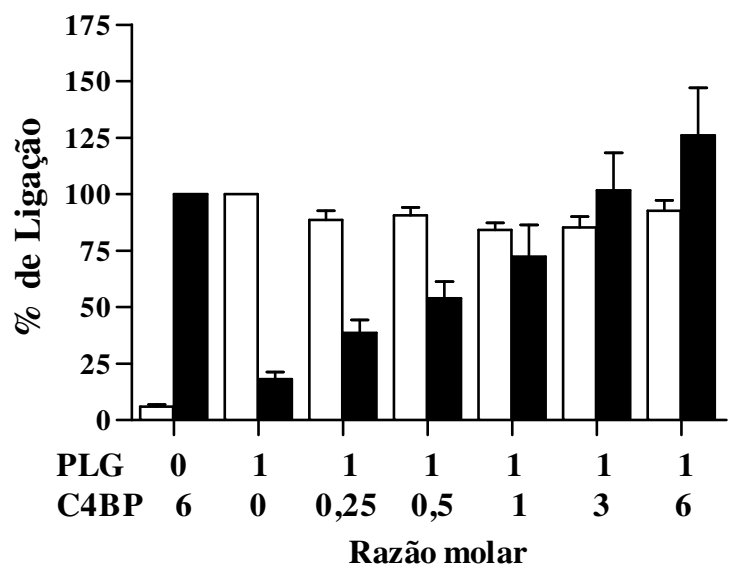

\section{LigB N}

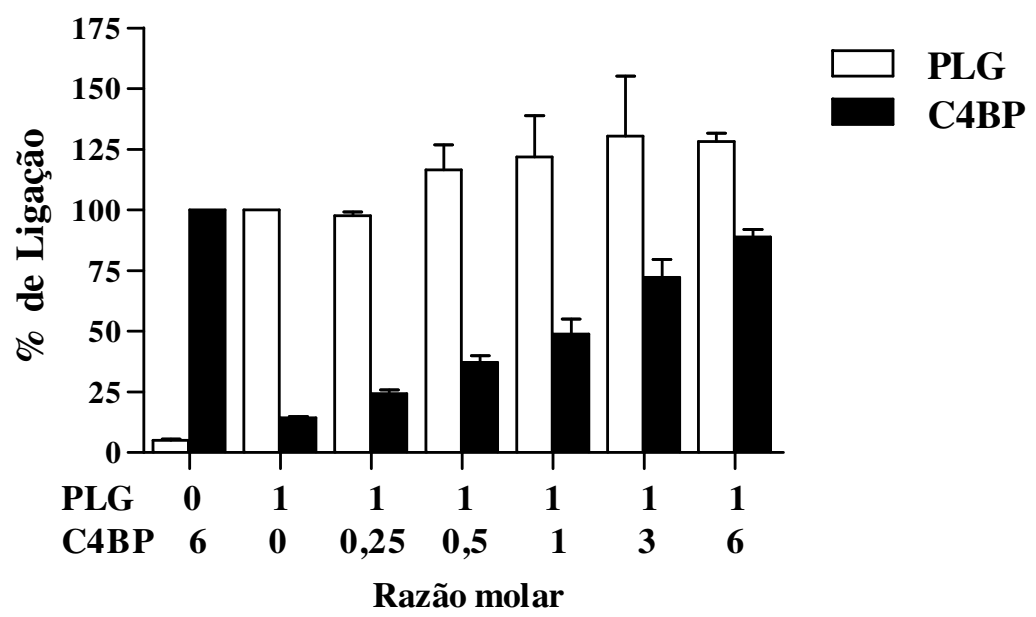

As proteínas $\operatorname{LigAC}$, $\operatorname{LigBC}$ e $\operatorname{LigBN}(15,7 \mu \mathrm{g} / \mathrm{ml})$, foram incubadas com uma concentração fixa de plasminogênio (PLG, $10 \mu \mathrm{g} / \mathrm{ml})$ e com concentrações crescentes de FH $(0-20 \mu \mathrm{g} / \mathrm{ml})$ para determinar possível competição entre estes dois reguladores. A quantidade de proteína empregada de PLG em relação à de FH está apresentada em razão molar. As proteínas foram detectadas com anti- C4BP policlonal ou anti-PLG (anti kringle 5) seguidos do anti- $\operatorname{IgG}$ conjugado com peroxidase. $\mathrm{O}$ resultado representa a média da porcentagem de ligação de FH ou PLG às proteínas recombinantes de três experimentos diferentes. A significância estatística foi analisada pelo teste ANOVA, $*(p>0,05)$. 
4.22 Interação de leptospiras com polimorfonucleares

O FH ligado à superfície das leptospiras pode mediar a interação entre bactérias e fagócitos, uma vez que FH também interage com CR3. Com o objetivo de determinar se esta interação poderia acontecer, PMNs humanos foram estimulados com leptospiras patogênicas e não patogênicas na presença ou ausência de proteínas purificadas e soro humano normal como fonte de complemento. A capacidade de produção de espécies reativas de oxigênio (ROS) derivada da ativação dos PMNs foi avaliada por citometria de fluxo usando dihidrorodamina123 (DHR), uma molécula muito utilizada na detecção de radicais livres e espécies reativas de oxigênio, devido à sua capacidade de emitir fluorescência. Na presença destas substâncias a dihidrorodamina oxida e forma a rodamina, que é fluorescente.

Os PMNs, foram obtidos a partir do sangue periférico. As populações celulares foram separadas por tamanho (FSC) e granulosidade (SSC). Como estratégia de análise foram selecionados por meio de um gate as populações celulares com maior presença de neutrófilos e monócitos (Figura 49) por serem estas células as maiores produtoras de espécies reativas de oxigênio.

Figura 49 - Separação por citometria de fluxo das populações celulares presentes no sangue.

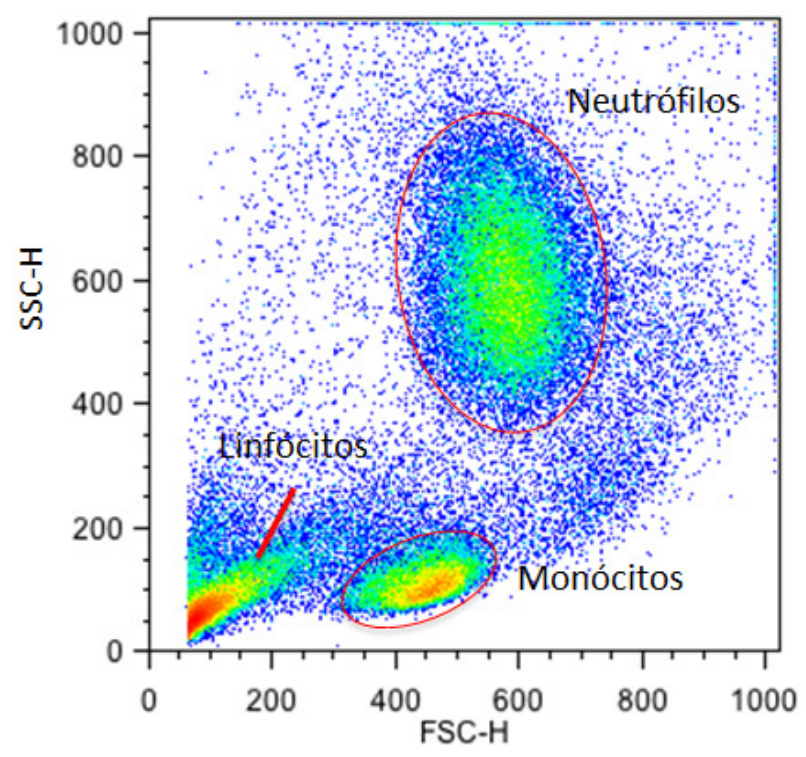

Desenho da estratégia de gate realizada para separação por citometria de fluxo das populações celulares mais ricas em neutrófilos e monócitos presentes no sangue. A separação foi feita por tamanho (FSC) e granulosidade (SSC) das diferentes populações celulares. Os neutrófilos, por serem células mais complexas estruturalmente, possuem maior granulosidade. Neste gráfico podem ser visivelmente observáveis as diferentes populações onde se encontram predominantemente neutrófilos, monócitos e linfócitos. 
Primeiro decidimos determinar se a ativação dos PMNs seria dependente ou não de complemento. Para isto, leptospiras patogênicas e não patogênicas foram pré-incubadas com $20 \%$ de SHN, SHN inativado a $56{ }^{\circ} \mathrm{C}$ e SHN + EDTA empregados como controles negativos de ativação por complemento. Posteriormente, as bactérias foram co-incubadas com PMNs com o objetivo de analisar a produção de espécies reativas de oxigênio nos diferentes tratamentos. No entanto, como leptospiras não patogênicas morrem mais rápido do que leptospiras patogênicas na presença de SHN, analisamos a sobrevida destas bactérias em diferentes quantidades de $\operatorname{SHN}(10 \%, 15 \%$ e $20 \%)$ para determinar qual seria a melhor porcentagem de soro para estimular os PMNs e se esta quantidade manteria as bactérias vivas pelo período de incubação. Nossos resultados mostraram que bactérias pré-incubadas $20 \%$ de SHN (Figura 51) ativaram melhor os PMNs e os experimentos de sobrevivência também demonstraram que bactérias patogênicas e não patogênicas incubadas com $20 \%$ de SHN sobrevivem $55 \%$ e $35 \%$ respectivamente (Figura 50).

Figura 50 - Análise da sobrevida de L. biflexa e L. interrogans na presença de diferentes quantidades de SHN

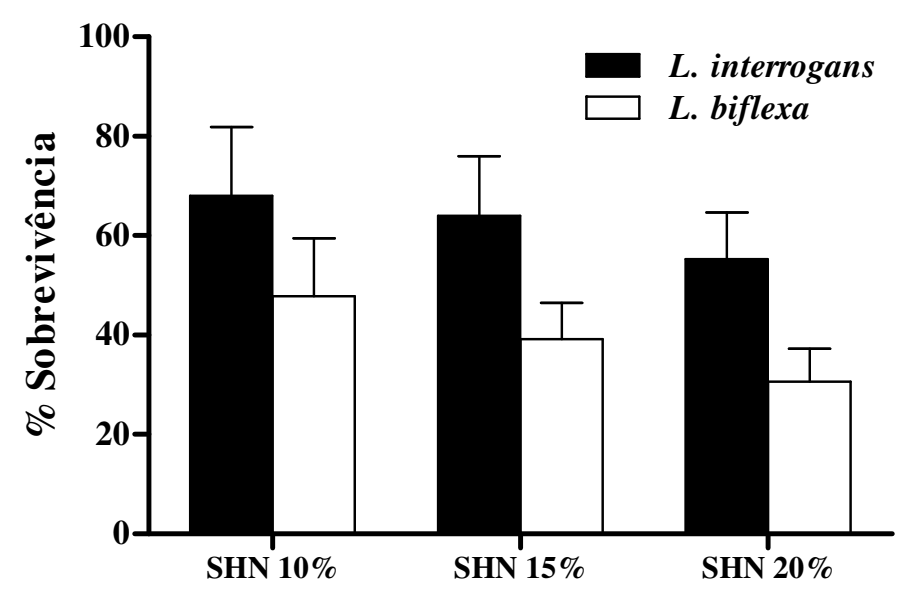

Culturas de L. biflexa e L. interrogans $\left(1 \times 10^{8}\right)$ foram incubadas por 1 hora com $10 \%, 15 \%$ e $20 \%$ de SHN. Após incubação, as leptospiras sobreviventes foram contadas por microscopia de campo escuro. Estes dados representa uma média de três experimentos diferentes.

Leptospiras não patogênicas (L. biflexa) opsonizadas com SHN ativam mais os polimorfonucleares que as patogênicas (L. interrogans), gerando espécies reativas de oxigênio. A ativação das leptospiras é claramente aumentada na presença do complemento já 
que, quando o soro foi inativado pelo calor ou tratado com EDTA, a ativação dos PMN foi diminuída tanto em neutrófilos como em monócitos (Figura 51).

Depois de ter confirmado que o sistema complemento contribui para a ativação dos PMN co-incubados com leptospiras opsonizadas com SHN, decidimos avaliar quais proteínas do sistema complemento estimulariam os PMNs. Para isto pré-incubamos as bactérias com $20 \%$ de soros comerciais depletados de C3, C5 ou de FH. Não entanto, não observamos diferenças significativas entre eles e, além disso, nenhum desses soros conseguiu ativar os PMN como o SHN (Figura 52). Para melhor avaliar o papel que exercem as proteínas C3, C5 e FH na ativação dos PMN resultando no aumento da produção de espécies reativas de oxigênio foram empregadas proteínas purificadas de complemento ( $\mathrm{C} 3 \mathrm{~b}$, iC3b, $\mathrm{FH}$ ) conhecidas por estimular CR3. Nossos resultados mostram que leptospiras não patogênicas ativam melhor os PMNs quando opsonizadas com $\mathrm{C} 3 \mathrm{~b}, \mathrm{iC} 3 \mathrm{~b},(\mathrm{C} 3 \mathrm{~b}+\mathrm{FH}+\mathrm{FI})$ e $(\mathrm{FH}+\mathrm{C} 3 \mathrm{~b})$ do que leptospiras patogênicas (Figura 53). Cabe resaltar que os tratamentos em que as leptospiras não patogênicas ativaram melhor os PMNs foram aqueles onde $\mathrm{C} 3 \mathrm{~b}$ ou iC3b estiveram presentes. Porém, leptospiras patogênicas regularam a deposição de $\mathrm{C} 3 \mathrm{~b}$ ou iC $3 b$ na sua superfície, devido à secreção de proteases ou regulação graças à interação com FH, impedindo desta maneira a deposição destas moléculas importantes para incrementar a ativação dos PMNs. 
Figura 51 - Produção intracelular de espécies reativas de oxigênio (ROS) em PMN coincubados com leptospiras opsonizadas com SHN
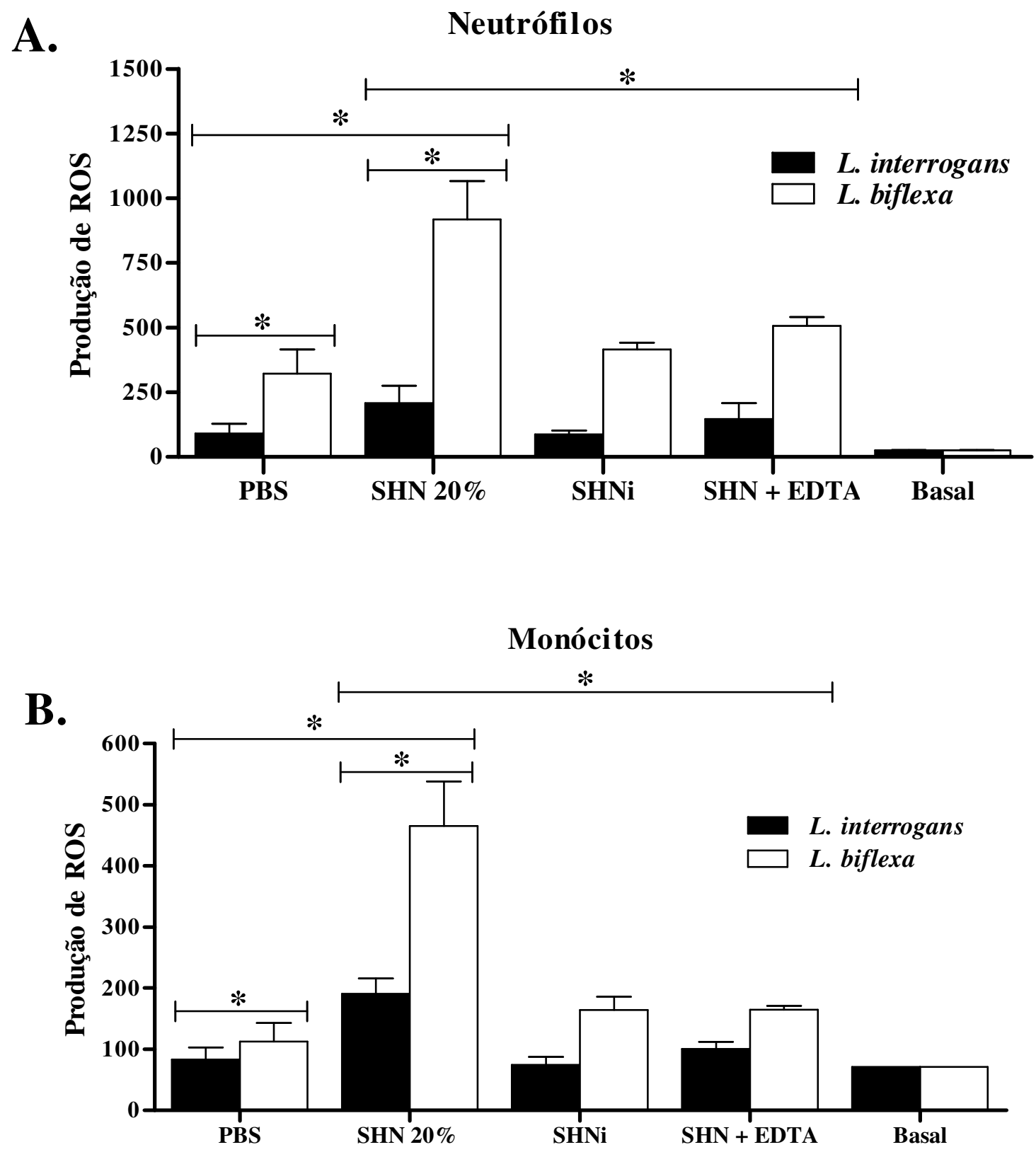

A produção intracelular de espécies reativas de oxigênio em PMN foi detectada por citometria de fluxo usando dihidrorodamina-123, após co-incubação com $1 \times 10^{8}$ leptospiras patogênicas L. interrogans sorovar Pomona estirpe Fromm ou não patogênicas L. biflexa estirpe Patoc pré-incubadas com SHN (20\%), Soro humano normal inativado a $56{ }^{\circ} \mathrm{C}$ por $30 \mathrm{~min}$ ou com EDTA $100 \mathrm{mM}$. (A) População celular composta predominantemente por neutrófilos e (B) por monócitos. Os resultados expressam a média relativa de fluorescência (MFI) que reflete a produção de ROS. Resultados obtidos de 3 experimentos diferentes. A significância estatística foi analisada por ANOVA, $*(p<0.005)$. 
Figura 52 - Produção intracelular de espécies reativas de oxigênio (ROS) em PMN coincubados com leptospiras opsonizadas com soros humanos depletados de C3, $\mathrm{C} 5$ ou de $\mathrm{FH}$

A.

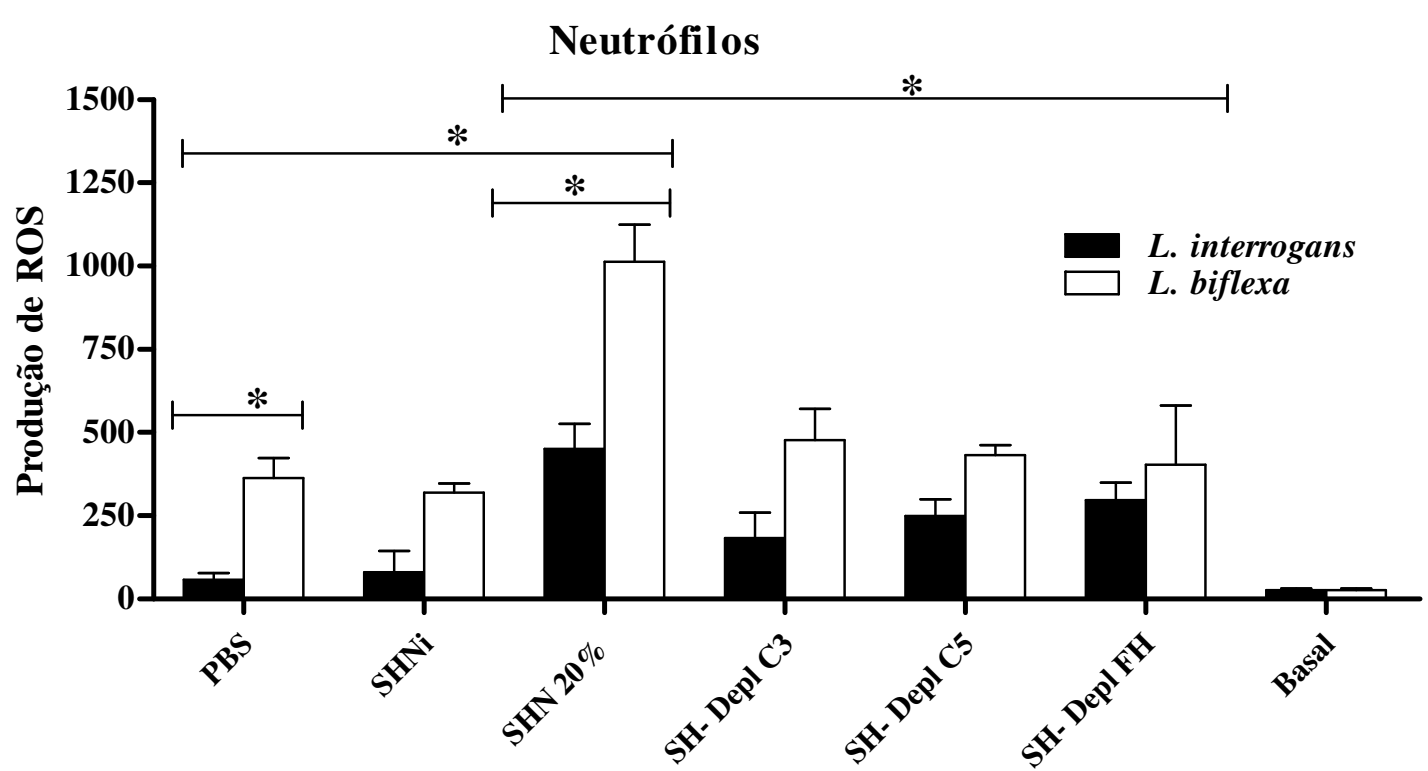

B. Monócitos

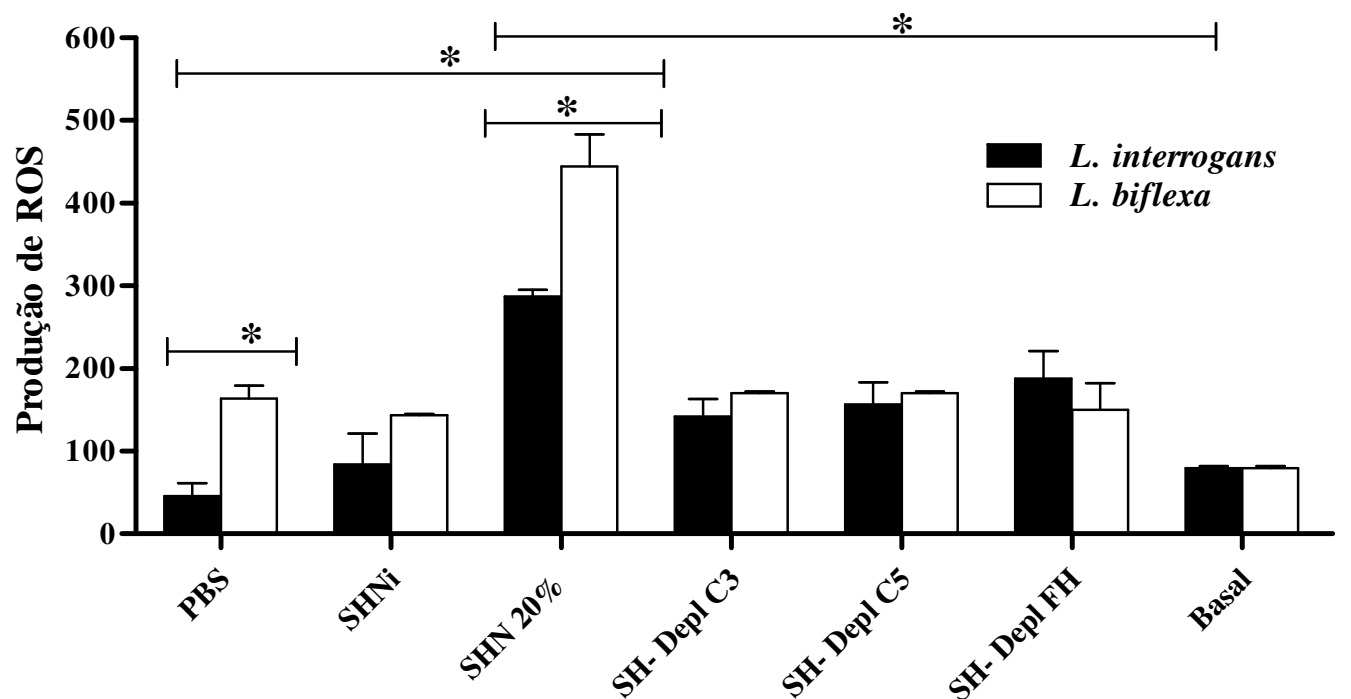

produção intracelular de espécies reativas de oxigênio em PMN foi detectada por citometria de fluxo usando dihidrorodamina-123, após co-incubação com $1 \times 10^{8}$ leptospiras patogênicas L. interrogans sorovar Pomona estirpe Fromm ou não patogênicas L. biflexa estirpe Patoc pré-incubadas com SHN e soros depletados de C3, C\% e FH. (A) População celular composta predominantemente por neutrófilos e (B) monócitos. Os resultados expressam a média relativa de fluorescência (MFI) que determina a produção de ROS. Resultados obtidos de 3 experimentos diferentes. A significância estatística foi analisada por ANOVA, $*(p<0.005)$. 
Figura 53 - Produção intracelular de espécies reativas de oxigênio (ROS) em PMN coincubados com leptospiras opsonizadas com diferentes proteínas do complemento

A.

\section{Neutrófilos}

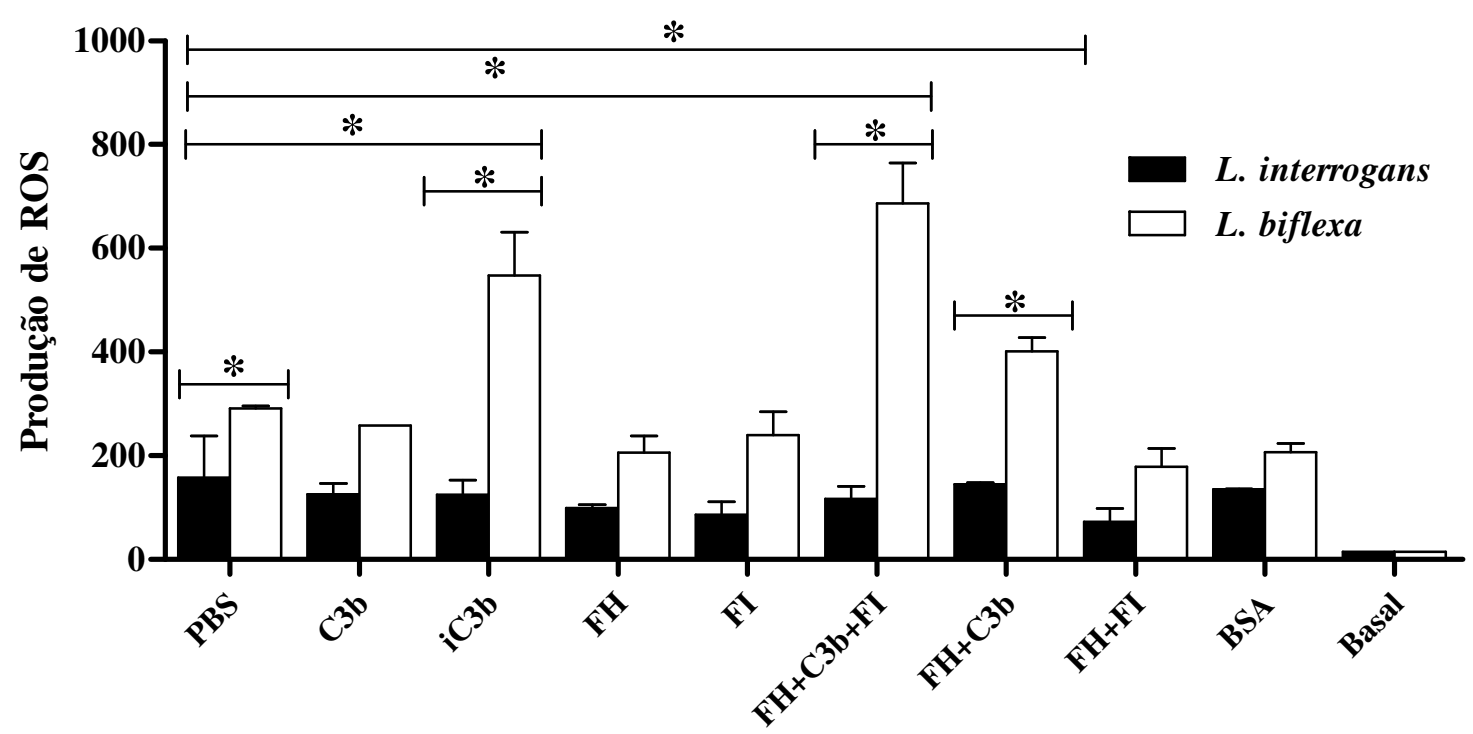

B.

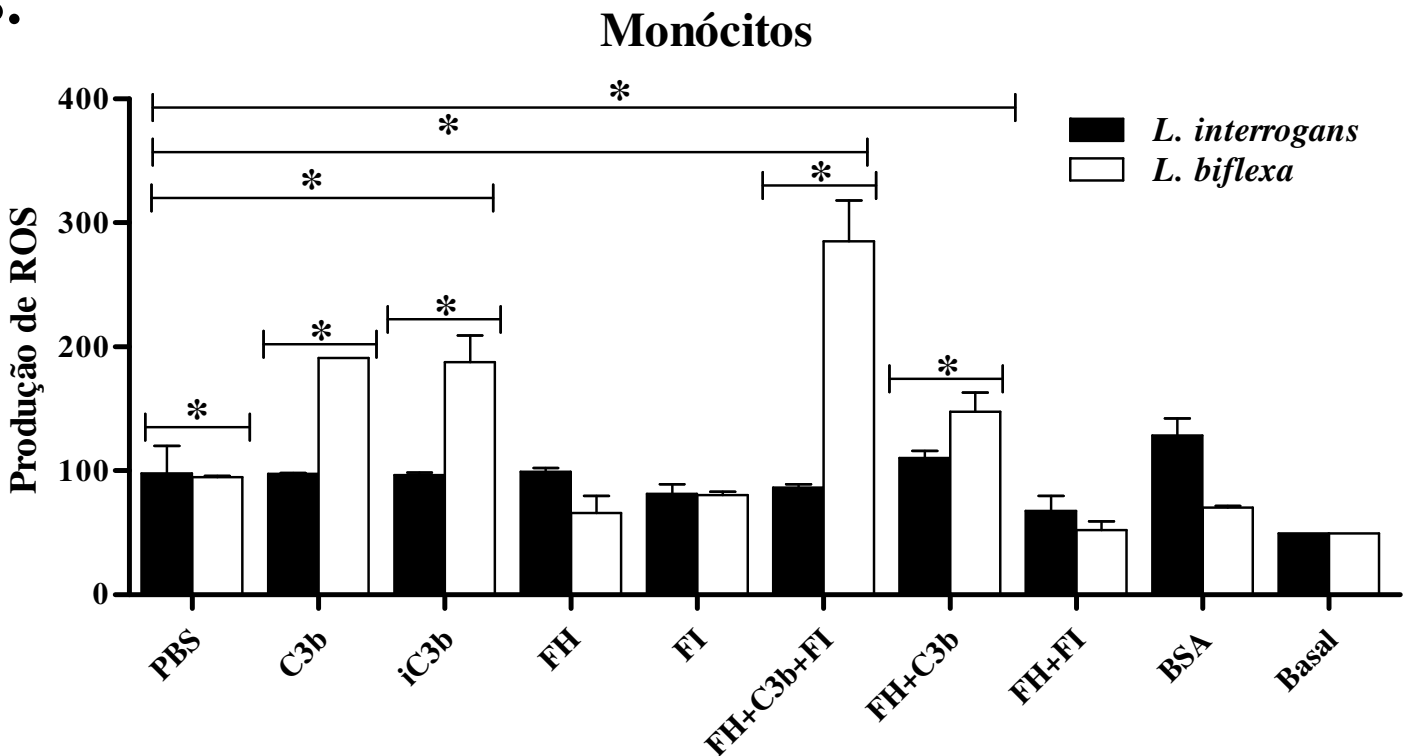

A produção intracelular de espécies reativas de oxigênio em PMN foi detectada por citometria de fluxo usando dihidrorodamina-123, após co-incubação com $1 \times 10^{8}$ leptospiras patogênicas L. interrogans sorovar Pomona estirpe Fromm ou não patogênicas $L$. biflexa estirpe Patoc pré-incubadas com proteínas purificadas de complemento. (A) População celular composta predominantemente por neutrófilos e (B) monócitos. Os resultados expressam a média relativa de fluorescência (MFI) que determina a produção de ROS. Resultados obtidos de 3 experimentos diferentes. A significância estatística foi analisada por ANOVA, $*(p<0.005)$. 


\section{DISCUSSÃO}

A primeira linha de defesa contra patógenos é fornecida pela imunidade inata, da qual o sistema complemento é constituinte particularmente importante (Dempsey et al., 1996; Medzhitov et al., 2000). Micro-organismos são geralmente reconhecidos e eliminados pelo sistema complemento e demais participantes da resposta imune do hospedeiro. No entanto, ao longo da evolução, os patógenos desenvolveram um amplo número de estratégias de controle, modulação e bloqueio em resposta aos ataques do sistema complemento. Desta maneira, micróbios patogênicos conseguem sobreviver no organismo imunocompetente, controlando de maneira eficiente os mecanismos da resposta imune inata e adaptativa (Blom et al., 2009; Lambris et al., 2008; Zipfel et al., 2013).

Por outro lado, leptospiras não patogênicas são facilmente eliminadas pela imunidade inata do hospedeiro. Os primeiros estudos que avaliaram a sobrevivência de espécies de leptospiras patogênicas em hospedeiros mostraram que a resistência era diretamente proporcional à capacidade de controlar a ativação da via alternativa do sistema complemento (Anderson et al., 1968; Banfiet al., 1982 Johnson et al.,1966; Meri et al., 2005). Experimentos realizados pelo nosso grupo demonstraram que leptospiras patogênicas resistem à morte pelo sistema complemento na presença de SHN (Barbosa et al., 2009).

Aparentemente, as leptospiras patogênicas possuem mecanismos de proteção contra componentes da imunidade inata como fagócitos e proteínas do sistema complemento. Sabese que leptospiras patogênicas são invasivas e podem se multiplicar no sangue, aderir às células do hospedeiro e penetrar os tecidos. Contudo, pouco se conhece sobre os fatores de virulência envolvidos nos diferentes mecanismos de evasão. Com base nestas observações, decidimos investigar quais proteínas de membrana de leptospiras patogênicas estariam participando ativamente nestes mecanismos.

Trabalhos anteriores demonstraram que leptospiras patogênicas interagem com FH e FHR-1, presentes no soro (Meri et al., 2005). Neste trabalho demonstramos que, além de interagir com estes dois reguladores, as leptospiras também interagem com FHL-1 recombinante (Figura 22A). Nos experimentos realizados por Meri et al. (2005) não foi possível apontar a ligação de FHL-1 em leptospiras, uma vez que FHL-1 e FHR-1 possuem tamanhos moleculares aproximados [42 kDa (FHL-1) e 43 kDa (FHR-1)], dificultando sua distinção por migração electroforética em SDS-PAGE. Porém, a interação com FHL-1 não parece ser de grande relevância para esta espiroqueta, uma vez que perfis semelhantes de 
produtos de clivagens de $\mathrm{C} 3 \mathrm{~b}$ foram observados tanto na presença como na ausência desta proteína (Figura 22B).

Contudo, a interação com FHR-1 também pode oferecer vantagens para a bactéria, pois FHR-1 pode inibir a atividade da C5 convertase, interferindo assim com a deposição de C5b e formação do MAC (Heinen et al., 2009). Esta atividade pode ser benéfica para um grande número de bactérias e fungos patogênicos (Behnsen et al., 2008; Haupt et al., 2007; Kunet et al., 2007; Rossmannet al., 2007), os quais, além de interagirem com FH, também ligam FHR-1, permitindo controlar a ativação do sistema complemento nas etapas iniciais e tardias da cascata de ativação.

Proteínas da família do FH, uma vez ligadas em micro-organismos, também podem mediar a adesão e facilitar a invasão de células do hospedeiro (Hammerschmidt et al., 2007, Pandiripally et al., 2003). Por outro lado, a ligação de FHR-1 ligado à superfície do patógeno pode ser uma vantagem para o hospedeiro por duas razões: a primeira, porque FHR-1 poderia competir com FH devido à homologia dos domínios SCRs, reduzindo o controle do sistema complemento sobre a superfície do patógeno (Hauptet et al., 2007); e segundo porque FH e FHR-1 juntos poderiam mediar a adesão dos patógenos às células do sistema imune do hospedeiro e desencadear sua atividade microbicida, como mostram estudos realizados com C. albicans (Losse et al., 2010), onde FH e FHR-1 mediam a adesão destas leveduras aos neutrófilos, intensificam o processo fagocítico e aumentam a produção de espécies reativas de oxigênio e lactoferrina.

Outro ponto interessante para ressaltar deste trabalho foi que observamos que $L$. interrogans exibe atividade reguladora do sistema complemento, secretando proteases ou interagindo com reguladores do hospedeiro, capazes de clivar moléculas-chave inibindo assim, a ativação deste sistema (Figura 22B). Estes resultados foram validados por nosso grupo, quando demonstramos que proteases secretadas por leptospiras patogênicas inibem a ativação das três vias do sistema complemento. Esta inibição foi diretamente relacionada com a clivagem de proteínas importantes deste sistema como C3b, FB, C4 e C2 (Fraga et al., 2014). Outro dado importante é que estas proteases conseguem trabalhar sinergicamente com os reguladores FH e FI na inativação de C3b. Este sinergismo entre reguladores do hospedeiro e proteases já foi descrito anteriormente em outros patógenos como S. fecalis (Park et al., 2008) e S. aureus (Laaman et al., 2011). As proteases secretadas por estes patógenos conseguem clivar a cadeia $\alpha$ da molécula de $\mathrm{C} 3$ gerando $\mathrm{C} 3 \mathrm{~b}$-like, susceptível à degradação pelo FI na presença do FH. 
Nossos experimentos também mostraram que na presença de L. interrogans a clivagem de $\mathrm{C} 3 \mathrm{~b}$ na presença de $\mathrm{FH}$ é muito mais eficiente, dado confirmado pelo completo desaparecimento da cadeia $\alpha^{\prime}(110 \mathrm{kDa})$ e a acentuada geração de produtos de clivagem de 28 $\mathrm{kDa}$ a $43 \mathrm{kDa}$ (Figura 22B) derivados de C3b. Neste contexto, a secreção de proteases poderia conferir uma vantagem adicional para a sobrevida das leptospiras patogênicas no hospedeiro.

Neste trabalho, nós demonstramos que a aquisição de FH pelas leptospiras patogênicas representa um papel protetor, sendo crucial para a sobrevida desta bactéria (Figura 30). A real importância do FH para a sobrevida de leptospiras patogênicas ficou evidenciada, quando incubamos estas bactérias com soro humano depletado de FH e apenas $30 \%$ delas sobreviveram. Ao reconstituir este mesmo soro depletado com quantidades crescentes (até atingir concentrações fisiológicas) de FH purificado, as bactérias foram recuperando gradualmente a habilidade de sobreviver à ação do sistema complemento. A porcentagem de leptospiras que consegue sobreviver na presença de soro humano depletado de FH poderia ser atribuída a outros mecanismos de evasão empregados pela bactéria, como, por exemplo, sua capacidade de interagir com C4BP (Barbosa et al., 2009), secreção de proteases que clivam componentes do sistema complemento (Fraga et al., 2014), ou a presença de proteínas de leptospira que poderiam apresentar função análoga às proteínas reguladoras de membrana do sistema complemento como membrane co-factor protein (MCP), decay accelerating factor (DAF), CD59, etc.

A depleção de FH do soro humano claramente diminuiu a sobrevida de leptospiras patogênicas in vitro, ocorrida na ausência de células. Este resultado indica que, pelo menos in vitro, a lise mediada pelo sistema complemento deve ser o principal mecanismo efetor de eliminação de leptospiras dependente de proteínas séricas. Resta ainda confirmarmos in vivo em animais infectados com leptospiras patogênicas se o controle da infecção depende mais da lise ou da facilitação da fagocitose mediada por opsoninas, geradas em função da ativação do sistema complemento.

A relevância da função do FH como mecanismo de evasão à morte pelo sistema complemento foi claramente evidenciada pelo aumento da sobrevivência das leptospiras patogênicas capazes de interagir com FH. No entanto, até o início deste trabalho, somente a proteína LenA tinha sido descrita como ligante de FH presente na membrana da leptospira (Verma et al., 2006). Nós demonstramos que além de LenA existem outras proteínas de membrana presentes exclusivamente nas leptospiras patogênicas capazes de interagir com $\mathrm{FH}$ e C4BP como as proteínas LIC10657, LIC11087 e as proteínas Ligs. As proteínas Ligs são 
importantes fatores de virulência e a perda da sua expressão está correlacionada com a perda da virulência durante a atenuação em cultura. No entanto, durante a infecção elas são superexpressadas (Choy et al., 2007; Matsunanga et al., 2003, 2007; Palaniappan et al., 2004). Estas proteínas interagem com uma diversa lista de moléculas, incluindo proteínas de matriz extracelular e da cascata de coagulação (Choy et al., 2007; Lin, Chan 2007; Lin et al., 2009, 2010). Considerando que as Ligs são promissores candidatos vacinais e apresentam uma grande diversidade funcional, decidimos focalizar nossos experimentos nesta interessante família de proteínas.

Nossos resultados demonstraram que LigA e LigB ligam FH e C4BP purificados ou como parte do soro, de maneira dose-dependente, pelas regiões $\mathrm{N}$ - e $\mathrm{C}$ - terminal dessas duas proteínas reguladoras do sistema complemento. Estas duas proteínas, quando ligadas às proteínas Ligs, são capazes de atuar como co-fatores na geração de fragmentos de clivagens de C3b e C4b na presença de FI (Figuras 26 e 28).

A clivagem de $\mathrm{C} 4 \mathrm{~b}$ foi muito mais eficiente na presença de C4BP purificada do que na presença de SHN. Isto sugere a possibilidade de outras proteínas presentes no soro competirem com C4BP pelos mesmos sítios de ligação nas proteínas Ligs. Porém, nossos dados indicam que C4BP não inibe a interação entre FH e LigAC, LigBC, ou LigBN (Figura 29), mesmo quando empregamos razões molares FH:C4BP acima daquelas encontradas no plasma (1 de FH: 0,125 de C4BP). Deste modo, os dois reguladores do sistema complemento poderiam se ligar simultaneamente nas proteínas Ligs.

Além de interagir com FH e C4BP, as proteínas Ligs também ligam FHL-1 e FHR-1 (Figuras 23, 24 e 25). Na tentativa de mapear os domínios de FH que interagem com as Ligs, foram empregadas construções recombinantes contendo diferentes SCRs de FH e anticorpos específicos contra algumas regiões deste regulador. Observamos que as proteínas Ligs provavelmente interagem com FH pelos SCRs 5-7 e também pela região carboxi-terminal SCRs 18-20 (Figura 31A e 31B). Isto está em acordo com a maioria das proteínas bacterianas que interagem com FH: PorB 1A, PorB 1B de N. gonorrhoeae (Ngampasutadol et al., 2008), Tuf de P. aeruginosa (Kunerteta al., 2007), CRASPs 3-5 de Borrelia spp (Kraiczy et al., 2001, 2003, 2004, 2006; Hartmann et al., 2006; Hovis et al., 2004; McDowell et al., 2003; Rossmann et al., 2007; Wallich et al., 2005), Omp de H. influenzae (Hallstrom et al., 2008), Sbi de S. aureus (Haupt et al., 2008), FhbB de T. denticola (McDowell et al., 2005), M e Fba de S. pyogenes (Blackmore et al., 1998), Fhpp de N. meningitidis (Shaughnessy et al., 2009).

Neste estudo nós demonstramos que estas proteínas multifuncionais Ligs também interagem com reguladores do sistema complemento. A capacidade de aderirem nas células 
do hospedeiro e matriz extracelular, assim como a capacidade para escapar do sistema complemento são duas atividades fundamentais que contribuem para a colonização bem sucedida no hospedeiro. Uma possível explicação para o êxito destas proteínas como antígenos vacinais é que anticorpos específicos contra as Ligs conseguem bloquear a interação dos reguladores do sistema complemento e moléculas de matriz extracelular com a superfície bacteriana, deixando a bactéria suscetível à morte mediada pelo sistema complemento. No entanto, embora as proteínas Ligs pareçam ser importantes fatores de virulência, experimentos de mutagênese com $\operatorname{LigB}$ demonstraram que a ausência desta proteína não resultou na perda da virulência (Croda et al., 2008). No entanto, dificilmente o processo de mutagênese per se, conseguiria afetar completamente a virulência bacteriana, uma vez que há redundância funcional entre diversas proteínas presentes na membrana de leptospira incluindo a LigA (McBride et al., 2008). Para determinar a verdadeira importância desta família de proteínas como fatores de virulência relevantes para o processo de evasão à ação do sistema complemento, empregamos leptospiras não patogênicas (L. biflexa) transgênicas expressando LigA ou LigB (Figueira et al., 2010). Nossos resultados demonstraram que leptospiras transgênicas para LigA ou LigB sobrevivem in vitro melhor do que a cepa selvagem no soro (Figura 32), confirmando que a presença das proteínas Ligs está diretamente envolvida com os mecanismos de evasão à morte pelo sistema complemento.

Nós também demonstramos que leptospiras transgênicas (L. biflexa expressando LigA ou LigB) conseguem regular melhor a deposição de C3 (ou de fragmentos de C3) do que a cepa selvagem (L. biflexa). Esta deposição mostrou estar diretamente relacionada com a formação do MAC, pois, quanto menor a deposição de C3 na membrana, menor a formação de MAC. A presença das proteínas Ligs na membrana das bactérias transgênicas pode ser a explicação mais plausível para a inibição da deposição destas moléculas, uma vez que estas proteínas oferecem às bactérias a capacidade de interagir com FH e C4BP (Figura 33A e 33B).

Estudos anteriores também mostraram a importância da aquisição de PLG como um mecanismo facilitador da invasão de tecidos empregado por diversos patógenos (Coleman et al., 1995; Fuchs et al., 1996; Klempner et al., 1996; Kunert et al., 2007). Há vários anos foi relatado que L. interrogans interage com PLG e que, na presença dos ativadores exógenos presentes no hospedeiro como uPA, é ativado em PLA (Vieira et al., 2009). Até a presente data não foi descrito em leptospira nenhum ativador endógeno de PLG, mas já foram identificadas várias proteínas de membrana como ligantes desta molécula: LipL32, rLIC12730, rLIC10494, Lp29, Lp49, Lp40, MPL36, rLIC12238 (Vieira et al., 2010), LenA 
(Verma et al., 2010), OmpA-like (Oliveira et al., 2011), Lsa20 (Mendes et al., 2011), OmpL-1 (Fernandes et al., 2012), Lsa23, Lsa26, e Lsa36 (Siqueira et al.,2013), Lsa 33 (Domingos et al., 2012), Lsa30 (Spuza et al., 2012) EF-Tu (Wolff et al., 2013), Lsa44 e Lsa45 (Fernandes et al., 2014) e enolase (Nogueira et al., 2013).

Todavia, estudos mais recentes demonstraram que PLG, quando convertido em PLA, funciona como um novo inibidor da ativação das três vias do sistema complemento pela clivagem dos componentes C3b e C5 (Barthel et al., 2012). Todos os estudos anteriores realizados em leptospira, com exceção do realizado pelo nosso grupo com a proteína EF-Tu (Wolff et al., 2013), apresentaram a interação com PLG como mecanismo que pode contribuir para o processo de infecção. Neste trabalho nós demonstramos que, além de poder contribuir para a infecção, o PLG ligado às proteínas Ligs funciona como um possível mecanismo de escape da morte da leptospira pelo sistema complemento. Os resultados por Western blot e ELISA confirmaram uma interação direta das proteínas Ligs com PLG (Figura 39 e 40).

Apesar de alguns estudos demonstrarem que interações entre PLG e proteínas de membrana de diversos patógenos não são afetadas por forças iônicas (Brissette et al., 2009; Koenigs et al., 2013), observamos uma redução de 25\% da ligação de PLG nas proteínas Ligs na presença de $100 \mathrm{mM}$ de $\mathrm{NaCl}$ e a interação tendeu a diminuir mais ainda conforme aumentaram as concentrações desse sal (Figura 41). Em leptospiras a interação entre PLG e as proteínas LipL 32 e LenA não é afetada pela presença de $\mathrm{NaCl}$ em condições fisiológicas $(150 \mathrm{mM}$ de $\mathrm{NaCl})$. No que diz respeito às proteínas Ligs, parece haver dependência de forças iônicas. Cabe ressaltar que, embora concentrações fisiológicas de $\mathrm{NaCl}$ interfiram na ligação das Ligs ao PLG, já foi demonstrado que nestas condições (150 mM de $\mathrm{NaCl}$ ) leptospiras patogênicas tendem a aumentar a expressão de alguns fatores de virulência, entre eles as proteínas Ligs. (Choy et al., 2007; Matsunanga et al., 2007). Sendo assim, quanto maior a expressão de proteínas ligantes de PLG possivelmente maior será a capacidade do patógeno para interagir com esta molécula. Interações entre PLG e C3b também são afetadas em concentrações de $150 \mathrm{mM}$ de $\mathrm{NaCl}$ (Barthel et al., 2012), uma vez mais confirmando a importância das forças iônicas neste tipo de interações.

A ligação de PLG às proteínas Ligs também mostrou ser dependente de resíduos de lisina (Figura 42), uma vez que concentrações a partir de $0,5 \mathrm{mM}$ de ACA afetam a interação entre PLG e as proteínas Ligs. Estes dados sugerem um relevante envolvimento dos domínios kringle na interação (Barthel et al., 2012).

Nossos resultados também mostram que PLG ligado às proteínas Ligs é convertido enzimaticamente em PLA pela adição do ativador uPA (Figura 43). Esta enzima foi capaz de 
degradar fibrinogênio (Figura 44), C3b e C5 (Figura 45 e 46), de maneira tempodependente. Isso mostra que a bactéria possui a capacidade de degradar moléculas do sistema complemento por dois sistemas diferentes. Os fragmentos produzidos pela degradação das moléculas do sistema complemento pela PLA diferem daqueles produzidos pelo FI.

Um amplo número de patógenos liga PLG na sua superfície e com isto diversos ligantes bacterianos têm sido identificados. Quase todas estas interações são mediadas por resíduos de lisina similares às interações observadas entre PLG e C3b ou C5, ou como demonstrado nos experimentos realizados na presença de ACA (Figura 42). Alguns exemplos de ligantes bacterianos identificados incluem Tuf de $H$ influenzae, PspC de $S$. pneumoniae, CRASP1 de B. burgodorferi e Pra1 e Gmp 1 de C. albicans (Agarwal et al., 2010; Barthel et al., 2012; Bergmann et al., 2004; Hallstrom et al., 2010; Kurnet et al., 2007; Luo et al., 2009).

A clivagem de C3b pela PLA não somente poderia contribuir para a inibição da ativação do sistema complemento, mas também pode regular a presença $\mathrm{C} 3 \mathrm{~b}$ na membrana afetando a opsonização do micro-organismo e, com isto, diretamente o processo da fagocitose. Alguns patógenos como B. anthracis podem fazer uso do PLG para regular a opsonização com o objetivo de evadir a fagocitose (Chung et al., 2011).

A interação das proteínas Ligs com PLG e FH poderia constituir também um mecanismo de evasão não só da morte pelo sistema complemento, mas também da ação microbicida dos fagócitos. No entanto, estudos recentes com outros patógenos como $C$. albicans (Losse et al., 2010) e N. gonorrhoeae (Agarwal et al., 2010) mostraram que a interação com FH poderia também contribuir para o processo fagocítico, já que FH poderia mediar a interação entre patógeno e fagócito via CR3, uma vez que estudos anteriores observaram a capacidade deste receptor para interagir também com FH (Avery et al., 1993; Discipio et al., 1998). Nós decidimos então explorar um pouco mais esta questão e investigar se o FH poderia servir como uma ponte de interação entre L. interrogans e PMN. Sendo assim, o FH poderia apresentar duas funções diferentes na infecção por leptospiras patogênicas: uma contribuindo para a evasão ao sistema complemento possibilitando a degradação da proteína C3b e outra se apresentando como uma função desvantajosa para o patógeno mediando a adesão e ativação dos fagócito via CR3.

Uma das principais consequências da interação com CR3 é o desencadeamento de respostas antimicrobianas como ativação de PMN seguida pela quase imediata geração de espécies reativas de oxigênio (ROS), processo este que ocorre normalmente quando patógenos opsonizados entram em contato com PMN (Losse et al., 2010). Contudo, nossos resultados mostraram que a ativação de neutrófilos por leptospiras é mais eficiente na 
presença do sistema complemento, pois leptospiras opsonizadas com soro ativam quase 3 vezes mais do que leptospiras não opsonizadas (Figura 51A e 51B). Estes resultados também confirmaram que a ativação das leptospiras é dependente do sistema complemento, uma vez que leptospiras pré-incubadas com soro humano inativado não apresentaram produção significativa de ROS.

Estes dados apontam para um possível envolvimento das proteínas do sistema complemento na ativação dos PMN. Entretanto, experimentos com leptospiras pré-incubadas com soros depletados de $\mathrm{C} 3, \mathrm{C} 5$ ou de $\mathrm{FH}$ não mostraram diferença na ativação de PMN (Figura 52A e 52B). Atribuímos este fato a possibilidade das proteínas do sistema complemento presentes nos soros depletados terem perdido parcialmente sua capacidade de ativação, durante as etapas de purificações cromatográficas do processo de depleção. Entretanto, os resultados empregando diferentes proteínas purificadas do sistema complemento como possíveis ativadoras de PMN mostraram a importância da molécula de iC3b na ativação dos PMN (Figura 53A e 53B), já que os tratamentos onde estava presente $\mathrm{C} 3 \mathrm{~b}$ ou iC3b, foram os que melhor ativaram os $\mathrm{PMN}(\mathrm{C} 3 \mathrm{~b}+\mathrm{FH}+\mathrm{FI})(\mathrm{FH}+\mathrm{C} 3 b)$. Apesar disso, as leptospiras pré-incubadas com FH não apresentaram uma vantagem para ativação dos PMN, demonstrando que ativação de PMN por leptospira é principalmente dependente de iC3b e não de FH. Nós também observamos que leptospiras não patogênicas ativam mais os PMN na presença de SHN, gerando uma quantidade maior de ROS, enquanto leptospiras patogênicas conseguem regular a deposição de iC3b na membrana, graças à sua interação com FH, fazendo com que os neutrófilos sejam menos ativados. Então, nossos resultados demonstram que, apesar de FH interagir com CR3, esta interação não contribui para o desencadeamento das atividades microbicidas dos PMN representada pela geração de ROS. A produção de ROS é dependente de iC3b. Estes resultados diferem daqueles apresentados por Losse et al. (2010) que observaram que FH ligado a C. albicans promove a geração de ROS. $\mathrm{Na}$ infecção por leptospira o papel de FH é principalmente como regulador da ativação do sistema complemento e consequentemente da deposição de C3b e iC $3 b$. Alguns experimentos ainda precisam ser feitos para determinar o papel de FH na fagocitose.

Por fim, acreditamos que o entendimento e a caracterização da interação desta família de proteínas Lig com moléculas reguladoras do sistema complemento, notadamente com FH, C4BP e com outras moléculas do hospedeiro, como PLG, possa contribuir para a compreensão das estratégias de escape utilizadas por leptospiras durante a infecção. A identificação de receptores bacterianos envolvidos nesses processos é de grande importância, 
uma vez que representam alvos interessantes para uma intervenção terapêutica contra a leptospirose. 


\section{CONCLUSÕES}

Neste estudo nós demostramos que leptospiras patogênicas (L. interrongas) além de interagir com FH e FHL-1, também interagem com FHR-1. Dentre as proteínas recombinantes de leptostospiras patogênicas empregadas neste estudo, nós mostramos que as proteínas LigA, LigB interagem com as proteínas reguladoras do complemento FH, FHL-1, FHR-1 e C4BP.

Nossos resultados sugerem que não há competição entre FH e C4BP pelo mesmo sítio de ligação às proteínas Ligs. Com tudo, FH e C4BP mesmo quando ligados nas proteínas Lig continuam sendo funcionalmente ativos, atuando como co-fatores do FI na clivagem de C3b e $\mathrm{C} 4 \mathrm{~b}$ respectivamente. Estas observações sugerem fortemente que as leptospiras podem usar este mecanismo para escapar do sistema Complemento. Alem disso, a aquisição de FH pela Leptospira interrogans favorece sua sobrevida na presença de soro humano. Nós concluímos que a sobrevida desta bactéria é diretamente proporcional à concentração sérica de FH.

Nós também confirmamos que as proteínas Lig são importantes para a sobrevida da bactéria, uma vez que a expressão das proteínas LigA ou LigB conseguiram aumentar a sobrevida de bactérias não patogênicas como demostrado nos expereimentos empregando leptospiras transgênicas (L. biflexa transgênica para LigA ou LigB). As proteínas Ligs regulam a deposição de fragmentos C3 e MAC na membrana da bactéria.

A interação da proteína LigBC com FH é principalmente mediada pelos domínios SCRs 5-7e SCRs 15-20. Nós também demostramos que plasminogênio ligado às proteínas LigAC, LigBC e LigBN é convertido em plasmina, responsável pela clivagem de C3b e C5, constituindo um novo mecanismo de evasão ao complemento empregado pelas leptospiras patogênicas. Porém, As interações entre plasminogênio e as proteínas Lig são afetadas por força iônica e mediadas por resíduos de lisina. Nós também demostramos que não há competição entre as plasminogênio e FH ou C4BP por sítios de ligação nas proteínas Lig.

Nós também concluímos que leptospiras não patogênicas ativam melhor os PMN que leptospiras patogênicas e esta activação é consideravelmente aumentada na presença de complemento. Nós demostramos que a principal molécula do sistema complemento, que interage com leptospira, e contribui para a tivação dos neutrófilos é iC3b. A interação de FH com os neutrófilos não é relevante para a ativação dos mesmos, porém sua função como cofator do FI para degradação de C3 é realemente importante, uma vez que bloqueia a ativação do complemento pelas três vias e inibe o deposito de opsoninas importantes para o processo fagocítico e atividade microbicida dos fagócitos. 
Por fim, nós concluímos que a interação desta família de proteínas Lig com moléculas reguladoras do sistema complemento e plasminogênio constituem fortes mecanismos de evasão a morte por complemento e acreditamos os resultados aqui apresentados possam contribuir a compreensão das múltiplas estratégias de evasão empregadas pelas leptospiras durante a infecção do hospedeiro e consequentemente para o entendimento da doença, assim como no desenvolvimento de novas estratégias terapéuticas. 


\section{REFERÊNCIAS ${ }^{*}$}

Adler B, de la Peña Moctezuma A. Leptospira and leptospirosis. Vet Microbiol. 2010;140(34):287-96.

Agarwal S, Ram S, Ngampasutadol J, Gulati S, Zipfel PF, Rice PA. Factor H facilitates adherence of Neisseria gonorrhoeae to complement receptor 3 on eukaryotic cells. J Immunol. 2010 Oct 1;185(7):4344-53.

Amara U, Flierl MA, Rittirsch D, Klos A, Chen H, Acker B, Brückner UB, Nilsson B, Gebhard F, Lambris JD, Huber-Lang M. Molecular intercommunication between the complement and coagulation systems. J Immunol. 2010 Nov 1;185(9):5628-36.

Amara U, Rittirsch D, Flierl M, Bruckner U, Klos A, Gebhard F, Lambris JD, Huber-Lang M. Interaction between the coagulation and complement system. Adv Exp Med Biol. 2008;632:71-9.

Anderson DL, Johnson RC. Electron microscopy of immune disruption of leptospires: action of complement and lysozyme. J Bacteriol. 1968 Jun;95(6):2293-309.

Atzingen MV, Barbosa AS, De Brito T, Vasconcellos SA, de Morais ZM, Lima DM, Abreu PA, Nascimento AL. Lsa21, a novel leptospiral protein binding adhesive matrix molecules and present during human infection. BMC Microbiol. 2008 Apr 29;8:70.

Ballard SA, Williamson M, Adler B, Vinh T, Faine S. Interactions of virulent and avirulent leptospires with primary cultures of renal epithelial cells. J Med Microbiol. 1986 Feb;21(1):59-67.

Barbosa AS, Abreu PA, Neves FO, Atzingen MV, Watanabe MM, Vieira ML, Morais ZM, Vasconcellos SA, Nascimento AL. A newly identified leptospiral adhesin mediates attachment to laminin. Infect Immun. 2006 Nov;74(11):6356-64.

Barbosa AS, Abreu PA, Vasconcellos SA, Morais ZM, Gonçales AP, Silva AS, Daha MR, Isaac L. Immune evasion of leptospira species by acquisition of human complement regulator C4BP. Infect Immun. 2009 Mar;77(3):1137-43.

Barbosa AS, Monaris D, Silva LB, Morais ZM, Vasconcellos SA, Cianciarullo AM, Isaac L, Abreu PA. Functional characterization of LcpA, a surface-exposed protein of Leptospira spp. that binds the human complement regulator C4BP. Infect Immun. 2010 Jul;78(7):3207-16.

Barnum SR. C4b-binding protein, a regulatory protein of complement. Immunol Res. 1991;10(1):28-42.

\footnotetext{
*De acordo com:

Internatonal Commitee of Medical Journal Editors. Uniform requirements for manuscripts submited to biomedical journals. [2011 July 15]. Available from:http://www.nlm.nih.gov/bsd/uniform_requirements.html.
} 
Barthel D, Schindler S, Zipfel PF. Plasminogen is a complement inhibitor. J Biol Chem. 2012 May 25;287(22):18831-42.

Bergmann S, Hammerschmidt S. Fibrinolysis and host response in bacterial infections. Thromb Haemost. 2007 Sep;98(3):512-20.

Bharti AR, Nally JE, Ricaldi JN, Matthias MA, Diaz MM, Lovett MA, Levett PN, Gilman RH, Willig MR, Gotuzzo E, Vinetz JM; Peru-United States Leptospirosis Consortium. Leptospirosis: a zoonotic disease of global importance. Lancet Infect Dis. 2003 Dec;3(12):757-71.

Bhattacharya S, Ploplis VA, Castellino FJ. Bacterial plasminogen receptors utilize host plasminogen system for effective invasion and dissemination. $\mathbf{J}$ Biomed Biotechnol. 2012;2012:482096.

Blom AM, Villoutreix BO, Dahlbäck B. Functions of human complement inhibitor C4b binding protein in relation to its structure. Arch Immunol Ther Exp (Warsz). 2004 Mar Apr;52(2):83-95.

Bradford MM. A rapid and sensitive method for the quantitation of microgram quantities of protein utilizing the principle of protein-dye binding. Anal Biochem. 1976 May 7;72:248-54.

Breiner DD, Fahey M, Salvador R, Novakova J, Coburn J. Leptospira interrogans binds to human cell surface receptors including proteoglycans. Infect Immun. 2009 Dec;77(12):5528 36.

Brenner DJ, Kaufmann AF, Sulzer KR, Steigerwalt AG, Rogers FC, Weyant RS. Further determination of DNA relatedness between serogroups and serovars in the family Leptospiraceae with a proposal for Leptospira alexanderi sp. nov. and four new Leptospira genomospecies. Int J Syst Bacteriol. 1999 Apr;49 Pt 2:839-58.

Bulach DM, Zuerner RL, Wilson P, Seemann T, McGrath A, Cullen PA, Davis J, Johnson M, Kuczek E, Alt DP, Peterson-Burch B, Coppel RL, Rood JI, Davies JK, Adler B. Genome reduction in Leptospira borgpetersenii reflects limited transmission potential. Proc Natl Acad Sci U S A. 2006 Sep 26;103(39):14560-5.

Carvalho E, Barbosa AS, Gómez RM, Cianciarullo AM, Hauk P, Abreu PA, Fiorini LC, Oliveira ML, Romero EC, Gonçales AP, Morais ZM, Vasconcellos SA, Ho PL. Leptospiral TlyC is an extracellular matrix-binding protein and does not present hemolysin activity. FEBS Lett. 2009 Apr 17;583(8):1381-5.

Castiblanco-Valencia MM, Fraga TR, Silva LB, Monaris D, Abreu PA, Strobel S, Józsi M, Isaac L, Barbosa AS. Leptospiral immunoglobulin-like proteins interact with human complement regulators factor H, FHL-1, FHR-1, and C4BP. J Infect Dis. 2012 Mar 15;205(6):995-1004.

Chou LF, Chen YT, Lu CW, Ko YC, Tang CY, Pan MJ, Tian YC, Chiu CH, Hung CC, Yang $\mathrm{CW}$. Sequence of Leptospira santarosai serovar Shermani genome and prediction of virulence-associated genes. Gene. 2012 Dec 15;511(2):364-70. 
Choy HA, Kelley MM, Chen TL, Møller AK, Matsunaga J, Haake DA. Physiological osmotic induction of Leptospira interrogans adhesion: LigA and LigB bind extracellular matrix proteins and fibrinogen. Infect Immun. 2007 May;75(5):2441-50.

Chung MC, Tonry JH, Narayanan A, Manes NP, Mackie RS, Gutting B, Mukherjee DV, Popova TG, Kashanchi F, Bailey CL, Popov SG. Bacillus anthracis interacts with plasmin(ogen) to evade C3b-dependent innate immunity. PLoS One. 2011 Mar 25;6(3):e18119.

Cinco M, Banfi E. Activation of complement by leptospires and its bactericidal activity. Zentralbl Bakteriol Mikrobiol Hyg A. 1983 Apr;254(2):261-5.

Cinco M, Cini B, Perticarari S, Presani G. Leptospira interrogans binds to the CR3 receptor on mammalian cells. Microb Pathog. 2002 Dec;33(6):299-305.

Coleman JL, Benach JL. Use of the plasminogen activation system by microorganisms. J Lab Clin Med. 1999 Dec;134(6):567-76.

Coleman JL, Gebbia JA, Piesman J, Degen JL, Bugge TH, Benach JL. Plasminogen is required for efficient dissemination of $\mathrm{B}$. burgdorferi in ticks and for enhancement of spirochetemia in mice. Cell. 1997 Jun 27;89(7):1111-9.

Coleman JL, Sellati TJ, Testa JE, Kew RR, Furie MB, Benach JL. Borrelia burgdorferi binds plasminogen, resulting in enhanced penetration of endothelial monolayers. Infect Immun. $1995 \mathrm{Jul} ; 63(7): 2478-84$.

Collen D. Staphylokinase: a potent, uniquely fibrin-selective thrombolytic agent. Nat Med. 1998 Mar;4(3):279-84.

Collen D. The plasminogen (fibrinolytic) system. Thromb Haemost. 1999 Aug;82(2):259-70.

Cooper NR. Complement evasion strategies of microorganisms. Immunol Today. 1991 Sep;12(9):327-31.

Croda J, Figueira CP, Wunder EA Jr, Santos CS, Reis MG, Ko AI, Picardeau M. Targeted mutagenesis in pathogenic Leptospira species: disruption of the LigB gene does not affect virulence in animal models of leptospirosis. Infect Immun. 2008 Dec;76(12):5826-33.

Da Silva CM, de Abreu Vidipó L, Nishi R, Cristina Plotkowski M. Binding of plasminogen to Pseudomonas aeruginosa results in formation of surface-associated plasmin and enhanced bacterial invasiveness. Microb Pathog. 2004 Feb;36(2):59-66.

De Paula PF, Barbosa JE, Junior PR, Ferriani VP, Latorre MR, Nudelman V, Isaac L. Ontogeny of complement regulatory proteins - concentrations of factor $\mathrm{h}$, factor I, $\mathrm{c} 4 \mathrm{~b}$ binding protein, properdin and vitronectin in healthy children of different ages and in adults. Scand $\mathbf{J}$ Immunol. 2003 Nov;58(5):572-7.

Dempsey PW, Allison ME, Akkaraju S, Goodnow CC, Fearon DT. C3d of complement as a molecular adjuvant: bridging innate and acquired immunity. Science. 1996 Jan 19;271(5247):348-50. 
DiScipio RG, Daffern PJ, Schraufstätter IU, Sriramarao P. Human polymorphonuclear leukocytes adhere to complement factor $\mathrm{H}$ through an interaction that involves alphaMbeta2 (CD11b/CD18). J Immunol. 1998 Apr 15;160(8):4057-66.

Domingos RF, Vieira ML, Romero EC, Gonçales AP, de Morais ZM, Vasconcellos SA, Nascimento AL. Features of two proteins of Leptospira interrogans with potential role in host-pathogen interactions. BMC Microbiol. 2012 Mar 30;12:50.

Dunkelberger JR, Song WC. Complement and its role in innate and adaptive immune responses. Cell Res. 2010 Jan;20(1):34-50.

Estaller C, Schwaeble W, Dierich M, Weiss EH. Human complement factor H: two factor H proteins are derived from alternatively spliced transcripts. Eur J Immunol. 1991 Mar;21(3):799-802.

Evangelista KV, Coburn J. Leptospira as an emerging pathogen: a review of its biology, pathogenesis and host immune responses. Future Microbiol. 2010 Sep;5(9):1413-25.

Faine S, Adler B, Bolin C, Perolat P. Leptospira and leptospirosis. 2nd. ed. Melbourne: MediSci; 1999. 296 p.

Faisal SM, Yan W, Chen CS, Palaniappan RU, McDonough SP, Chang YF. Evaluation of protective immunity of Leptospira immunoglobulin like protein A (LigA) DNA vaccine against challenge in hamsters. Vaccine. 2008 Jan 10;26(2):277-87.

Faisal SM, Yan W, McDonough SP, Chang YF. Leptospira immunoglobulin-like protein A variable region (LigAvar) incorporated in liposomes and PLGA microspheres produces a robust immune response correlating to protective immunity. Vaccine. 2009 Jan 14;27(3):378 87.

Fernandes LG, Vieira ML, Alves IJ, de Morais ZM, Vasconcellos SA, Romero EC, Nascimento AL. Functional and immunological evaluation of two novel proteins of Leptospira spp. Microbiology. 2014 Jan;160(Pt 1):149-64.

Fernandes LG, Vieira ML, Kirchgatter K, Alves IJ, de Morais ZM, Vasconcellos SA, Romero EC, Nascimento AL. OmpL1 is an extracellular matrix- and plasminogen-interacting protein of Leptospira spp. Infect Immun. 2012 Oct;80(10):3679-92.

Ferreira VP, Pangburn MK, Cortés C. Complement control protein factor H: the good, the bad, and the inadequate. Mol Immunol. 2010 Aug;47(13):2187-97.

Figueira CP, Croda J, Choy HA, Haake DA, Reis MG, Ko AI, Picardeau M. Heterologous expression of pathogen-specific genes ligA and ligB in the saprophyte Leptospira biflexa confers enhanced adhesion to cultured cells and fibronectin. BMC Microbiol. 2011 Jun $9 ; 11: 129$.

Fraga TR, Barbosa AS, Isaac L. Leptospirosis: aspects of innate immunity, immunopathogenesis and immune evasion from the complement system. Scand J Immunol. 2011 May;73(5):408-19. 
Fraga TR, Courrol Ddos S, Castiblanco-Valencia MM, Hirata IY, Vasconcellos SA, Juliano L, Barbosa AS, Isaac L. Immune evasion by pathogenic Leptospira strains: the secretion of proteases that directly cleave complement proteins. J Infect Dis. 2014 Mar;209(6):876-86.

Fuchs H, Simon MM, Wallich R, Bechtel M, Kramer MD. Borrelia burgdorferi induces secretion of pro-urokinase-type plasminogen activator by human monocytes. Infect Immun. 1996 Oct;64(10):4307-12.

Fuchs H, Wallich R, Simon MM, Kramer MD. The outer surface protein A of the spirochete Borrelia burgdorferi is a plasmin(ogen) receptor. Proc Natl Acad Sci U S A. 1994 Dec 20;91(26):12594-8.

Gamberini M, Gómez RM, Atzingen MV, Martins EA, Vasconcellos SA, Romero EC, Leite LC, Ho PL, Nascimento AL. Whole-genome analysis of Leptospira interrogans to identify potential vaccine candidates against leptospirosis. FEMS Microbiol Lett. 2005 Mar $15 ; 244(2): 305-13$.

Gigli I, Sorvillo J, Halbwachs-Mecarelli L. Regulation and deregulation of the fluid-phase classical pathway C3 convertase. J Immunol. 1985 Jul;135(1):440-4.

Goris MG, Wagenaar JF, Hartskeerl RA, van Gorp EC, Schuller S, Monahan AM, Nally JE, van der Poll T, van 't Veer C. Potent innate immune response to pathogenic leptospira in human whole blood. PLoS One. 2011 Mar 31;6(3):e18279.

Gouveia EL, Metcalfe J, de Carvalho AL, Aires TS, Villasboas-Bisneto JC, Queirroz A, Santos AC, Salgado K, Reis MG, Ko AI. Leptospirosis-associated severe pulmonary hemorrhagic syndrome, Salvador, Brazil. Emerg Infect Dis. 2008 Mar;14(3):505-8.

Grab DJ, Perides G, Dumler JS, Kim KJ, Park J, Kim YV, Nikolskaia O, Choi KS, Stins MF, Kim KS. Borrelia burgdorferi, host-derived proteases, and the blood-brain barrier. Infect Immun. 2005 Feb;73(2):1014-22.

Haake DA, Chao G, Zuerner RL, Barnett JK, Barnett D, Mazel M, Matsunaga J, Levett PN, Bolin CA. The leptospiral major outer membrane protein LipL32 is a lipoprotein expressed during mammalian infection. Infect Immun. 2000 Apr;68(4):2276-85.

Hauk P, Macedo F, Romero EC, Vasconcellos SA, de Morais ZM, Barbosa AS, Ho PL. In LipL32, the major leptospiral lipoprotein, the $\mathrm{C}$ terminus is the primary immunogenic domain and mediates interaction with collagen IV and plasma fibronectin. Infect Immun. 2008 Jun;76(6):2642-50.

Heinen S, Hartmann A, Lauer N, Wiehl U, Dahse HM, Schirmer S, Gropp K, Enghardt T, Wallich R, Hälbich S, Mihlan M, Schlötzer-Schrehardt U, Zipfel PF, Skerka C. Factor H related protein 1 (CFHR-1) inhibits complement C5 convertase activity and terminal complex formation. Blood. 2009 Sep 17;114(12):2439-47.

Hellwage J, Jokiranta TS, Koistinen V, Vaarala O, Meri S, Zipfel PF. Functional properties of complement factor H-related proteins FHR-3 and FHR-4: binding to the C3d region of C3b and differential regulation by heparin. FEBS Lett. 1999 Dec 3;462(3):345-52. 
Horstmann RD, Sievertsen HJ, Leippe M, Fischetti VA. Role of fibrinogen in complement inhibition by streptococcal M protein. Infect Immun. 1992 Dec;60(12):5036-41.

Ito T, Yanagawa R. Leptospiral attachment to four structural components of extracellular matrix. Nihon Juigaku Zasshi. 1987 Oct;49(5):875-82.

Johnson RC, Harris VG. Antileptospiral activity of serum. II. Leptospiral virulence factor. J Bacteriol. 1967 Feb;93(2):513-9.

Johnson RC, Muschel LH. Antileptospiral activity of serum. I. Normal and immune serum. J Bacteriol. 1966 Apr;91(4):1403-9.

Józsi M, Zipfel PF. Factor H family proteins and human diseases. Trends Immunol. 2008 Aug;29(8):380-7.

Kitaoka M, Inoue S. Standard procedures of Weil's disease vaccine and Weil's disease and Akiyami combined vaccine (Japanese in original). Jpn Med J 1952;1478:2845-7.

Klempner MS, Noring R, Epstein MP, McCloud B, Hu R, Limentani SA, Rogers RA. Binding of human plasminogen and urokinase-type plasminogen activator to the Lyme disease spirochete, Borrelia burgdorferi. J Infect Dis. 1995 May;171(5):1258-65.

Klempner MS, Noring R, Epstein MP, McCloud B, Rogers RA. Binding of human urokinase type plasminogen activator and plasminogen to Borrelia species. J Infect Dis. 1996 Jul;174(1):97-104.

Ko AI, Goarant C, Picardeau M. Leptospira: the dawn of the molecular genetics era for an emerging zoonotic pathogen. Nat Rev Microbiol. 2009 Oct;7(10):736-47.

Köhl J. Self, non-self, and danger: a complementary view. Adv Exp Med Biol. 2006;586:71 94.

Koizumi N, Watanabe $\mathrm{H}$. Leptospiral immunoglobulin-like proteins elicit protective immunity. Vaccine. 2004 Mar 29;22(11-12):1545-52.

Koizumi N, Watanabe H. Leptospirosis vaccines: past, present, and future. J Postgrad Med. 2005 Jul-Sep;51(3):210-4.

Koizumi N, Watanabe H. Molecular cloning and characterization of a novel leptospiral lipoprotein with OmpA domain.

Kraiczy P, Hartmann K, Hellwage J, Skerka C, Kirschfink M, Brade V, Zipfel PF, Wallich R, Stevenson B. Immunological characterization of the complement regulator factor H-binding CRASP and Erp proteins of Borrelia burgdorferi. Int J Med Microbiol. 2004 Apr;293 Suppl 37:152-7.

Kühn S, Skerka C, Zipfel PF. Mapping of the complement regulatory domains in the human factor H-like protein 1 and in factor H1. J Immunol. 1995 Dec 15;155(12):5663-70. 
Kunert A, Losse J, Gruszin C, Hühn M, Kaendler K, Mikkat S, Volke D, Hoffmann R, Jokiranta TS, Seeberger H, Moellmann U, Hellwage J, Zipfel PF. Immune evasion of the human pathogen Pseudomonas aeruginosa: elongation factor Tuf is a factor $\mathrm{H}$ and plasminogen binding protein. J Immunol. 2007 Sep 1;179(5):2979-88.

Lähteenmäki K, Kuusela P, Korhonen TK. Bacterial plasminogen activators and receptors. FEMS Microbiol Rev. 2001 Dec;25(5):531-52.

Lee SH, Kim KA, Park YG, Seong IW, Kim MJ, Lee YJ. Identification and partial characterization of a novel hemolysin from Leptospira interrogans serovar lai. Gene. 2000 Aug 22;254(1-2):19-28.

Levett PN, Morey RE, Galloway R, Steigerwalt AG, Ellis WA. Reclassification of Leptospira parva Hovind-Hougen et al. 1982 as Turneriella parva gen. nov., comb. nov. Int J Syst Evol Microbiol. 2005 Jul;55(Pt 4):1497-9.

Levett PN. Leptospirosis. Clin Microbiol Rev. 2001 Apr;14(2):296-326. Liao S, Sun A, Ojcius DM, Wu S, Zhao J, Yan J. Inactivation of the fliY gene encoding a flagellar motor switch protein attenuates mobility and virulence of Leptospira interrogans strain Lai. BMC Microbiol. 2009 Dec 9;9:253.

Lin YP, Chang YF. A domain of the Leptospira LigB contributes to high affinity binding of fibronectin. Biochem Biophys Res Commun. 2007 Oct 19;362(2):443-8.

Lin YP, Chang YF. The C-terminal variable domain of LigB from Leptospira mediates binding to fibronectin. J Vet Sci. 2008 Jun;9(2):133-44.

Lin YP, Greenwood A, Nicholson LK, Sharma Y, McDonough SP, Chang YF. Fibronectin binds to and induces conformational change in a disordered region of leptospiral immunoglobulin-like protein B. J Biol Chem. 2009 Aug 28;284(35):23547-57.

Lin YP, Greenwood A, Yan W, Nicholson LK, Sharma Y, McDonough SP, Chang YF. A novel fibronectin type III module binding motif identified on C-terminus of Leptospira immunoglobulin-like protein, LigB. Biochem Biophys Res Commun. 2009 Nov 6;389(1):57 62.

Lin YP, Lee DW, McDonough SP, Nicholson LK, Sharma Y, Chang YF. Repeated domains of leptospira immunoglobulin-like proteins interact with elastin and tropoelastin. J Biol Chem. 2009 Jul 17;284(29):19380-91.

Lin YP, McDonough SP, Sharma Y, Chang YF. The terminal immunoglobulin-like repeats of LigA and LigB of Leptospira enhance their binding to gelatin binding domain of fibronectin and host cells. PLoS One. 2010 Jun 24;5(6):e11301.

Lin YP, Raman R, Sharma Y, Chang YF. Calcium binds to leptospiral immunoglobulin-like protein, LigB, and modulates fibronectin binding. J Biol Chem. 2008 Sep 12;283(37):25140 9.

Lindahl G, Sjöbring U, Johnsson E. Human complement regulators: a major target for pathogenic microorganisms. Curr Opin Immunol. 2000 Feb;12(1):44-51. 
Liu Y, Zheng W, Li L, Mao Y, Yan J. Pathogenesis of leptospirosis: interaction of Leptospira interrogans with in vitro cultured mammalian cells. Med Microbiol Immunol. 2007 Dec;196(4):233-9.

Losse J, Zipfel PF, Józsi M. Factor $\mathrm{H}$ and factor $\mathrm{H}$-related protein 1 bind to human neutrophils via complement receptor 3, mediate attachment to Candida albicans, and enhance neutrophil antimicrobial activity. J Immunol. 2010 Jan 15;184(2):912-21.

Manuelian T, Hellwage J, Meri S, Caprioli J, Noris M, Heinen S, Jozsi M, Neumann HP, Remuzzi G, Zipfel PF. Mutations in factor $\mathrm{H}$ reduce binding affinity to $\mathrm{C} 3 \mathrm{~b}$ and heparin and surface attachment to endothelial cells in hemolytic uremic syndrome. J Clin Invest. 2003 Apr;111(8):1181-90.

Marston FA. The purification of eukaryotic polypeptides synthesized in Escherichia coli. Biochem J. 1986 Nov 15;240(1):1-12.

Martínez R, Pérez A, Quiñones Mdel C, Cruz R, Alvarez A, Armesto M, Fernández C, Menéndez J, Rodríguez I, Baró M, Díaz M, Rodríguez J, Sierra G, Obregón AM, Toledo ME, Fernández N. [Efficacy and safety of a vaccine against human leptospirosis in Cuba]. Rev Panam Salud Publica. 2004 Apr;15(4):249-55.

Matsunaga J, Barocchi MA, Croda J, Young TA, Sanchez Y, Siqueira I, Bolin CA, Reis MG, Riley LW, Haake DA, Ko AI. Pathogenic Leptospira species express surface-exposed proteins belonging to the bacterial immunoglobulin superfamily. Mol Microbiol. 2003 Aug;49(4):929-45.

Matsunaga J, Sanchez Y, Xu X, Haake DA. Osmolarity, a key environmental signal controlling expression of leptospiral proteins LigA and LigB and the extracellular release of LigA. Infect Immun. 2005 Jan;73(1):70-8.

McRae JL, Duthy TG, Griggs KM, Ormsby RJ, Cowan PJ, Cromer BA, McKinstry WJ, Parker MW, Murphy BF, Gordon DL. Human factor H-related protein 5 has cofactor activity, inhibits C3 convertase activity, binds heparin and C-reactive protein, and associates with lipoprotein. J Immunol. 2005 May 15;174(10):6250-6.

Medzhitov R, Janeway C Jr. Innate immunity. N Engl J Med. 2000 Aug 3;343(5):338-44.

Mendes RS, Von Atzingen M, de Morais ZM, Gonçales AP, Serrano SM, Asega AF, Romero EC, Vasconcellos SA, Nascimento AL. The novel leptospiral surface adhesin Lsa20 binds laminin and human plasminogen and is probably expressed during infection. Infect Immun. 2011 Nov;79(11):4657-67.

Meri S. Loss of self-control in the complement system and innate autoreactivity. Ann N Y Acad Sci. 2007 Aug;1109:93-105.

Meri T, Blom AM, Hartmann A, Lenk D, Meri S, Zipfel PF. The hyphal and yeast forms of Candida albicans bind the complement regulator C4b-binding protein. Infect Immun. 2004 Nov;72(11):6633-41. 
Meri T, Cutler SJ, Blom AM, Meri S, Jokiranta TS. Relapsing fever spirochetes Borrelia recurrentis and $\mathrm{B}$. duttonii acquire complement regulators $\mathrm{C} 4 \mathrm{~b}$-binding protein and factor $\mathrm{H}$. Infect Immun. $2006 \mathrm{Jul} ; 74(7): 4157-63$.

Meri T, Hartmann A, Lenk D, Eck R, Würzner R, Hellwage J, Meri S, Zipfel PF. The yeast Candida albicans binds complement regulators factor $\mathrm{H}$ and FHL-1. Infect Immun. 2002 Sep;70(9):5185-92.

Meri T, Murgia R, Stefanel P, Meri S, Cinco M. Regulation of complement activation at the C3-level by serum resistant leptospires. Microb Pathog. 2005 Oct;39(4):139-47.

Merien F, Amouriaux P, Perolat P, Baranton G, Saint Girons I. Polymerase chain reaction for detection of Leptospira spp. in clinical samples. J Clin Microbiol. 1992 Sep;30(9):2219-24.

Merien F, Baranton G, Perolat P. Invasion of Vero cells and induction of apoptosis in macrophages by pathogenic Leptospira interrogans are correlated with virulence. Infect Immun. 1997 Feb;65(2):729-38.

Merien F, Truccolo J, Baranton G, Perolat P. Identification of a 36-kDa fibronectin-binding protein expressed by a virulent variant of Leptospira interrogans serovar icterohaemorrhagiae. FEMS Microbiol Lett. 2000 Apr 1;185(1):17-22.

Miller DP, Bell JK, McDowell JV, Conrad DH, Burgner JW, Héroux A, Marconi RT. Structure of factor H-binding protein $\mathrm{B}(\mathrm{FhbB})$ of the periopathogen, Treponema denticola: insights into progression of periodontal disease. J Biol Chem. 2012 Apr 13;287(16):12715-22.

Misasi R, Huemer HP, Schwaeble W, Sölder E, Larcher C, Dierich MP. Human complement factor $\mathrm{H}$ : an additional gene product of $43 \mathrm{kDa}$ isolated from human plasma shows cofactor activity for the cleavage of the third component of complement. Eur J Immunol. 1989 Sep;19(9):1765-8.

Mölkänen T, Tyynelä J, Helin J, Kalkkinen N, Kuusela P. Enhanced activation of bound plasminogen on Staphylococcus aureus by staphylokinase.

Morgan BP, Harris CL. Complement regulatory proteins. San Diego: Academic Press; 1999. $382 \mathrm{p}$.

Murray GL, Srikram A, Henry R, Hartskeerl RA, Sermswan RW, Adler B. Mutations affecting Leptospira interrogans lipopolysaccharide attenuate virulence. Mol Microbiol. 2010 Nov;78(3):701-9.

Murray GL, Srikram A, Henry R, Puapairoj A, Sermswan RW, Adler B. Leptospira interrogans requires heme oxygenase for disease pathogenesis. Microbes Infect. 2009 Feb;11(2):311-4.

Nahori MA, Fournié-Amazouz E, Que-Gewirth NS, Balloy V, Chignard M, Raetz CR, Saint Girons I, Werts C. Differential TLR recognition of leptospiral lipid A and lipopolysaccharide in murine and human cells. J Immunol. 2005 Nov 1;175(9):6022-31. 
Nakai K, Kanehisa M. Expert system for predicting protein localization sites in gram-negative bacteria. Proteins. 1991;11(2):95-110.

Nascimento AL, Ko AI, Martins EA, Monteiro-Vitorello CB, Ho PL, Haake DA, Verjovski Almeida S, Hartskeerl RA, Marques MV, Oliveira MC, Menck CF, Leite LC, Carrer H, Coutinho LL, Degrave WM, Dellagostin OA, El-Dorry H, Ferro ES, Ferro MI, Furlan LR, Gamberini M, Giglioti EA, Góes-Neto A, Goldman GH, Goldman MH, Harakava R, Jerônimo SM, Junqueira-de-Azevedo IL, Kimura ET, Kuramae EE, Lemos EG, Lemos MV, Marino CL, Nunes LR, de Oliveira RC, Pereira GG, Reis MS, Schriefer A, Siqueira WJ, Sommer P, Tsai SM, Simpson AJ, Ferro JA, Camargo LE, Kitajima JP, Setubal JC, Van Sluys MA. Comparative genomics of two Leptospira interrogans serovars reveals novel insights into physiology and pathogenesis. J Bacteriol. 2004 Apr;186(7):2164-72.

Nascimento AL, Verjovski-Almeida S, Van Sluys MA, Monteiro-Vitorello CB, Camargo LE, Digiampietri LA, Harstkeerl RA, Ho PL, Marques MV, Oliveira MC, Setubal JC, Haake DA, Martins EA. Genome features of Leptospira interrogans serovar Copenhageni. Braz J Med Biol Res. 2004 Apr;37(4):459-77.

Nogueira SV, Backstedt BT, Smith AA, Qin JH, Wunder EA Jr, Ko A, Pal U. Leptospira interrogans enolase is secreted extracellularly and interacts with plasminogen. PLoS One. 2013 Oct 18;8(10):e78150.

Nordstrand A, Shamaei-Tousi A, Ny A, Bergström S. Delayed invasion of the kidney and brain by Borrelia crocidurae in plasminogen-deficient mice. Infect Immun. 2001 Sep;69(9):5832-9.

Oikonomopoulou K, Ricklin D, Ward PA, Lambris JD. Interactions between coagulation and complement--their role in inflammation. Semin Immunopathol. 2012 Jan;34(1):151-65.

Oliveira R, de Morais ZM, Gonçales AP, Romero EC, Vasconcellos SA, Nascimento AL. Characterization of novel OmpA-like protein of Leptospira interrogans that binds extracellular matrix molecules and plasminogen. PLoS One. 2011;6(7):e21962.

Oppermann M, Manuelian T, Józsi M, Brandt E, Jokiranta TS, Heinen S, Meri S, Skerka C, Götze O, Zipfel PF. The C-terminus of complement regulator Factor $\mathrm{H}$ mediates target recognition: evidence for a compact conformation of the native protein. Clin Exp Immunol. 2006 May;144(2):342-52.

Palaniappan RU, Chang YF, Hassan F, McDonough SP, Pough M, Barr SC, Simpson KW, Mohammed HO, Shin S, McDonough P, Zuerner RL, Qu J, Roe B. Expression of leptospiral immunoglobulin-like protein by Leptospira interrogans and evaluation of its diagnostic potential in a kinetic ELISA. J Med Microbiol. 2004 Oct;53(Pt 10):975-84.

Palaniappan RU, Chang YF, Jusuf SS, Artiushin S, Timoney JF, McDonough SP, Barr SC, Divers TJ, Simpson KW, McDonough PL, Mohammed HO. Cloning and molecular characterization of an immunogenic LigA protein of Leptospira interrogans. Infect Immun. 2002 Nov;70(11):5924-30. 
Palaniappan RU, McDonough SP, Divers TJ, Chen CS, Pan MJ, Matsumoto M, Chang YF. Immunoprotection of recombinant leptospiral immunoglobulin-like protein A against Leptospira interrogans serovar Pomona infection. Infect Immun. 2006 Mar;74(3):1745-50.

Palaniappan RU, Ramanujam S, Chang YF. Leptospirosis: pathogenesis, immunity, and diagnosis. Curr Opin Infect Dis. 2007 Jun;20(3):284-92. Review. PubMed PMID: 17471039.

Parry MA, Zhang XC, Bode I. Molecular mechanisms of plasminogen activation: bacterial cofactors provide clues. Trends Biochem Sci. 2000 Feb;25(2):53-9.

Perolat P, Chappel RJ, Adler B, Baranton G, Bulach DM, Billinghurst ML, Letocart M, Merien F, Serrano MS. Leptospira fainei sp. nov., isolated from pigs in Australia. Int J Syst Bacteriol. 1998 Jul;48 Pt 3:851-8.

Persson J, Lindahl G. Single-step purification of human C4b-binding protein (C4BP) by affinity chromatography on a peptide derived from a streptococcal surface protein. $\mathrm{J}$ Immunol Methods. 2005 Feb;297(1-2):83-95.

Picardeau M, Bulach DM, Bouchier C, Zuerner RL, Zidane N, Wilson PJ, Creno S, Kuczek ES, Bommezzadri S, Davis JC, McGrath A, Johnson MJ, Boursaux-Eude C, Seemann T, Rouy Z, Coppel RL, Rood JI, Lajus A, Davies JK, Médigue C, Adler B. Genome sequence of the saprophyte Leptospira biflexa provides insights into the evolution of Leptospira and the pathogenesis of leptospirosis. PLoS One. 2008 Feb 13;3(2):e1607.

Ramos CR, Abreu PA, Nascimento AL, Ho PL. A high-copy T7 Escherichia coli expression vector for the production of recombinant proteins with a minimal $\mathrm{N}$-terminal His-tagged fusion peptide. Braz J Med Biol Res. 2004 Aug;37(8):1103-9.

Ren SX, Fu G, Jiang XG, Zeng R, Miao YG, Xu H, Zhang YX, Xiong H, Lu G, Lu LF, Jiang HQ, Jia J, Tu YF, Jiang JX, Gu WY, Zhang YQ, Cai Z, Sheng HH, Yin HF, Zhang Y, Zhu GF, Wan M, Huang HL, Qian Z, Wang SY, Ma W, Yao ZJ, Shen Y, Qiang BQ, Xia QC, Guo XK, Danchin A, Saint Girons I, Somerville RL, Wen YM, Shi MH, Chen Z, Xu JG, Zhao GP. Unique physiological and pathogenic features of Leptospira interrogans revealed by whole genome sequencing. Nature. 2003 Apr 24;422(6934):888-93.

Ricaldi JN, Swancutt MA, Matthias MA. Current trends in translational research in leptospirosis. Curr Opin Infect Dis. 2013 Oct;26(5):399-403.

Rijken DC. Plasminogen activators and plasminogen activator inhibitors: biochemical aspects. Baillieres Clin Haematol. 1995 Jun;8(2):291-312.

Ristow P, Bourhy P, da Cruz McBride FW, Figueira CP, Huerre M, Ave P, Girons IS, Ko AI, Picardeau M. The OmpA-like protein Loa22 is essential for leptospiral virulence. PLoS Pathog. 2007 Jul;3(7):e97.

Ristow P, Bourhy P, Kerneis S, Schmitt C, Prevost MC, Lilenbaum W, Picardeau M. Biofilm formation by saprophytic and pathogenic leptospires. Microbiology. 2008 May;154(Pt 5):1309-17. 
Rodríguez de Córdoba S, Esparza-Gordillo J, Goicoechea de Jorge E, Lopez-Trascasa M, Sánchez-Corral P. The human complement factor $\mathrm{H}$ : functional roles, genetic variations and disease associations. Mol Immunol. 2004 Jun;41(4):355-67.

Rooijakkers SH, Ruyken M, Roos A, Daha MR, Presanis JS, Sim RB, van Wamel WJ, van Kessel KP, van Strijp JA. Immune evasion by a staphylococcal complement inhibitor that acts on C3 convertases. Nat Immunol. 2005 Sep;6(9):920-7.

Rooijakkers SH, van Kessel KP, van Strijp JA. Staphylococcal innate immune evasion. Trends Microbiol. 2005 Dec;13(12):596-601.

Rossmann E, Kraiczy P, Herzberger P, Skerka C, Kirschfink M, Simon MM, Zipfel PF, Wallich R. Dual binding specificity of a Borrelia hermsii-associated complement regulator acquiring surface protein for factor $\mathrm{H}$ and plasminogen discloses a putative virulence factor of relapsing fever spirochetes. J Immunol. 2007 Jun 1;178(11):7292-301.

Sakharov DV, Lijnen HR, Rijken DC. Interactions between staphylokinase, plasmin(ogen), and fibrin. Staphylokinase discriminates between free plasminogen and plasminogen bound to partially degraded fibrin. J Biol Chem. 1996 Nov 1;271(44):27912-8.

Sambrook, J., Fritsch, E. F., Maniatis, T. Molecular Cloning: a laboratory manual. 2.ed. New York: Cold Spring Harbor Laboratory Press. 1989.

Segers RP, van der Drift A, de Nijs A, Corcione P, van der Zeijst BA, Gaastra W. Molecular analysis of a sphingomyelinase $\mathrm{C}$ gene from Leptospira interrogans serovar hardjo. Infect Immun. $1990 \mathrm{Jul} ; 58(7): 2177-85$.

Setubal JC, Reis M, Matsunaga J, Haake DA. Lipoprotein computational prediction in spirochaetal genomes. Microbiology. 2006 Jan;152(Pt 1):113-21.

Silva EF, Medeiros MA, McBride AJ, Matsunaga J, Esteves GS, Ramos JG, Santos CS, Croda J, Homma A, Dellagostin OA, Haake DA, Reis MG, Ko AI. The terminal portion of leptospiral immunoglobulin-like protein LigA confers protective immunity against lethal infection in the hamster model of leptospirosis. Vaccine. 2007 Aug 14;25(33):6277-86.

Siqueira GH, Atzingen MV, Alves IJ, de Morais ZM, Vasconcellos SA, Nascimento AL. Characterization of three novel adhesins of Leptospira interrogans. Am J Trop Med Hyg. 2013 Dec;89(6):1103-16.

Skerka C, Zipfel PF. Complement factor $\mathrm{H}$ related proteins in immune diseases. Vaccine. 2008 Dec 30;26 Suppl 8:19-14.

Souza NM, Vieira ML, Alves IJ, de Morais ZM, Vasconcellos SA, Nascimento AL. Lsa30, a novel adhesin of Leptospira interrogans binds human plasminogen and the complement regulator C4bp. Microb Pathog. 2012 Sep;53(3-4):125-34.

Stevenson B, Choy HA, Pinne M, Rotondi ML, Miller MC, Demoll E, Kraiczy P, Cooley AE, Creamer TP, Suchard MA, Brissette CA, Verma A, Haake DA. Leptospira interrogans endostatin-like outer membrane proteins bind host fibronectin, laminin and regulators of complement. PLoS One. 2007 Nov 14;2(11):e1188. 
Suhonen J, Hartiala K, Tuominen-Gustafsson H, Viljanen MK. Borrelia burgdorferi-induced oxidative burst, calcium mobilization, and phagocytosis of human neutrophils are complement dependent. J Infect Dis. 2000 Jan;181(1):195-202.

Thern A, Stenberg L, Dahlbäck B, Lindahl G. Ig-binding surface proteins of Streptococcus pyogenes also bind human $\mathrm{C} 4 \mathrm{~b}$-binding protein $(\mathrm{C} 4 \mathrm{BP})$, a regulatory component of the complement system. J Immunol. 1995 Jan 1;154(1):375-86.

Thomas DD, Higbie LM. In vitro association of leptospires with host cells. Infect Immun. 1990 Mar;58(3):581-5.

Timmann C, Leippe M, Horstmann RD. Two major serum components antigenically related to complement factor $\mathrm{H}$ are different glycosylation forms of a single protein with no factor $\mathrm{H}$ like complement regulatory functions. J Immunol. 1991 Feb 15;146(4):1265-70.

Trowbridge AA, Green JB 3rd, Bonnett JD, Shohet SB, Ponnappa BD, McCombs WB 3rd. Hemolytic anemia associated with leptospirosis. Morphologic and lipid studies. Am J Clin Pathol. 1981 Oct;76(4):493-8.

Tsuchimoto M, Niikura M, Ono E, Kida H, Yanagawa R. Leptospiral attachment to cultured cells. Zentralbl Bakteriol Mikrobiol Hyg A. 1984 Dec;258(2-3):268-74.

Verma A, Brissette CA, Bowman AA, Shah ST, Zipfel PF, Stevenson B. Leptospiral endostatin-like protein $A$ is a bacterial cell surface receptor for human plasminogen. Infect Immun. 2010 May;78(5):2053-9.

Verma A, Hellwage J, Artiushin S, Zipfel PF, Kraiczy P, Timoney JF, Stevenson B. LfhA, a novel factor H-binding protein of Leptospira interrogans. Infect Immun. 2006 May;74(5):2659-66.

Vieira ML, Atzingen MV, Oliveira R, Mendes RS, Domingos RF, Vasconcellos SA, Nascimento AL. Plasminogen binding proteins and plasmin generation on the surface of Leptospira spp.: the contribution to the bacteria-host interactions. J Biomed Biotechnol. 2012;2012:758513.

Vieira ML, Atzingen MV, Oliveira TR, Oliveira R, Andrade DM, Vasconcellos SA, Nascimento AL. In vitro identification of novel plasminogen-binding receptors of the pathogen Leptospira interrogans. PLoS One. 2010 Jun 22;5(6):e11259.

Vieira ML, de Morais ZM, Vasconcellos SA, Romero EC, Nascimento AL. In vitro evidence for immune evasion activity by human plasmin associated to pathogenic Leptospira interrogans. Microb Pathog. 2011 Nov;51(5):360-5.

Vieira ML, Vasconcellos SA, Gonçales AP, de Morais ZM, Nascimento AL. Plasminogen acquisition and activation at the surface of leptospira species lead to fibronectin degradation. Infect Immun. 2009 Sep;77(9):4092-101.

Vinh T, Faine S, Adler B. Adhesion of leptospires to mouse fibroblasts (L929) and its enhancement by specific antibody. J Med Microbiol. 1984 Aug;18(1):73-85. 
Vogl G, Lesiak I, Jensen DB, Perkhofer S, Eck R, Speth C, Lass-Flörl C, Zipfel PF, Blom AM, Dierich MP, Würzner R. Immune evasion by acquisition of complement inhibitors: the mould Aspergillus binds both factor $\mathrm{H}$ and $\mathrm{C} 4 \mathrm{~b}$ binding protein. Mol Immunol. 2008 Mar;45(5):1485-93.

Wallich R, Pattathu J, Kitiratschky V, Brenner C, Zipfel PF, Brade V, Simon MM, Kraiczy P. Identification and functional characterization of complement regulator-acquiring surface protein 1 of the Lyme disease spirochetes Borrelia afzelii and Borrelia garinii. Infect Immun. 2005 Apr;73(4):2351-9.

Walport MJ. Complement. First of two parts. N Engl J Med. 2001 Apr 5;344(14):1058-66.

Wandersman C, Stojiljkovic I. Bacterial heme sources: the role of heme, hemoprotein receptors and hemophores. Curr Opin Microbiol. 2000 Apr;3(2):215-20.

Wang B, Sullivan JA, Sullivan GW, Mandell GL. Role of specific antibody in interaction of leptospires with human monocytes and monocyte-derived macrophages. Infect Immun. 1984 Dec;46(3):809-13.

Weiler JM, Daha MR, Austen KF, Fearon DT. Control of the amplification convertase of complement by the plasma protein beta1H. Proc Natl Acad Sci U S A. 1976 Sep;73(9):3268 72 .

Werts C, Tapping RI, Mathison JC, Chuang TH, Kravchenko V, Saint Girons I, Haake DA, Godowski PJ, Hayashi F, Ozinsky A, Underhill DM, Kirschning CJ, Wagner H, Aderem A, Tobias PS, Ulevitch RJ. Leptospiral lipopolysaccharide activates cells through a TLR2 dependent mechanism. Nat Immunol. 2001 Apr;2(4):346-52.

Wolff DG, Castiblanco-Valencia MM, Abe CM, Monaris D, Morais ZM, Souza GO, Vasconcellos SA, Isaac L, Abreu PA, Barbosa AS. Interaction of leptospira elongation factor tu with plasminogen and complement factor h: a metabolic leptospiral protein with moonlighting activities. PLoS One. 2013 Nov 27;8(11):e81818.

Woo TH, Smythe LD, Symonds ML, Norris MA, Dohnt MF, Patel BK. Rapid distinction between Leptospira interrogans and Leptospira biflexa by PCR amplification of $23 \mathrm{~S}$ ribosomal DNA. FEMS Microbiol Lett. 1997 May 1;150(1):9-18.

Würzner R. Evasion of pathogens by avoiding recognition or eradication by complement, in part via molecular mimicry. Mol Immunol. 1999 Mar-Apr;36(4-5):249-60.

Yan W, Faisal SM, McDonough SP, Divers TJ, Barr SC, Chang CF, Pan MJ, Chang YF. Immunogenicity and protective efficacy of recombinant Leptospira immunoglobulin-like protein B (rLigB) in a hamster challenge model. Microbes Infect. 2009 Feb;11(2):230-7.

Yan Y, Chen Y, Liou W, Ding J, Chen J, Zhang J, Zhang A, Zhou W, Gao Z, Ye X, Xiao Y. An evaluation of the serological and epidemiological effects of the outer envelope vaccine to leptospira. J Chin Med Assoc. 2003 Apr;66(4):224-30.

Zipfel PF, Jokiranta TS, Hellwage J, Koistinen V, Meri S. The factor H protein family. Immunopharmacology. 1999 May;42(1-3):53-60. 
Zipfel PF, Skerka C, Hellwage J, Jokiranta ST, Meri S, Brade V, Kraiczy P, Noris M, Remuzzi G. Factor $\mathrm{H}$ family proteins: on complement, microbes and human diseases. Biochem Soc Trans. 2002 Nov;30(Pt 6):971-8.

Zipfel PF, Würzner R, Skerka C. Complement evasion of pathogens: common strategies are shared by diverse organisms. Mol Immunol. 2007 Sep;44(16):3850-7.

Zipfel PF. Complement factor H: physiology and pathophysiology. Semin Thromb Hemost. 2001 Jun;27(3):191-9.

Zorio E, Gilabert-Estellés J, España F, Ramón LA, Cosín R, Estellés A. Fibrinolysis: the key to new pathogenetic mechanisms. Curr Med Chem. 2008;15(9):923-9. 
APÊNDICE - Artigos Publicados

1. Castiblanco-Valencia MM, Fraga TR, Silva LB, Monaris D, Abreu PA, Strobel S, Józsi M, Isaac L, Barbosa AS. Leptospiral immunoglobulin-like proteins interact with human complement regulators factor H, FHL-1, FHR-1, and C4BP. The Journal of Infectious Diseases. 2012 Mar 15;205(6):995-1004. (Disponível em versão on-line; doi: 10.1093/infdis/jir875).

2. Wolff DG, Castiblanco-Valencia MM, Abe CM, Monaris D, Morais ZM, Souza GO, Vasconcellos SA, Isaac L, Abreu PA, Barbosa AS. Interaction of leptospira elongation factor tu with plasminogen and complement factor h: a metabolic leptospiral protein with moonlighting activities. PLoS One. 2013 Nov 27;8(11):e81818. (Disponível em versão online; doi: 10.1371/journal.pone.0081818).

3. Fraga TR, Courrol Ddos S, Castiblanco-Valencia MM, Hirata IY, Vasconcellos SA, Juliano L, Barbosa AS, Isaac L. Immune evasion by pathogenic Leptospira strains: the secretion of proteases that directly cleave complement proteins. The Journal of Infectious Diseases. 2014 Mar; 209(6):876-86. (Disponível em versão on-line; doi: 10.1093/infdis/jit569).

4. Albuquerque JA, Lamers ML, Castiblanco-Valencia MM, Dos Santos M, Isaac L. Chemical chaperones curcumin and 4-phenylbutyric acid improve secretion of mutant factor H R127H by fibroblasts from a factor H-deficient patient. Journal of Immunology. 2012 Sep 15;189(6):3242-8. (Disponivél em versão on-line; doi: 10.4049/jimmunol.1201418).

5. Silva AS, Valencia MM, Cianciarullo AM, Vasconcellos SA, Barbosa AS, Isaac L. Interaction of human complement factor $\mathrm{H}$ variants $\mathrm{Tyr}^{40_{2}}$ and $\mathrm{His}^{40_{2}}$ with Leptospira spp. Frontiers Immunology. 2011 Oct 5;2:44. (Disponível em versão on-line; doi: 10.3389/fimmu.2011.00044). 


\title{
Leptospiral Immunoglobulin-like Proteins Interact With Human Complement Regulators Factor H, FHL-1, FHR-1, and C4BP
}

\author{
Mónica Marcela Castiblanco-Valencia, ${ }^{1}$ Tatiana Rodrigues Fraga, ${ }^{1}$ Ludmila Bezerra da Silva, ${ }^{2}$ Denize Monaris, ${ }^{2}$ \\ Patrícia Antônia Estima Abreu, ${ }^{2}$ Stefanie Strobel, ${ }^{3}$ Mihály Józsi, ${ }^{3}$ Lourdes Isaac, ${ }^{1}$ and Angela Silva Barbosa ${ }^{2}$ \\ 'Department of Immunology, Institute of Biomedical Sciences, University of São Paulo, 2Laboratory of Bacteriology, Butantan Institute, São Paulo, Brazil; \\ and ${ }^{3}$ Junior Research Group Cellular Immunobiology, Leibniz Institute for Natural Product Research and Infection Biology-Hans Knöll Institute, \\ Jena, Germany
}

Leptospira, the causative agent of leptospirosis, interacts with several host molecules, including extracellular matrix components, coagulation cascade proteins, and human complement regulators. Here we demonstrate that acquisition of factor $\mathrm{H}$ (FH) on the Leptospira surface is crucial for bacterial survival in the serum and that these spirochetes, besides interacting with $\mathrm{FH}$, FH related-1, and $\mathrm{C} 4 \mathrm{~b}$ binding protein (C4BP), also acquire $\mathrm{FH}$ like-1 from human serum. We also demonstrate that binding to these complement regulators is mediated by leptospiral immunoglobulin-like (Lig) proteins, previously shown to interact with fibronectin, laminin, collagen, elastin, tropoelastin, and fibrinogen. Factor $\mathrm{H}$ binds to Lig proteins via short consensus repeat domains 5 and 20. Competition assays suggest that FH and C4BP have distinct binding sites on Lig proteins. Moreover, FH and C4BP bound to immobilized Ligs display cofactor activity, mediating C3b and C4b degradation by factor I. In conclusion, Lig proteins are multifunctional molecules, contributing to leptospiral adhesion and immune evasion.

Leptospirosis is a worldwide zoonosis and represents a serious health problem in urban areas of tropical developing countries that lack proper sanitation facilities. This neglected infectious disease is caused by spirochetes from the genus Leptospira, which includes pathogenic and saprophytic species [1]. After penetrating the host, successful colonization of target organs by pathogenic Leptospira species is dependent on the bacteria's ability to escape from the host's innate defense mechanisms. The complement system seems to be the major actor in

Received 3 August 2011; accepted 25 October 2011; electronically published 30 January 2012

Presented in part: XXIII International Complement Workshop, New York, New York, 1-5 August 2010. Abstract 230; and the Current Opinion ConferencesCellular Host-Pathogen Interactions, Amsterdam, the Netherlands, 5-7 September 2010. Abstract PS1.32.

Correspondence: Lourdes Isaac, PhD, Departamento de Imunologia, Instituto de Ciências Biomédicas da Universidade de São Paulo. Av Prof Lineu Prestes 1730, 05508-900, São Paulo, SP, Brazil (louisaac@icb.usp.br).

The Journal of Infectious Diseases 2012;205:995-1004

(C) The Author 2012. Published by Oxford University Press on behalf of the Infectious Diseases Society of America. All rights reserved. For Permissions, please e-mail: journals.permissions@oup.com

DOl: 10.1093/infdis/jir875 the nonspecific immune response to Leptospira. This is supported by in vitro results demonstrating that saprophytic leptospiral strains are killed within a few minutes in the presence of normal human serum whereas pathogenic strains are able to survive for longer periods of time $[2,3]$. Therefore, it is clear that pathogenic leptospires have evolved strategies to evade complement attack

In order to avoid tissue destruction in the host, the complement system is kept under strict control. Inappropriate activation of complement in the fluid phase is prevented by the regulatory proteins factor $\mathrm{H}(\mathrm{FH})$ and $\mathrm{C} 4 \mathrm{~b}$ binding protein $(\mathrm{C} 4 \mathrm{BP})$, the major negative regulators of the alternative pathway and the classical and lectin pathways, respectively. Factor $\mathrm{H}$, a $150-\mathrm{kDa}$ plasma protein composed of 20 globular domains termed short consensus repeats (SCRs), inhibits the alternative pathway of complement by preventing binding of factor B to C3b, accelerating decay of the $\mathrm{C} 3$ convertase $\mathrm{C} 3 \mathrm{bBb}$ and acting as a cofactor for the cleavage of C3b by factor I (FI) [4-6]. C4b binding protein is a $570-\mathrm{kDa}$ plasma glycoprotein composed of 
7 identical $\alpha$-chains and a unique $\beta$-chain linked together by a central core [7-9]. C4b binding protein inhibits the classical and lectin pathways of complement by interfering with the assembly and facilitating the decay of the C3 convertase C4bC2a and acts as a cofactor for FI in the proteolytic inactivation of $\mathrm{C} 4 \mathrm{~b}[9,10]$. One strategy adopted by pathogens to avoid destruction by complement relies on their ability to acquire host fluid-phase regulators, and it has been demonstrated that pathogenic strains of Leptospira bind $\mathrm{FH}$ and C4BP for complement evasion [2, 3]. To date, only 2 leptospiral proteins (LenA and LenB) have been shown to interact with $\mathrm{FH}[11,12]$, and a single leptospiral protein named LcpA has been shown to bind C4BP [13]. Considering that leptospires are highly invasive microorganisms, there may be several other bacterial ligands for these host molecules.

The family of leptospiral immunoglobulin-like (Lig) proteins comprises LigA, LigB, and LigC. These proteins belong to the superfamily of bacterial immunoglobulin-like repeat domain proteins, which includes virulence determinants, such as intimin from enteropathogenic Escherichia coli [14] and invasin from Yersinia pseudotuberculosis [15]. The N-terminal 630 amino acid sequences of LigA and LigB are identical, but the C-terminal amino acid sequences are variable with approximately $34 \%$ of identities. LigB also has a C-terminal, nonrepeat domain of 771 amino acid residues; ligC is a pseudogene in Leptospira interrogans serovar Copenhageni and Leptospira kirshneri serovar Grippotyphosa [16-18].

The lig genes are present in pathogenic but not saprophytic Leptospira species. The expression of Lig proteins is closely associated with host infection because they are expressed in virulent strains but not in culture-attenuated leptospires. Furthermore, Lig proteins are able to induce antibody responses in patients and infected animals [16, 17, 19]. Their expression is controlled by osmolarity, a key environmental signal that enhances binding of Leptospira to host cells [20, 21]. They have been identified as extracellular matrix-binding proteins because they are able to interact with fibronectin, laminin, collagen, fibrinogen, elastin, and tropoelastin [22-29]. Because important virulence factors of many pathogens may interact with multiple host proteins, including coagulation cascade molecules, extracellular matrix components, and complement regulators, during infection, we decided to evaluate whether the Lig proteins would contribute to leptospiral immune evasion by interacting with host complement regulators.

\section{MATERIALS AND METHODS}

\section{Bacterial Strains and Plasmids}

Pathogenic L. interrogans serovar Pomona strain Fromm was cultured at $29^{\circ} \mathrm{C}$ under aerobic conditions as previously described [30]. Escherichia coli DH5 $\alpha$ was used as the cloning host strain and E. coli BL21 (DE3) was used as the host strain for the expression of the recombinant proteins, using the T7 promoter-based expression plasmid pAE [31].

\section{Sera, Purified Proteins, and Antibodies}

Normal human sera (NHS) were obtained from healthy donors. The sera were pooled and stored at $-80^{\circ} \mathrm{C}$. Human $\mathrm{FH}, \mathrm{FH}-$ depleted human serum (FH-depl), C4BP, C3b, C4b, and FI were purchased from Complement Technology. Rabbit antihuman FH was a gift from Dr Sánchez-Corral (University Hospital La Paz, Madrid, Spain), goat antihuman FH was purchased from Quidel, and rabbit antihuman C4BP was purchased from Calbiochem. Goat antihuman C3 polyclonal antibody was purchased from Complement Technology, mouse anti-human C4d monoclonal antibody was purchased from Quidel, and secondary peroxidase-conjugated antibodies were purchased from Sigma-Aldrich. The antihuman FH monoclonal antibodies 131X [32] and A229 were obtained from Quidel, C18 [33] was obtained from Enzo Life Sciences, and OX24 [32] was obtained from Santa Cruz Biotechnology. Codon-optimized FH deletion mutants comprising SCRs 1-4, SCRs 8-14, and SCRs 15-20, as well as FH like-1 (FHL-1) and FH related-1 (FHR-1) proteins, were synthetized (GenScript), cloned into the pBSV-8His vector, expressed in insect cells, and purified as described [34].

\section{Cloning, Expression, and Purification of Lig Fragments in E. coli} The coding sequences of LigAC (nucleotides 1891-3675), LigBN (nucleotides 76-1890), and LigBC (nucleotides 1891-3468) were amplified by polymerase chain reaction from genomic DNA of L. interrogans strain 10A using the following primers: LigAC, F: CTCGAGCTTACCGTTTCCAACACAAAC/ R:CCATGGTTATGGCTCCGTTTTAATAGAG; LigBN， F: CCTCGAGGGTCTGGTAGGATTAAC/R:CCATGGCTAAATAT CCGTATTAGAGG; LigBC, F: CTCGAGGCTGAAATTAAAAA TACC/R:GAAGCTTTTAGGATAAATCAAGGG. Cloning, expression, and purification of recombinant proteins with an amino-terminal $6 \mathrm{xHis}$ tag were performed as previously described [13].

\section{Serum Susceptibility Assay}

Leptospires were grown to late log phase and washed twice with phosphate-buffered saline (PBS). Bacteria $\left(1.0 \times 10^{8}\right)$ were incubated at $37^{\circ} \mathrm{C}$ for 120 minutes with $40 \%$ of FH-depl or with $40 \%$ of $\mathrm{FH}$-depl reconstituted with purified $\mathrm{FH}$ (50-500 $\mu \mathrm{g} / \mathrm{mL})$. Bacterial survival was assessed by counting viable organisms using dark field microscopy and a PetroffHausser chamber. Three independent experiments were performed. For statistical analyses, survival in each condition was compared with survival in FH-depl by using the Student 2-tailed $t$ test.

\section{Interaction of $\boldsymbol{L}$. interrogans with FH, FHL-1, and FHR-1}

Freshly harvested leptospires $\left(1.0 \times 10^{9}\right)$ were washed with PBS and then incubated with $2 \mu \mathrm{g}$ of purified FH, recombinant FHL-1 
(rFHL-1), or recombinant FHR-1 (rFHR-1) for 60 minutes at $37^{\circ} \mathrm{C}$ with agitation. After washing, whole cell lysates were subjected to $10 \%$ sodium dodecyl sulfate polyacrylamide gel electrophoresis (SDS-PAGE) under nonreducing conditions and transferred to a nitrocellulose membrane [13], which was incubated with a polyclonal antihuman FH (1:10 000), followed by a peroxidase-conjugated antigoat immunoglobulin $\mathrm{G}$ (IgG) (1:10000). Positive signals were detected by enhanced chemiluminescence (West Pico, Pierce).

\section{Protein Interaction Assays}

For ligand affinity blotting, recombinant proteins were subjected to $10 \%$ SDS-PAGE under nonreducing conditions and transferred to nitrocellulose membranes [13]. The membranes were incubated for 90 minutes with 10\% NHS as a source of $\mathrm{FH}$ or with purified C4BP $(100 \mu \mathrm{g})$ diluted in PBS-Tween $(0.05 \%)$. After washing, the membranes were incubated with polyclonal rabbit antibodies recognizing either human $\mathrm{FH}$ or C4BP (1:5000), followed by peroxidase-conjugated secondary antibodies (1:5000). Positive signals were detected by enhanced chemiluminescence (West Pico, Pierce).

For enzyme-linked immunosorbent assay (ELISA), microtiter plates were coated with $\operatorname{LigAC}, \operatorname{LigBC}, \operatorname{LigBN}$, or the negative control protein encoded by LIC10301 or bovine serum albumin (BSA) $(100 \mu \mathrm{L}$ or $10 \mu \mathrm{g} / \mathrm{mL}$, respectively) overnight at $4^{\circ} \mathrm{C}$. The wells were washed with PBS, blocked with PBS- $1 \%$ BSA for 2 hours at $37^{\circ} \mathrm{C}$, and incubated with purified $\mathrm{FH}$ or C4BP (100 $\mu \mathrm{L}$ or $0-50 \mu \mathrm{g} / \mathrm{mL}$, respectively) for 60 minutes at room temperature (RT). After washing with PBS, bound proteins were detected with rabbit antihuman $\mathrm{FH}$ or rabbit antihuman C4BP (1:5000), followed by peroxidase-conjugated antirabbit IgG (1:5000). Substrate reaction was performed with o-phenylenediamine dihydrochloride (Pierce), and absorbance was measured at $492 \mathrm{~nm}$.

Competition of FH and C4BP binding to immobilized Lig proteins was assessed by ELISA. Wells were coated with the recombinant proteins and blocked as described above. One microgram of $\mathrm{FH}$ mixed with different amounts of C4BP (different molar ratios) was added to each well, and the bound proteins were detected with either rabbit antihuman $\mathrm{FH}$ or rabbit antihuman C4BP.

Localization of binding regions within $\mathrm{FH}$ was also achieved using an ELISA-based assay. Lig proteins were immobilized as described above and, after blocking, incubated with $2 \mu \mathrm{g}$ of rFHL-1, rFHR-1, SCRs 1-4 (N-terminal region of FH), SCRs 8-14 (central region of FH), and SCRs 15-20 construct (C-terminal region of $\mathrm{FH}$ ). Intact purified $\mathrm{FH}$ was included as a control. Bound proteins were detected with goat antihuman $\mathrm{FH}$, which reacted similarly with all constructs.

Inhibition assays were performed by preincubating purified $\mathrm{FH}(1 \mu \mathrm{g})$ for 30 minutes at RT with monoclonal antibodies directed against different regions of $\mathrm{FH}$ ( $1 \mu \mathrm{g}$ each). Factor $\mathrm{H}$ was then allowed to interact with immobilized LigBC and was detected with goat antihuman FH (1:10 000).

\section{Cofactor Activity Assay}

Cofactor activity of $\mathrm{FH}$ or C4BP bound to LigAC, LigBC, LigBN, and rLIC10301 (negative control) was analyzed by measuring FI-mediated cleavage of $\mathrm{C} 3 \mathrm{~b}$ ( $\mathrm{FH}$ as a cofactor) or C4b (C4BP as a cofactor). Microtiter plate wells were coated with $1 \mu \mathrm{g}$ of each recombinant protein diluted in PBS for 16 hours at $4^{\circ} \mathrm{C}$. After blocking with $3 \%$ BSA, $2 \mu \mathrm{g}$ of $\mathrm{FH}$ or C4BP or 5\% NHS was added to each well for 60 minutes at $37^{\circ} \mathrm{C}$. After washing with $\mathrm{PBS}, \mathrm{C} 3 \mathrm{~b}$ or $\mathrm{C} 4 \mathrm{~b}$, both $500 \mathrm{ng}$ per assay, and FI at $250 \mathrm{ng}$ per reaction were added to the wells and incubated for up to 240 minutes at $37^{\circ} \mathrm{C}$. Reaction mixtures were subjected to Western blotting, and cleavage fragments of $\mathrm{C} 3 \mathrm{~b}$ and $\mathrm{C} 4 \mathrm{~b}$ were detected with goat antihuman $\mathrm{C} 3$ polyclonal antibodies (1:10 000) or with a mouse antihuman C4d monoclonal antibody (1:1000), followed by incubation with secondary peroxidase-conjugated antibodies. Cofactor activity of FH or FHL-1 bound to intact L. interrogans strain Fromm was assessed as previously described [13].

\section{RESULTS}

\section{Acquisition of FH contributes to Leptospira Survival}

Acquisition of host $\mathrm{FH}$ as a strategy for leptospiral complement evasion has been previously described [2]. Surface-bound FH retains cofactor activity in the cleavage of $\mathrm{C} 3 \mathrm{~b}$ by FI, indicating that acquisition of this complement regulator may contribute to leptospiral serum resistance [2]. To further assess the protective role of acquired $\mathrm{FH}, L$. interrogans serovar Pomona strain Fromm, previously shown to resist human complement [3], was incubated in FH-depl and in the same serum reconstituted with purified $\mathrm{FH}$ up to $500 \mu \mathrm{g} / \mathrm{mL}$ (FH physiological concentration: $443 \pm 106$ [35]). Addition of FH to the depleted serum significantly increased bacterial survival in a dose-dependent manner (Figure 1).

\section{Pathogenic Leptospira Bind FH, FHL-1, and FHR-1}

Previous data demonstrated that pathogenic Leptospira bind $\mathrm{FH}$ and, most probably, FHR-1 $\alpha / \beta$ from human serum [2]. In this study, we used rFHL-1 and rFHR-1 to more precisely ascertain which $\mathrm{FH}$ family proteins interact with Leptospira. Bacteria were incubated with purified $\mathrm{FH}$ or with the recombinant proteins mentioned above, and whole cell lysates were subjected to Western blotting with anti-FH. Bands corresponding to $\mathrm{FH}$ (155 kDa), rFHL-1 (43 kDa), and rFHR-1 (42 kDa) were detected, thus showing that pathogenic Leptospira bind at least these 3 members of the $\mathrm{FH}$ protein family (Figure 2A). Cofactor activity of bacterial surface-attached $\mathrm{FH}$ and rFHL-1 was assayed by measuring FI-mediated cleavage of C3b. As expected, FI cleaved C3b $\alpha$ ' chain $(110 \mathrm{kDa})$ in the presence of $\mathrm{FH}$ and rFHL-1, generating cleavage products 


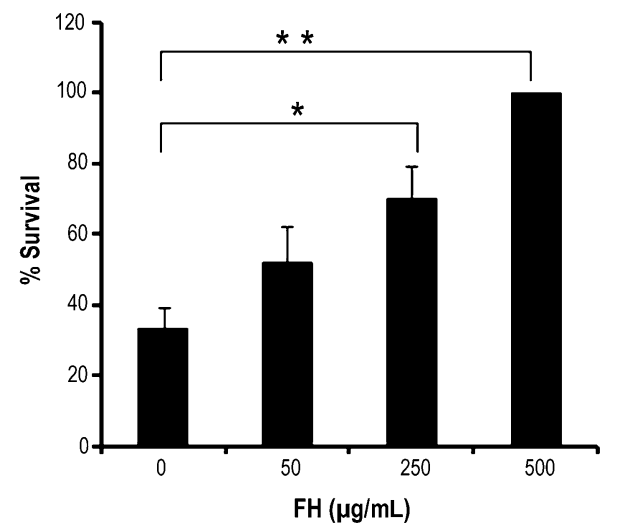

Figure 1. Survival of Leptospira interrogans serovar Pomona as a function of increasing concentrations of factor $\mathrm{H}(\mathrm{FH})$. The pathogenic $L$. interrogans strain Fromm was incubated in FH-depleted serum reconstituted with different amounts of purified $\mathrm{FH}$ up to physiological concentrations $(500 \mu \mathrm{g} / \mathrm{mL})$. Survival at this concentration was set as $100 \%$. Means \pm SD for 3 independent experiments are shown. ${ }^{*} P<.05$; ${ }^{*} P<.01$.

ranging from 28 to $43 \mathrm{kDa}$ (Figure $2 B$ ). Cleavage was much more efficient in the presence of $\mathrm{FH}$, as indicated by the complete disappearance of the $110 \mathrm{kDa} \mathrm{C} 3 \mathrm{~b} \alpha$ chain. Interestingly, 1 or more bacterial compounds may act as FI cofactor(s) because similar C3b cleavage profiles were observed in the presence of FHL-1 or in the absence of any cofactor added (Figure $2 B$ ). Another possibility is that protease(s) on the surface of, or secreted by, pathogenic Leptospira may also contribute to C3b cleavage (Fraga TR, Vasconcellos SA, Barbosa AS, Isaac L, unpublished data).

\section{Lig Proteins Interact With the Complement Regulators FH and C4BP}

Considering that Lig proteins are multifunctional molecules capable of interacting with various host proteins, we decided to evaluate whether they would contribute to leptospiral immune evasion by binding human complement regulators. Because LigA and LigB share 100\% sequence identity at their $\mathrm{N}$-terminus but vary at their C-terminus, 3 fragments were produced and purified: LigAC, LigBC, and LigBN (corresponding to the shared $\mathrm{N}$-terminal region of both proteins) (Figure $3 A$ ). SDS-PAGE gels of the purified recombinant proteins are shown in Figure $3 B$. Ligand affinity blotting and ELISA were used to assess binding of Lig proteins to $\mathrm{FH}$ and C4BP. Both complement regulators bound to the $\mathrm{N}$-terminus and the C-terminus of the Lig proteins (Figure $4 A$ ). LcpA, a leptospiral protein previously shown to interact with C4BP [13], was included as a positive control (Figure $4 A$ ). In ELISA assays, a dose-dependent binding of $\operatorname{Lig} A C$, LigBC, and $\operatorname{LigBN}$ to purified $\mathrm{FH}$ and $\mathrm{C} 4 \mathrm{BP}$ was observed (Figure $4 B$ ). No binding to $\mathrm{FH}$ or $\mathrm{C} 4 \mathrm{BP}$ was detected with BSA or with rLIC10301 (negative controls) (Figure $4 A$ and $4 B$ ). From these results, we
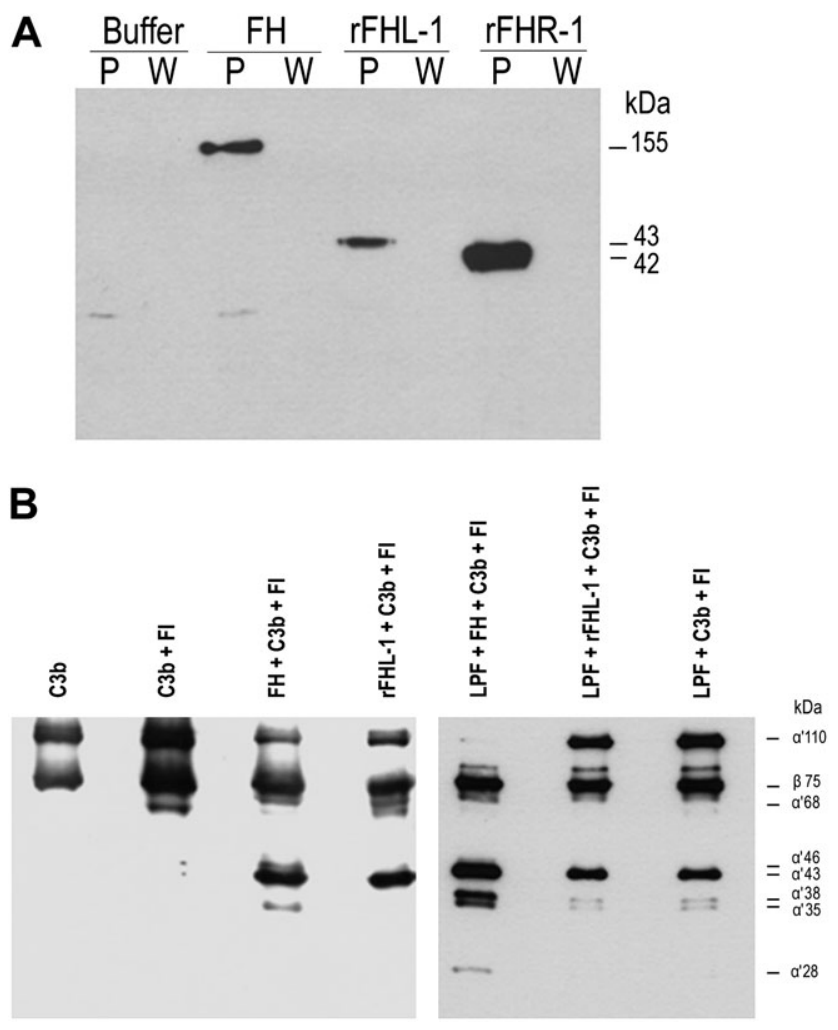

Figure 2. Interaction of Leptospira interrogans with factor $\mathrm{H}(\mathrm{FH})$, FH like-1 (FHL-1), and FH related-1 (FHR-1). A, The serum-resistant L. interrogans serovar Pomona strain Fromm was incubated with purified FH, recombinant FHL-1 (rFHL-1), recombinant FHR-1 (rFHR-1), or buffer. Whole cell lysates were subjected to Western blotting with anti-FH. Bands corresponding to FH (155 kDa), rFHL-1 (43 kDa), and rFHR-1 (42 kDa) were detected. P, bacterial pellets; $W$, aliquots of the last wash. $B$, L. interrogans serovar Pomona strain Fromm (LPF) was incubated with $2 \mu \mathrm{g}$ of purified $\mathrm{FH}$ or $\mathrm{rHH}-1$ as well as in the absence of any cofactor. After extensive washing, C3b and factor I (FI) were added. Incubation proceeded for $2 \mathrm{~h}$ and the bacteria were pelleted by centrifugation. Samples from supernatants were subjected to reducing sodium dodecyl sulfate polyacrylamide gel electrophoresis and analyzed with polyclonal anti-C3 antibodies. C3b cleavage fragments ranging from 28 to $68 \mathrm{kDa}$ are apparent. Control reactions without bacteria are shown to the left.

conclude that Lig proteins interact with $\mathrm{FH}$ and $\mathrm{C} 4 \mathrm{BP}$ through at least 2 different binding sites, 1 located within the $\mathrm{N}$-terminal domain and the other within the C-terminal domain.

\section{FH and C4BP Retain Cofactor Activity When Bound to LigA and LigB}

To assess the functional activity of $\mathrm{FH}$ and $\mathrm{C} 4 \mathrm{BP}$ upon binding to Lig proteins, LigAC, LigBC, LigBN, and rLIC10301 (negative control) were immobilized and incubated with NHS, purified $\mathrm{FH}$ or purified C4BP. After washing, $\mathrm{C} 3 \mathrm{~b}$ or $\mathrm{C} 4 \mathrm{~b}$ and FI were added. The cleavage of $\mathrm{C} 3 \mathrm{~b}$ or $\mathrm{C} 4 \mathrm{~b}$ was analyzed by Western blotting using antihuman $\mathrm{C} 3$ polyclonal or $\mathrm{C} 4 \mathrm{~d}$ monoclonal antibodies. As depicted in Figure 5, LigAC, LigBC, and LigBN were able to bind $\mathrm{FH}$ and $\mathrm{C} 4 \mathrm{BP}$, which retained their cofactor 
A LigA $\mathrm{N}-(1)(2)(3)(4)(5)(7)(3)(9)(10)(11)(12)(13-C$

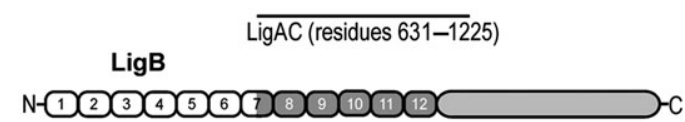

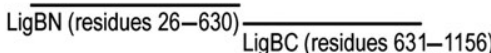

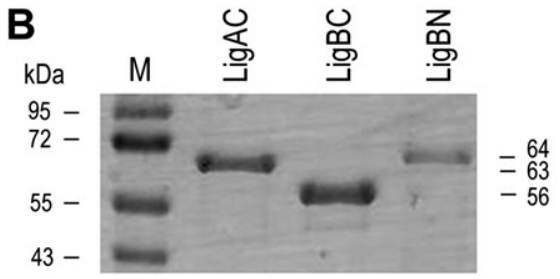

Figure 3. Leptospiral immunoglobulin-like proteins $\mathrm{A}$ (LigA) and B (LigB). $A$, Schematic diagram of LigA and LigB proteins with 13 and 12 bacterial immunoglobulin-like (Big) domain repeats, respectively. LigAC comprises half of Big domain 7 and Big domains 8 to 13 of LigA (residues 631-1225); LigBN comprises Big domains 1 to 6 and half of Big domain 7 of LigB (residues 26-630); LigBC comprises half of Big domain 7 and Big domains 8 to 12 (residues 631-1156). B, Sodium dodecyl sulfate polyacrylamide gel electrophoresis of purified recombinant proteins obtained by metal affinity chromatography. M: molecular mass standard (PageRuler, Fermentas); LigAC: 63 kDa; LigBC: 56 kDa; LigBN: 64 kDa.

activities. When the proteins were incubated with serum or $\mathrm{FH}$, the C3b cleavage products $\alpha^{\prime} 68, \alpha^{\prime} 46$, and $\alpha^{\prime} 43$ were produced. Furthermore, when the Lig protein fragments were incubated with serum or C4BP, a $45-\mathrm{kDa}$ band corresponding to C4d could be detected. Cleavage of $\mathrm{C} 4 \mathrm{~b}$ was much more efficient when Lig proteins were incubated with purified C4BP than when incubated with serum. It is possible that $\mathrm{C} 4 \mathrm{BP}$ binding to Ligs may be hampered in the presence of other serum proteins. No C3b or C4b cleavage was observed when rLIC10301was incubated with FH or C4BP (Figure 5).

\section{FH and C4BP Do Not Share Binding Sites for the Lig Proteins}

We next analyzed whether FH and C4BP compete for the same binding sites on Lig proteins. LigAC, LigBC, and LigBN were immobilized in microtiter wells, and competitive binding assays were performed with increasing amounts of C4BP in the presence of a constant amount $(1 \mu \mathrm{g})$ of $\mathrm{FH}$, resulting in different FH:C4BP molar ratios. The wells were probed with either anti-FH or anti-C4BP. As shown in Figure 6, C4BP did not compete with $\mathrm{FH}$ for binding to Lig proteins even at molar ratios beyond that observed in physiological conditions (1 FH: $0.125 \mathrm{C} 4 \mathrm{BP})$. Similar results were observed when $5 \mu \mathrm{g}$ of $\mathrm{FH}$ were used to compete with different concentrations of C4BP. We also obtained equivalent results when $5 \mu \mathrm{g}$ of C4BP were used to compete with different concentrations of $\mathrm{FH}$ (data not shown). We therefore conclude that FH and C4BP do not seem to have overlapping binding sites on Lig proteins.
A

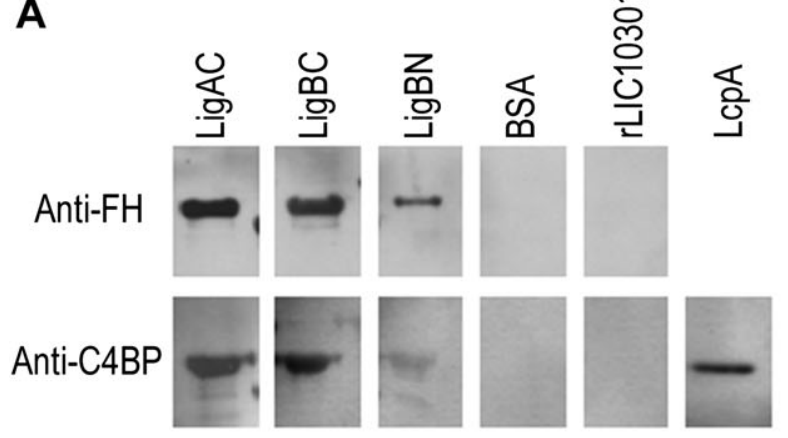

B
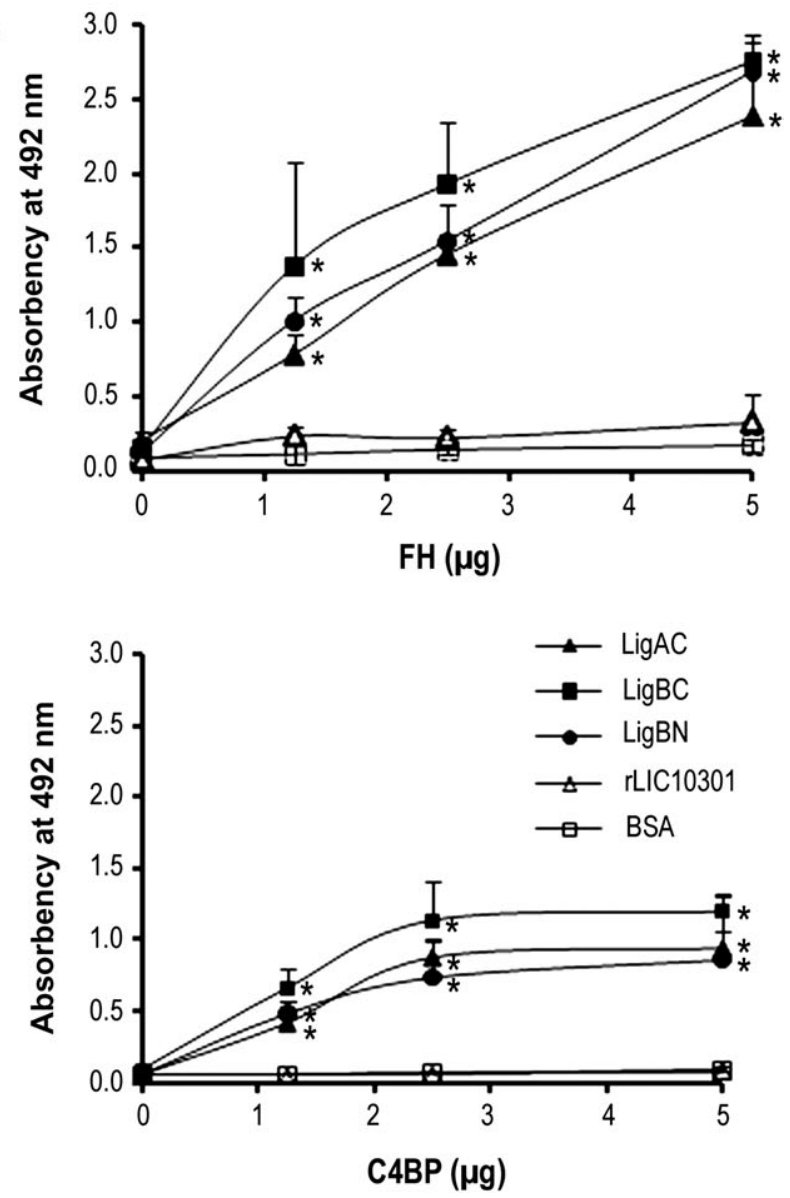

Figure 4. Leptospiral immunoglobulin-like (Lig) proteins interact with the complement regulators factor $\mathrm{H}(\mathrm{FH})$ and $\mathrm{C} 4 \mathrm{~b}$ binding protein (C4BP). $A$, Purified recombinant proteins LigAC, LigBC, and LigBN were subjected to sodium dodecyl sulfate polyacrylamide gel electrophoresis and transferred to nitrocellulose membranes. The membranes were incubated with $10 \%$ normal human sera (as a source of FH) or with purified C4BP. Factor $\mathrm{H}$ and C4BP were detected with specific antibodies by Western blot. Bovine serum albumin and rLIC10301 were included as negative controls, and LcpA was included as a positive control for C4BP binding [13]. $B$, Microtiter plates were coated with $1 \mu \mathrm{g}$ of recombinant proteins, and different amounts of purified FH or C4BP $(0-5 \mu \mathrm{g})$ were added to each well. BSA and rLIC10301 were included as negative controls. Binding was detected with specific antibodies. Each point represents the mean absorbance value at $492 \mathrm{~nm} \pm$ the SD of 3 independent experiments, each performed in duplicate. Binding of $\mathrm{FH}$ or $\mathrm{C} 4 \mathrm{BP}$ to the recombinant proteins was compared with the binding of these molecules to BSA by the 2-tailed $t$ test $\left({ }^{*} P<.05\right)$. 

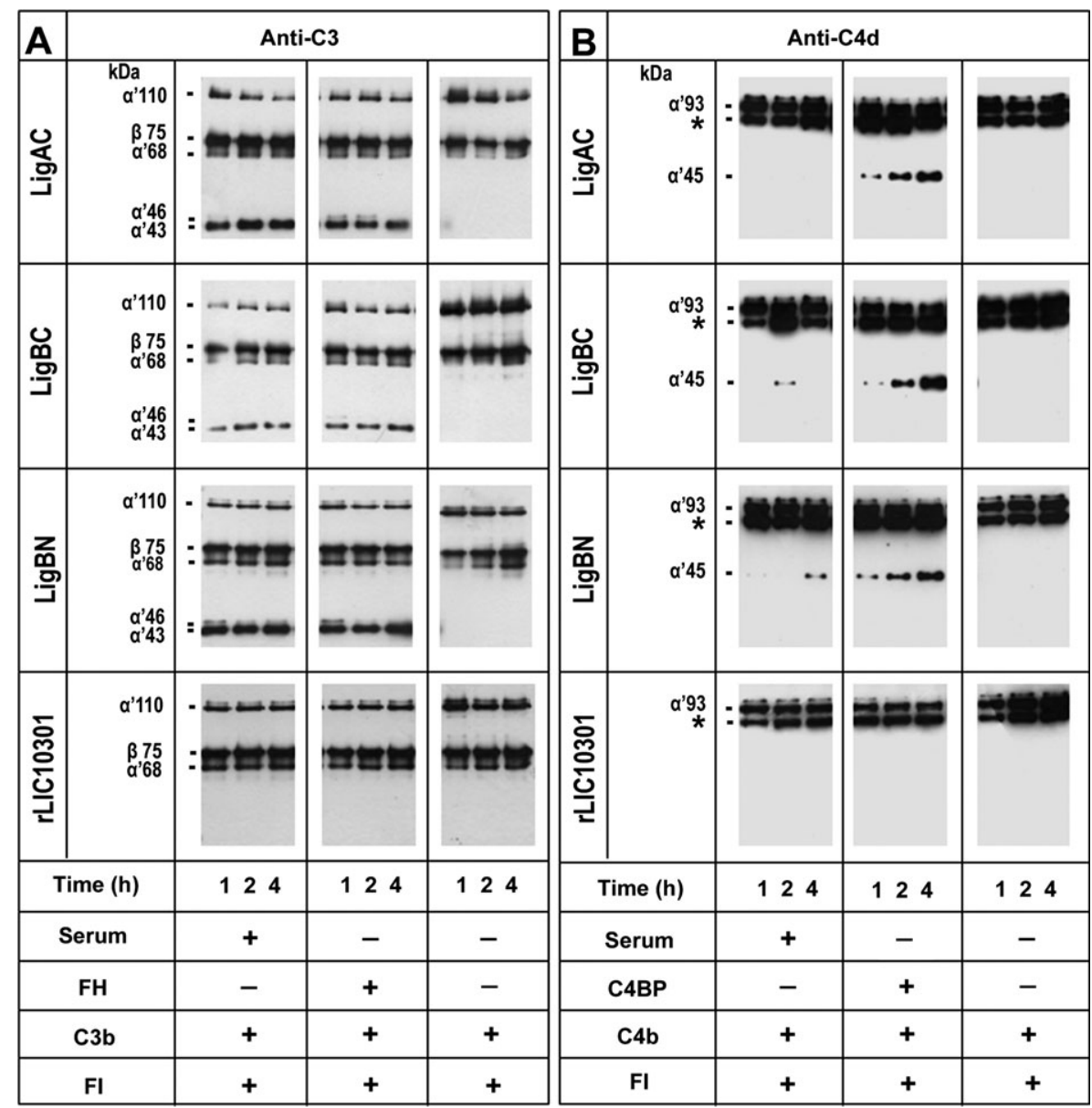

Figure 5. Cofactor activity of factor $\mathrm{H}(\mathrm{FH})$ and $\mathrm{C} 4 \mathrm{~b}$ binding protein (C4BP) bound to leptospiral immunoglobulin-like (Lig) proteins. The recombinant proteins LigAC, LigBC, LigBN, and LIC10301 (1 $\mu \mathrm{g})$ were immobilized on microtiter plates and incubated with $5 \%$ normal human sera or with purified FH or C4BP $(2 \mu \mathrm{g})$. Control reactions in which FH or C4BP were omitted were also performed. After washing, C3b or C4b and factor I (FI) were added. The reactions were incubated for 1,2 , and $4 \mathrm{~h}$ at $37^{\circ} \mathrm{C}$. The products were analyzed by sodium dodecyl sulfate polyacrylamide gel electrophoresis, and the cleavage fragments of C3b or C4b were detected by Western blotting with antihuman C3 polyclonal or C4d monoclonal antibodies. The presence of bands at 43,46 , and $68 \mathrm{kDa}$ indicates that acquired FH was able to promote Fl-mediated cleavage of C3b. The presence of a 45-kDa fragment corresponding to C4d indicates that acquired C4BP was able to promote Fl-mediated cleavage of C4b (anti-C4d monoclonal antibody recognizes both the intact $\alpha^{\prime}$ chain of C4b and its cleaved product C4d). rLIC10301 was used as a negative control because this protein does not bind FH or C4BP. ${ }^{*}$, fragment resulting from partial cleavage of $\mathrm{C} 4 \mathrm{~b}$.

\section{Lig Proteins Interact With FH, FHL-1, and FHR-1}

To map the binding sites within FH that interact with Lig proteins, the latter were immobilized and incubated with fulllength FH, rFHL-1, rFHR-1, or the FH fragments SCRs 1-4, SCRs 8-14, and SCRs 15-20. Factor H, rFHL-1, rFHR-1, and SCRs 15-20 interacted with the N-terminus as well as with the C-terminus of LigA and LigB, whereas SCRs 8-14 did not bind to any of these proteins. These results suggest that the central region of FH is not involved in the binding to Lig proteins. Lig proteins showed a strong binding to the SCRs 15-20 construct, and binding to FHR-1 was even more prominent, suggesting the involvement of both FH SCRs 6-7 and SCRs 18-20 and the corresponding FHR-1 domains in the interaction (Figure $7 A$ ). Contrary to LigAC and LigBN, LigBC seems to harbor an additional binding site within SCR 1-4 (Figure 7A). Monoclonal antibodies directed against SCR 5 and SCR 20 inhibited binding of FH to LigBC by approximately $50 \%$, thus confirming that these particular domains are involved in the interaction of $\mathrm{FH}$ with the $\mathrm{C}$-terminal portion of LigB (Figure $7 B$ ). Similar inhibitory profiles using the same antibodies were observed with LigAC and LigBN (data not shown). A summary of the FH SCR domains that possibly interact with LigA and $\operatorname{LigB}$ is presented in Figure $7 C$.

\section{DISCUSSION}

In this work, we demonstrated that acquisition of $\mathrm{FH}$ by pathogenic Leptospira has a protective role, being crucial for 

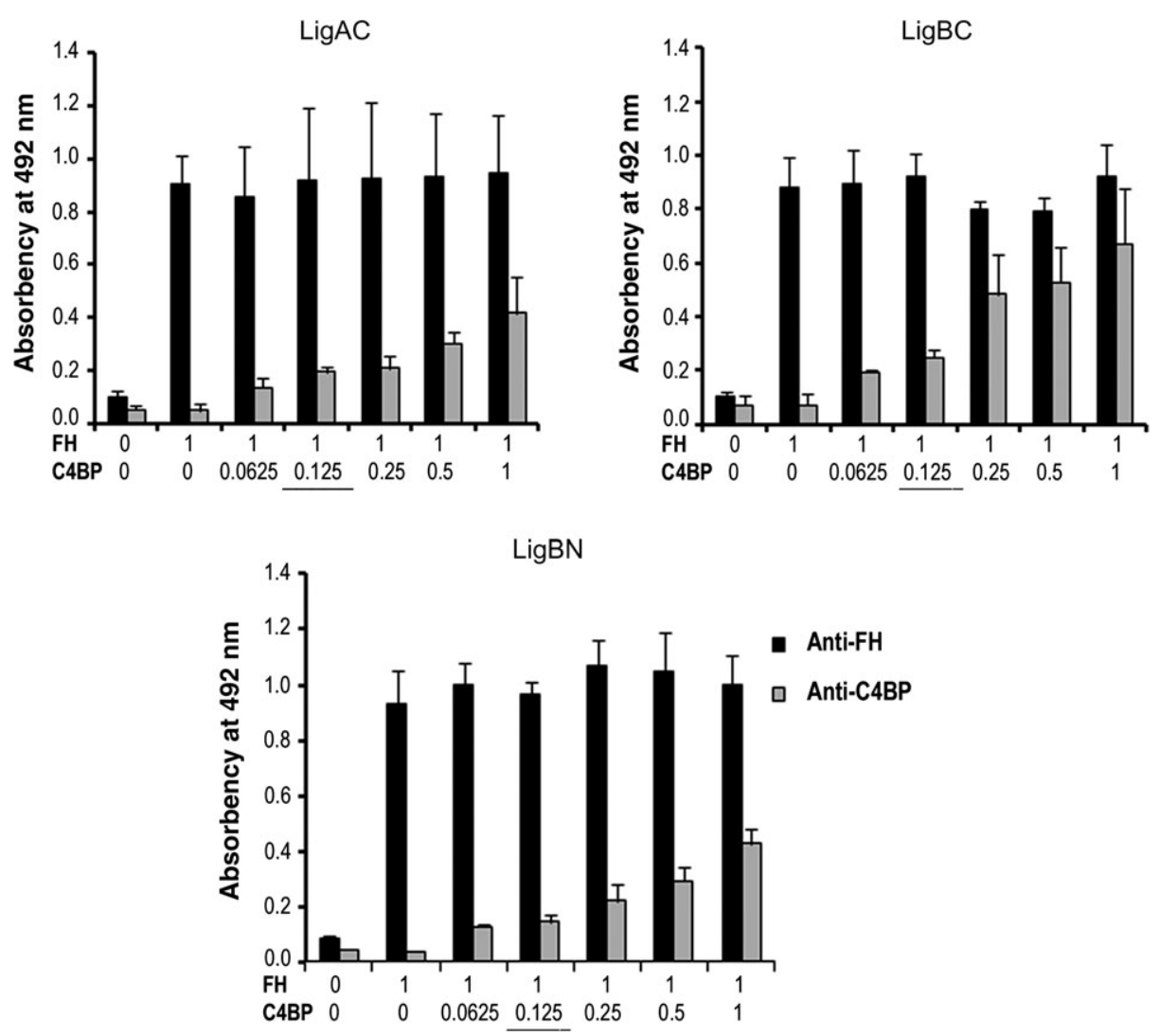

Figure 6. Factor $\mathrm{H}(\mathrm{FH})$ and $\mathrm{C} 4 \mathrm{~b}$ binding protein (C4BP) do not share binding sites for leptospiral immunoglobulin-like (Lig) proteins. Competition inhibition assays were performed in which different amounts of C4BP $(0-40 \mu \mathrm{g} / \mathrm{mL})$ and a constant amount of FH $(10 \mu \mathrm{g} / \mathrm{mL})$ were added to immobilized LigAC, LigBC, and LigBN. Factor H:C4BP molar ratios are indicated below the graphs. Bound FH and C4BP were detected using goat antihuman FH (black boxes) and rabbit antihuman $\mathrm{C4BP}$ antibodies (gray boxes), respectively, followed by peroxidase-conjugated secondary antibodies. Optical densities were determined at $492 \mathrm{~nm}$. Data represent the mean \pm SD of 3 independent experiments, each performed in duplicate.

bacterial survival. We also showed that in addition to interacting with FH, leptospires bind FHL-1 and FHR-1. FHL-1 binding does not seem to be of great relevance for this particular spirochete because similar C3b cleavage profiles were observed in the presence or in the absence of this cofactor (Figure $2 B$ ). However, acquisition of FHR-1 may be advantageous due to its regulatory function at the level of C5 [37]. FHR-1 was shown to inhibit C5 convertase activity and to interfere with C5b surface deposition and terminal complex formation. This activity may be beneficial to a number of bacterial and fungal pathogens ([11,38-42], this study) which, in addition to interacting with $\mathrm{FH}$, also bind FHR-1, allowing control of complement activation at early and late steps of the cascade.

Pathogen-bound FH family proteins can also mediate adhesion and facilitate the invasion of host cells $[43,44]$. On the other hand, the binding of FHR-1 to the pathogen surface may be of advantage to the host for 2 reasons: (1) FHR-1 can compete with $\mathrm{FH}$ due to overlapping binding sites and thus reduce complement control at the surface of the pathogen [39], and (2) both FHR-1 and FH may mediate adhesion and enhance antimicrobial activity of host immune cells, as shown for the interaction of Candida albicans with human neutrophils [45].

Another interesting point that came out of this study was the finding that L. interrogans has both acquired and endogenous complement regulatory activity with regard to $\mathrm{C} 3 \mathrm{~b}$ degradation (Figure $2 B$ ). Studies to identify bacterial surface components with cofactor or protease activity are under way. $\mathrm{C} 3 \mathrm{~b}$ cleavage in the presence of $\mathrm{FH}$ is much more efficient, as illustrated by the complete disappearance of its $110 \mathrm{kDa} \alpha^{\prime}$ chain and the accentuated generation of cleavage products ranging from 28 to $43 \mathrm{kDa}$ (Figure $2 B$ ). Nevertheless, endogenous activity may confer additional survival advantage in the host by contributing to pathogenic Leptospira's ability to control complement activation.

Lig proteins are important virulence factors because loss of their expression correlates with loss of virulence during culture attenuation. Moreover, they are upregulated during host infection $[16,18,20,46]$. These proteins interact with a diverse array of host molecules, including proteins of the extracellular matrix and the coagulation cascade [22-29]. Their functional plurality prompted us to investigate whether they would interact 
A

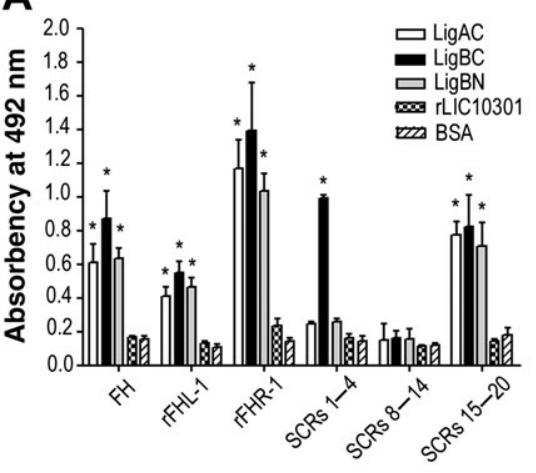

B

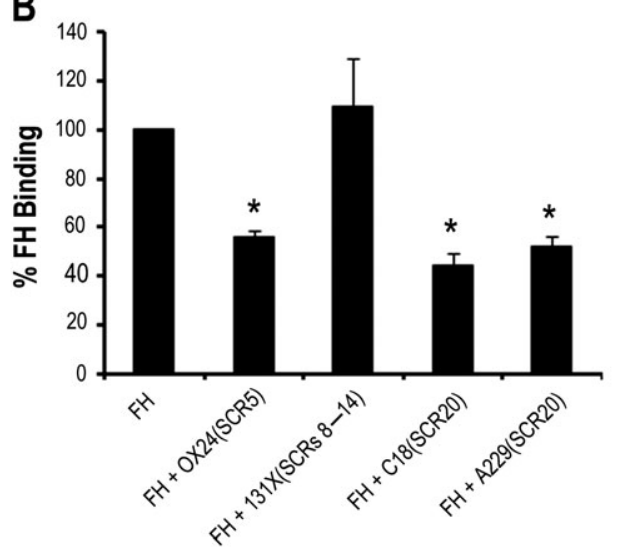

C

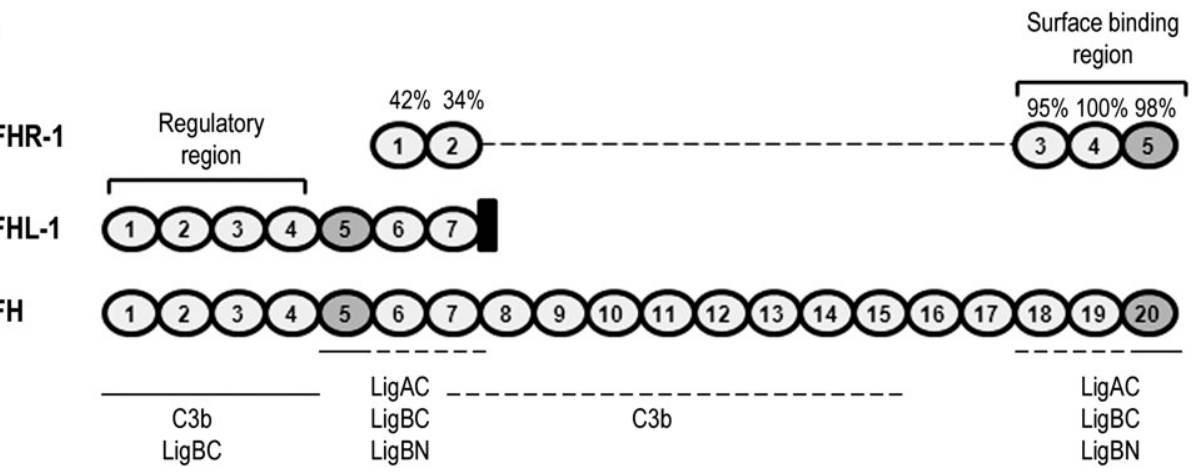

Figure 7. Mapping of factor $\mathrm{H}(\mathrm{FH})$ domains interacting with leptospiral immunoglobulin-like (Lig) proteins. $A$, Recombinant LigAC, LigBC, and LigBN were immobilized and incubated with either full-length FH or recombinant FHL-1 (rFHL-1), recombinant FHR-1 (rFHR-1), or the FH fragments short consensus repeats (SCRs) 1-4, SCRs 8-14, and SCRs 15-20. Bound proteins were detected using goat antihuman FH, followed by a peroxidaseconjugated secondary antibody. Each point represents the mean absorbance value at $492 \mathrm{~nm} \pm$ the SEM of 3 independent experiments, each performed in duplicate. Binding of FH or FH fragments to the recombinant proteins was compared with the binding of these molecules to BSA by the 2-tailed $t$ test ( $\left.{ }^{*} P<.05\right)$. B, One microgram of purified FH was preincubated with $1 \mu \mathrm{g}$ of monoclonal antibodies (OX24 [anti-SCR5], 131X [anti-SCRs 8-14], C18 [antiSCR 20], or A229 [anti-SCR20]) directed against different regions of the molecule. Factor $\mathrm{H}$ was then allowed to interact with immobilized LigBC and was detected as described above. Each point represents the mean absorbance value at $492 \mathrm{~nm} \pm$ the $S D$ of 3 independent experiments, each performed in duplicate. Binding of $\mathrm{FH}$ in the absence of any antibody was set as $100 \%$. ${ }^{*} P<.0001$. C, Schematic representation of FH, FHL-1, and FHR-1 proteins. Short consensus repeat domains are aligned according to their amino acid sequence similarities. LigAC, LigBC, and LigBN binding regions (SCR5-7 and SCR18-20) are highlighted as well as the regulatory domains (SCR1-4) and C3b binding domains (dotted lines: binding sites remain uncertain). This representation is based on [36].

with host complement regulators as well. Our results demonstrate that LigA and LigB bind FH and C4BP from human serum and as purified proteins in a dose-dependent manner. We showed that both the $\mathrm{N}$ - and the C-terminus of these proteins harbor binding sites for $\mathrm{FH}$ and C4BP. Importantly, both complement regulators are capable of acting as cofactors when bound to the Ligs, as indicated by the presence of $\mathrm{C} 3 \mathrm{~b}$ and C4d cleavage fragments after incubation with FI. Our data indicate that C4BP does not inhibit the interaction between $\mathrm{FH}$ and LigAC, LigBC, or LigBN (Figure 6) and vice versa (data not shown), even at FH:C4BP molar ratios beyond those found in the plasma ( $1 \mathrm{FH}: 0.125 \mathrm{C} 4 \mathrm{BP})$. Thus the 2 complement regulators can bind simultaneously. Cleavage of $\mathrm{C} 4 \mathrm{~b}$ was much more efficient in the presence of purified
C4BP compared with the cleavage observed with NHS. This suggests that other serum proteins could compete with C4BP for the same binding sites on the Lig proteins.

In addition to interacting with $\mathrm{FH}$ and $\mathrm{C} 4 \mathrm{BP}$, Lig proteins also bind FHL-1 and FHR-1 (Figure 7A). In an attempt to map the FH domains that interact with the Ligs, recombinant constructs encompassing different FH SCRs and antibodies directed against specific SCRs were used. As for the majority of bacterial proteins described to date (reviewed in [36]), Lig proteins probably interact with FH through SCRs 5-7 and also through carboxy-terminal SCRs 18-20 (Figure 7).

Lig proteins interact with numerous host molecules, notably proteins that mediate attachment to host tissues [22-29]. In this work, we show that these multifunctional leptospiral proteins 
also bind complement regulators. The ability to adhere to host cells and to the extracellular matrix as well as the capacity to escape complement are 2 fundamental activities that greatly contribute to successful colonization of the host. Interestingly, Lig proteins have been shown to be the most promising vaccine candidates against leptospirosis, conferring protective immunity against lethal infection in the hamster model of the disease [47-50]. One possible explanation for the usefulness of Lig proteins as vaccine antigens is that Lig-specific antibodies might be able to block binding of complement regulators and extracellular matrix molecules to the bacterial surface, thereby enhancing leptospiral susceptibility to complement-mediated killing.

\section{Notes}

Acknowledgments. We thank Prof Shaker Chuck Farah (Instituto de Química, Universidade de São Paulo, Brazil) for a critical reading of the manuscript.

Financial support. T his work was supported by Fundação de Amparo à Pesquisa do Estado de São Paulo ( 2010/50043-0).

Potential conflicts of interest. All authors: No reported conflicts.

All authors have submitted the ICMJE Form for Disclosure of Potential Conflicts of Interest. Conflicts that the editors consider relevant to the content of the manuscript have been disclosed.

\section{References}

1. Faine S, Adler B, Bolin C, Perolat P. Leptospira and leptospirosis, 2nd ed. Melbourne: MediScience, 1999.

2. Meri T, Murgia R, Stefanel P, Meri S, Cinco M. Regulation of complement activation at the C3-level by serum resistant leptospires. Microb Pathog 2005; 39:139-47.

3. Barbosa AS, Abreu PA, Vasconcellos SA, et al. Immune evasion of Leptospira species by acquisition of human complement regulator C4BP. Infect Immun 2009; 77:1137-43.

4. Whaley K, Ruddy S. Modulation of the alternative complement pathways by beta $1 \mathrm{H}$ globulin. J Exp Med 1976; 144:1147-63.

5. Weiler JM, Daha MR, Austen KF, Fearon DT. Control of the amplification convertase of complement by the plasma protein beta1H. Proc Natl Acad Sci U S A 1976; 73:3268-72.

6. Pangburn MK, Schreiber RD, Müller-Eberhard HJ. Human complement C3b inactivator: isolation, characterization, and demonstration of an absolute requirement for the serum protein beta1H for cleavage of C3b and C4b in solution. J Exp Med 1977; 146:257-70.

7. Dahlbäck B, Smith CA, Müller-Eberhard HJ. Visualization of human C4b-binding protein and its complexes with vitamin $\mathrm{K}$-dependent protein S and complement protein C4b. Proc Natl Acad Sci U S A 1983; 80:3461-5.

8. Hillarp A, Dahlbäck B. Cloning of cDNA coding for the beta chain of human complement component C4b-binding protein: sequence homology with the alpha chain. Proc Natl Acad Sci U S A 1990; 87 : $1183-7$.

9. Scharfstein J, Ferreira A, Gigli I, Nussenzweig V. Human C4-binding protein. I. Isolation and characterization. J Exp Med 1978; 148:207-22.

10. Gigli I, Fujita T, Nussenzweig V. Modulation of the classical pathway C3 convertase by plasma proteins $\mathrm{C} 4$ binding protein and $\mathrm{C} 3 \mathrm{~b}$ inactivator. Proc Natl Acad Sci U S A 1979; 76:6596-600.

11. Verma A, Hellwage J, Artiushin S, et al. LfhA, a novel factor H-binding protein of Leptospira interrogans. Infect Immun 2006; 74:2659-66.

12. Stevenson B, Choy HA, Pinne M, et al. Leptospira interrogans endostatin-like outer membrane proteins bind host fibronectin, laminin and regulators of complement. PLoS One 2007; 2:e1188.
13. Barbosa AS, Monaris D, Silva LB, et al. Functional characterization of LcpA, a surface-exposed protein of Leptospira spp. that binds the human complement regulator C4BP. Infect Immun 2010; 78:3207-16.

14. Luo Y, Frey EA, Pfuetzner RA, et al. Crystal structure of enteropathogenic Escherichia coli intimin-receptor complex. Nature 2000; 405:1073-7.

15. Hamburger ZA, Brown MS, Isberg RR, Bjorkman PJ. Crystal structure of invasin: a bacterial integrin-binding protein. Science 1999; 286: 291-5.

16. Palaniappan RU, Chang YF, Jusuf SS, et al. Cloning and molecular characterization of an immunogenic LigA protein of Leptospira interrogans. Infect Immun 2002; 70:5924-30.

17. Matsunaga J, Barocchi MA, Croda J, et al. Pathogenic Leptospira species express surface-exposed proteins belonging to the bacterial immunoglobulin superfamily. Mol Microbiol 2003; 49:929-45.

18. Palaniappan RU, Chang YF, Hassan F, et al. Expression of leptospiral immunoglobulin-like protein by Leptospira interrogans and evaluation of its diagnostic potential in a kinetic ELISA. J Med Microbiol 2004; 53:975-84.

19. Koizumi N, Watanabe H. Leptospiral immunoglobulin-like proteins elicit protective immunity. Vaccine 2004; 22:1545-52.

20. Matsunaga J, Sanchez Y, Xu X, Haake DA. Osmolarity, a key environmental signal controlling expression of leptospiral proteins LigA and LigB and the extracellular release of LigA. Infect Immun 2005; 73:70-8.

21. Matsunaga J, Lo M, Bulach DM, Zuerner RL, Adler B, Haake DA. Response of Leptospira interrogans to physiologic osmolarity: relevance in signaling the environment-to-host transition. Infect Immun 2007; 75:2864-74.

22. Choy HA, Kelley MM, Chen TL, Møller AK, Matsunaga J, Haake DA. Physiological osmotic induction of Leptospira interrogans adhesion: LigA and LigB bind extracellular matrix proteins and fibrinogen. Infect Immun 2007; 75:2441-50.

23. Lin YP, Chang YF. A domain of the Leptospira LigB contributes to high affinity binding of fibronectin. Biochem Biophys Res Commun 2007; 362:443-8.

24. Lin YP, Chang YF. The C-terminal variable domain of LigB from Leptospira mediates binding to fibronectin. J Vet Sci 2008; 9:133-44.

25. Lin YP, Raman R, Sharma Y, Chang YF. Calcium binds to leptospiral immunoglobulin-like protein, $\mathrm{LigB}$, and modulates fibronectin binding. J Biol Chem 2008; 283:25140-9.

26. Lin YP, Lee DW, McDonough SP, Nicholson LK, Sharma Y, Chang YF. Repeated domains of leptospira immunoglobulin-like proteins interact with elastin and tropoelastin. J Biol Chem 2009; 284:19380-91.

27. Lin YP, Greenwood A, Nicholson LK, Sharma Y, McDonough SP, Chang YF. Fibronectin binds to and induces conformational change in a disordered region of leptospiral immunoglobulin-like protein B. J Biol Chem 2009; 284:23547-57.

28. Lin YP, Greenwood A, Yan W, et al. A novel fibronectin type III module binding motif identified on C-terminus of Leptospira immunoglobulin-like protein, LigB. Biochem Biophys Res Commun 2009; 389:57-62.

29. Lin YP, McDonough SP, Sharma Y, Chang YF. The terminal immunoglobulin-like repeats of LigA and LigB of Leptospira enhance their binding to gelatin binding domain of fibronectin and host cells. PLoS One 2010; 5:e11301.

30. Barbosa AS, Abreu PA, Neves FO, et al. A newly identified leptospiral adhesin mediates attachment to laminin. Infect Immun 2006; 74: 6356-64.

31. Ramos CR, Abreu PA, Nascimento AL, Ho PL. A high-copy T7 Escherichia coli expression vector for the production of recombinant proteins with a minimal $\mathrm{N}$-terminal His-tagged fusion peptide. Braz J Med Biol Res 2004; 37:1103-9.

32. Jokiranta TS, Zipfel PF, Hakulinen J, et al. Analysis of the recognition mechanism of the alternative pathway of complement by monoclonal anti-factor $\mathrm{H}$ antibodies: evidence for multiple interactions between $\mathrm{H}$ and surface bound C3b. FEBS Lett 1996; 393:297-302. 
33. Oppermann M, Manuelian T, Józsi M, et al. The C-terminus of complement regulator factor $\mathrm{H}$ mediates target recognition: evidence for a compact conformation of the native protein. Clin Exp Immunol 2006; 144:342-52.

34. Kühn S, Zipfel PF. The baculovirus expression vector pBSV-8His directs secretion of histidine-tagged proteins. Gene 1995; 162:225-9.

35. de Paula PF, Barbosa JE, Junior PR, et al. Ontogeny of complement regulatory proteins - concentrations of factor $h$, factor $\mathrm{I}, \mathrm{c} 4 \mathrm{~b}$-binding protein, properdin and vitronectin in healthy children of different ages and in adults. Scand J Immunol 2003; 58:572-7.

36. Ferreira VP, Pangburn MK, Cortés C. Complement control protein factor $\mathrm{H}$ : the good, the bad, and the inadequate. Mol Immunol 2010; 47:2187-97.

37. Heinen S, Hartmann A, Lauer N, et al. Factor H-related protein 1 (CFHR-1) inhibits complement C5 convertase activity and terminal complex formation. Blood 2009; 114:2439-47.

38. Rossmann E, Kraiczy P, Herzberger P, et al. Dual binding specificity of a Borrelia hermsii-associated complement regulator-acquiring surface protein for factor $\mathrm{H}$ and plasminogen discloses a putative virulence factor of relapsing fever spirochetes. J Immunol 2007; 178: 7292-301.

39. Haupt K, Kraiczy P, Wallich R, Brade V, Skerka C, Zipfel PF. Binding of human factor $\mathrm{H}$-related protein 1 to serum-resistant Borrelia burgdorferi is mediated by borrelial complement regulator-acquiring surface proteins. J Infect Dis 2007; 196:124-33.

40. Haupt K, Reuter M, van den Elsen J, et al. The Staphylococcus aureus protein Sbi acts as a complement inhibitor and forms a tripartite complex with host complement factor $\mathrm{H}$ and C3b. PLoS Pathog 2008; 4:e1000250.

41. Kunert A, Losse J, Gruszin C, et al. Immune evasion of the human pathogen Pseudomonas aeruginosa: elongation factor Tuf is a factor $\mathrm{H}$ and plasminogen binding protein. J Immunol 2007; 179:2979-88.
42. Behnsen J, Hartmann A, Schmaler J, Gehrke A, Brakhage AA, Zipfel PF. The opportunistic human pathogenic fungus Aspergillus fumigatus evades the host complement system. Infect Immun 2008; 76:820-7.

43. Hammerschmidt S, Agarwal V, Kunert A, Haelbich S, Skerka C, Zipfel PF. The host immune regulator factor $\mathrm{H}$ interacts via two contact sites with the PspC protein of Streptococcus pneumoniae and mediates adhesion to host epithelial cells. J Immunol 2007; 178:5848-58.

44. Pandiripally V, Wei L, Skerka C, Zipfel PF, Cue D. Recruitment of complement factor $\mathrm{H}$-like protein 1 promotes intracellular invasion by group A streptococci. Infect Immun 2003; 71:7119-28.

45. Losse J, Zipfel PF, Józsi M. Factor $\mathrm{H}$ and factor H-related protein 1 bind to human neutrophils via complement receptor 3, mediate attachment to Candida albicans, and enhance neutrophil antimicrobial activity. J Immunol 2010; 184:912-21.

46. Patarakul K, Lo M, Adler B. Global transcriptomic response of Leptospira interrogans serovar Copenhageni upon exposure to serum. BMC Microbiol 2010; 10:31.

47. Silva EF, Medeiros MA, McBride AJ, et al. The terminal portion of leptospiral immunoglobulin-like protein LigA confers protective immunity against lethal infection in the hamster model of leptospirosis. Vaccine 2007; 25:6277-86.

48. Faisal SM, Yan W, Chen CS, Palaniappan RU, McDonough SP, Chang YF. Evaluation of protective immunity of Leptospira immunoglobulin like protein A (LigA) DNA vaccine against challenge in hamsters. Vaccine 2008; 26:277-87.

49. Faisal SM, Yan W, McDonough SP, Chang YF. Leptospira immunoglobulin-like protein A variable region (LigAvar) incorporated in liposomes and PLGA microspheres produces a robust immune response correlating to protective immunity. Vaccine 2009; 27:378-87.

50. Yan W, Faisal SM, McDonough SP, et al. Immunogenicity and protective efficacy of recombinant Leptospira immunoglobulin-like protein B (rLigB) in a hamster challenge model. Microbes Infect 2009; 11:230-7. 